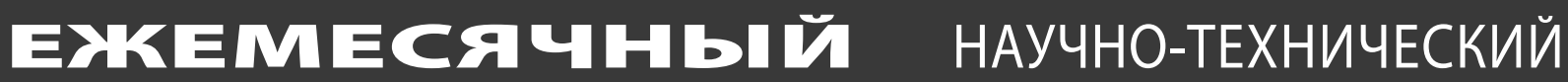
И ПРОИЗВОДСТВЕННО-ЭКОНОМИЧЕСКИЙ ХКУРНАЛ
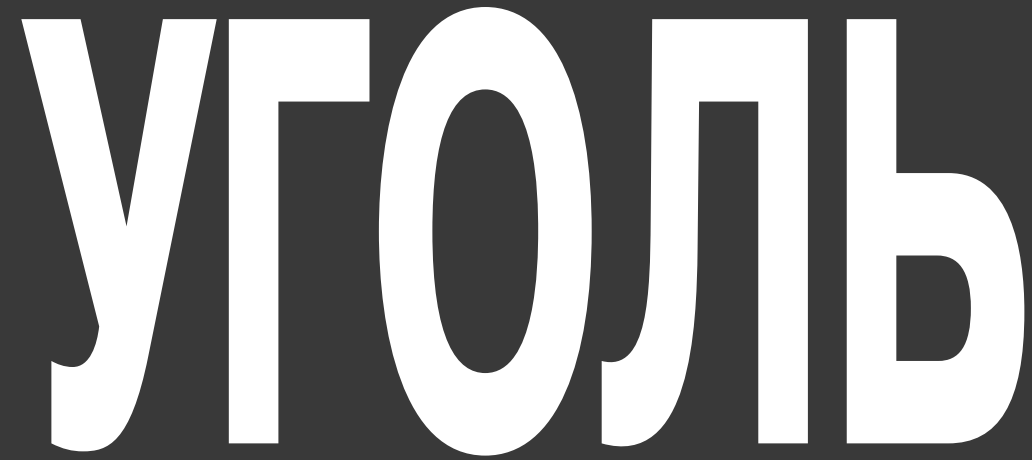

МИНИСТЕРСТВА ЭНЕРГЕТИКИ
РОССИЙСКОЙ ФЕДЕРАЦИИ
WWW.UGOLINFO.RU

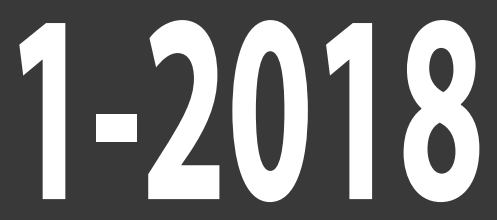

\title{
Дизельные
}

PERFORMANCE THROUGH INNOVATION

\section{и электрические}

\section{HacocHble устаHовkи PIONEER PUMP}

- ПропзводительНость मо $11000 \mathrm{~m}^{3}$ /4, напор свыше $200 \mathrm{M}$; - Kopotkий срок Поставки, склад запцастей в России
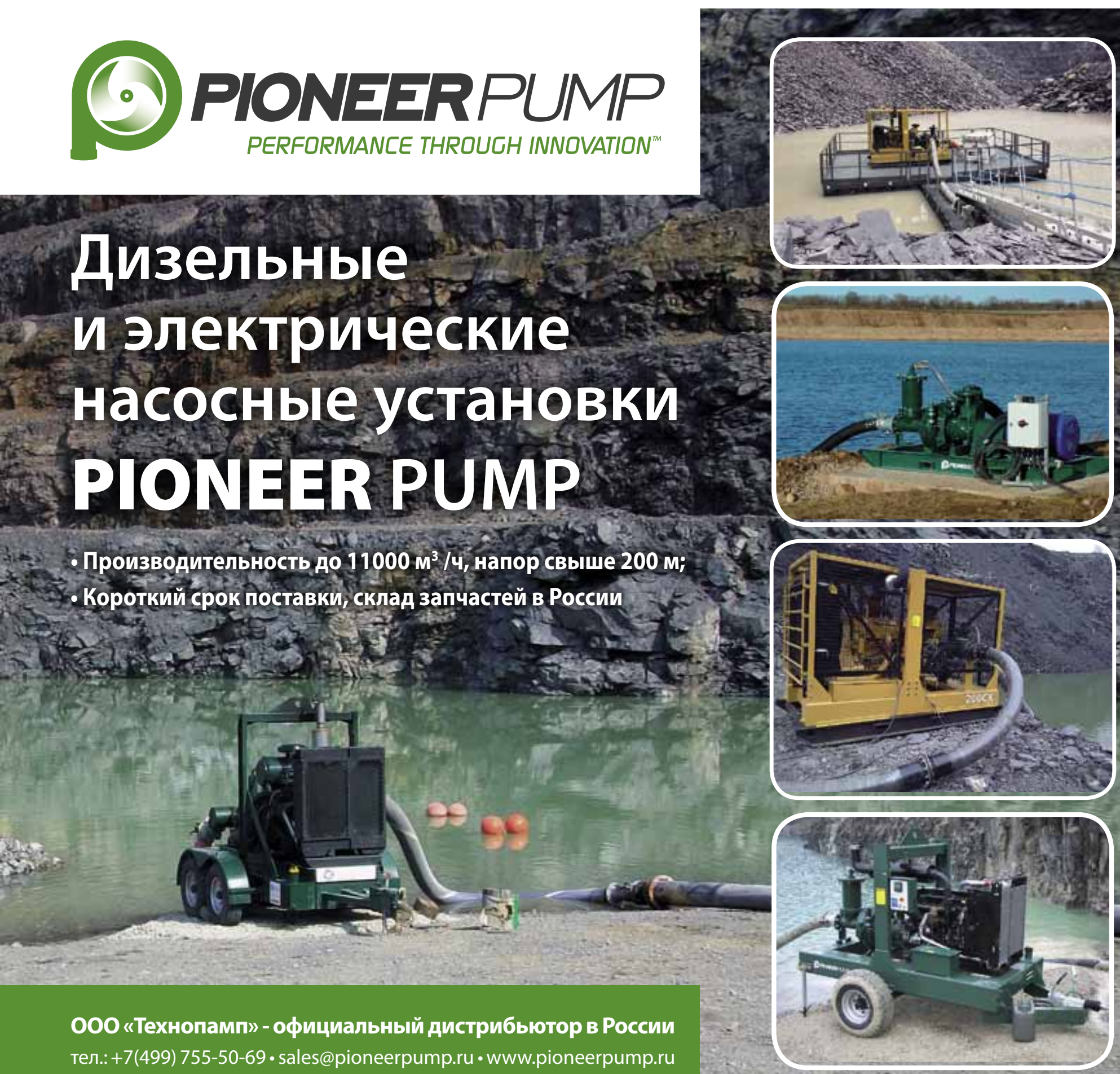


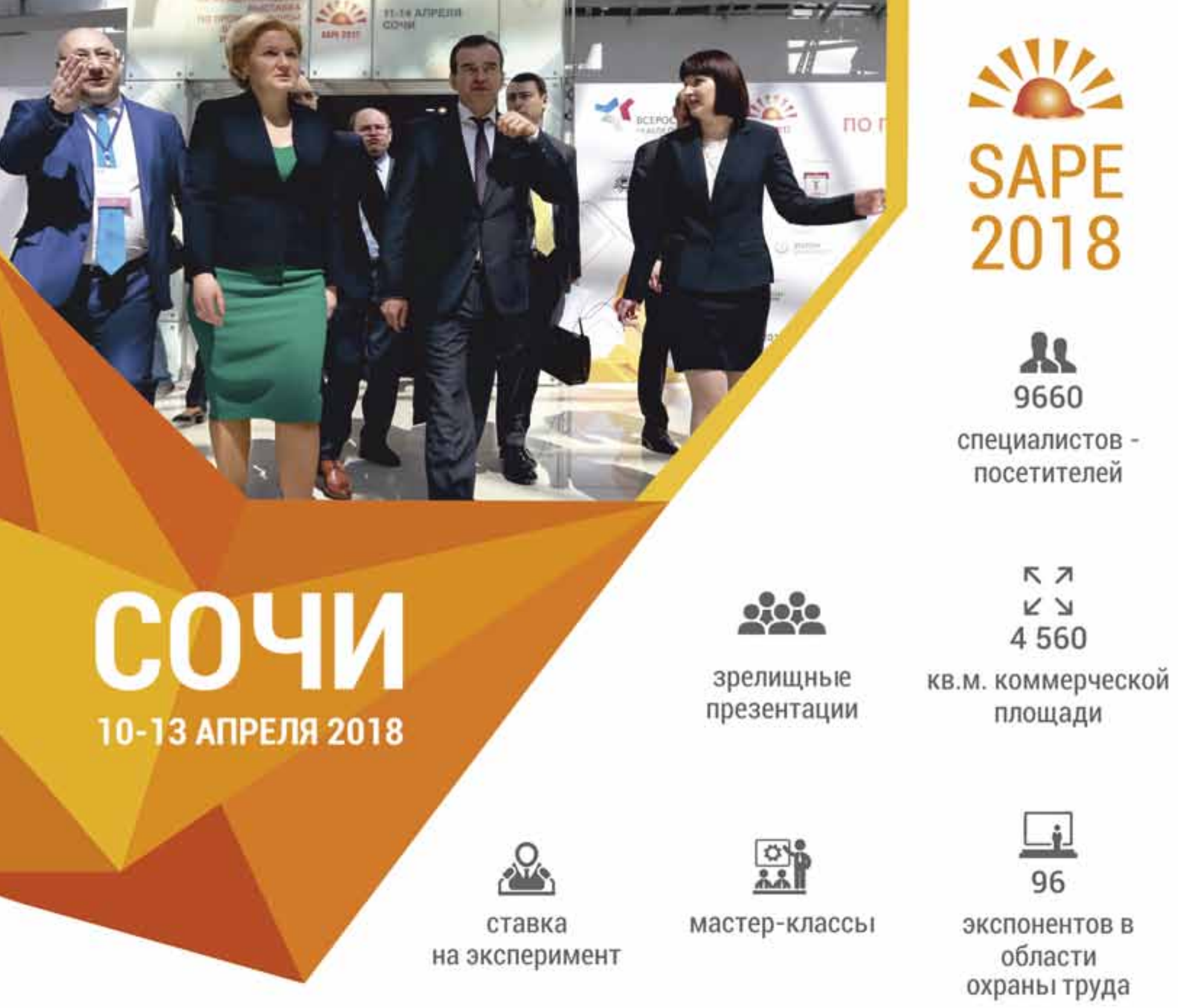

\section{IX МЕЖДУНАРОДНАЯ ВЫСТАВКА ПО ПРОМЬШЛЕННОЙ БЕЗОПАСНОСТИ И ОХРАНЕ ТРУДА} re 
Главный редактор ЯНОВСКИЙ А.Б.

Заместитель министра энергетики

Российской Федерачии,

доктор экон. наук

\section{Зам. главного редактора}

ТАРАЗАНОВ И.Г.

Генеральный директор

ООО «Редакция журнала «Уголь»,

горный инженер, чл.-корр. РАЭ

\section{РЕДАКЦИОННАЯ КОЛЛЕГИЯ}

АРТЕМЬЕВ В.Б, Әоктор ТеХН. Наук ВЕРЖАНСКИЙ А.П.,

доктор техн. наук, профессор

ГАЛКИН В.А., доктор техн. наук, профессор ЗАЙДЕНВАРГ В.Е.,

доктор техн. наук, профессор

ЗАХАРОВ В.Н., ЧЛ.-КОрр. РАН,

Әоктор техн. Наук, профессор

КОВАЛЬЧУК А.Б.,

доктор техн. наук, профессор

ЛИТВИНЕНКО В.С.,

доктор техн. наук, профессор

МАЛЫШЕВ Ю.Н., академИК РАН,

доктор техн. наук, профессор

МОХНАЧУК И.И., КаНӘ. эКОН. НаУК

МОЧАЛЬНИКОВ С.В., Канд. эКОН. Наук

ПЕТРОВ И.В., доктор эКон. наук, профессор

попов В.Н., доктор экон. наук, профессор

ПОТАПОВ В.П.,

доктор техн. наук, профессор

ПучкОВ л.А., чл.-корр. РАН,

доктор техн. наук, профессор

РОЖков А.А., доктор экон. наук, профессор

РЫБАК Л.В., доктор экон. наук, профессор

СКРЫЛЬ А.И., горный инженер

СУСЛОВ В.И., чЛ.-корр. РАН, доктор экон.

наук, профессор

ЩАДОВ В.М., доктор техн. наук, профессор ЩУКИН В.К., доктор экон. наук

ЯКОВЛЕВ Д.В., доктор техн. наук, профессор

Иностранные члены редколлегии

Проф. Гюнтер АПЕЛЬ,

доктор техн. наук, Германия

Проф. Карстен ДРЕБЕНШТЕДТ,

доктор техн. наук, Германия

Проф. Юзеф дУБИНьСКИ,

доктор техн. наук, чл.-корр. Польской

академии наук, Польша

Сергей НИКИШИЧЕВ, комп. лицо FIMMM,

канд. экон. наук, Великобритания, Россия,

страны СНГ

Проф. Любен ТОТЕВ,

доктор наук, Болгария

๔. «Уголь», 2018

\section{ЕЖЕМЕСЯЧНЫЙ НАУЧНО-ТЕХНИЧЕСКИЙ} И ПРОИЗВОДСТВЕННО-ЭКОНОМИЧЕСКИЙ ЖУРНАЛ

Основан в октябре 1925 года

\section{УЧРЕДИТЕЛИ}

МИНИСТЕРСТВО ЭНЕРГЕТИКИ

РОССИЙСКОЙ ФЕДЕРАЦИИ

РЕДАКЦИЯ ЖУРНАЛА «УГОЛЬ»

ЯHBAPb

$1-2018 / 1102 /$

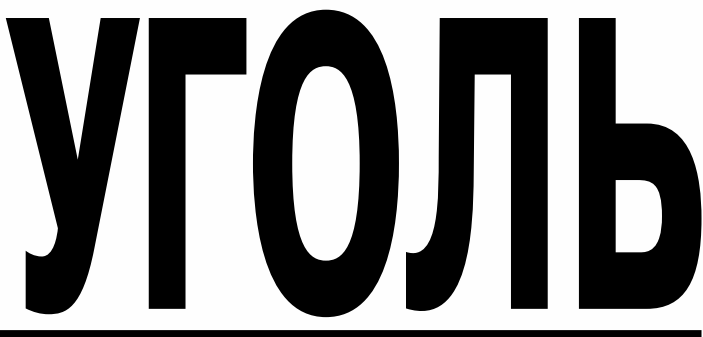

\section{СОДЕРЖАНИЕ}

\section{ОРГАНИЗАЦИЯ ПРОИЗВОДСТВА}

Неделя горняка - 2018

Карпов А.Н., Буйницкий А.И., Ошаров А.В., Килин Ю.А., Лапаева 0.А.

Деятельность руководителя предприятия: структура работы,

факторы, критерии оценки результатов

Жабин А.Б., Поляков А.В., Аверин Е.А.

Краткий анализ проблем и путей решения при обеспечении

горнодобывающего предприятия современными техническими средствами

ведения горных работ

$\mathrm{A} 0$ «СУЭК»

СУЭК первой в России и странах СНГ получила сертификат соответствия стандарту ISO 55001 «Менеджмент активов»

\section{АНАЛИТИЧЕСКИЙ ОБЗОР}

Таразанов И.Г.

Итоги работы угольной промышленности России

за январь-сентябрь 2017 года

\section{БЕЗОПАСНОСТЬ}

Ким М.Л., Родичев А.С., Певзнер Л.Д., Платонов А.К.

0 возможности использования мобильных робототехнических летательных аппаратов при выполнении оперативного плана ликвидации аварии на шахтах 34

СУЭК и АМЗ «ВЕНТПРОМ» обсудили аэрологическую безопасность угольных шахт

Качурин Н.М., Ефимов В.И., Стась Г.В., Качурин А.Н.

Прогноз радоновой опасности и расчет количества воздуха

для проветривания очистных участков по радоновому фактору

Черданцев С.В., Ли Х.У., Филатов Ю.М., Шлапаков П.А.

Влияние параметров грубодисперсных пылегазовоздушных смесей

на время их выгорания в горных выработках угольных шахт 44

\section{ИННОВАЦИИ}

Плакиткин Ю.А., Плакиткина Л.С.

Мировой инновационный проект «Индустрия-4.0»- возможности применения

в угольной отрасли России. 3. Систематизация основных элементов проекта

«Индустрия-4.0 по базовым процессам горного производства

(Окончание. Начало см. журналы «Уголь», №10-2017, с. 44-50, №11-2017, с. 46-53)

\section{ХРОНИКА}

$\mathrm{A} 0$ «СУЭК»

Информационные сообщения 
ООО «РЕДАКЦИЯ ЖУРНАЛА «УГОЛЬ»

119049, г. Москва,

Ленинский проспект, д. 2А, офис 819

Тел.: +7 (499) 237-22-23

E-mail:ugol1925@mail.ru

E-mail:ugol@land.ru

Генеральный директор

Игорь ТАРАЗАНОВ

Ведущий редактор

Ольга ГЛИНИНА

Научный редактор

Ирина КОЛОБОВА

Менеджер

Ирина ТАРАЗАНОВА

Ведущий специалист

Валентина ВОЛКОВА

ЖУРНАЛ ЗАРЕГИСТРИРОВАН

Федеральной службой по надзору

в сфере связи и массовых коммуникаций.

Свидетельство о регистрации

средства массовой информации

ПИ № ФС77-34734 от 25.12.2008

ЖУРНАЛ ВКЛЮЧЕН

В Перечень ВАК Минобразования и науки РФ

(в международные реферативные базы

данных и системы цитирования) -

по техническим и экономическим наукам

Пятилетний импакт-фактор РИНЦ

без самоцитирования - 0,315

ЖУРНАЛ ПРЕДСТАВЛЕН

в Интернете на вэб-сайте

www.ugolinfo.ru www.ugol.info

и на отраслевом портале «РОССИЙСКИЙ УГОЛЬ»

wWw.rosugol.ru

информационный партнер журнала - УгОЛьНЫЙ ПОРТАЛ

\section{www.coal.dp.ua}

НАД НОМЕРОМ РАБОТАЛИ:

Ведущий редактор О.И. ГЛИНИНА

Научный редактор И.М. КОЛОБОВА

Корректор В.В. ЛАСТОВ

Компьютерная верстка Н.И. БРАНДЕЛИС

Подписано в печать 26.12.2017.

Формат 60х90 1/8.

Бумага мелованная. Печать офсетная.

Усл. печ. л. 11,0+ обложка.

Тираж 4700 экз.

Тиражэл. версии 1600 экз.

Общий тираж 6500 экз.

Отпечатано:

ООО «РОЛИКС

117218, г. Москва, ул. Кржижановского, 31

Тел.: (495) 661-46-22;

www.roliksprint.ru

Заказ № 44415

Журнал в App Store $n$ Google Play

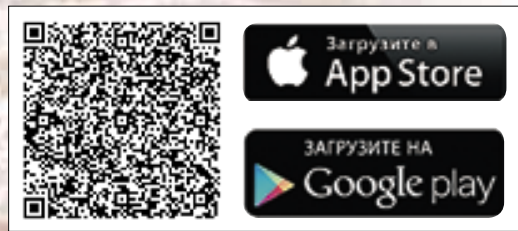

๑ ЖУРНАЛ «УГОЛЬ», 2018

\section{ГЕОЛОГИЯ}

Гриб Н.Н., Кузнецов П.Ю.

Прогнозирование физико-механических свойств углевмещающих пород на основе данных геофизических исследований скважин и математического аппарата Марковской нелинейной статистики

$$
\text { экология }
$$

Досмухамедов Н.К., Жолдасбай Е.Е., Каплан В.А.

Технология очистки отходящих газов ТЭС от серы: регенерация карбонатно-сульфатного расплава монооксидом углерода

Зеньков И.В., Барадулин И.М.

Исследование условий формирования и характеристик лесных экосистем в отработанных щебеночных карьерах в Красноярском крае

ЮБИЛЕИ

Дрижд Николай Александрович (к 90-летию со дня рождения) 85

Мохначук Иван Иванович (к 60-летию со дня рождения) 86

Смирнов Олег Владимирович (к 60-летию со дня рождения) 87

Грибин Юрий Георгиевич (к 80-летию со дня рождения) 88

Список реклам:

\begin{tabular}{|c|c|c|c|}
\hline & & & \\
\hline Выставка SAPE-2018 & 2-я обл. & НПП Завод МДУ & 50 \\
\hline Назаровское ГМНУ (СУЭК) & 3-я обл. & Выставка Уголь СНГ & 61 \\
\hline Выставка MiningWorld Russia & 4-я обл. & Выставка ГОРПРОМЭКСПО & 63 \\
\hline
\end{tabular}

\section{Журнал «Уголь» входит \\ в международные реферативные базы данных и систем цитирования \\ SCOPUS, GeoRef, Chemical Abstracts}

Журнал «Уголь» является партнером CROSSREF

Редакция журнала «Уголь» является членом Международной ассоциации по связям издателей / Publishers International Linking Association, Inc. (PILA).

Всем научным статьям журнала присваиваются Digital Object Identifier (DOI).

\section{Журнал «Уголь» является партнером EBSCO}

Редакция журнала «Уголь» имеет соглашение с компанией EBSCO Publishing, Inc. (США). Bce публикации журнала «Уголь» с 2016 г. входят в базуданных компании EBSCO Publishing (www.ebsco.com), предоставляющей свою базу данных для академических библиотек по всему миру. EBSCO имеет партнерские отношения с библиотеками на протяжении уже более 70 лет, обеспечивая содержание исследований качества, мощные технологии поиска и интуитивные платформы доставки.

\section{Журнал «Уголь» представлен в «КиберЛенинке»}

Электронная научная библиотека «КиберЛенинка» (CYBERLENINKA) входит в mon-10 мировых электронных хранилищ научных публикачий и построена на парадигме открытой науки (Open Science), основными задачами которой являются популяризация науки и научной деятельности, общественный контроль качества научных публикаций, развитие междисциплинарных исследований и повышение цитируемости российской науки. Это третья в мире электронная библиотека по степени видимости материалов в Google Scholar.

Подписные индексы:

- Каталог Роспечати «Газеты. Журналы» - 71000, 71736, 73422

- Объединенный каталог «Пресса России» - 87717, 87776, 987717

- Каталог «Почта России» - П3724

- Каталог «Российской прессы» - 11538

- Каталог «Урал-Пресс» - 71000; 007097; 009901 
UGOL' / RUSSIAN COAL JOURNAL

UGOL' JOURNAL EDITORIAL BOARD

Chief Editor

YANOVSKY A.B., Dr. (Economic), Ph.D.

(Engineering), Deputy Minister of Energy

of the Russian Federation, Moscow,

107996, Russian Federation

Deputy Chief Editor

TARAZANOV I.G., Mining Engineer, Moscow,

119049, Russian Federation

Members of the editorial council:

ARTEMIEV V.B., Dr. (Engineering),

Moscow, 115054, Russian Federation

VERZHANSKY A.P., Dr. (Engineering), Prof.,

Moscow, 125009, Russian Federation

GALKIN V.A., Dr. (Engineering), Prof.,

Chelyabinsk, 454048, Russian Federation

ZAIDENVARG V.E., Dr. (Engineering), Prof.,

Moscow, 119019, Russian Federation

ZAKHAROV V.N., Dr. (Engineering), Prof.,

Corresp. Member of the RAS,

Moscow, 111020, Russian Federation

KOVALCHUK A.B., Dr. (Engineering), Prof.,

Moscow, 119019, Russian Federation

LITVINENKO V.S., Dr. (Engineering), Prof.,

Saint Petersburg, 199106, Russian Federation

MALYSHEV Yu.N., Dr. (Engineering), Prof.,

Acad. of the RAS, Moscow, 125009, Russian

Federation

MOKHNACHUK I.I., Ph.D. (Economic),

Moscow, 109004, Russian Federation

MOCHALNIKOV S.V., Ph.D. (Economic),

Moscow, 107996, Russian Federation

PETROV I.V., Dr. (Economic), Prof.,

Moscow, 119071, Russian Federation

POPOV V.N., Dr. (Economic), Prof.,

Moscow, 119071, Russian Federation

POTAPOV V.P., Dr. (Engineering), Prof.,

Kemerovo, 650025, Russian Federation

PUCHKOV L.A., Dr. (Engineering), Prof.,

Corresp. Member of the RAS, Moscow, 119049,

Russian Federation

ROZHKOV A.A., Dr. (Economic), Prof.,

Moscow, 119071, Russian Federation

RYBAK L.V., Dr. (Economic), Prof.,

Moscow, 119034, Russian Federation

SKRYL' A.I., Mining Engineer,

Moscow, 119049, Russian Federation

SUSLOV V.I., Dr. (Economic), Prof., Corresp.

Member of the RAS, Novosibirsk, 630090, Russian

Federation

SHCHADOV V.M., Dr. (Engineering), Prof.,

Moscow, 119034, Russian Federation

SHCHUKIN V.K., Dr. (Economic),

Ekibastuz, 141209, Republic of Kazakhstan

YAKOVLEV D.V., Dr. (Engineering), Prof.,

Saint Petersburg, 199106, Russian Federation

Foreign members of the editorial council:

Prof. Guenther APEL, Dr.-Ing.,

Essen, 45307, Germany

Prof. Carsten DREBENSTEDT, Dr. (Engineering),

Freiberg, 09596, Germany

Prof. Jozef DUBINSKI, Dr. (Engineering), Corresp.

Member PAS, Katowice, 40-166, Poland

Sergey NIKISHICHEV, FIMMM, Ph.D. (Economic),

Moscow, 125047, Russian Federation

Prof. Luben TOTEV, Dr., Sofia, 1700, Bulgaria

Ugol' Journal Edition LLC

Leninsky Prospekt, 2A, office 819

Moscow, 119049, Russian Federation

Tel.: +7 (499) 237-2223

E-mail: ugol1925@mail.ru

www.ugolinfo.ru

๑) Ugol' - Russian Coal Journal, 2018
MONTHLY JOURNAL, THAT DEALS WITH SCIENTIFIC, TECHNICAL, INDUSTRIAL AND ECONOMIC TOPICS

Established in October 1925

FOUNDERS

MINISTRY OF ENERGY

THE RUSSIAN FEDERATION,

UGOL' JOURNAL EDITION LLC

JANUARY

$1^{\prime} 2018$

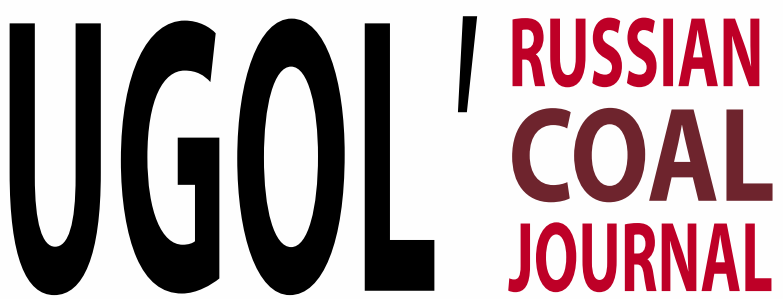

CONTENT

\section{PRODUCTION SETUP}

Miner's Week - 2018 4

Karpov A.N., Buinitsky A.I., Osharov A.V., Kilin Yu.A., Lapaeva 0.A.

Enterprise Manager performance: activity structure, factors, results assessment criteria 7

ECONOMIC OF MINING

Zhabin A.B., Polyakov A.V., Averin E.A.

$A$ brief analysis of problems and solutions when ensuring the mining enterprise

with modern equipment

ANALYTICAL REVIEW

Tarazanov I.G.

Russia's coal industry performance for January - September, 2017

18

SAFETY

Kim M.L., Rodichev A.S., Pevzner L.D., Platonov A.K.

Possibility of using robotic flying systems for solving accident liquidation

operating plan in the mine

SUEK and AMZ "Ventprom" discussed coal mines aerologic safety

39

Kachurin N.M., Efimov V.I., Stas G.V., Kachurin A.N.

Forecasting radon danger and calculating quantity of air for ventilation

of production faces by radon factor

Cherdantsev S.V., Lee Kh.U., Filatov Yu.M., Shlapakov P.A.

Influence of parameters of the roughly dispersed dust gas mixtures

at the time of their burn-out in mine workings of coal mines 44

INNOVATIONS

Plakitkin Yu.A., Plakitkina L.S.

The Industry-4.0 global innovation project's potential for the coal industry of Russia.

3. "Industry $-4.0^{\prime \prime}$ key components alignment in accordance with basic mining processes 51

CHRONICLE

"SUEK", JSC

Information messages

GEOLOGY

Grib N.N., Kuznetsov P.Yu.

Forecasting physical and mechanical properties of coal-bearing rocks based

on the well logging data and mathematical tool of Markov non-linear statistics 68

ECOLOGY

Dosmukhamedova N.K., Zholdasbay E.E., Kaplan V.A.

Technology of waste gas purification from TPP from sulfur:

Regeneration of carbonate-sulfate melt carbon monoxide

74

Zenkov I.V., Baradulin I.M.

Study results of vegetation emergence and formation in depleted crushed

stone quarries in Krasnoyarsk Krai

ANNIVERSARIES

Drizhd Nikolay Aleksandrovich (to a 90-anniversary from birthday)

Mokhnachuk Ivan Ivanovich (to a 60-anniversary from birthday)

Smirnov Oleg Vladimirovich (to a 60-anniversary from birthday)

Gribin Yury Georgiyevich (to a 80-anniversary from birthday) 

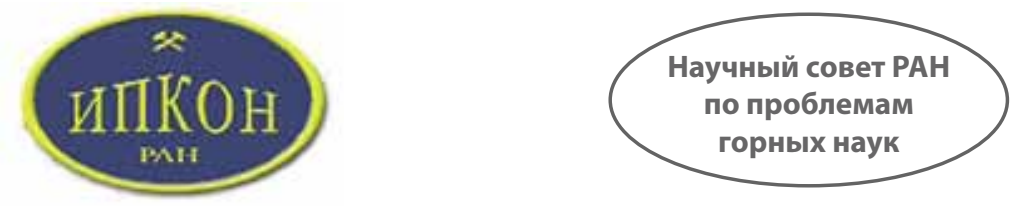

\section{НЕДЕЛЯ ГОРНЯКА - 2018}

С 29 января по 2 февраля 2018 г. в Москве, в Горном институте НИТУ «МИСиС» пройдет XXVI Международный научный симпозиум «Неделя горняка - 2018». В этом году «Неделя горняка» дает старт ряду мероприятий в рамках празднования юбилея образования Московской горной академии.

Организаторами форума выступают Национальный исследовательский технологический университет «МИСиС», Институт проблем комплексного освоения недр РАН, Научный совет РАН по проблемам горных наук.

Международный научный симпозиум «Неделя горняка» на протяжении четверти века является главной площадкой в России по обсуждению актуальных проблем горнодобывающей промышленности. Симпозиум объединяет представителей бизнеса, власти, научного сообщества из разных государств для обсуждения актуальных и основополагающих проблем современной горной науки и бизнеса.

За годы проведения в работе симпозиума приняли участие специалисты более чем из 40 стран, представители тысяч компаний и сотен университетов.

В этом году в рамках работы симпозиума пройдут: пленарное заседание, семинары по научным направлениям: заседание Coвета Федерального учебно-методического объединения в системе высшего образования по укрупненной группе специальностей и направлений подготовки - прикладная геология, горное дело, нефтегазовое дело и геодезия, заседание Научного совета РАН по проблемам использования взрывов в народнохозяйственных целях, заседание Научного совета РАН по проблемам горных наук, а также ряд презентаций и круглых столов.

Участники и гости симпозиума смогут ознакомиться с научными лабораториями, центрами и кафедрами горно-металлургического направления, геологическим музеем.

\section{НАУЧНЫЕ НАПРАВЛЕНИЯ СИМПОЗИУМА И СЕССИИ:}

Инженерная геология и маркшейдерское дело;

Инженерная геофизика, геомеханика, геодинамика;

Геотехнология подземная и открытая;

Безопасность горного производства;

Охрана окружающей среды в промышленных регионах;

Роботизированные технологии и механизация горных предприятий; Обогащение и глубокая переработка полезных ископаемых;

Информационные технологии в горном деле;

Проектирование и строительство подземных промышленных объектов;

Освоение новых источников минерального сырья;

Управление и экономика на горных предприятиях.

Рабочие языки симпозиума: русский / английский.

Доклады участников будут опубликованы: (по желанию авторов)

в Горном информационно-аналитическом бюллетене в течение года. Примечание: плата за публикацию статей не взимается; приоритет по срокам публикации отдается статьям очных участников симпозиума.

\section{КОНТАКТЫ ОРГКОМИТЕТА:}

Куратор деловой программы:

Королева Валентина Николаевна, тел.:+7 (499) 230-27-51

Куратор деловой программы и финансовых операций: Липина Александра Валерьевна, тел.: +7 (903) 105-08-13, e-mail: minersweek@misis.ru 


\section{СУЭК преодолела 100-миллионную планку \\ годовой добычи}

\begin{abstract}
9 декабря 2017 г. предприятия $\mathrm{AO}$ «Cuбирская угольная энергетическая компания» (СУЭК) преодолели 100-миллионную планку годовой добычи.
\end{abstract}

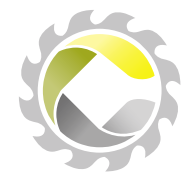

Свой вклад в достижение этого результата внесли угледобывающие предприятия всех региональных производственных объединений СУЭК: предприятия Приморья добыли 3,3 млн т, Ургала - 6 млн т, Бурятии - 13 млн т,

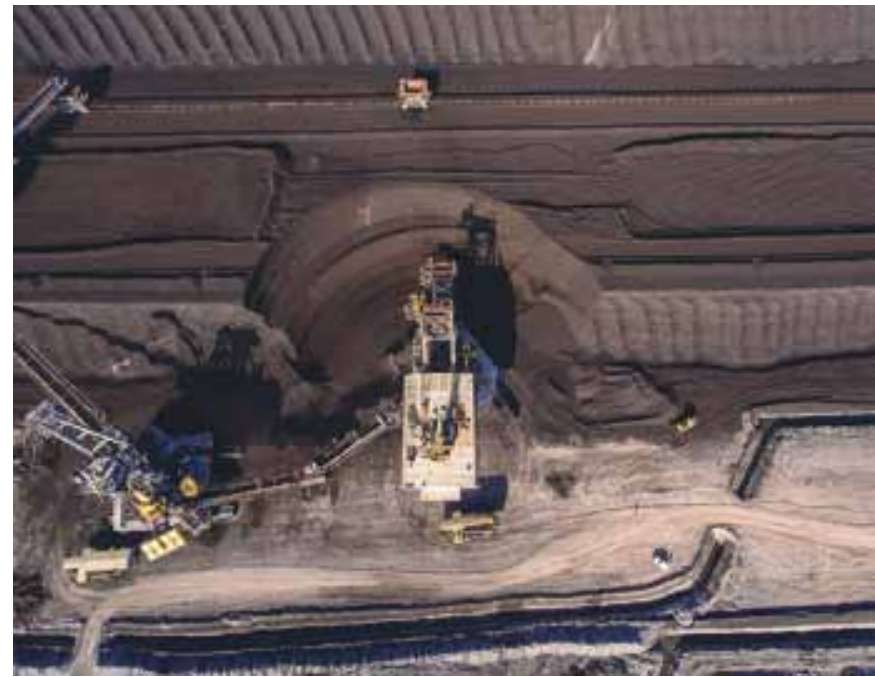

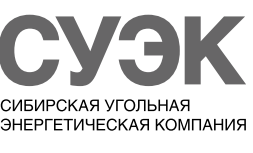

Забайкалья - 4,7 млн т, Красноярского края - 25,1 млн т, Хакасии - 12,1 млн т, Кузбасса - 35,8 млн т.

С начала 2017 г. коллективами предприятий СУЭК установлено 17 мировых рекордов: 8 мировых рекордов - по экскавации горной массы; 7 мировых рекордов - по однозаходному и многозаходному бурению скважин; 2 мировых рекорда - по очистной добыче угля.

Мировые достижения по экскавации горной массы для различных типов экскаваторов составили: HITACHI EX-1200 - 381 тыс. $\mathrm{M}^{3} / \mathrm{Mec}$; KOMATSU PC- 1250 - 459 тыс. $\mathrm{M}^{3} / \mathrm{Mec}^{\circ} ;$ KOMATSU PC-

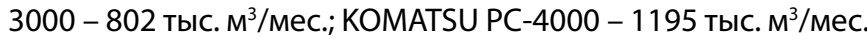

Рекорды по бурению скважин различными типами буровых станков достигли следующих показателей: PitViper-275 40310 пог. м/мес.; DML-1200 - 42041 пог. м/мес.; PitViper-271 52592 пог. м/мес.

В мае 2017 г. на шахте имени В.Д. Ялевского (пласт 50) установлен мировой рекорд по добыче угля из одного очистного забоя - 1 млн 407 тыс. т за месяц. В июле 2017 г. коллектив упомянутого выше предприятия обновил собственный мировой рекорд, добыв из одного очистного забоя 1 млн 567 тыс. т за месяц.

Напомним, что впервые в истории угольной отрасли России 100-миллионная планка добычи одним производственным объединением была преодолена год назад - в 2016 г. предприятия СУЭК добыли в общей сложности 105,4 млн т угля.

\section{Вклад предприятий СУЭК Красноярского края В общую копилку СУЭК по преодолению 100-миллионной планки добычи угля}

$\mathrm{AO}$ «Сибирская угольная энергетическая компания» (СУЭК) преодолело производственный рубеж в 100 миллионов тонн угля с начала года. Вклад предприятий Красноярского края в общий объем - 25 процентов.

Красноярский край является вторым по объемам угледобычи регионом после признанного лидера отрасли - Кеме-

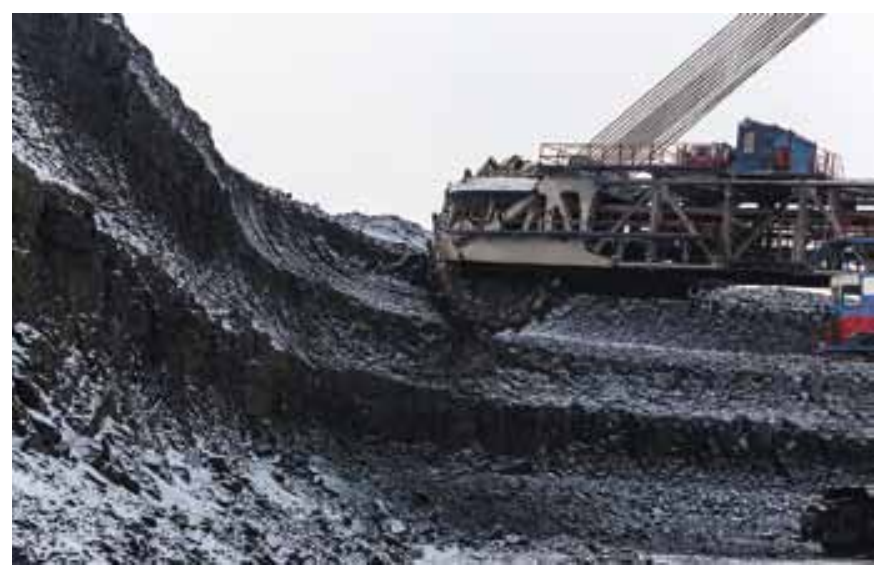

ровской области. На текущий момент расположенные здесь разрезы «Бородинский имени М.И. Щадова», «Березовский» и «Назаровский» отгрузили потребителям свыше 25 млн тугля.

Значительный вклад в общий объем добычи - более 18 млн т - внес крупнейший в России Бородинский разрез. Предприятие также почти на месяц раньше срока рапортовало о досрочном выполнении годового производственного плана. До конца календарного года разрез планировал отгрузить еще около 1,5 млн т угля.

Определенных успехов добились Березовский и Назаровский разрезы: 6 декабря, объявленного в СУЭК Днем повышенной угледобычи, предприятия достигли максимальных за свою историю суточных показателей. «Сегодня мы не сбавляем темпов работы и готовы к любым нагрузкам», подчеркнул генеральный директор АО «СУЭК-Красноярск» Андрей Федоров.

С начала года коллективами предприятий СУЭК установлено множество рекордов, в том числе 17 мирового уровня, прежде всего на вскрышных работах, а также на однозаходном и многозаходном бурении скважин, очистной добыче угля. 


\section{Деятельность руководителя предприятия:}

\section{структура работы, факторы, критерии оценки результатов}

DOI: http://dx.doi.org/10.18796/0041-5790-2018-1-7-12

В статье представлены основные результаты работы группы руководителей ПЕ, которые в рамках конференции 26-30 июня 2017 г. «Промышленная безопасность, экология, охрана и медицина труда в СУЭК. Итоги 2016 года. Задачи 2017 года» прорабатывали возможности повышения эффективности своей деятельности. При оценке участниками группы своей деятельности выявлено, что функции развития производственной системы с целью обеспечения жизнеспособности предприятия в условиях предстоящего ухудшения ситуации на мировом рынке угля уделяется недостаточно времени и внимания. Для повышения уровня жизнеспособности предприятия и ценности деятельности как директора, так и персонала целесообразно освоить функцию управления непрерывным развитием предприятия. Ключевые слова: руководитель, деятельность, структура, факторы, критерии оценки, результат, полезная работа, бесполезная работа, вредная работа, ченность руководителя, жизнеспособность.

«В управлении есть последовательность: сначала наведи порядок в близком, потом наведи порядок в далеком; сначала наведи порядок в распоряжениях, потом наведи порядок в наказаниях; сначала наведи порядок среди сильных, потом наведи порядок среди слабых; сначала наведи порядок в большом, потом наведи порядок в малом; сначала наведи порядок в своей жизни, потом приводи к порядку других.»

Китайский полководец Чжугэ Лян (181-234)

\section{ВВЕДЕНИЕ}

Сегодня практически у любого руководителя имеются проблемы повышения эффективности своей деятельности, определяемые не его личностными качествами или конкретной производственной ситуацией, а носящие принципиальный, системный характер. В большей мере эти затруднения универсальны и характерны для сложившейся современной российской практики управления предприятиями, организациями, компаниями [1, 2].

Для изменения такого положения, по мнению авторов и участников семинара, недостаточно отдельных улучшений в области менеджмента, применения модного зарубежного управленческого инструментария - необходимо разбираться с тем, что и как делает руководитель, а главное, с какой целью [3, 4].

Сцелью поиска резервов повышения эффективности деятельности руководителя авторами была проведена оценка ее структуры, предложены критерии и факторы, влия-

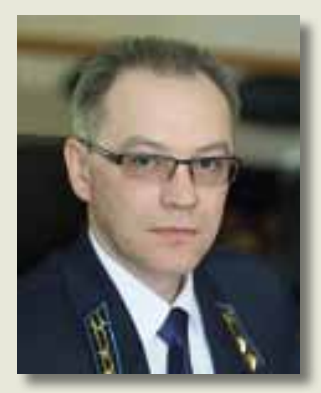

КАРПОВ Андрей Николаевич Управляющий филиалом $A О$ «СУЭК-Красноярск» «Бородинское погрузочнотранспортное управление», 663981, г. Бородино, Россия, e-mail:KarpovAN@suek.ru

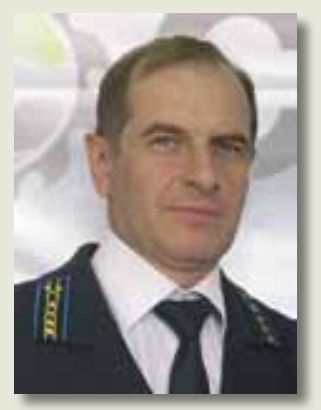

\section{БУЙницкий}

\section{Александр Иванович}

Первый заместитель генерального директора АО «Разрез Березовский», 662305, г. Шарыпово, Россия, e-mail:BujnitskijAl@suek.ru

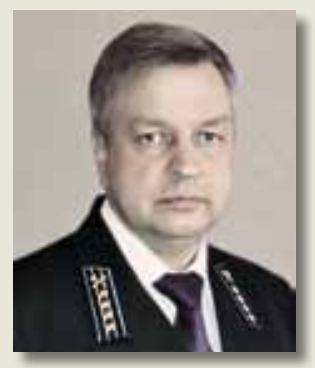

\section{ОШАРОВ}

Алексей Владимирович

Генеральный директор

АО «Разрез Изыхский»,

655650, с. Белый яр,

Республика Хакасия, Россия, e-mail: OsharovAV@suek.ru

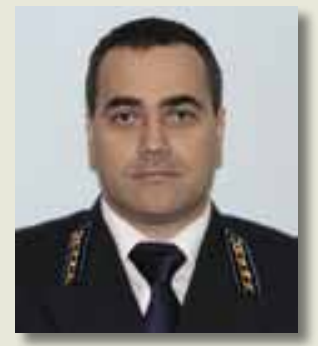

\section{КИЛИН Юрий Алексеевич}

Канд. техн. наук, первый заместитель генерального директора АO «Разрез Назаровский», 662200 , г. Назарово, Россия, e-mail:KilinYuA@suek.ru

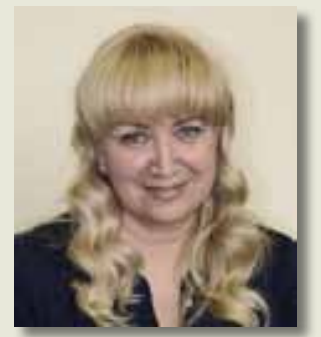

\section{ЛАПАЕВА}

\section{Оксана Анатольевна}

Канд. экон. наук, старший научный сотрудник Челябинского филиала Института горного дела УрО РАН, 454048, г. Челябинск, Россия, e-mail: lapaeva@yandex.ru 
ющие на результаты деятельности. Проработана и предложена более эффективная структура деятельности, переход к которой позволяет улучшить связи и отношения в цепочке «руководитель ↔ подчиненный», на этой основе повысить ценность и руководителя, и персонала $[5,6,7]$.

\section{ДЕЯТЕЛЬНОСТЬ РУКОВОДИТЕЛЯ}

Деятельность современного руководителя протекает в сложных, противоречивых, быстро меняющихся условиях. Высокий темп изменений в жизни и на производстве, необходимость оперативного принятия важных управленческих решений в условиях дефицита времени и информации, наличие кризисных ситуаций различной природы - эти и многие другие факторы предъявляют повышенные требования к личностным и профессиональным характеристикам руководителей, набору их компетенций, управленческим навыкам [4, 8].

Утратило актуальность существовавшее долгое время представление о том, что высшее образование служит работнику своеобразной гарантией эффективной работы на долгие годы. Образование современного руководителя должно быть ориентированным на профессиональный успех, быть непрерывным и продолжаться на протяжении всей карьеры. Сегодня требуются все более современные управленческие инструменты, и руководитель, претендующий на звание успешного, должен осваивать прогрессивные подходы к построению отношений со своими подчиненными и коллегами, с внутренней организационной и внешней средой функционирования предприятия $[9,10]$.

Необходимость инвестиций (временных и финансовых) в профессиональный рост и личностное развитие руководителя с целью его постоянного совершенствования обусловлена, прежде всего, динамическими характеристиками среды и являются необходимыми условиями обеспечения конкурентоспособности как руководителя на рынке труда, так и предприятия на рынке капитала и ресурсов $[3,11]$.

Что же такое деятельность руководителя предприятия, и каковы ее особенности? Как повысить ее результативность и ценность?

Деятельность первого руководителя - это прежде всего связь со всеми многообразными аспектами деятельности предприятия, она соединяет воедино весь коллектив, создает системный характер труда и получаемых результатов. Специфика такой деятельности заключается в ее индивидуально-совместном характере - персональная ответственность руководителя сочетается с ответственностью взаимодействующих участников производственного процесса. В этой двойственности деятельности руководителя кроется одна из опасностей, хорошо знакомая профессионалу и подстерегающая новичка, - доминирование оперативной работы, переходящее в цейтнот.

\section{СТРУКТУРА РАБОТЫ РУКОВОДИТЕЛЯ}

Чрезмерная загруженность руководителя текущей, оперативной работой не позволяет ему уделять должное внимание важнейшим перспективным вопросам развития предприятия. В то же время многие из руководителей не вполне понимают, чем они могли бы наполнить свой трудовой день при освобождении их от «текучки». Поэтому остается открытым вопрос: что в большей степени опреде- ляет цейтнот - перегрузка «сиюминутным» или отсутствие у руководителя видения альтернативной деятельности?

Такая ситуация характерна не только для директора/ управляющего, но и для начальников участков, служб, цехов, мастеров. Большинство руководителей много работают, но чаще всего, несмотря на все старания, не всегда удается добиться требуемых результатов. В итоге нехватка времени становится оправданием, которое чаще всего приходится слышать руководителю, когда он обнаруживает, что очередные договоренности с подчиненным сорваны [4].

Впрочем, и сами руководители объясняют нарушение своих обязательств той же нехваткой времени: нет времени на обдумывание решений, разработку стратегии и отлаживание бизнес-процессов. При этом всегда находится время на «текучку» и «латание дыр», возникающих из-за игнорирования решения важных и срочных задач. Нет времени и на поиск причин. Зачастую они представляются подчиненным руководителю в таких формах: «человеческий фактор», «менталитет», «рассказ о борьбе с трудностями - трудностей много, времени мало», «борьба всегда героическая, а то, что нет результата - судьба» $[3,4]$.

По нашемумнению, главная причина заключается в неправильной расстановке приоритетов, нерациональной организации труда, неэффективном планировании работы и отсутствии полноценного анализа того, что делаем и как [11].

Экспертная оценка текущего состояния деятельности и результатов работы руководителя показала, что более 50\% времени руководителя тратится на ненужную (бесполезную и вредную) работу (рис. 1).

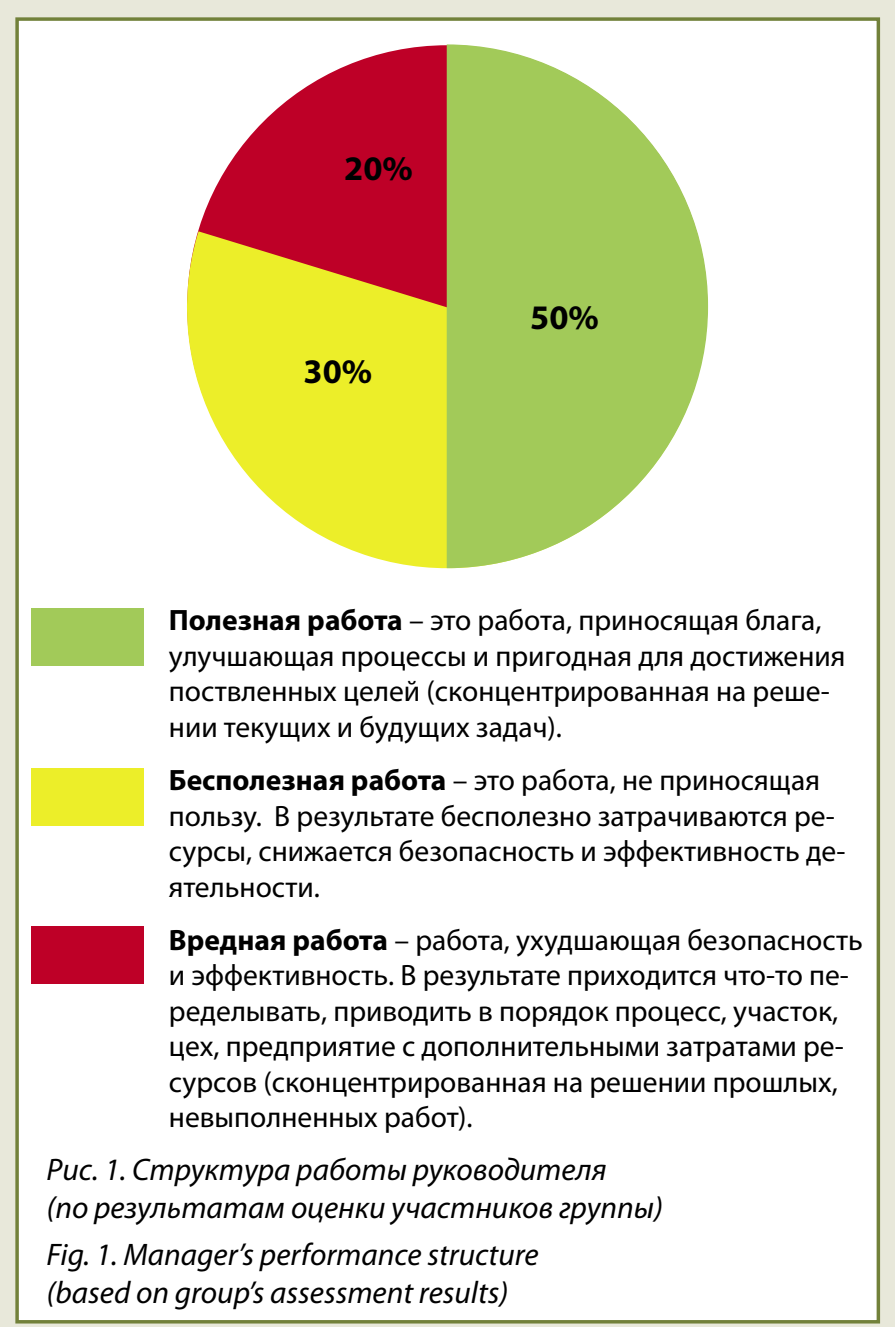


Фактическое распределение времени деятельности руководителя по типам выполняемой работы, \% (по результатам оценки участников группы на семинаре)

\begin{tabular}{|l|c|c|c|c|}
\hline \multirow{2}{*}{\multicolumn{1}{|c|}{ Тип работы }} & \multicolumn{4}{|c|}{ Работа выполнется: } \\
\hline Полезная & за подчиненного & за себя & за вышестоящего руководителя & Итого \\
\hline Бесполезная & 15 & 30 & 5 & 50 \\
\hline Вредная & 15 & 15 & 0 & 30 \\
\hline Всего 100\% & 5 & 15 & 0 & 20 \\
\hline
\end{tabular}

Кроме этого, как показывает практика, любой руководитель, в силу определенных факторов, выполняет работу как за себя, так и за подчиненного, за своего вышестоящего руководителя (табл. 1). Такое положение закладывается в модель деятельности руководителя и сохраняется как норма в культуре производства предприятия.

\section{КРИТЕРИИ ОЦЕНКИ ДЕЯТЕЛЬНОСТИ РУКОВОДИТЕЛЯ}

По факту жизни руководитель зачастую становится заложником своей системы деятельности. Нередко единственным способом управления у руководителя остается «грохнуть кулаком по столу». Это не следствие «невменяемости» подчиненных, специфики предприятия или ситуации, а традиционная «загнанность в угол» самого руководителя, то есть невозможность организовать и осуществить полноценную профессиональную деятельность.

Ценность результатов руководителя определяется не столько объемами производства, сколько эффективностью и безопасностью этого производства. Руководителю платят за то, чтобы он вырабатывал нужные для этого решения и обеспечивал с помощью управления деятельностью сотрудников их реализацию. Поэтому руководи- тель ни в коем случае не должен работать за подчиненных. По сути, это не только двойные расходы времени и денег, а «медвежья услуга», поскольку руководитель сам не развивается и не позволяет развиваться подчиненному $[9,12]$.

Для повышения ценности результатов деятельности руководителя необходима системная работа над собой и с командой единомышленников. Для оценки руководителя как лидера и результатов его деятельности могут быть использованы уже известные инструменты (табл. 2).

\section{ФАКТОРЫ, ВЛИЯЮЩИЕ НА РЕЗУЛЬТАТЫ ДЕЯТЕЛЬНОСТИ РУКОВОДИТЕЛЯ}

Основываясь на своем опыте, авторы определили основные факторы, влияющие на деятельность руководителя и ее результаты:

- наличие/отсутствие у руководителя цели. Цель - конечный результат, на который направлен процесс деятельности руководителя. Отсутствие ясной, четко понимаемой цели и путей ее достижения препятствует доведению возможностей руководителя до их полного и качественного исполнения;

- отсутствие или выбор неэффективного способа достижения цели. Способ - прием, метод, порядок действий. Выбор неэффективного способа достижения цели либо

Таблица 2

\section{Критерии оценки деятельности руководителя}

\begin{tabular}{l}
\multicolumn{1}{c}{ Критерий } \\
Рациональное \\
распределение \\
рабочего времени
\end{tabular}

Стиль руководства [5]

Тип руководства [13]

\section{Критерий определяется как:}

- отношение времени для перспективного планирования (II) ко времени для оперативной работы и решения «вчерашних» задач $(O B)$

$K_{1}=\Pi / O B$;

- отношение времени «для себя» ко времени «для других»

$K_{2}=$ ДС/ДД

Роль руководителя в подготовке и принятии решений

(семь стилей лидера по У. Шмидту и Р. Танненбауму)

- Профессиональный (универсальный).

- Корпоративный (партнерский, согласованный).

- Творческий (инновационный).

- Патриархальный (авторитарный).

- Нулевой (не участвующий в процессе управления)

Уровень руководства [13] - Идеальный - способность быть источником развития своей организации благодаря резерву.

- Эталонный - надежное функционирование в режиме достижения максимально возможных показателей. Позволяет обеспечить накопление запасов и результатов для развития своей организации. - Нормальный - функционирование в режиме средних показателей. Позволяет обеспечить устойчивое воспроизводство за счет собственных ресурсов.

- Аварийный - функционирование в режиме «латания дыр». Обеспечивается расходованием внутренних резервов и запасов.

- Нежизнеспособный - отсутствие способности к самостоятельному функционированию. Обеспечивается внешними ресурсами.

Качество функционирования предприятия [14]
Матрица поведения организации (матрица Гейгера) - позволяет определить уровень единства во взаимодействии и взаимоотношениях людей на четырех социальных уровнях: индивидуальном, групповом, межгрупповом и общесистемном 
его отсутствие приводят к нерациональному использованию рабочего времени, увеличивают сроки достижения конечного результата, либо результат не достигается;

- квалификация - способность человека делать что-либо с определенным качеством. Профессионализм - подготовленность и навыки руководителя. От уровня профессионализма руководителя зависит правильность постановки цели и способов ее достижения;

- стиль лидерства (руководства). От стиля лидерства зависит, как выстраивается структура связей между руководителем и сотрудниками;

- вовлеченность - отношение сотрудников к своей работе, которое мотивирует выполнять ее как можно лучше. Вовлеченность влияет на качество результата и затраты времени на достижение цели;

- реализуемый руководителем функционал - формирование коллектива, способного достигать поставленных целей;

- уровень доверия - уровень уверенности в добросовестности руководителя и сотрудников. От этого зависит соотношение распределения деятельности руководителя по видам работ (полезная, бесполезная, вредная работа; за себя, за подчиненного, за вышестоящего руководителя);
- расстановка приоритетов - ранжирование задач по важности для достижения цели. Качество расстановки приоритетов обеспечивает жизнеспособность предприятия;

- видение перспективы - картина того состояния предприятия, которое может быть достигнуто в отдаленном будущем с учетом опасностей и возможностей;

- способность к саморазвитию - это процесс осознанного, целенаправленного развития себя как руководителя в условиях изменяющейся окружающей среды.

Понимание и знание этих факторов руководителем позволяют ему изменить распределение своего времени в пользу полезной работы, обеспечивающей жизнеспособность предприятия (табл. 3).

При этом авторы считают необходимым сохранить выполнение части работы за вышестоящего руководителя, поскольку это дает стимул к саморазвитию и видению новых возможностей решения текущих задач более высокого уровня. Абсолютно избавиться от работы за подчиненного тоже невозможно, такие ситуации имеют место и могут быть использованы для проработки с подчиненными возможностей их профессионального роста.

Для того чтобы такая структура времени стала реальной для руководителя, необходим механизм, позволяющий ее сформировать (рис. 2).

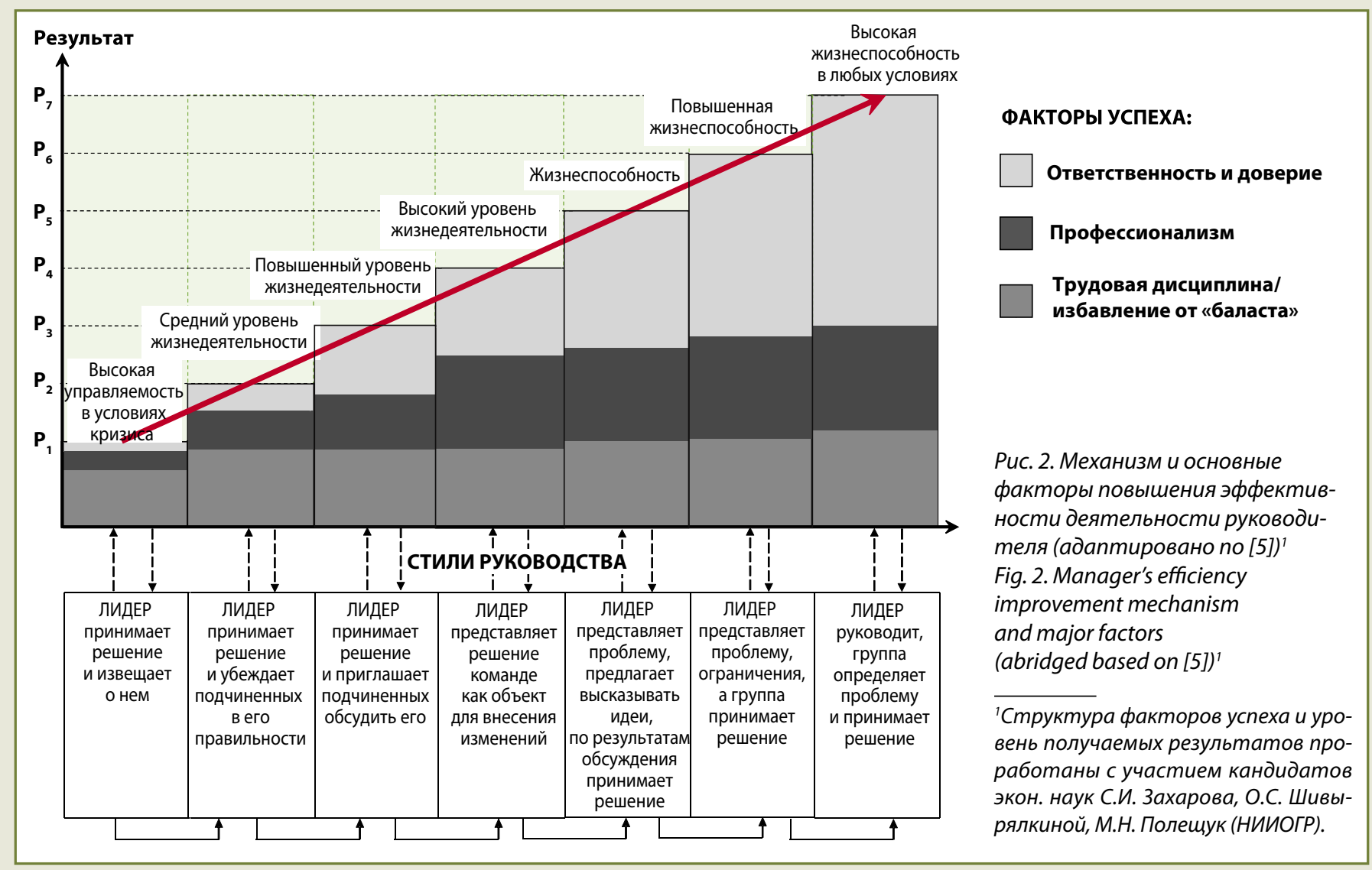

Рациональное распределение времени деятельности руководителя по типам выполняемой работы, \% (по представлениям участников группы на семинаре)

\begin{tabular}{|l|c|c|c|c|}
\hline \multicolumn{1}{|c|}{ Тип работы } & \multicolumn{3}{|c|}{ Работа выполняется: } & \multicolumn{2}{c|}{ Итого } \\
\hline Полезная & за подчиненного & за себя & за вышестоящего руководителя & 85 \\
\hline Бесполезная & 0 & 80 & 5 & 10 \\
\hline Вредная & 5 & 5 & 0 & 5 \\
\hline Всего 100\% & 0 & 5 & $\mathbf{5}$ & $\mathbf{1 0 0}$ \\
\hline
\end{tabular}


По представлениям авторов, главным компонентом механизма повышения эффективности деятельности руководителя, безусловно, является он сам, принимающий на себя роль лидера и реализующий определенный стиль руководства. Стиль руководства формируется под влиянием индивидуальных характеристик и специфических качеств руководителя, а также определяется внутриорганизационными факторами успеха, которые создаются и используются руководителем для перевода предприятия на более высокий уровень жизнеспособности [15]. К таким факторам относятся ответственность и доверие, профессионализм, трудовая дисциплина.

Поэтапный переход на более высокий уровень жизнеспособности достигается использованием взаимосвязанных и взаимообусловленных составляющих механизма: стиля руководства и факторов успеха. Базовым фактором является трудовая дисциплина, обеспечивающим - профессионализм; активизирующим - ответственность и доверие.

Использование предложенного механизма позволит изменить структуру деятельности руководителя: доля полезной работы увеличится в 1,7 раза; доля бесполезной работы уменьшится в три раза, а вредной - в четыре раза (puc. 3).

\section{ЗАКЛЮЧЕНИЕ}

«До тех пор, пока вы не научитесь управлять временем, не пытайтесь управлять ничем другим.»

Питер Друкер

Управлять эффективно - это не значит, что надо больше работать. Надо разумно действовать, рационально используя выявленные новые возможности и учитывая риски. Это, по сути, главные критерии ценности деятельности любого руководителя, нацеленного на обеспечение жизнеспособности предприятия в условиях высокого темпа изменений на рынках труда, сырья, капитала. В связи с этим необходимо целенаправленно развивать профессионализм, прежде всего первых руководителей (директоров, управляющих) предприятий, от понимания, знания, умения и навыков которых зависят безопасность и эффективность производства как в текущем, так и в долгосрочном периодах.

\section{Список литературы}

1. Беккер Г.С. Человеческое поведение: экономический подход: Избранные труды по экономической теории:Пер. с англ. М.: ГУ ВШЭ, 2003. 671 с.

2. Malik A. Efficace, hope, optimism and resilience at workplace - positive organizational behavior //International Journal of Scientific and Research Publications. 2013. Vol. 3.
№ 10 URL: http: // www.ijsrp.org/research-paper-1013/ ijsrp-p2274.pdf (дата обращения: 15.12.2017).

3. Трусь А.А. Психология управления. Минск: Вышэйшая школа, 2014. 400 с.

4. Фридман А. Вы или хаос. Профессиональное планирование для регулярного менеджмента. М.: ООО «Издательство «Добрая книга», 2015. 480 с.

5. Угледобывающее предприятие: руководитель и руководство. Отдельная статья Горного информационноаналитического бюллетеня (научно-технического журнала) / В.Б. Артемьев, А.Б. Килин, В.А. Галкин, А.М. Макаров. М.: Издательство «Горная книга», 2016. 48 с. (Сер. «Б-ка горного инженера-руководителя». Вып. 31).

6. Роль руководителя и персонала в обеспечении безопасности производства / В.Б. Артемьев, А.И. Добровольский, В.В. Лисовский и др. Отдельная статья Горного информационно-аналитического бюллетеня. М.: Горная книга, 2017. 48 с. (Сер. «Б-ка горного инженераруководителя». Вып. 32).

7. Lengnick-Hall C.A., Rigsbee C.M. Strategic Human Resource Management and Supply Chain Orientation, Human Resource Management Review, online August 18, 2012.

8. Толочек В.А. Стили деятельности: ресурсный подход. М.: Издательство «Институт психологии РАН», 2015. 366 с.

9. Килин, А.Б. и др. Цена и ценность инженерной службы угледобывающего предприятия в условиях инновационного развития / А.Б. Килин, В.А. Азев, А.С. Костарев и др. М.: Изд-во «Горная книга», 2009. 27 с. (Сер. «Б-ка горного инженера-руководителя». Вып. 2).

10. Авилов А., Розманов О., Сидоров Н. Новый взгляд на деятельность руководителя // Проблемы теории и практики управления. 1998. № 3. С. 37-48.

11. Артемьев В.Б., Галкин В.А., Макаров А.М. Резервы повышения безопасности и эффективности производства ОАО «СУЭК» в условиях кризиса // Уголь. 2015. № 2. C. 31-33. URL: http://www.ugolinfo.ru/Free/022015.pdf (дата обращения 15.12.2017).

12. Aguinis $H$. What is the Value of Human Resource Certification? A Multi-level Framework for Research, 
Human Resource Management Review, 2012. Vol. 22. pp. 246-257.

13. Хороший/плохой руководитель: из концепции эффективности деятельности, разработанной на энергоугольных предприятиях Приморского края // Уголь. 2008. Спецвыпуск СУЭК. С.19-21. URL: http://www.ugolinfo.ru/ Free/spec2008.pdf (дата обращения 15.12.2017).
14. Гейгер Э., Шеппард К. Предпосылки для эффективного управления (Ассоциация Гейгера, Германия) //Уголь. 2008. Спецвыпуск СУЭК. С. 26-28. URL: http://www.ugolinfo. ru/Free/spec2008.pdf (дата обращения 15.12.2017).

15. Махнач А.В. Жизнеспособность человека и семьи: социально-психологическая парадигма. М.: Издательство «Институт психологии РАН», 2016. 459 с.

UDC 061.3:622.8:658.3-052.2:622.33 @ A.N. Karpov, A.I. Buinitsky, A.V. Osharov, Yu.A. Kilin, O.A. Lapaeva, 2018

PRODUCTION SETUP

ISSN 0041-5790 (Print) • ISSN 2412-8333 (Online) • Ugol' - Russian Coal Journal, 2018, № 1, pp. 7-12

\section{Title}

ENTERPRISE MANAGER PERFORMANCE: ACTIVITY STRUCTURE, FACTORS, RESULTS ASSESSMENT CRITERIA

DOI: http://dx.doi.org/10.18796/0041-5790-2018-1-7-12

\section{Authors}

Karpov A.N. ${ }^{1}$, Buinitsky A.I. ${ }^{2}$, Osharov A.V. ${ }^{3}$, Kilin Yu.A. ${ }^{4}$, Lapaeva O.A. ${ }^{5}$

1 "SUEK-Krasnoyarsk", JSC branch "Borodinskoe Load and Haul Department", Borodino, 663981, Russian Federation

2 "Berezovsky Open-pit", JSC, Sharypovo, 662305, Russian Federation

3"Isykhsky Open-pit", JSC, Bely Yar, 655650, Republic of Khakassia, Russian Federation

4"Nazarovsky Open-pit", JSC, Nazarov, 662200, Russian Federation

${ }^{5}$ Chelyabinsk Mining Institute of Ural branch of RAS, Chelyabinsk, 454048, Russian Federation

\section{Authors' Information}

Karpov A.N., Manager, e-mail: KarpovAN@suek.ru

Buinitsky A.I., First General Director Deputy, e-mail: BujnitskijAI@suek.ru

Osharov A.V., Executive Director, e-mail: OsharovAV@suek.ru

Kilin Yu.A.. PhD (Engineering), First General Director Deputy,

e-mail: KilinYuA@suek.ru

Lapaeva O.A., PhD (Economic), Senior Scientific Assistant,

e-mail: lapaeva@yandex.ru

\section{Abstract}

The article presents the main results of PE leaders group activities during the conference "Industrial safety, ecology, labor protection and medicine in SUEK. Results of 2016. Tasks of 2017", held on June 26-30, 2017. They reviewed the possibilities of their activities efficiency improvement. The assessment established, that inadequate attention is given to the production system development in order to ensure enterprise viability in the conditions of the global coal market impending deterioration. It is practical to familiarize with the enterprise sustainable development function to improve enterprise viability as well as management and personnel performance value. Figures:

Fig. 1. Manager's performance structure (based on group's assessment results) Fig. 2. Manager's efficiency improvement mechanism and major factors (abridged based on [5])

Fig. 3. Manager's activity structure modification

\section{Keywords}

Manager, Performance, Structure, Factors, Assessment criteria, Result, Useful activity, Useless activity, Harmful activity, Manager's value, Viability.

\section{References}

1. Bekker G.S. CHelovecheskoe povedenie ekonomicheskiy podhod Izbrannye trudy po ekonomicheskoy teorii [Human performance: economic approach Selected studies in theoretical economics]: Translation from English. Moscow, GU VShE Publi., 2003, 671 p.

2. Malik A. Efficace, hope, optimism and resilience at workplace - posi-tive organizational behavior. International Journal of Scientific and Re-search Publications, 2013, Vol. 3, No. 10. Available at: http://www.ijsrp.org/researchpaper-1013/ijsrp-p2274.pdf (accessed 15.12.2017).

3. Trus' A.A. Psihologiya upravleniya [Management psychology]. Minsk, Vysheyshaya shkola Publ., 2014, 400 p.凶4. Fridman A. Vy ili haos Professionalnoe planirovanie dlya regulyarnogo menedzhmenta [You or chaos. Professional planning for regular management]. Moscow, Dobraya Kinga Publ., 2015, $480 \mathrm{p}$.

5. Artemiev V.B., Kilin A.B., Galkin V.A. \& Makarov A.M. Ugledobyvayushchee predpriyatie rukovoditel i rukovodstvo. Otdelnaya statya [Coal mining enter- prise: manager and management. Separate article]. Gornyy InformatsionnoAnaliticheskiy Byulleten' - Mining Information and Analytical Bulletin, Moscow, Gornaya Kniga Publ., 2016, 48 p. (Series «Mining engineer - manager's library", issue 31).

6. Artemiev V.B., Dobrovolsky A.I., Lisovsky V.V. et al. Rol rukovoditelya i personala $v$ obespechenii bezopasnosti proizvodstva. Otdelnaya statya [Manager's and personnel function in production safety assurance. Separate article]. Gornyy Informatsionno-Analiticheskiy Byulleten' - Mining Information and Analytical Bulletin, Moscow, Gornaya Kniga Publ., 2017, 48 p. (Series «Mining engineer - manager's library", issue 32).

7. Lengnick-Hall C.A. \& Rigsbee C.M. Strategic Human Resource Management and Supply Chain Orientation. Human Resource Management Review, online August 18, 2012.

8. Tolochek V.A. Stili deyatelnosti resursnyy podhod [Operating style: resource approach]. Moscow, Institut psihologii RAN Publ., 2015, 366 p.

9. Kilin A.B., Azev V.A., Kostarev A.S. et al. Tsena i tsennost inzhenernoy sluzhby ugledobyvayushchego predpriyatiya v usloviyah innovatsionnogo razvitiya [Coal mining enterprise engineering service price and value under innovative development conditions]. Moscow, Gornaya Kniga Publ., 2009, 27 p. (Series «Mining engineer - manager's library", issue 2).

10. Avilov A., Rozmanov O., Sidorov N. Novyy vzglyad na deyatelnost rukovoditelya [New vision of manager's activities]. Problemy teorii i praktiki upravleniya - Management theoretical and practical issues, 1998, No. 3, pp. 37-48. 11. Artemiev V.B., Galkin V.A., Makarov A.M. Rezervy povysheniya bezopasnosti i effektivnosti proizvodstva OAO «SUEK» v usloviyakh krizisa [Reserves for improving the production safety and efficiency of "SUEK" JSC during the recession]. Ugol' - Russian Coal Journal, 2015, No. 2, pp. 31-33. Available at: http://www.ugolinfo.ru/Free/022015.pdf (accessed 15.12.2017).

12. Aguinis H. What is the Value of Human Resource Certification? A Multilevel Framework for Research. Human Resource Management Review, 2012. Vol. 22. pp. 246-257.

13. Horoshiy plohoy rukovoditel Iz kontseptsii effektivnosti deyatelnosti razrabotannoy na enegougolnyh predpriyatiyah Primorskogo kraya [Good / bad manager: from activity performance efficiency concept, developed in Primorski krai energy coal enterprises]. Ugol' - Russian Coal Journal, 2008, Special issue SUEK, pp.19-21. Available at: http://www.ugolinfo.ru/Free/ spec2008.pdf (accessed 15.12.2017).

14. Geiger E., Sheppard K. Predposylki dlya effektivnogo upravleniya (Assotsiatsiya Geygera Germaniya) [Efficient management prerequisites (Geiger Association, Germany). Ugol' - Russian Coal Journal, 2008, Special issue SUEK, pp. 26-28. Available at: http://www.ugolinfo.ru/Free/spec2008.pdf (accessed 15.12.2017).

15. Makhnach A.V. ZHiznesposobnost cheloveka i semi sotsialno-psihologicheskaya paradigma [Human and family viability: social and phycological paradign]. Moscow, Institut psihologii RAN Publ., 2016, 459 p. 


\section{Краткий анализ проблем}

и путей их решения при обеспечении горнодобывающего предприятия

\section{современными техническими средствами ведения горных работ*}

DOI: http://dx.doi.org/10.18796/0041-5790-2018-1-13-16

Кратко охарактеризованы наиболее часто применяемые на современном этапе развития техники способы ведения горнопроходческих работ, а также обозначены некоторые перспективные технологии. В связи с научно-техническим прогрессом и постоянно повышающимися требованиями к экологичности и безопасности ведения горных работ, способствующими повышению стоимости технических средств для реализации доступа кместорождению полезных ископаемых и его последующей отработки, перед горнодобывающими компаниями возникают вызовы, связанные с рациональным использованием имеющихся финансовых ресурсов. Выявлены и тезисно описаны некоторые пути решения обозначенной проблемы. Даны нестрогие рекомендации по их применению.

Ключевые слова: горные работы, способы проходки, инвестиции, финансирование, кредитование, импортозамещение, эффект финансового рычага.

\section{ВВЕДЕНИЕ}

Разработка месторождений полезных ископаемых представляет собой комплекс взаимосвязанных организационно-технических процессов горного производства. Одним из важнейших процессов является обеспечение доступа кполезному ископаемому, реализуемое посредством горнопроходческих работ в рамках принятой стратегии развития объекта недропользования. В настоящее время существуют только два способа ведения горнопроходческих работ, применение которых экономически целесообразно: буровзрывной и механический (с применением технических средств механизации, таких как горные комбайны, проходческие щитовые комплексы и т.д.).

Буровзрывной способ является традиционным, а в некоторых горнодобывающих отраслях (например, при разработке рудных месторождений полезных ископаемых) до сих пор остается основным. В то же время повышение технического уровня средств механизации позволяет механическому способу занимать все более прочные позиции [1,

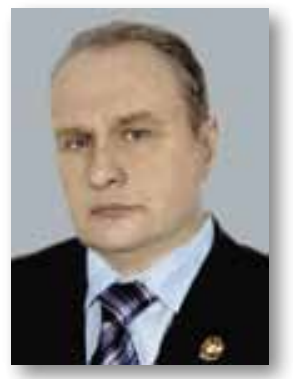

ЖАБИН Александр Борисович

Доктор техн. наук, профессор, действительный член Академии горных наук (АГН), президент Тульского регионального отделения межрегиональной общественной организации Академия горных наук (ТРО МОО АГН), Тульский государственный университет, 300012, г. Тула, Россия, тел.: +7 (4872) 25-71-05, 25-19-95, e-mail:zhabin.tula@mail.ru

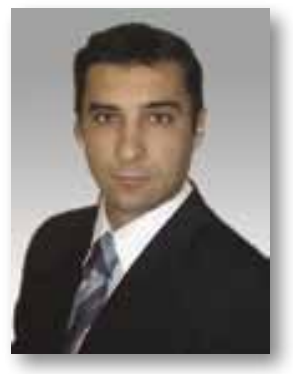

\section{поляКОВ Андрей Вячеславович}

Доктор техн. наук, профессор, академический советник АГН, TPO MOO АГН, Тульский государственный универсиmem, 300012, 2. Тула, Россия, Тел.: +7 (4872) 25-71-05, 25-19-95, e-mail:polyakoff-an@mail.ru

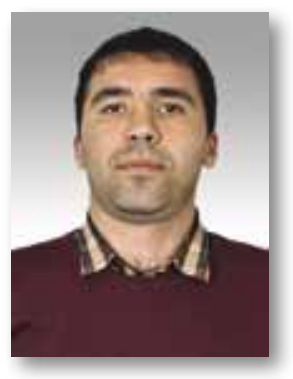

\section{АВЕРИН Евгений Анатольевич}

Канд. техн. наук, инженер-конструктор ООО «Скуратовский опытно-экспериментальный завод», 300911, г. Тула, Россия, тел.: +7 (4872) 31-35-25, 31-36-18, e-mail:evgeniy.averin.90@mail.ru 
$2,3]$. Перспективными также являются способы разрушения горных пород термическим воздействием (лазерным или электрическим нагреванием), ультразвуком, энергией микроволнового воздействия, способы химического и биологического разрушения, гидроструйные технологии. Однако широкого распространения на данный момент они не получили. Практика их применения пока ограничивается лабораторными и/или полевыми опытами или единичными промышленными экземплярами.

\section{ЭКОНОМИЧЕСКАЯ ЦЕЛЕСООБРАЗНОСТЬ ФУНКЦИОНИРОВАНИЯ ГОРНОДОБЫВАЮЩИХ ПРЕДПРИЯТИЙ}

В то же время современное развитие горных наук, как в фундаментальном, так и в прикладном аспектах, происходит на фоне тенденции все усложняющегося комбинирования технических способов и средств извлечения с целью повышения эффективности и уровня безопасности пользования недрами [4]. Этому в немалой степени способствует осуществление в России комплексного и поэтапного перехода на технологическое нормирование с учетом принципов наилучших доступных технологий в соответствии с требованиями Федерального закона Российской Федерации № 219-Ф3 «О внесении изменений в Федеральный закон «Об охране окружающей среды» и отдельные законодательные акты Российской Федерации» [5]. Подобные процессы происходят также и в зарубежных странах с развитой горной промышленностью, как по причинам естественного научно-технического прогресса [6, 7], так и под социально-политическим давлением, связанным в основном с вопросами экологии [8, 9, 10, 11, 12].

Указанные обстоятельства проявляются в новых вызовах с точки зрения экономической целесообразности функционирования горнодобывающих предприятий, поскольку повышение технического уровня средств и способов ведения горных работ зачастую означает более высокие капитальные затраты по сравнению с традиционными технологиями.

На той стадии освоения месторождения, на которой осуществляются работы по обеспечению доступа к полезному ископаемому, в качестве основного принципа стоимостной оценки проекта применяется доходный подход [13]. В условиях стабильного рынка и при наличии представительной базы сравнения также может применяться и сравнительный подход [13], однако, к сожалению, назвать российский рынок стабильным можно лишь с большой долей условности.

К доходному подходу относятся следующие методы оценки: метод дисконтированных денежных потоков и метод капитализации доходов [14]. Последний из них нежелательно использовать для оценки деятельности горнодобывающих предприятий, тем более на этапе начала их эксплуатации, поскольку он применим к стабильным компаниям с умеренными и относительно предсказуемыми темпами роста и ясной долговременной тенденцией развития.

Таким образом, эффективность применения конкретной технологии обеспечения доступа к полезному ископаемому следует оценивать с помощью метода дисконтированных денежных потоков. При этом нужно иметь в виду, что данный метод не пригоден для ранжирования альтернативных проектов [15], поскольку в общем случае они являются разнопараметрическими, то есть у них одновременно различаются такие инвестиционные параметры, как сумма инвестиций, расчетный период и ежегодные финансовые результаты [16].

В основе этого метода лежит следующая формула:

$$
N P V=\sum_{t=1}^{N} \frac{C F_{t}}{(1+i)^{t}}-I_{0} \text {, }
$$

где: $I_{0}$ - начальные инвестиции в проект, ден. ед.; $t$ - текущий временной отрезок; $N$ - суммарное количество временных отрезков (длительность проекта); $C F$ - денежный поток, ден. ед.; $i$ - ставка дисконтирования, \%/100.

Характерной особенностью проектов в горной отрасли является то, что денежные потоки на начальных и конечных временных отрезках их реализации - строго отрицательные величины. Это связано с тем, что получение положительного денежного потока (прибыли) происходит только в период добычи полезного ископаемого. Этого на начальном временном отрезке не может быть по причине отсутствия доступа к полезному ископаемому, а на конечном - по причине отработки всех кондиционных запасов и необходимости проведения специальных ликвидационных мероприятий. Отсюда естественным образом следует необходимость в минимизации количества временных отрезков (сокращении времени), необходимых для обеспечения доступа к основным залежам полезного ископаемого и сокращения затрат на ликвидацию горного предприятия на завершающем этапе проекта. Достижение данной цели для вновь создаваемых технических средств ведения горных работ должно обеспечиваться увеличением эксплуатационной производительности по сравнению с традиционными технологиями с одновременным повышением качества выполнения работ.

Затраты на приобретение технических средств ведения горных работ составляют значительную часть начальных инвестиций в проект. Целесообразно перенести эти затраты на более поздние сроки, при этом получив необходимую технику для осуществления горных работ, для чего следует воспользоваться различными способами привлечения заемного капитала.

Например, заемным капиталом могут служить сами технические средства ведения горных работ. В таком случае кредитором горнодобывающего предприятия выступает компания-поставщик горно-шахтного оборудования (ГШО). Возникает закономерный вопрос о ее заинтересованности в такой форме взаимодействия с фирмойклиентом. Если речь не идет о комплексной программе технического вооружения горнодобывающего предприятия средствами механизации, приобретаемыми у одного поставщика, когда предоставление права отсрочки платежей с использованием различных механизмов оплаты на ряд позиций номенклатуры, поставляемых в рамках заключенных контрактов, может быть оправдано масштабами сделки, то желание поставщика быть кредитором обычно стремится к нулю. Это связано с потребностью производителя ГШО в операционных финансовых ресурсах для нормального функционирования.

В связи с реализуемыми в настоящее время в России федеральными программами импортозамещения и поддержки ключевых отраслей экономики источниками фи- 
нансовых ресурсов для операционных нужд производителей ГШО могут являться различные ведомства и структуры РФ. Целесообразно для горнодобывающих предприятий, работающих на территории России, оказывать содействие отечественным производителям ГШО в процессе их взаимодействия с государственными органами по вопросам поддержки производства в значимых для развития страны отраслях. Важным критерием принятия положительного решения о выделении средств и оказании прочих видов материальной и нематериальной поддержки является явно выраженная заинтересованность потенциальных клиентов в разработках отечественных производителей. Иногда заинтересованность может выражаться только письмом от руководства конечного потребителя новой технологии в адрес соответствующего государственного ведомства с разъяснениями относительно важности приобретаемой продукции для развития подконтрольного авторам письма предприятия, если значимость такого предприятия для региона/отрасли/и так далее высока, что для горнодобывающих компаний, как правило, справедливо.

Также в качестве заемного капитала могут выступать финансовые ресурсы. Основной путь их получения - банковский кредит. Для акционерных компаний также возможен выпуск корпоративных облигаций. Несмотря на определенные риски, связанные с уменьшением финансовой устойчивости компании, привлекающей финансовые кредиты, такое решение для нее может иметь положительные последствия при соблюдении некоторых условий. Это связано с проявлением эффекта финансового рычага, показывающего процентное увеличение рентабельности собственного капитала по мере привлечения заемных средств и выражаемого формулой

$$
D F L=(1-t) \cdot(R O A-r) \cdot \frac{D}{E},
$$

где: $D F L$ - эффект финансового рычага, \%; $t$ - ставка налога на прибыль, \%/100; $R O A$ - рентабельность активов, $\% ; r$ - ставка процента по заемному капиталу, \%; $D$ - заемный капитал, ден. ед.; $E$ - собственный капитал, ден. ед.

Чем выше значение $D F L$, тем более выраженным является положительное влияние рассматриваемого эффекта. Отсюда, исходя из представленной формулы, можно сделать ложный вывод о необходимости наращивания долговой составляющей финансов предприятия. Однако по мере увеличения заемного капитала возрастает и его стоимость (процентная ставка по кредиту). И в случае превышения стоимости заемного капитала над рентабельностью собственных активов значение DFL примет большое по модулю, но отрицательное значение, что означает существенное проявление негативного влияния эффекта финансового рычага, характеризующего в таком случае финансовую неустойчивость компании.

\section{ЗАКЛЮЧЕНИЕ}

В качестве заключения отметим, что, разумеется, для обеспечения горнодобывающей компании техническими средствами ведения горных работ следует использовать одновременно различные механизмы привлечения заемного капитала. Не претендуя на «истину в последней инстанции», позволим себе дать некоторые рекоменда- ции относительно основных путей приложения усилий в поиске источников кредитования. Так, для приобретения оборудования нового технического уровня, обладающего высоким экспортным потенциалом (например, вследствие отсутствия или небольшого количества зарубежных аналогов), следует содействовать поиску точек соприкосновения производителей ГШО с государственными ведомствами для переложения на них существенной части первичного финансирования. В то же время банковские займы под такие проекты вряд ли возможно получить по приемлемой стоимости, поскольку отсутствие зарубежных аналогов банками, в отличие от государства, в большей степени будет рассматриваться не через призму потенциальных экспортных возможностей и захвата зарубежных рынков отечественными производителями, а как проект повышенного риска. Кредитование финансовыми ресурсами имеет смысл при стоимости заемных средств (ставки процента по кредиту) меньшей, чем рентабельность собственных активов.

\section{Список литературы}

1. Bilgin N., Copur H., Balci C. Mechanical excavation in mining and civil industries. CRC Press. 2013. 388 c.

2. Ozdemir L. Recent developments in hard rock mechanical mining technologies. Proc. of the 4th Canadian Symposium on Mining Automation, September 16-18, Saskatoon. 1990. Pp. 143-165.

3. Ozdemir L. Mechanical hard rock mining: Present and future // Mining engineering. 1998. Vol. 50. № 3. Pp. 36-37.

4. Доклад о состоянии фундаментальных наук в РФ и о важнейших научных достижениях российских ученых в 2016 году. М.: РАН, 2017. 380 с.

5. Федеральный закон от 21 июля 2014 г. № 219-Ф3 «О внесении изменений в Федеральный закон «Об охране окружающей среды» и отдельные законодательные акты Российской Федерации».

6. Trudel B., Nadeaua S., Zarasb K., Deschampsc l. Managing equipment innovations in mining: A review // Work. 2015. Vol. 51. № 4. Pp. 731-746. doi: 10.3233/WOR-152033.

7. Bartos P.J. Is mining a high-tech industry?: Investigations into innovation and productivity advance // Resources Policy. 2007. Vol. 32. № 4. Pp. 149-158. doi: 10.1016/ j.resourpol.2007.07.001

8. Cai L., Cui J., Jo H. Corporate environmental responsibility and firm risk // Journal of Business Ethics. 2016. Vol. 139. № 3. Pp. 563-594. doi: 10.1007/s10551-015-2630-4

9. Hajkowicz S.A., Heyenga S., Moffat K. The relationship between mining and socio-economic well being in Australia's regions // Resources Policy. 2011. Vol. 36. № 1. Pp. 30-38. doi: 10.1016/j.resourpol.2010.08.007

10. Dubiński J. Sustainable development of mining mineral resources //Journal of Sustainable Mining. 2013. Vol. 12. № 1. Pp. 1-6. doi: 10.7424/jsm130102

11. Raufflet E., Cruz L.B., Bres L. An assessment of corporate social responsibility practices in the mining and oil and gas industries // Journal of Cleaner production. 2014. Vol. 84. Pp. 256-270. doi: 10.1016/j.jclepro.2014.01.077

12. Fonseca A., McAllister M.L., Fitzpatrick P. Sustainability reporting among mining corporations: a constructive critique of the GRI approach // Journal of Cleaner Production. 2014. Vol. 84. Pp. 70-83. doi: 10.1016/j.jclepro.2012.11.050 
13. Сборник международных горных кодексов. JORC, VALMIN, Австралийское руководство по оценке и классификации угольных ресурсов. М.: Горная книга. 2015. 248 с.

14. Ревуцкий Л.Д. Качество оценок стоимости предприятий методами доходного подхода (мифы и реальность) // Аудит и финансовый анализ. 2007. № 1. С. 158-165.
15. Behrens W., Hawranek P.M. Manual for the preparation of industrial feasibility studies. Vienna: United Nations Industrial Development Organization. 1991. 404 c.

16. Коган А.Б. Новации оценки локальной и глобальной эффективности реальных инвестиций: монография. Новосибирск: НГАСУ (Сибстрин), 2012. 95 с.

ECONOMIC OF MINING

UDC 338.242:622.22:658.152 @ A.B. Zhabin, A.V. Polyakov, E.A. Averin, 2018

ISSN 0041-5790 (Print) • ISSN 2412-8333 (Online) • Ugol' - Russian Coal Journal, 2018, № 1, pp. 13-16

\section{Title}

A BRIEF ANALYSIS OF PROBLEMS AND SOLUTIONS WHEN ENSURING THE MINING ENTERPRISE WITH MODERN EQUIPMENT

DOI: http://dx.doi.org/10.18796/0041-5790-2018-1-13-16

\section{Authors'}

Zhabin A.B. ${ }^{1,2}$, Polyakov A.V. ${ }^{1,2}$, Averin E.A. ${ }^{3}$

${ }^{1}$ Tula State University, Tula, 300012, Russian Federation

${ }^{2}$ Tula Regional Department of the Academy of Mining Sciences, Tula, 300028, Russian Federation

${ }^{3}$ SOEZ, LLC, Tula, 300911, Russian Federation

\section{Authors' Information}

Zhabin A.B., Doctor of Engineering Sciences, Professor, full member of the Academy of Mining Sciences, President of the Tula Regional Department of the Academy of Mining Sciences, tel.: +7 (4872) 25-71-05, 25-19-95, e-mail:zhabin.tula@mail.ru

Polyakov A.V., Doctor of Engineering Sciences, Professor, academic advisor of the Academy of Mining Sciences, tel.: +7 (4872) 25-71-05, 25-19-95, e-mail: polyakoff-an@mail.ru

Averin E.A., PhD (Engineering), engineer-designer, tel.: +7 (4872) 31-35-25, 31-36-18, e-mail: evgeniy.averin.90@mail.ru

\section{Abstract}

The most currently used methods of mining are briefly described. There is also an outline of some promising technologies in mining. As scientific and technological progress happens, requirements for environmental friendliness and safety of mining operations are increasing. It contributes increasing the cost of technical means for access to the mineral deposit and its subsequent mining. So mining companies face the challenges associated with the rational use of available financial resources. Some ways of solving this problem have been revealed and described in the abstract. Some non-strict recommendations for their use are given.

\section{Keywords}

Mining, Mechanical excavation, Investments, Funding, Lending, Import substitution, Effect of financial leverage.

\section{References}

1. Bilgin N., Copur H. \& Balci C. Mechanical excavation in mining and civil industries. CRC Press, 2013, $388 \mathrm{p}$.

2. Ozdemir L. Recent developments in hard rock mechanical mining technologies. Proc. of the 4th Canadian Symposium on Mining Automation, September 16-18, Saskatoon, 1990, pp. 143-165.

3. Ozdemir L. Mechanical hard rock mining: Present and future. Mining engineering, 1998, Vol. 50, No. 3. pp. 36-37.

4. Doklad o sostojanii fundamental'nyh nauk $v$ RF i o vazhnejshih nauchnyh dostizhenijah rossijskih uchenyh $v 2016$ godu [Report on the state of fundamental science in Russia and the most important scientific achievements of Russian scientists in 2016]. Moscow, Russian Academy of Sciences Publ., $2017,380 \mathrm{p}$

5. Federal law of July 21, 2014 № 219-FZ “On amending the Federal law "On environmental protection" and certain legislative acts of the Russian Federation".
6. Trudel B., Nadeaua S., Zarasb K. \& Deschampsc I. Managing equipment innovations in mining: A review. Work, 2015, Vol. 51, No. 4, pp. 731-746. doi: 10.3233/WOR-152033.

7. Bartos P.J. Is mining a high-tech industry?: Investigations into innovation and productivity advance. Resources Policy, 2007, Vol. 32, No. 4, pp. 149-158. doi: 10.1016/j.resourpol.2007.07.001.

8. Cai L., Cui J. \& Jo H. Corporate environmental responsibility and firm risk. Journal of Business Ethics, 2016, Vol. 139, No. 3, pp. 563-594. doi: 10.1007/ s10551-015-2630-4.

9. Hajkowicz S.A., Heyenga S. \& Moffat K. The relationship between mining and socio-economic well being in Australia's regions. Resources Policy, 2011, Vol. 36, No. 1, pp. 30-38. doi: 10.1016/j.resourpol.2010.08.007.

10. Dubiński J. Sustainable development of mining mineral resources. Journal of Sustainable Mining, 2013, Vol. 12, No. 1, pp. 1-6. doi: 10.7424/ jsm130102.

11. Raufflet E., Cruz L.B. \& Bres L. An assessment of corporate social responsibility practices in the mining and oil and gas industries. Journal of Cleaner production, 2014, Vol. 84, pp. 256-270. doi: 10.1016/j.jclepro.2014.01.077. 12. Fonseca A., McAllister M.L. \& Fitzpatrick P. Sustainability reporting among mining corporations: a constructive critique of the GRI approach. Journal of Cleaner Production, 2014, Vol. 84, pp. 70-83. doi: 10.1016/ j.jclepro.2012.11.050.

13. Sbornik mezhdunarodnyh gornyh kodeksov. JORS, VALMIN, Avstralijskoe rukovodstvo po ocenke $i$ klassifikacii ugol'nyh resursov [Collection of international mining codes. JORC, VALMIN, Australian Guidelines for the Assessment and Classification of Coal Resources]. Moscow, Gornaya kniga Publ., 2015, 248 p.

14. Revutskiy L.D. Quality of estimations of cost of firms methods of the profitable approach (myths and a reality). Audit and financial analysis, 2007, No. 1, pp. 158-165.

15. Behrens W. \& Hawranek P.M. Manual for the preparation of industrial feasibility studies. Vienna: United Nations Industrial Development Organization, 1991, $404 \mathrm{p}$.

16. Коган А.Б. Новации оценки локальной и глобальной эффективности реальных инвестиций: монография. Новосибирск: НГАСУ (Сибстрин), 2012. 95 c.

16. Kogan A.B. Novacii ocenki lokal'noj i global'noj jeffektivnosti real'nyh investicij: monografija [Innovations assessment of the local and global efficiency of real investments: monograph]. Novosibirsk, NGASU (Sibstrin) Publ., 2012, 95 p.

\section{Acknowledgments}

Study results are published as part of the scientific project No. 2017-15PUBL. with financial support by Tula State University. 


\section{СУЭК первой в России и странах СНГ получила сертификат соответствия стандарту ISO 55001 «Менеджмент активов»}

11 декабря 2017 г. руководитель разработки Cтандартов ISO 9001, ISO 55001, ISO 31000, секретарь технических и проектных комитетов Британского Института Стандартов и ISO Чарльз Корри официально вручил заместителю генерального директора - директору по производственным операциям АО «СУЭК» Владимиру Артемьеву сертификат соответствия международному стандарту ISO 55001 «Менеджмент активов». СУЭК стала первой компанией в России и странах СНГ, которая успешно прошла данный аудит и получила сертификат соответствия по данному стандарту.

Аудит проводился компанией BSI (British Standard Institute). В процессе ayдита представители BSI посетили все производственные единицы СУЭК, где оценили уровень организации работ задействованных служб, провели личные встречи с техническими директорами, главными инженерами, главными механиками, инженерами ППР. Аудиторы оценивали уровень учета основных средств, узлов оборудования, наработок и простоев, ремонтов, электроэнергии, системы нормирования МТР и системы управления рисками. Особой проверке была подвергнута используемая информационная система КИС ПАРУС.

«Это значимое событие не только для СУЭК, но и для мировых компаний, которые только планируют начать использование этого стандарта, - прокомментировал чарльз Корри. - Считаю, что управление активами - это самый главный, основополагающий кирпичик вверху всей системы. Получение сертификата - это не финальный прочесс, но это начало пути. С одной стороны, вы проделали большую работу, но еще больше работы теперь предстоит в вашей ежедневной деятельности. Я желаю вам успешно использовать систему в дальнейшем».
«Когда 10 лет назад мы начали работу по систематизации управления активами компании, то думали прежде всего о том, как, начиная с технической политики и продолжая эксплуатацией машин и механизмов, правильно всем этим распоряжаться, управлять нашими активами, не тратить лишние средства. В дальнейшем появилась идея оценить пройденный путь, что и было в результате подтверждено сертификатом. СУЭК ставит амбициозные задачи соответствия самым лучшим, самым передовым мировым стандартам. Мы рады, что наша работа получила достойную оценку», - сказал Владимир Артемьев в ходе встречи.

\section{Наша справка.}

АО «СУЭК»-одна из ведущихугледобывающих компаний мира, крупнейший в России производитель угля, крупнейший поставщик на внутренний рынок и на экспорт. Добывающие, перерабатывающие, транспортные и сервисные предприятия СУЭК расположены в восьми регионах России. На предприятиях СУЭК работают более 33500 человек. Основной акционер - Андрей Мельниченко.

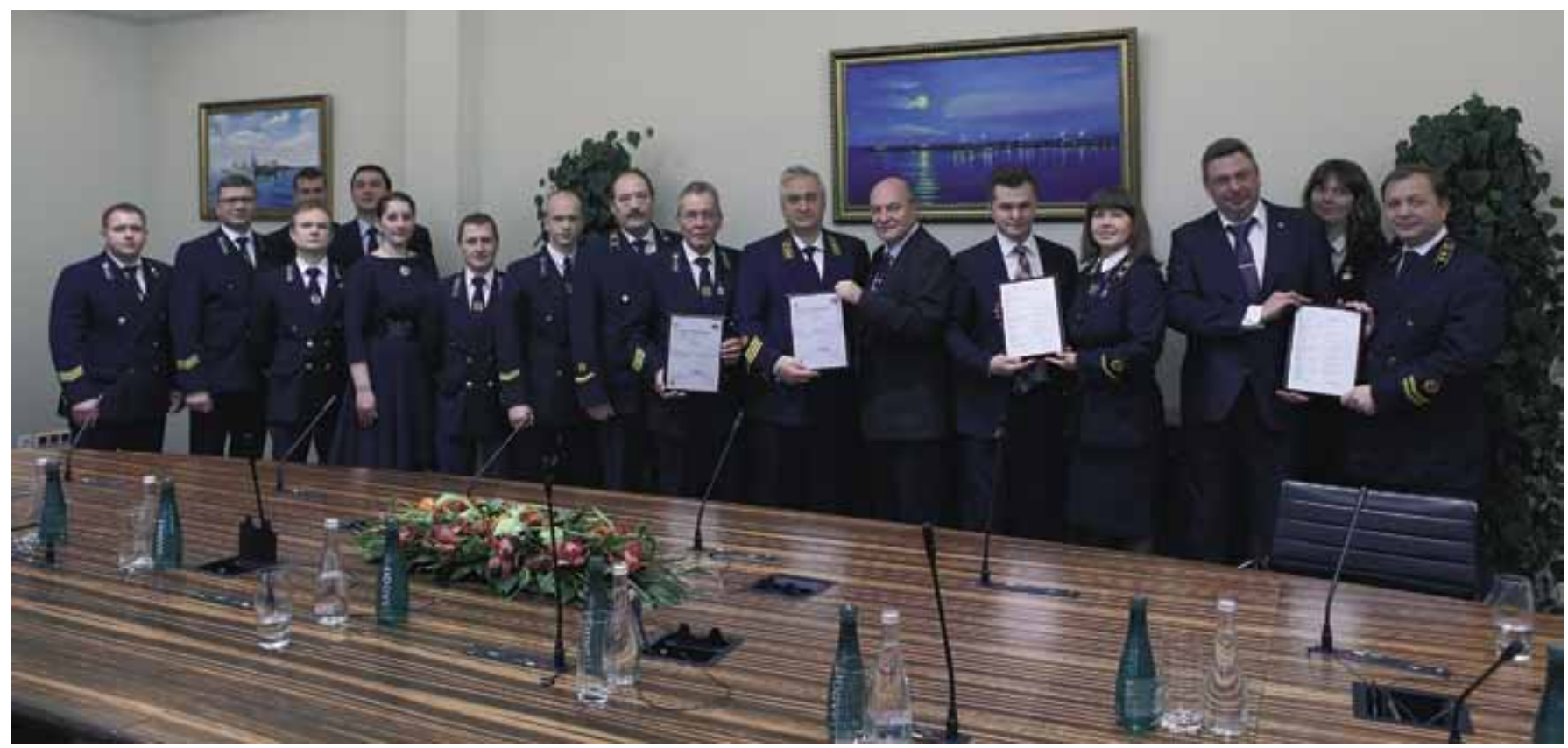




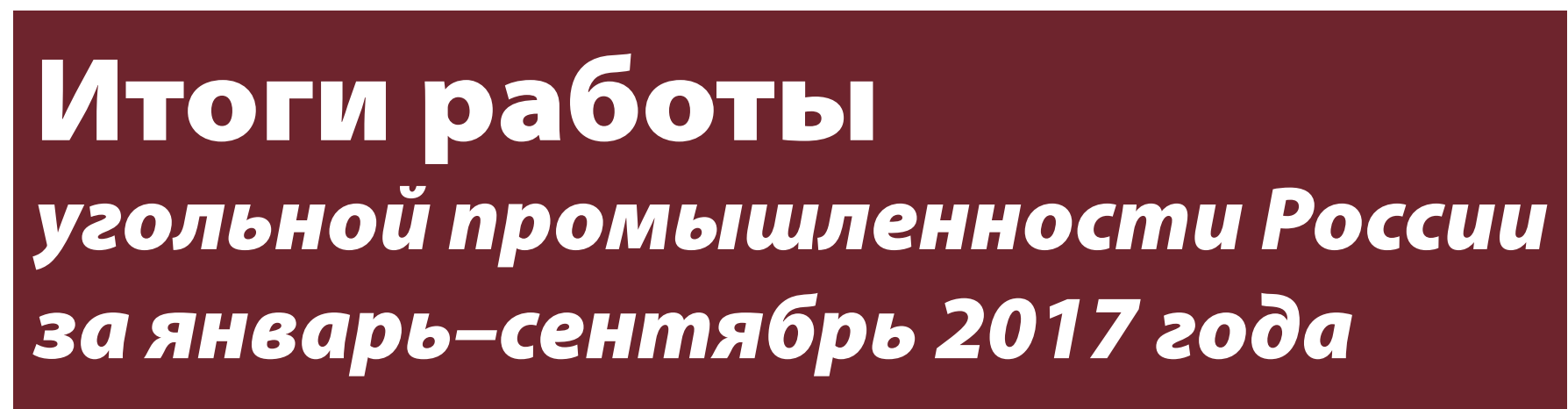

Составитель:

ТАРАЗАНОВ Игорь Геннадьевич

Использованы данные: ФГБУ «ЦДУ ТЭК», Росстата, АО «Росинформуголь», Департамента угольной и торфяной промышленности Минэнерго России, пресс-релизы компаний.
Добыча угля в России, млн $m$

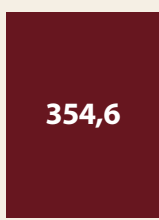

2012

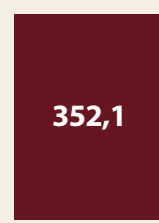

2013

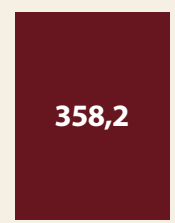

2014

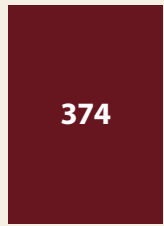

2015

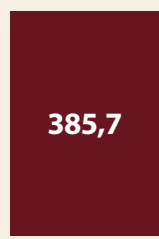

2016

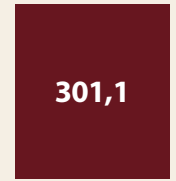

9 мес. 2017
DOI: http://dx.doi.org/10.18796/0041-5790-2018-1-18-32

Россия является одним из мировых лидеров по производству угля, она занимает шестое место по объемам угледобычи после Китая, США, Индии, Австралии и Индонезии (на долю России приходится примерно 4,5\% мировой угледобычи).

Фонд действующих угледобывающих предприятий России по состоянию на 01.10.2017 насчитывает 178 предприятий (шахты - 61, разрезы - 117). Переработка угля в отрасли осуществляется на 65 обогатительных фабриках и установках, а также на имеющихся в составе большинства угольных компаний сортировках.

В результате проведенной в ходе реструктуризации угольной промышленности приватизации угольных активов практически вся добыча угля осуществляется акционерными обществами с частной формой собственности.

В пределах Российской Федерации находятся 22 угольных бассейна и 129 отдельных месторождений. Добыча угля ведется в семи федеральных округах, 25 субъектах

Российской Федерации. В отрасли задействовано около 148 тыс. человек, а с членами их семей - около 700 тыс. человек.

Уголь потребляется во всех субъектах Российской Федерации. Основные потребители угля на внутреннем рынке это электростанции и коксохимические заводы. Из угледобывающих регионов самым мощным поставщиком угля является Кузнецкий бассейн - здесь производится более половины (60\%) всего добываемого угля в стране и 73\% углей коксующихся марок.

Наиболее перспективными по запасам и качеству угля, состоянию инфраструктуры и горнотехническим возможностям являются, помимо предприятий Кузбасса, также разрезы Канско-Ачинского бассейна, Восточной Сибири и Дальнего Востока, дальнейшее развитие которых позволит обеспечить основной прирост добычи угля в отрасли. С точки зрения наращивания производственного потенциала наиболее перспективными становятся районы Восточной Сибири и Дальнего Востока.

\section{ДОБЫЧА УГЛЯ}

Добыча угля в России за январь-сентябрь 20172. составила 301,1 млн т. Она возросла по сравнению с 9 мес. 2016 г. на 17,2 млн т, или на 6\%. Поквартальная добыча составила: в первом - 99,9; во втором - 99,5; в третьем - 101,7 млн т.

Подземным способом добыто 80,8 млн т угля (на 2,2 млн т, или на 3\% больше, чем годом ранее). Из них поквартальная добыча составила: в первом - 25,5; во втором - 28,2; в третьем - 27,1 млн т.

За январь-сентябрь 2017 г. проведено 302,1 км горных выработок (на 30,6 км, или на 11\% выше прошлогоднего уровня), в том числе вскрывающих и подготавливающих выработок - 263,2 км (на 33,7 км, или на 15\% больше, чем годом ранее). При этом уровень комбайновой проходки составляет 88\% общего объема проведенных выработок.

Добыча угля открытым способом составила 220,3 млн $\boldsymbol{m}$ (на 15 млн т, или на 7\% выше уровня 9 мес. 2016 г.). Из них поквартальная добыча составила: в первом - 74,4; во втором - 71,3; в третьем - 74,6 млн т. Объем вскрышных работ за январь-сентябрь 2017 г. составил 1430,6 млн куб. м (на 186,4 млн куб. м, или на 15\% выше объема аналогичного периода 2016 г.).

Удельный вес открытого способа в общей добыче составил 73,2\% (годом ранее было 72,3\%). 
Добыча угля в России (по способам добычи), млн $m$
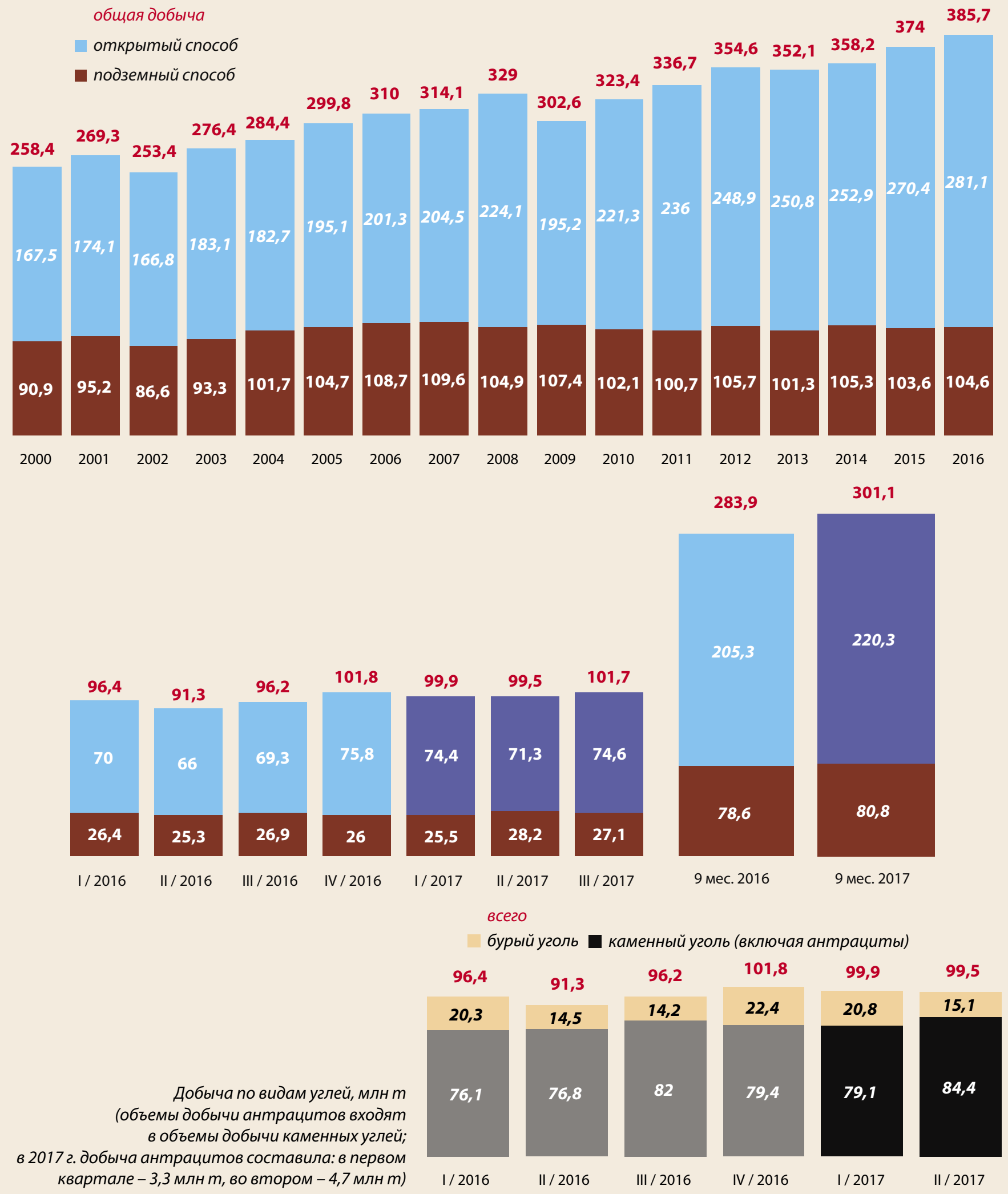

\section{ДОБЫЧА УГЛЯ ПО ТЕРРИТОРИЯМ}

В январе-сентябре 2017 г. по сравнению с аналогичным периодом прошлого года добыча угля увеличилась в трех из четырех основных угольных бассейнов страны: в Кузнецком - на 11,8 млн т, или на 7\% (добыто 180,5 млн т), в Канско-Ачинском - на 0,6 млн т, или на 2\% (добыто 26,15 млн т) и в Донецком - на 1 млн т, или на 29\% (добы- то 4,55 млн т). Снижение отмечено в Печорском угольном бассейне - на 1,19 млн т, или на 14\% (добыто 7,03 млн т).

В январе-сентябре 2017 г. по сравнению с 9 мес. 2016 г. добыча угля возросла в пяти из семи угледобывающих экономических районов России: в Западно-Сибирском добыто 188,3 млн т (рост на 9\%), в Восточно-Сибирском - 68,5 млн т 
(рост на 2\%), в Дальневосточном - 31,6 млн т (рост на $2 \%)$ в Южном - 5,55 млн т (рост на 29\%) и в Уральском 0,83 млн т (рост на 10\%). Снижение отмечено в двух экономических районах: в Северном добыто 7,1 млн т (спад на 15\%) и в Центральном - 199 тыс. т (спад на 8\%).
В целом по России объем угледобычи за год увеличился на 17,1 млн т, или на $6 \%$.

Основной вклад в добычу угля по Российской Федерации вносят Западно-Сибирский (62\%) и Восточно-Сибирский (23\%) экономические районы.

Добыча угля по основным бассейнам, млн $m$

9 мес. 2013

9 мес. 2014

9 мес. 2015

9 мес. 2016

9 мес. 2017

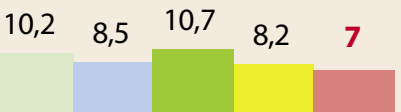

Печорский бассейн

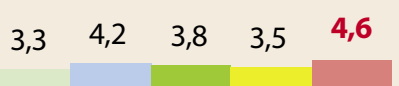

Донбасс

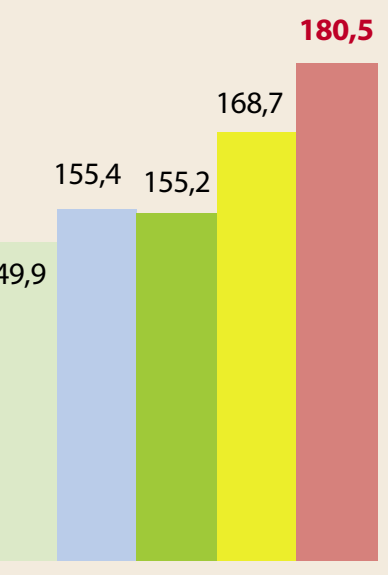

Кузбасс

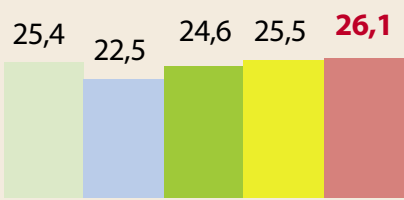

Канско-Ачинский бассейн

\section{Десятка наиболее крупных \\ системообразующих предприятий (компаний) по добыче угля в России, тыс. т* \\ 1. $\mathbf{A O}$ «СУЭК»}

- АО «СУЭК-Кузбасс» (Кемеровская обл.)

- Филиал АО «СУЭК-Красноярск»

«Разрез Бородинский имени М.И. Щадова»

(Красноярский край)

- $А O$ «Разрез Березовский»

(Красноярский край)

- $A O$ «Разрез Назаровский»

(Красноярский край)

- $А О$ «Разрез Тугнуйский»

(Республика Бурятия)

- ООО «СУЭК-Хакасия» (Республика Хакасия)

- ООО «Восточно-Бейский разрез»

(Республика Хакасия)

- ОАО «Разрез Изыхский» (Республика Хакасия)

- АО «Ургалуголь» (Хабаровский край)

- АО «Разрез Харанорский»

(Забайкальский край)

- ООО «Читауголь» (Забайкальский край)

- ООО «Арктические разработки»

(Забайкальский край)

- ООО «Приморскуголь» (Приморский край)

- АО «Шахтоуправление Восточное»

(Приморский край)

\section{2. ОАО «УК «Кузбассразрезуголь»}

- Филиал «Талдинский угольный разрез»

- Филиал «Бачатский угольный разрез»

- Филиал «Краснобродский угольный разрез»

- Филиал «Моховский угольный разрез»

- Филиал «Кедровский угольный разрез»

- Филиал «Калтанский угольный разрез»

- ООО «Шахта Байкаимская»

\section{3. АО ХК «СДС-Уголь»}

- ЗАО «Разрез Первомайский»

- $А О$ «Черниговещ»

- ООО «Шахта Листвяжная»

- $А О$ «Салек» (разрез «Восточный»)

- Филиал АО «Черниговец» - Шахта «Южная»

\begin{tabular}{|c|c|}
\hline $\begin{array}{c}9 \text { мес. } \\
2017\end{array}$ & $\begin{array}{c}+/- \\
\text { к уровню } \\
\mathbf{9} \text { мес. 2016 }\end{array}$ \\
\hline $\mathbf{7 7 8 8 2}$ & $-\mathbf{9 9 8}$ \\
\hline 29049 & -463 \\
\hline 13570 & 341 \\
\hline 2953 & -381 \\
\hline
\end{tabular}

Десятка наиболее крупных
системообразующих предприятий
(компаний) по добыче угля в России, тыс. т*

- ООО «Сибэнергоуголь»

(разрез «Бунгурский-Южный»)

\begin{tabular}{|l|l|l|}
\hline - ООО «Разрез «Киселевский» & 1456 & -162 \\
\hline
\end{tabular}

- ЗАО «Прокопьевский угольный разрез»

- ООО «Объединение «Прокопьевскуголь»

(шахты «Зиминка», «Красногорская»)

$2387 \quad 86$

$10416 \quad-324$

$6103 \quad-292$

$2632 \quad 126$

\begin{tabular}{l|l}
831 & 67
\end{tabular}

$4637 \quad 26$

$1854-346$

\begin{tabular}{l|l}
826 & 237
\end{tabular}

\begin{tabular}{l|l}
461 & 384
\end{tabular}

$2111 \quad 300$

$52-371$

$34985 \quad 1359$

$10006 \quad 343$

$7454 \quad 358$

$5519 \quad-314$

$4892 \quad 974$

$3809-28$

$3155 \quad 173$

$150 \quad-147$

$21734 \quad 764$

$4418 \quad 360$

$4297-100$

$3892 \quad 1082$

$3154 \quad-64$

$1854 \quad-184$

4. 000 «Распадская угольная компания» (EBPA3)

- ПАО «Распадская»

- ОАО «ОУК «Южкузбассуголь»

\begin{tabular}{|c|c|}
\hline $\begin{array}{c}\mathbf{9} \text { мес. } \\
\mathbf{2 0 1 7}\end{array}$ & $\begin{array}{c}+/- \\
\text { к уровню } \\
\mathbf{9} \text { мес. 2016 }\end{array}$ \\
\hline 1478 & -17 \\
\hline 1456 & -162 \\
\hline 1185 & -89 \\
\hline- & -62 \\
\hline
\end{tabular}

5. ОАО «Мечел-Майнинг»

- АОХК «Якутуголь»

- ПАО «Южный Кузбасс»

- ООО «Эльгауголь»

\begin{tabular}{|c|c|}
\hline 17058 & 1005 \\
\hline 8559 & 1245 \\
\hline 8499 & -240 \\
\hline $\mathbf{1 5 6 9 4}$ & $\mathbf{- 1 3 9 3}$ \\
\hline
\end{tabular}

6. АО «Русский Уголь»

$6408-1135$

$6237 \quad-424$

$3049 \quad 166$

- ОАО «Красноярсккрайуголь»

- $A O$ «УК «Разрез Степной»

3872

3108

- $А О$ «Амуруголь»

2389

- ООО «Саяно-Партизанский»

7. En+ Group

620

- ООО «Компания «Востсибуголь»

10174

- Разрез «Ирбейский» (Компания

7955

«Востсибуголь»)

- ООО «Тувинская ГРК»

8. ПАО «Кузбасская Топливная Компания»

9. 000 «УК «ЕВРАЗ Междуреченск»

- $A O$ «Междуречье»

- $А О$ «Угольная компания «Южная»

- $А O$ «Шахта «Большевик»

- АО «Шахта «Антоновская»

10. 3 АО «Стройсервис»

- ООО «Разрез «Березовский»

1811

408

9430

8721

4689

2594

942

496

7500

3636

- ООО «Разрез «Пермяковский»

1951

- ООО СП «Барзасское товарищество»

947

615

- $А О$ «Разрез «Шестаки»

- OOO «Шахта № 12»

351

527

519

$-41$

12

37

445

414

$-11$

* Указанные компании суммарно обеспечивают 75\% всего объема добычи угля в России. 
Добыча угля (удельный вес) по основным угледобывающим экономическим районам за январь-сентябрь 2017 г.

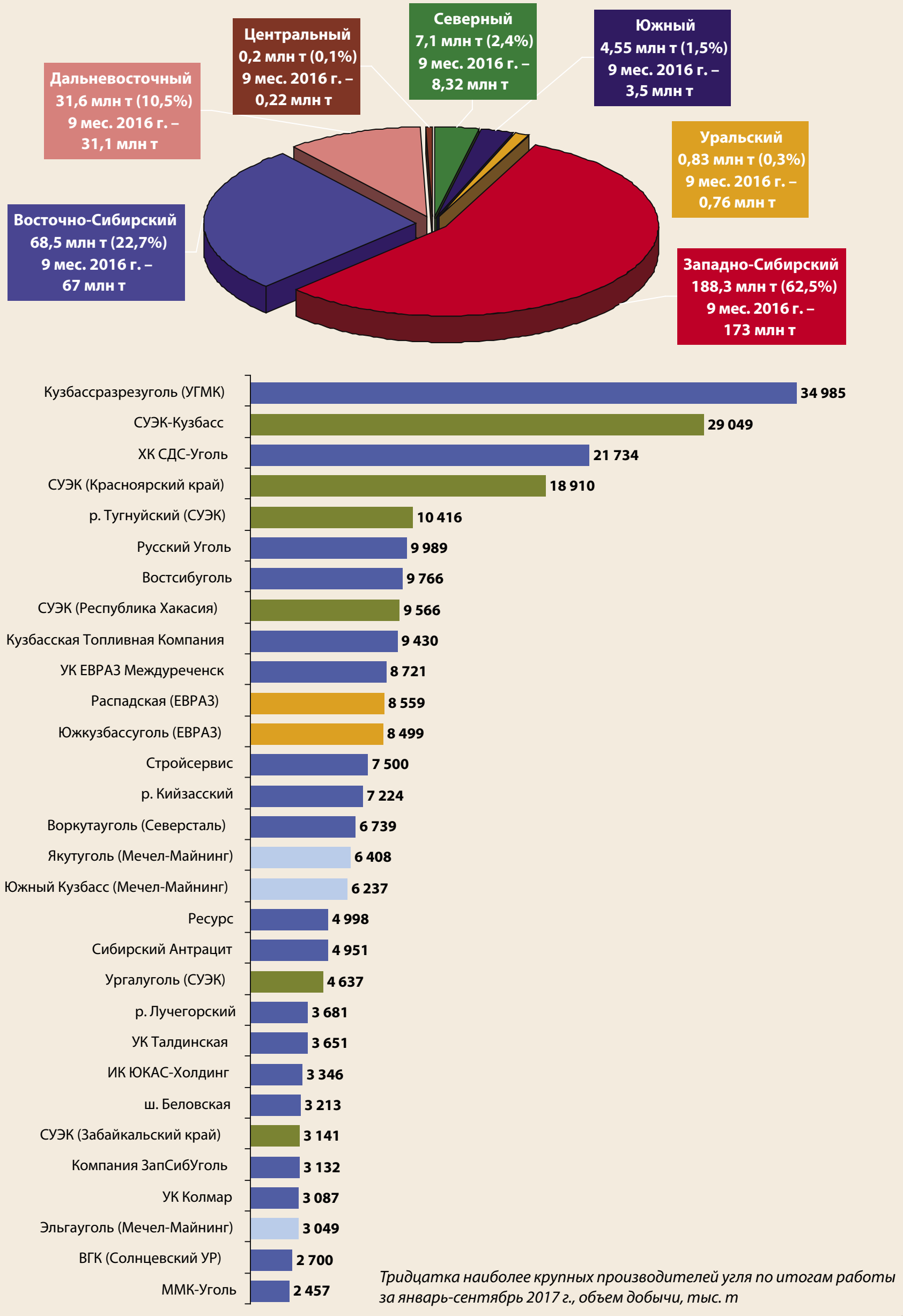




\section{ДОБЫЧА УГЛЯ ДЛЯ КОКСОВАНИЯ}

В январе-сентябре 2017 г. было добыто 65,7 млн т коксующегося угля, что на 2,2 млн т, или на 3\% ниже уровня 9 мес. 2016 г. Из них поквартальная добыча составила: в первом квартале - 20,5; во втором - 21,7; в третьем - 23,5 млн т коксующихся углей.

Доля углей для коксования в общей добыче составила только 22\%. Основной объем добычи этих углей пришелся на предприятия Кузбасса - 73\%. Здесь было добы- то 48,3 млн т угля для коксования, что на 1,66 млн т меньше, чем годом ранее (спад на $3 \%$ ). Добыча коксующегося угля в Печорском бассейне составила 6,74 млн т (9 мес. 2016 г. - 7,37 млн т, спад на 9\%). В Республике Саха (Якутия) было добыто 10,28 млн т угля для коксования (годом ранее было 10,53 млн т, спад на 2\%). В Забайкальском крае было добыто 363 тыс. т угля для коксования (9 мес. 2016 г. 22 тыс. т, рост в 16 раз).

Добыча угля в России по видам углей, млн $m$

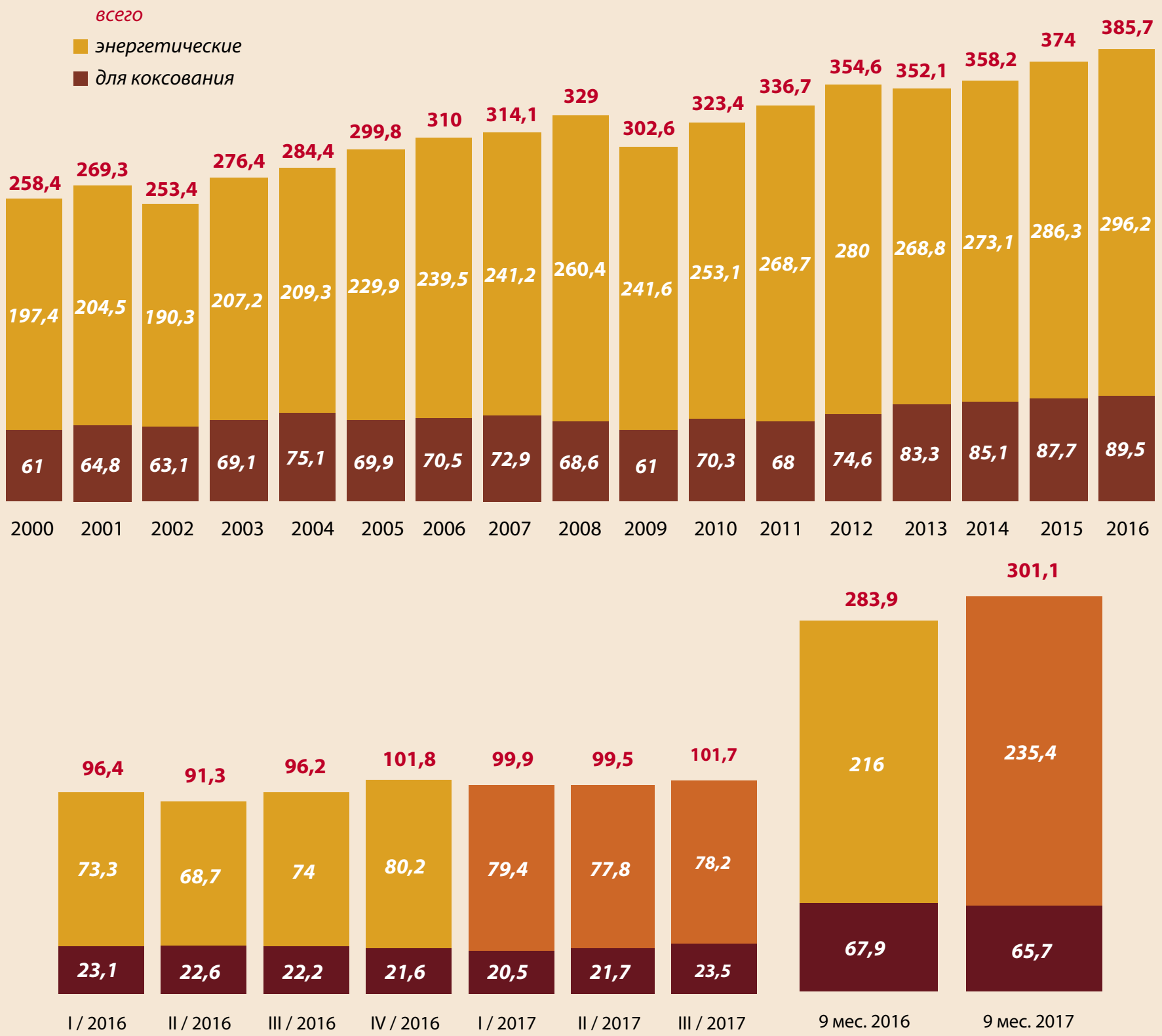

По результатам работы в январе-сентябре 20172. наиболее крупными производителями угля для коксования являются: ЕВРАЗ (17058 тыс. m, в том числе ПАО «Распадская» - 8559 тыс. $m$, ОАО «ОУК «Южкузбассуголь» - 8499 тыс. m);ОАО «Мечел-Майнинг» (10629 тыс. m, в том числе АОХК «Якутуголь» - 5465 тыс. m, ПАО «Южный Кузбасс» - 2691 тыс. m, ООО «Эльгауголь» - 2473 тыс. m); АО «Воркутауголь» (6739 mыс. m); ОАО «УК «Кузбассразрезуголь» (4623 тыс. $\mathrm{m}$ ); ООО «УК «ЕВРАЗ Междуреченск»

(4606 тыс. m, в том числе $A O$ «Междуречье» - 3168 тыс. m, AO «Шахта «Большевик» - 942 тыс. $m$, , АО «Шахта «Антоновская» - 496 тыс. m); 3АО «Стройсервис» (3310 mыс. m, в том числе ООО «Разрез «Березовский» - 2207 тыс. $m$, ООО СП «Барзасское товарищество» - 551 тыс. $m$, OОО «Шахта № 12»- 282 mыс. $m$, АО «Разрез «Шестаки» - 270 mыс. m); АО ХК «СДС-Уголь» (2537 mыс. m); ООО «ММК-УГОЛЬ» (2457 тыс. m); ОАО «Шахта «Полосухинская» (2262 тыс. $\mathrm{m})$. 
Российские производители коксующегося угля (добыча за январь-сентябрь 2017 г., тыс. m)

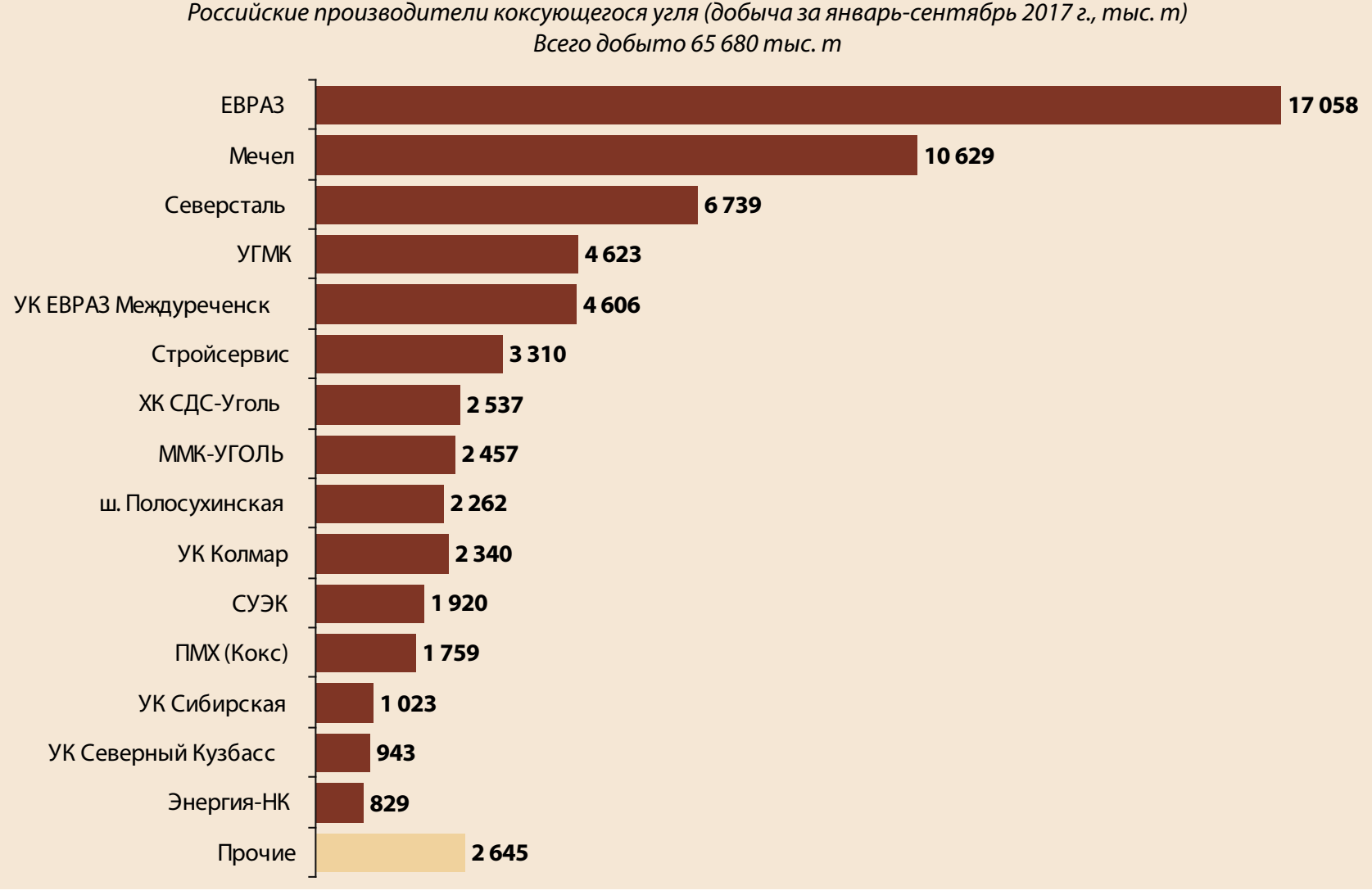

\section{НАГРУЗКА НА ЗАБОЙ И ПРОИЗВОДИТЕЛЬНОСТЬ}

В январе-сентябре 2017 г. среднесуточная добыча угля из одного действующего очистного забоя в среднем по отрасли составила 4730 m. За год этот показатель увеличился на 1,5\% (9 мес. 2016 г. - 4658 т).

3а этот же период среднесуточная нагрузка на комплексномеханизированный очистной забой в среднем по отрасли составила 5052 m, что на 3\% выше уровня января-сентября 2016 г., а на лучших предприятиях она значительно превышает среднеотраслевой показатель.

По итогам 9 мес. 2017 г. наиболее высокая среднесуточная добыча из действующего очистного забоя достигнута на следующих предприятиях: $\mathrm{AO}$ «СУЭК-Кузбасс» - 13076 т; АО Шахтоуправление «ТалдинскоеКыргайское» - 8787 т; ООО «Шахта Листвяжная» - 7733 т; Филиал АО «Черниговец» - Шахта «Южная» - 7606 т; ООО «Шахта Байкаимская» - 6803 т; ПАО «Распадская» - 6385 т;

По основным бассейнам среднесуточная добыча угля из одного действующего очистного забоя в январесентябре 2017 г. составила: в Кузнецком - 5560 т (из комплексно- механизированного забоя - 6022 т); в Печорском - 3069т (из КМЗ - 3069т); в Донецком - 2715 т (из КМЗ 2715 т); в Республике Хакасия - 1888 т (из КМЗ - 1888 т);
Динамика среднесуточной добычи угля из действующего очистного забоя, $m$

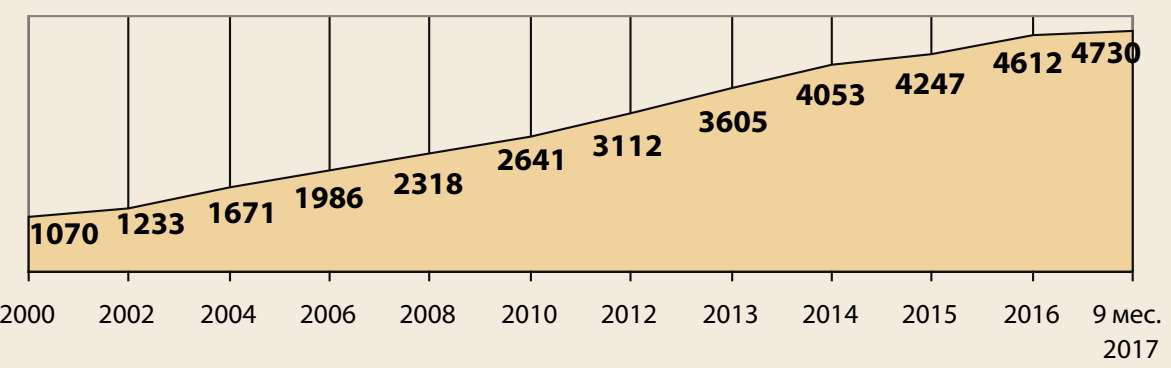

Динамика среднесуточной нагрузки

на комплексно-механизированный забой (КМЗ), $m$

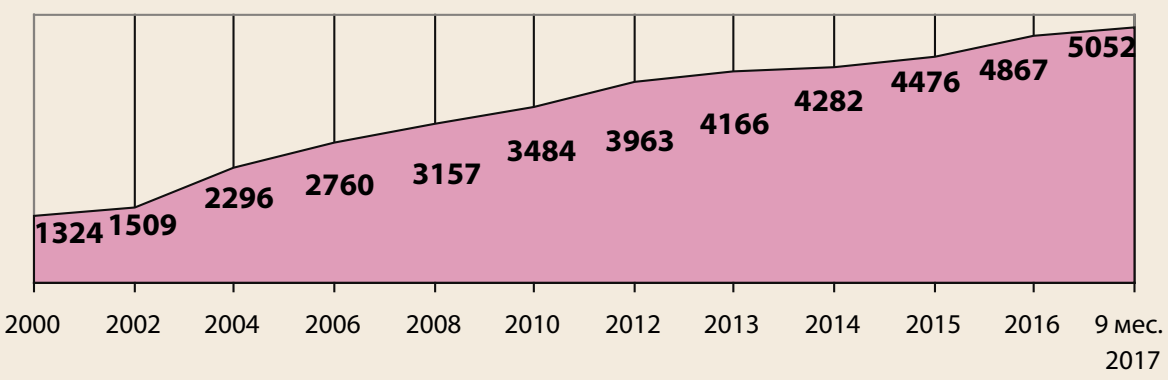

в Дальневосточном регионе - 3298 т (из КМЗ - 4117 т).

Удельный вес объемов добычи угля из комплексномеханизированных очистных забоев в общей подземной добыче в январе-сентябре 2017 г. составил 84,9\% (на 0,6\% меньше, чем годом ранее). По основным бассейнам этот показатель составил (\%): в Печорском - 86,6 (9 мес. 2016 г. - 87,6); в Донецком - 90,5 (9 мес. 2016 г. - 87,7); в Кузнецком - 85,6 (9 мес. 2016 г. - 86,7); в Дальневосточном регионе - 62,7 (9 мес. 2016 г. - 56,2). 
Среднедействующее количество комплексно-механизированных очистных забоев в январе-сентябре 2017 г. составило 55,3. Годом ранее было 63,4, т.е. уменьшилось на $13 \%$. По основным бассейнам этот показатель составил: в Печорском - 7,1 (9 мес. 2016 г. - 9,6); в Донецком 5,7 (9 мес. 2016 г. - 5,4); в Кузнецком - 37,1 (9 мес. 2016 г. - 35,7); в Республике Хакасия - 0,8 (9 мес. 2016 г. - 0,8); в Дальневосточном регионе - 3,6 (9 мес. 2016 г. - 10,9).

По итогам работы в январе-сентябре 2017 г. среднемесячная производительность труда рабочего по добыче угля (квартальная) составила 322,4 m. Годом ранее производительность труда была 307 т/мес., т.е. она увеличилась на 5\%. При этом производительность труда рабочего на шахтах составила 221,8 т/мес., на разрезах - 401 т/мес. За период с начала двухтысячных годов производительность труда рабочего возросла в 2,9 раза (в 2000 г. она составляла в среднем 110,3 т/мес.).
Среднедействующее количество КМЗ

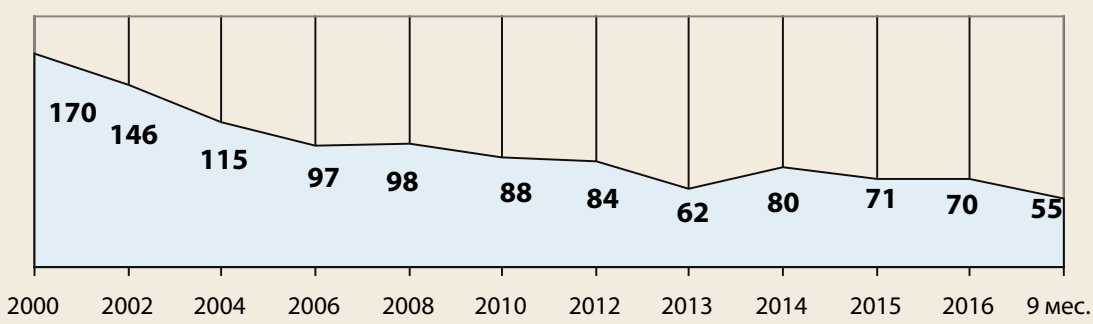

2017

Производительность труда рабочего по добыче, $\mathrm{m} /$ мес.

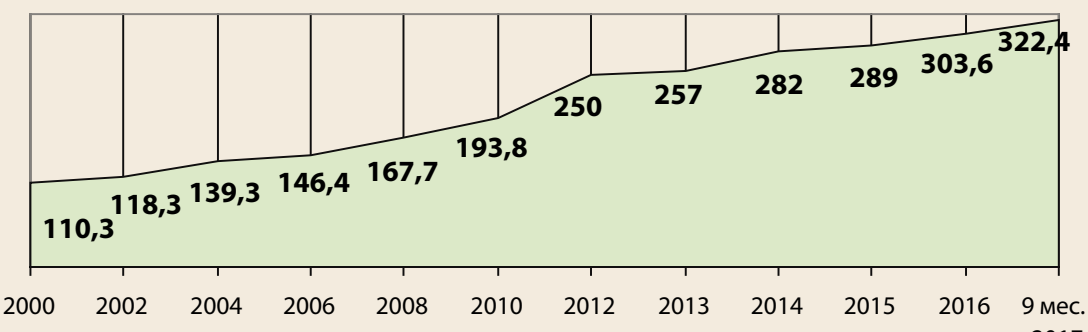

2017

\section{СЕБЕСТОИМОСТЬ}

\section{Себестоимость добычи 1 т угля} за январь-август 2017 г. составила 1755,52 руб. За год она увеличилась на 248,78 руб.Приэтомпроизводственнаясебестоимость добычи 1 тугля увеличилась на 120,88 руб. и составила 1293,42 руб., а внепроизводственные расходы на добычу 1 т увеличились на 127,90 руб. и составили 462,10 руб. В свою очередь производственная себестоимость по элементам затрат распределена следующим образом: материальные затраты составили 718,21 руб./т (рост на 75,85 руб./т по сравнению с январем-августом 2016 г.); расходы на оплату труда - 193,46 руб./т (рост на 13,87 руб./т); отчисления на социальные нужды - 74,15 руб./т (рост на 3,18 руб./т); амортизация основных фондов - 155,25 руб./т (рост на 3,24 руб./т); прочие расходы - 152,36 руб./т (рост на 24,75 руб./т).

\section{Структура себестоимости добычи 1 т угля} в январе-августе 2016-2017 г2., \%

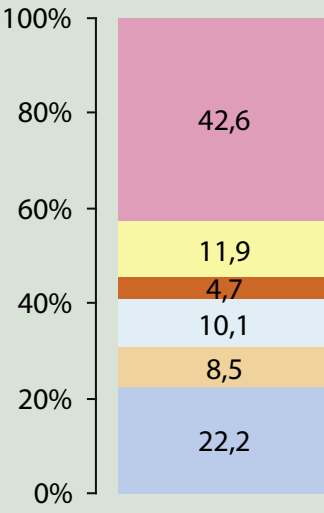

8 мес. 2016

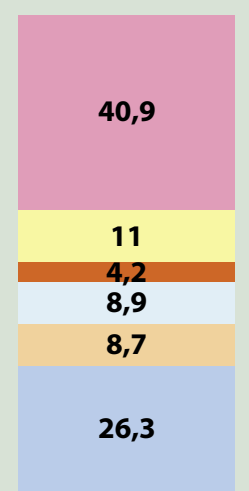

8 мес. 2017
Материальные затраты

Расходы на оплату труда

Отчисления на социальные нужды

Амортизация основных фондов

Прочие расходы

Внепроизводственные расходы

\section{ЧИСЛЕННОСТЬ ПЕРСОНАЛА}

Численность работников по угледобывающим компаниям, шахтам и разрезам по состоянию на 01.07.2017 составила 148 тыс. человек, из них по основному виду деятельности - 141 тыс. человек, рабочих по добыче - 95,8 тыс. человек. Для сравнения - на 1 января 2017 г. численность персонала составляла 145,1 тыс. человек.

Средняя численность работников предприятий угледобычи и переработки на конец сентября 2017 г. составила 139,7 тыс. чел. и за год снизилась на 318 человек. При этом среднесписочная численность работников по основному виду деятельности на угледобывающих и углеперерабаты- вающих предприятиях на конец сентября 2017 г. составила 134,3 тыс. чел., т.е. за год уменьшилась на 357 человек. Среднесписочная численность рабочих по добыче угля (квартальная), по предварительным данным, составила 86,79 тыс. чел. (годом ранее было 87,17 тыс. чел.), из них на шахтах - 38,06 тыс. чел. (9 мес. 2016 г. - 38,48 тыс. чел.) и на разрезах - 48,73 тыс. чел. (9 мес. 2016 г. - 48,69 тыс. чел.).

Среднемесячная заработная плата одного работника на российских предприятиях угледобычи и переработки на конец сентября 2017 г. составила 50348 руб., за год она увеличилась на $9 \%$. 
Динамика численности работников угольной отрасли, тыс. человек

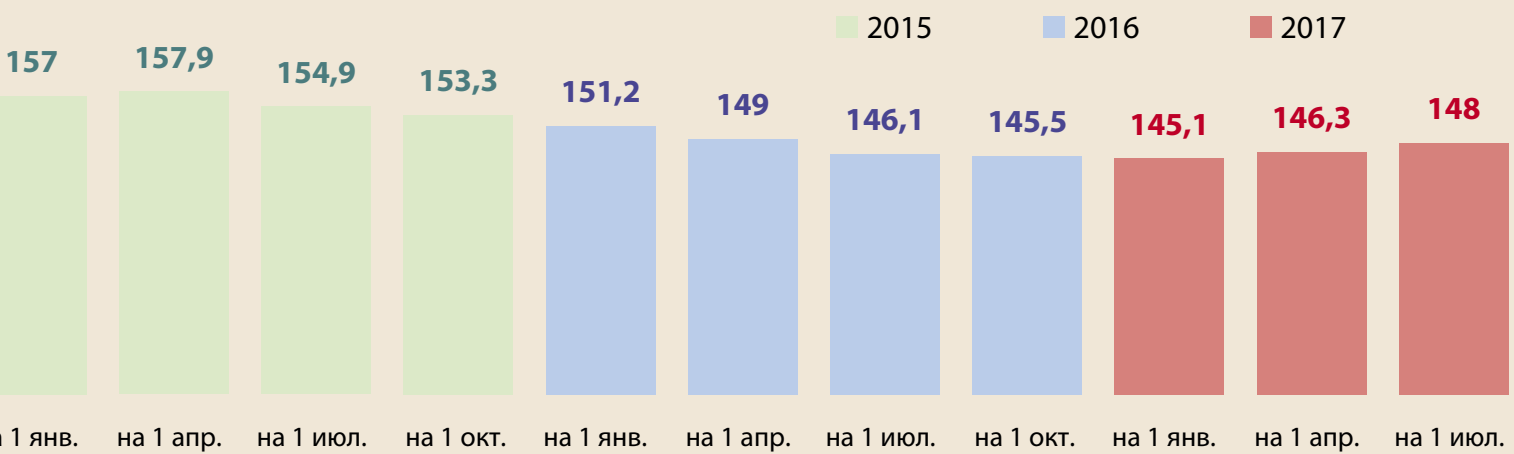

Средняя численность персонала угледобывающих и перерабатывающих предприятий и среднемесячная заработная плата одного работника

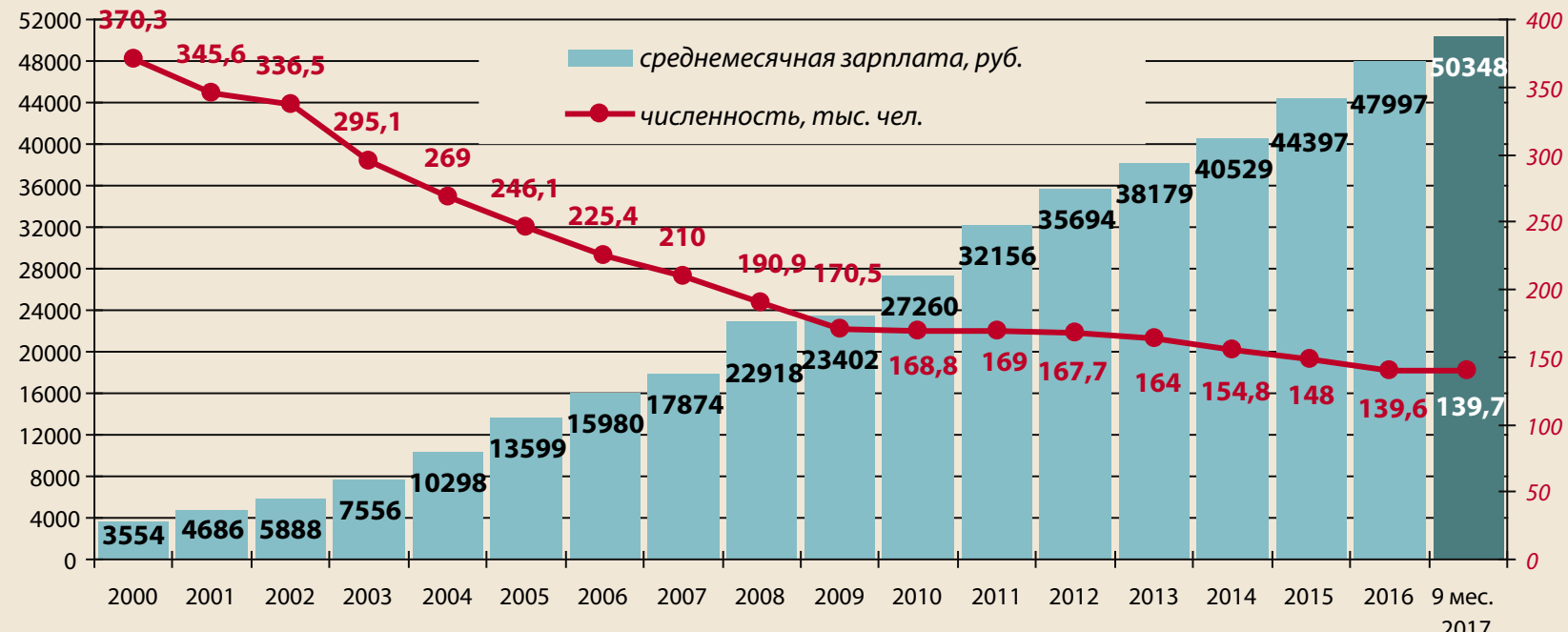

\section{ПЕРЕРАБОТКА УГЛЯ}

Обций объем переработки угля в январе-сентябре 2017 г. с учетом переработки на установках механизированной породовыборки составил 145,4 млн $\mathrm{m}$ (на 5,8 млн т, или на 4\% выше уровня 9 мес. 2016 г.).

На обогатительных фабриках переработано 141,3 млн $\boldsymbol{m}$ (на 4,8 млн т, или на 4\% больше, чем годом ранее), в том числе для коксования - 66,1 млн т (на 1,6 млн т, или на 2\% ниже уровня 9 мес. 2016 г.).

Выпуск концентрата составил 79,7 млн т (на 3,5 млн т, или на 5\% больше, чем годом ранее), в том числе для кок- сования - 41,7 млн т (на 0,9 млн т, или на 2\% ниже уровня января-сентября 2016 г.).

Выпуск углей крупных и средних классов составил 12,4 млн т (на 0,98 млн т, или на 9\% больше, чем годом ранее), в том числе антрацитов - 1,16 млн т (на 300 тыс. т, или на 35\% выше уровня 9 мес. 2016 г.).

Дополнительно переработано на установках механизированной породовыборки 4,09 млн т угля (на 990 тыс. т, или на 32\% выше уровня 9 мес. 2016 г.).

Переработка угля на обогатительных фабриках в январе-сентябре 2017 г., тыс. т

\begin{tabular}{|c|c|c|c|c|c|c|}
\hline \multirow[b]{2}{*}{ Бассейны, регионы } & \multicolumn{3}{|c|}{ Bcero } & \multicolumn{3}{|c|}{ В том числе для коксования } \\
\hline & $\begin{array}{l}9 \text { мec. } \\
2017\end{array}$ & $\begin{array}{l}9 \text { мec. } \\
2016\end{array}$ & $\begin{array}{l}\text { к уровню } \\
9 / 2016, \%\end{array}$ & $\begin{array}{l}9 \text { мec. } \\
2017\end{array}$ & $\begin{array}{l}9 \text { мec. } \\
2016\end{array}$ & $\begin{array}{l}\text { к уровню } \\
9 / 2016, \%\end{array}$ \\
\hline Всего по России & 141302 & 136499 & 103,5 & 66079 & 67681 & 97,6 \\
\hline Печорский бассейн & 5798 & 7983 & 72,6 & 5502 & 7130 & 77,2 \\
\hline Донецкий бассейн & 3119 & 2682 & 116,3 & - & - & - \\
\hline Челябинская обл. & 830 & 985 & 84,3 & - & - & - \\
\hline Новосибирская обл. & 4100 & 2915 & 140,6 & - & - & - \\
\hline Кузнецкий бассейн & 94826 & 90084 & 105,3 & 52529 & 52326 & 100,4 \\
\hline Республика Хакасия & 8690 & 7622 & 114,0 & - & - & - \\
\hline Иркутская обл. & 2166 & 2208 & 98,1 & - & - & - \\
\hline Забайкальский край & 8992 & 8903 & 101,0 & - & - & - \\
\hline Республика Саха (Якутия) & 8048 & 8225 & 97,9 & 8048 & 8225 & 97,9 \\
\hline Хабаровский край & 4602 & 4338 & 106,1 & - & - & - \\
\hline Приморский край & 65 & 413 & 15,9 & - & - & - \\
\hline Сахалинская обл. & 66 & 142 & 46,5 & - & - & - \\
\hline
\end{tabular}


Выпуск концентрата в январе-сентябре 2017 г., тыс. т

\begin{tabular}{|c|c|c|c|c|c|c|}
\hline \multirow[b]{2}{*}{ Бассейны, регионы } & \multicolumn{3}{|c|}{ Bcero } & \multicolumn{3}{|c|}{ В том числе для коксования } \\
\hline & $\begin{array}{l}9 \text { мec. } \\
2017\end{array}$ & $\begin{array}{l}9 \text { мес. } \\
2016\end{array}$ & $\begin{array}{l}\text { к уровню } \\
9 / 2016, \%\end{array}$ & $\begin{array}{l}9 \text { мес. } \\
2017\end{array}$ & $\begin{array}{l}9 \text { мec. } \\
2016\end{array}$ & $\begin{array}{l}\text { к уровню } \\
9 / 2016, \%\end{array}$ \\
\hline Всего по России & 79704 & 76198 & 104,6 & 41719 & 42615 & 97,9 \\
\hline Печорский бассейн & 2513 & 3492 & 71,9 & 2436 & 3330 & 73,2 \\
\hline Донецкий бассейн & 1723 & 1415 & 121,7 & - & - & - \\
\hline Челябинская обл. & 2 & 3 & 66,7 & - & - & - \\
\hline Новосибирская обл. & 833 & 611 & 136,5 & - & - & - \\
\hline Кузнецкий бассейн & 57166 & 53533 & 106,8 & 34518 & 34227 & 100,8 \\
\hline Республика Хакасия & 5740 & 5074 & 113,1 & - & - & - \\
\hline Иркутская обл. & 1465 & 1424 & 102,9 & - & - & - \\
\hline Забайкальский край & 4121 & 4151 & 99,3 & - & - & - \\
\hline Республика Саха (Якутия) & 4765 & 5057 & 94,2 & 4765 & 5057 & 94,2 \\
\hline Хабаровский край & 1321 & 1218 & 108,5 & - & - & - \\
\hline Приморский край & 17 & 118 & 14,4 & - & - & - \\
\hline Сахалинская обл. & 38 & 102 & 37,4 & - & - & - \\
\hline
\end{tabular}

Выпуск углей крупных и средних классов в январе-сентябре 2017 г., тыс. т

\begin{tabular}{|l|c|c|c|}
\multicolumn{1}{|c|}{ Бассейны, регионы } & $\mathbf{9}$ мес. 2017 & $\mathbf{9}$ мес. 2016 & K уровню 9/2016, \% \\
\hline Всего по России & $\mathbf{1 2 4 3 9}$ & $\mathbf{1 1 4 6 2}$ & $\mathbf{1 0 8 , 5}$ \\
\hline Печорский бассейн & 77 & 162 & 47,2 \\
\hline Донецкий бассейн & 904 & 700 & 129,1 \\
\hline Челябинская обл. & 2 & 3 & 66,7 \\
\hline Новосибирская обл. & 833 & 611 & 136,5 \\
\hline Кузнецкий бассейн & 3833 & 4108 & 93,3 \\
\hline Республика Хакасия & 4555 & 3924 & 116,1 \\
\hline Иркутская обл. & 691 & 633 & 109,2 \\
\hline Республика Саха & 186 & 79 & 236,3 \\
\hline Амурская обл. & 37 & 25 & 147,0 \\
\hline Хабаровский край & 1321 & 1217 & 108,5
\end{tabular}

Динамика обогащения угля на обогатительных фабриках России, млн $m$

всего

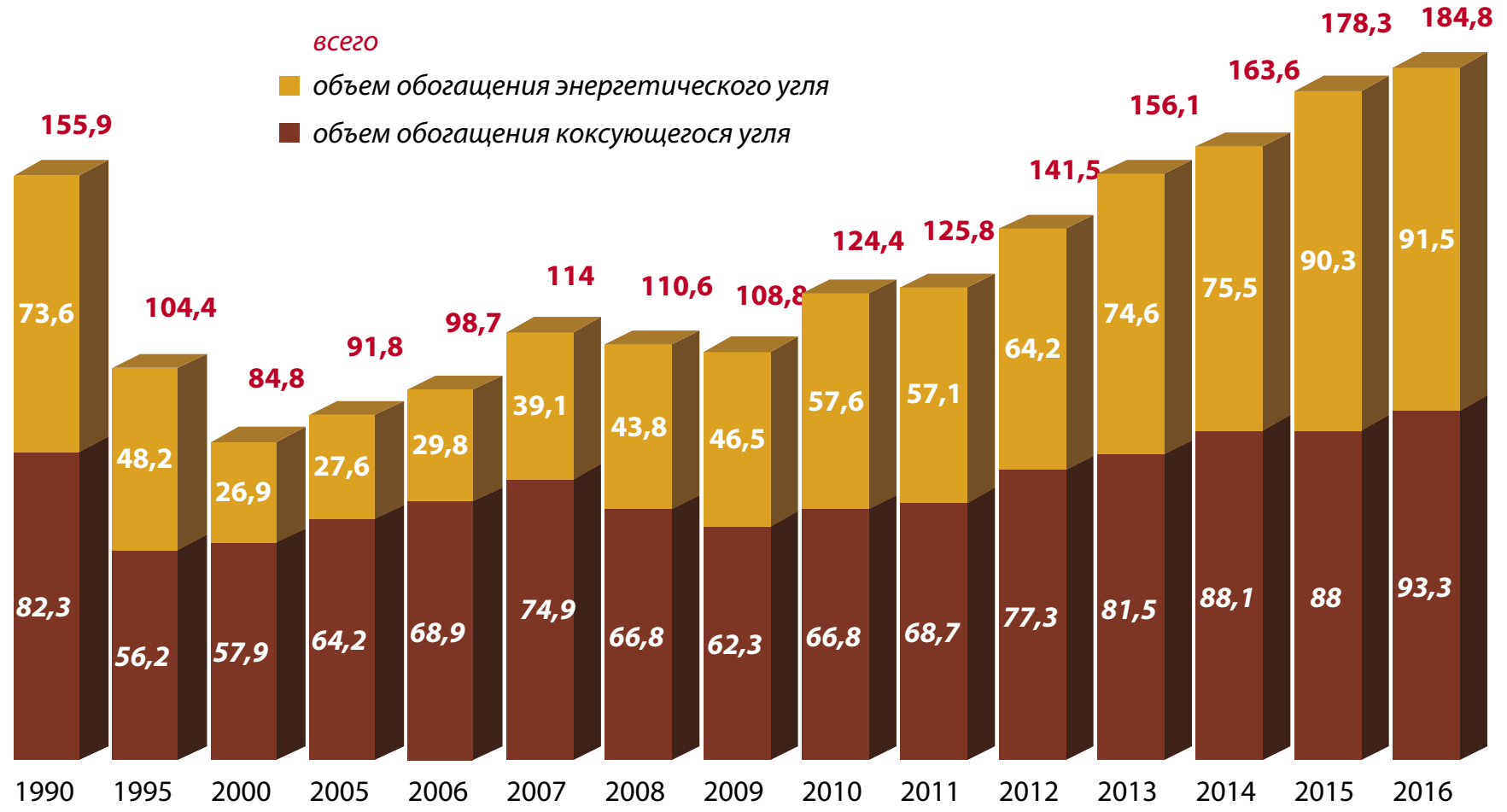


Коксующийся уголь практически весь обогащается, энергетический - только $30 \%$.

141,3

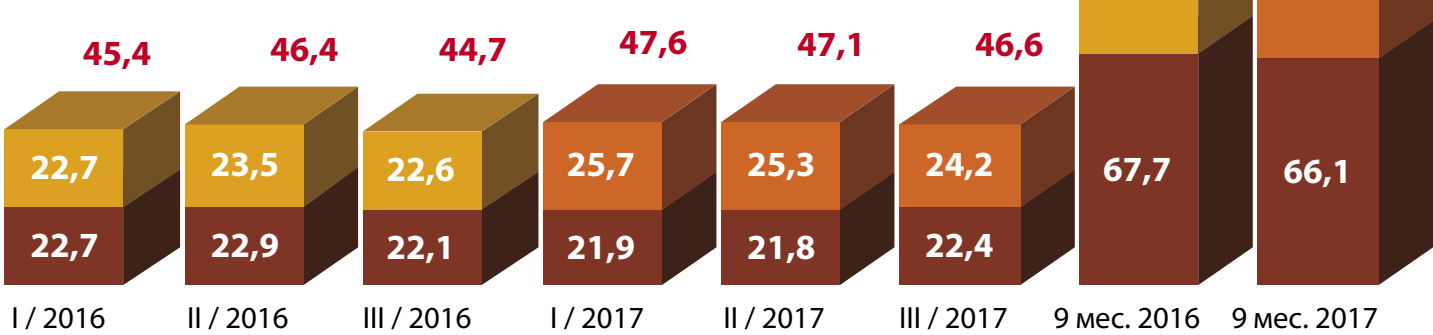

\section{ПОСТАВКА УГЛЯ}

Угледобывающие предприятия России в январесентябре 20172. поставили потребителям 261,5 млн т угля, что на 21,9 млн т, или на 9\% больше, чем годом ранее.

Из всего поставленного объема на экспорт отправлено 140,3 млн т. Это на 19,4 млн т, или на 16\% выше уровня соответствующего периода 2016 г.

Поставка российских углей основным потребителям, млн $m$

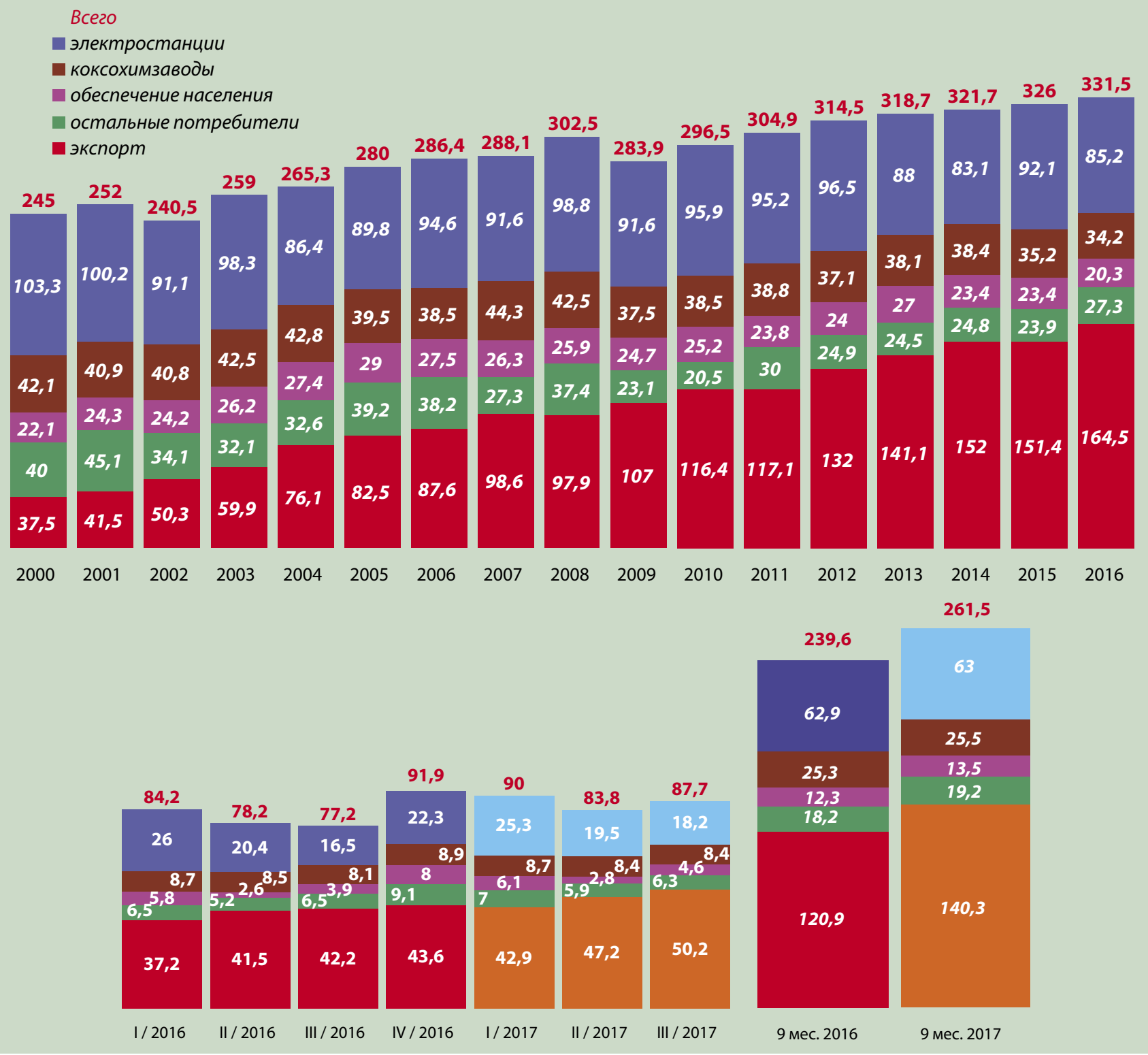


Внутрироссийские поставки составили 121,2 млн т, что на 2,5 млн т, или на 2\% больше, чем годом ранее.

По основным направлениям внутрироссийские поставки распределились следующим образом:

- обеспечение электростанций - 63 млн т (увеличились на 0,1 млн т, или на 1\%);

- нужды коксования - 25,5 млн т (увеличились на 0,2 млн т, или на 1\%);
- обеспечение населения, коммунально-бытовые нужды, агропромышленный комплекс - 13,5 млн т (увеличились на 1,2 млн т, или на 10\%);

- остальные потребители (нужды металлургии, энергетика, РАО «РЖД», Минобороны, Минюст, МВД, Минтранс, ФПС, Атомная промышленность, Росрезерв, цементные заводы и др.) - 19,2 млн т (увеличились на 1,0 млн т, или на $5 \%$ ).

Поставка российских углей, млн $m$

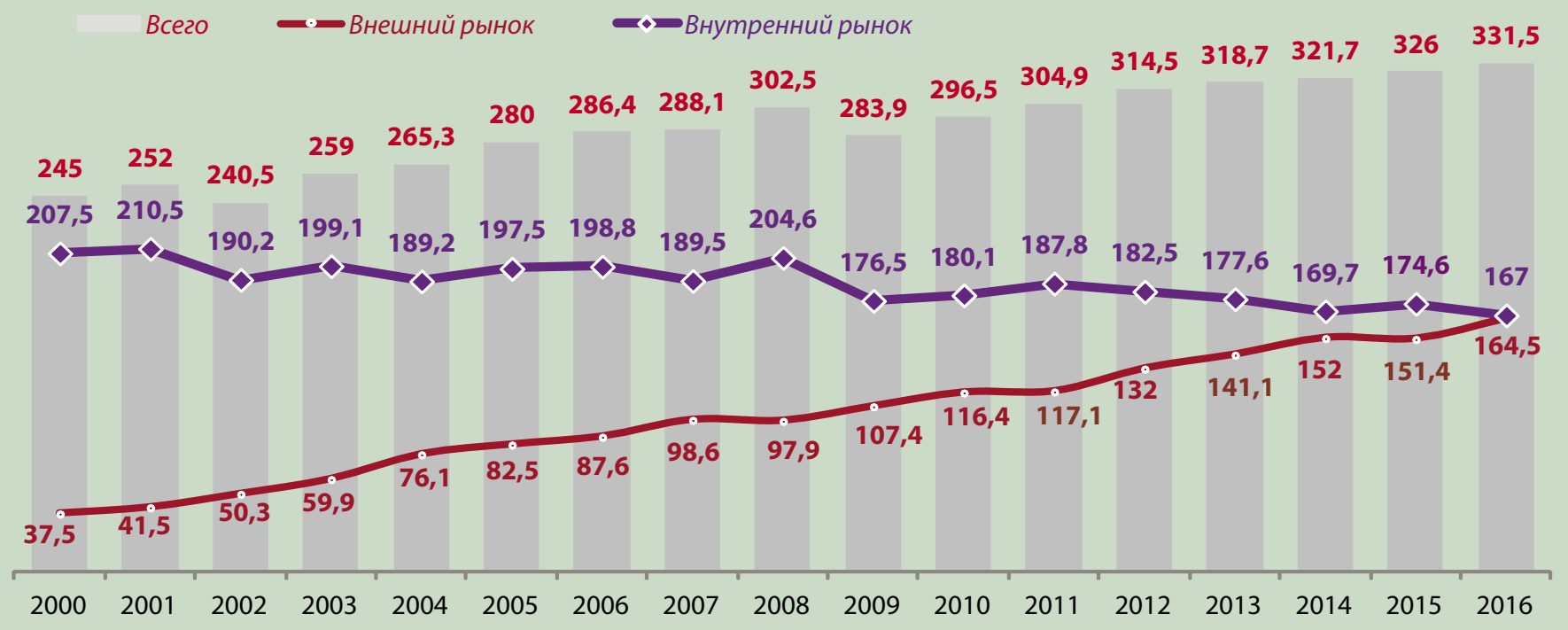

\section{ЗАВОЗ И ИМПОРТ УГЛЯ}

Завоз и импорт угля в Россию в январе-сентябре 20172. по сравнению с соответствуюцим периодом 2016г. увеличилисьна 1,8 млн т, или на 12\% и составили 16,8 млн т.

Завозится и импортируется в основном энергетический уголь (поставлено 16,1 млн т) и немного коксующегося (0,7 млн т). Практически весь уголь завозится из Казахстана (поставлено 16,6 млн т).

С учетом завоза и импорта энергетического угля на российские электростанции поставлено 79,1 млн т угля (на 1,6 млн т, или на 2\% выше, чем годом ранее). С учетом завоза и импорта коксующегося угля на нужды коксования поставлено 26,2 млн т (на 0,5 млн т, или на 2\% выше, чем годом ранее).

Всего на российский рынок в январе-сентябре 20172. поставлено с учетом завоза и импорта 138 млн т, что на 4,3 млн $m$, или на 3\% больше, чем годом ранее.

При этом доля завозимого (в том числе импортного) угля в поставках угля на российский рынок составляет $12 \%$.

Поставка угля на российский рынок с учетом завоза (импорта), млн m

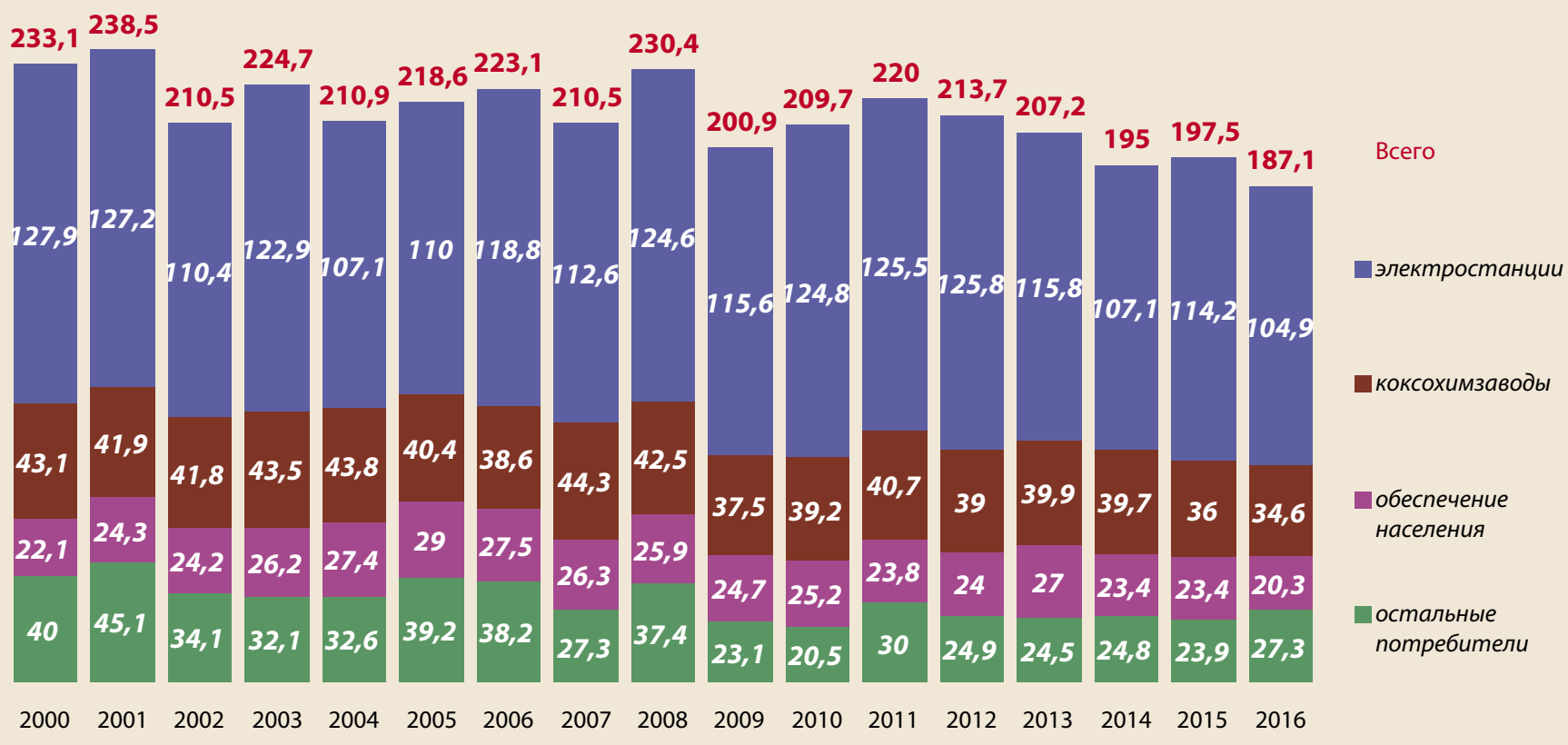




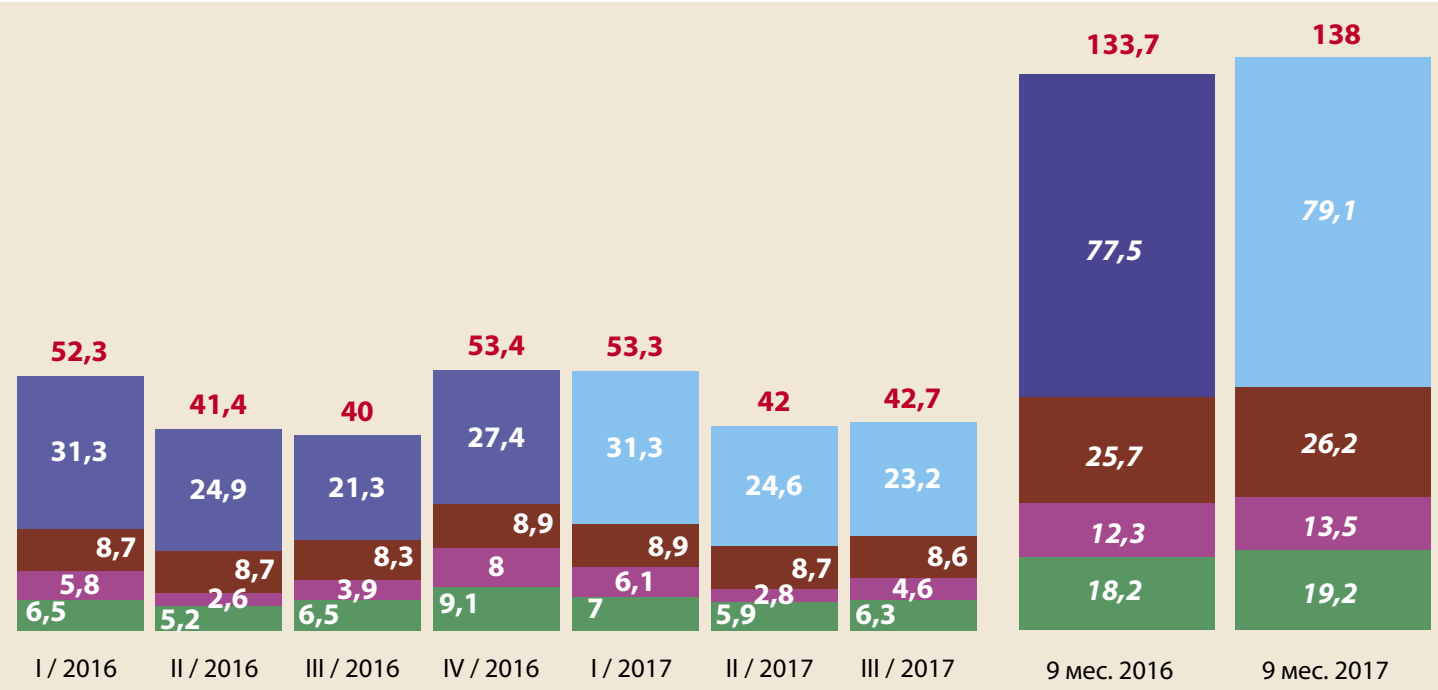

\section{ЭКСПОРТ УГЛя}

Объем экспорта российского угля в январе-сентябре 2017 2., по отчетным данным угледобывающих компаний (по данным ФГБУ «ЦДУТЭК»), составил 140,3 млн m, по сравнению с аналогичным периодом 2016 г. он увеличился на 19,4 млн т, или на 16\%.

Экспорт составляет 54\% в поставках российского угля. Основная доля экспорта приходится на энергетические угли 128,4 млн т (92\% общего экспорта углей), доля коксующихся углей (11,9 млн т) в общем объеме внешних поставок составила 8\%. Основным поставщиком угля на экспорт является Сибирский ФО (поставлено 123,7 млн т, что составляет $88 \%$ общего экспорта), а среди экономических районов - Западно-Сибирский (поставлено 108,6 млн т, или 77\% общего экспорта), в том числе доля Кузбасса - 72\% общего экспорта (поставлено 101,4 млн т).

Из общего объема экспорта основной объем угля отгружался в страны дальнего зарубежья - 129,2 млн т (92\% общего объема экспорта), что на 19 млн т больше, чем годом ранее. В страны ближнего зарубежья поставлено 11,1 млн т (8\% общего объема экспорта), что на 0,36 млн т больше, чем в январе-сентябре 2016 г.

В течение января-сентября 2017 г. отмечались небольшие колебания цен на энергетический уголь как в сторону снижения, так и повышения, в пределах 3-7\%. В сентябре 2017 г. (по сравнению спредыдущим месяцем) зафиксирован рост цен на энергетический уголь на торговых площадках: в порту Ричардз Бей (ЮАР) - на 4,6\%, Ньюкасл (Австралия) - на 2,1\%, в восточных портах Японии - на 7,6\%, в порту Восточный (Россия) - на 5,2\%.
Удельный вес экономических районов России в экспортных поставках угля в январе-сентябре 2017 г.

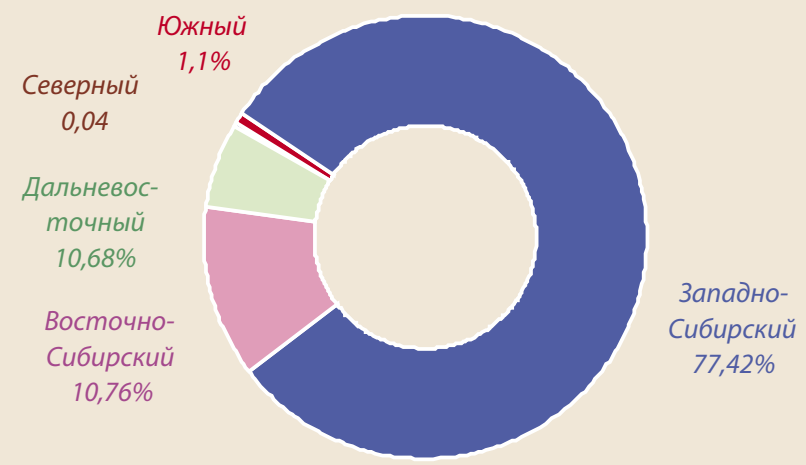

Экспортные цены на энергетические угли, дол. США за тонну (по данным Металл Эксперт)

\begin{tabular}{|c|c|c|c|c|c|c|c|c|c|}
\hline \multirow{2}{*}{ Регионы и порты } & \multicolumn{9}{|c|}{2017} \\
\hline & янВ. & фев. & март & anp. & май & июнь & июль & aвr. & сент. \\
\hline СИФ Европа (Амстердам, Роттердам, Антверпен) & 91 & 83 & 77 & 75 & 75 & 79 & 84 & 85 & 92 \\
\hline ФОБ Ричардз Бей (ЮАР) & 87 & 83 & 80 & 78 & 75 & 77 & 84 & 87 & 91 \\
\hline ФОБ Ньюкасл (Австралия) & 85 & 77 & 80 & 84 & 75 & 83 & 88 & 97 & 99 \\
\hline СИФ Япония & 89 & 89 & 87 & 90 & 74 & 84 & 91 & 92 & 99 \\
\hline ФОБ Восточный (Россия) & 88 & 81 & 83 & 84 & 76 & 82 & 84 & 96 & 101 \\
\hline
\end{tabular}


Динамика чен на энергетический уголь СИФ Европа (APA), дол. США за тонну

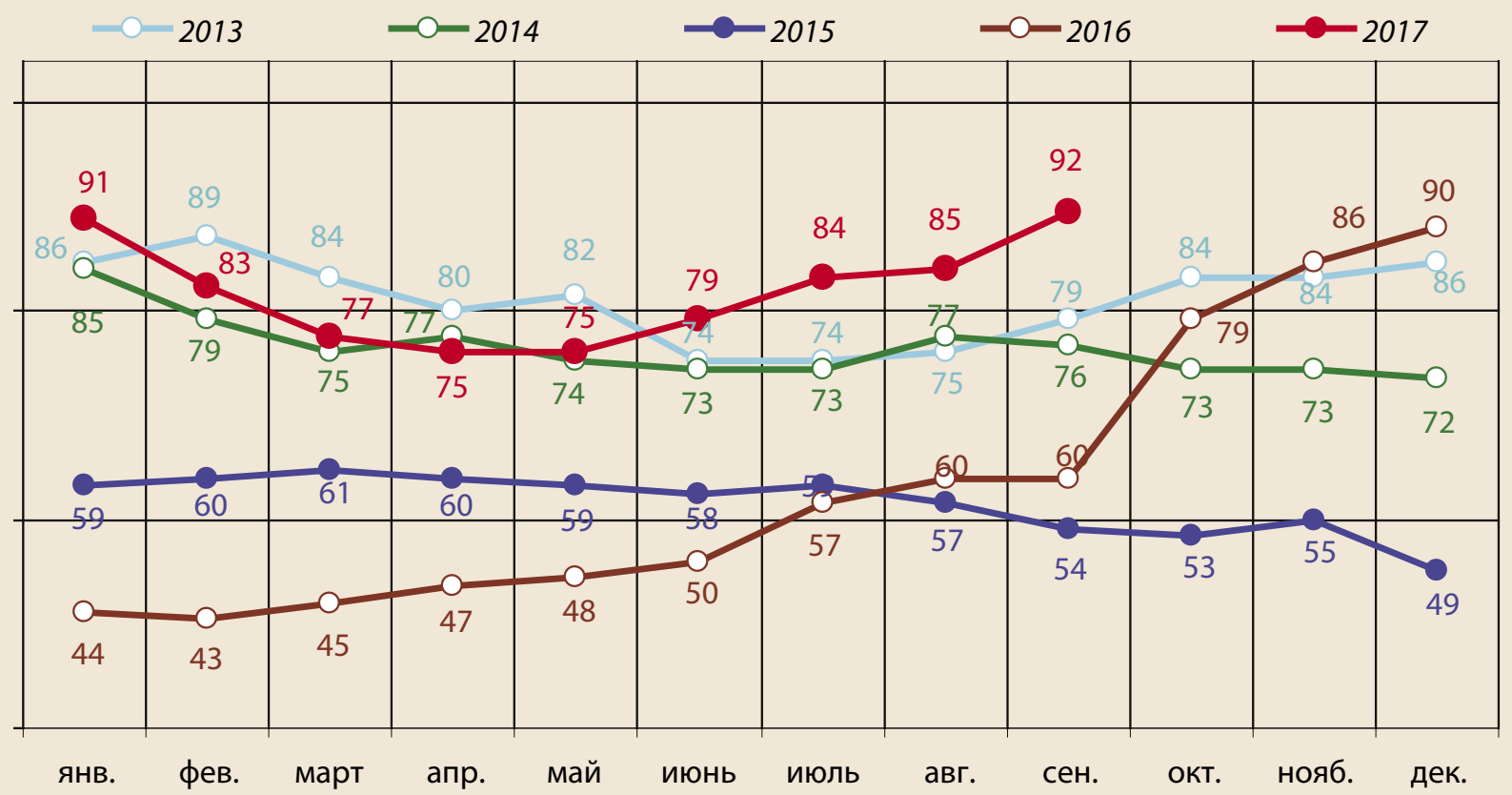

Общий объем вывезенного российского угля в январесентябре 2017 г., по данным ОАО «РЖД», составил 142,4 млн т, в том числе через морские порты отгружено 97,6 млн $m$ (68,5\% общего объема вывоза).

Удельный вес поставок российского угля в январесентябре 2017 г. по сравнению с аналогичным периодом 2016 г. увеличился через порты балтийского направления на 3,7\% и южного направления - на 0,8\%, снижение отмечено в портах северного направления на $0,4 \%$ и восточного - на 4,2\%.

Структура поставок российского угля через порты и погранпереходы в январе-сентябре 2013-2017 г2.

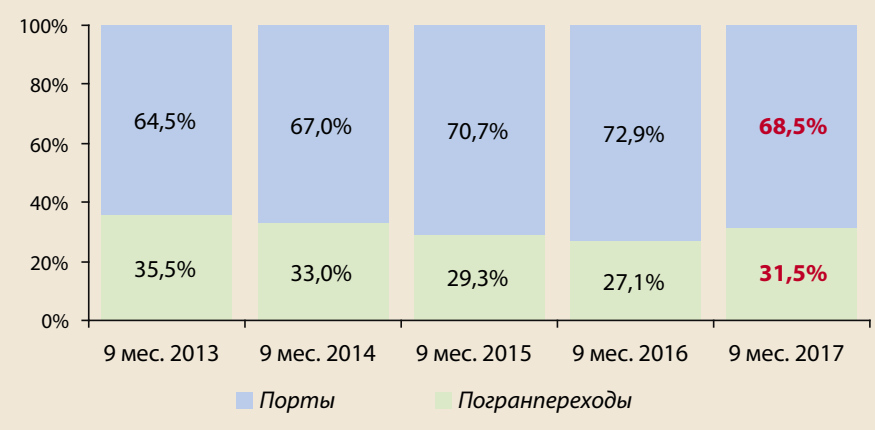

Структура поставок российского угля через порты в январе-сентябре 2013-2017 г2., \%

\begin{tabular}{|c|c|c|c|c|c|}
\hline $100 \%$ & $15,9 \%$ & $15,0 \%$ & $13,3 \%$ & $12,7 \%$ & $12,3 \%$ \\
\hline $80 \%$ & $22,9 \%$ & $21,6 \%$ & $22,5 \%$ & $22 \%$ & $25,7 \%$ \\
\hline $60 \%$ & $7,4 \%$ & $6,0 \%$ & $6,2 \%$ & $6,3 \%$ & $7,2 \%$ \\
\hline $\begin{array}{l}40 \% \\
20 \%\end{array}$ & $53,8 \%$ & $57,4 \%$ & $57,9 \%$ & $59 \%$ & $54,8 \%$ \\
\hline & 9 мес. 2013 & 9 мес. 2014 & 9 мес. 2015 & 9 мес. 2016 & 9 мес. 2017 \\
\hline \multicolumn{3}{|c|}{ CEBEP } & \multicolumn{2}{|c|}{ ЮГ (ЧЕРНOE MOРЕ) } & \\
\hline \multicolumn{3}{|c|}{ ЗАПАД (БАЛТИКА) } & \multicolumn{2}{|c|}{ ВОСТОК } & \\
\hline
\end{tabular}

Объемы поставок угля через российские порты в январесентябре 2017 г. по сравнению с аналогичным периодом 2016 г. увеличились на 13,5 млн т, или на 16,1\%. Увеличение поставок отмечено через все порты, в том числе через порты западного направления (Балтика) - на 6,63 млн т (+35,9\%), восточного направления - на 3,9 млн т (+7,9\%), южного направления - на 1,65 млн т (+31\%) и северного направления - на 1,33 млн т (+12,5\%).

объемы поставок российского угля через пограничные переходы, по данным ОАО «РЖД», в январесентябре 2017 г. по сравнению с аналогичным периодом 2016 г. увеличились на 43,7\% и составили 44,8 млн m (31,5\% общего объема вывоза).

Поставка российского угля сухопутным путем осуществляется в основном через пограничные переходы Центрального, Северо-Западного и Дальневосточного федеральных округов (около 92,4\% общей поставки сухопутным путем за январь-сентябрь 2017 г.). Увеличились, если сравнивать с аналогичным периодом прошлого года, поставки через пограничные переходы Соловей (+28,8\%), Суземка (+84,4\%), Красное (+66,1\%), Рудня (+35,3\%), Мамоново (+67,3\%), Заречная (+45,9\%), Веселое $(+87,8 \%)$, Мыс Астафьева $(+8,4 \%)$, Хасан $(+71,4 \%)$, Камыш-Экспорт (+58,8\%). Более чем в 8,5 раза увеличились объемы перевалки через Забайкальск и в 5,5 раза через пограничный переход Гродеково. Снизились объемы экспорта российского угля через пограничные переходы Злынка (-10\%), Кулунда $(-40,2 \%)$ и Локоть $(-11,5 \%)$.

В России крупнейшими компаниями-экспортерами угля выступают: АО «СУЭК», ОАО «УК «Кузбассразрезуголь», АО ХК «СДС-Уголь», ОАО «Мечел-Майнинг», ПАО «Кузбасская Топливная Компания» и др.; они же являются и крупнейшими поставщиками энергетических углей на экспорт. Основными поставщиками коксующихся углей на экспорт являются: АО ХК «Якутуголь» (ОАО «МечелМайнинг»), АО «СУЭК-Кузбасс», ООО «Распадская УК» (ЕВРАЗ), ОАО «УК «Кузбассразрезуголь» (УГМК), ООО «УК «ЕВРАЗ Междуреченск» и др. 
Экспорт российского угля в январе-сентябре 2017 г., тыс. т

(по отчетным данным угледобывающих компаний)

\begin{tabular}{|c|c|c|c|c|c|}
\hline $\begin{array}{c}\text { Крупнейшие } \\
\text { экспортеры угля }\end{array}$ & 9 мec. 2017 & $\begin{array}{c}+/- \\
\text { к } 9 \text { мeс. } 2016\end{array}$ & $\begin{array}{c}\text { Крупнейшие } \\
\text { страны-импортеры* }\end{array}$ & 9 мec. 2017 & $\begin{array}{c}+/- \\
\text { к } 9 \text { мес. } 2016\end{array}$ \\
\hline$A О$ «СУЭК» & 34708 & 2471 & Япония & 26959 & 2010 \\
\hline ОАО «УК «Кузбассразрезуголь» & 22639 & 1062 & Великобритания & 20421 & 2996 \\
\hline АО ХК «СДС-Уголь» & 17101 & 5621 & Китай & 15196 & 4897 \\
\hline ОАО «Мечел-Майнинг»: & 7684 & -187 & Республика Корея & 10746 & 1185 \\
\hline - АО ХК «Якутуголь» & 3748 & 88 & Украина & 6723 & -795 \\
\hline - ПАО «Южный Кузбасс» & 2851 & -278 & Финляндия & 5414 & 159 \\
\hline - ООО «Эльгауголь» & 1085 & 3 & Польша & 5087 & 2188 \\
\hline ПАО «Кузбасская ТК» & 6240 & 738 & Турция & 4885 & 2193 \\
\hline ООО «Разрез Кийзасский» & 4778 & 1908 & Латвия & 3378 & 874 \\
\hline АО «Сибирский Антрацит» & 4763 & 1671 & Румыния & 1590 & 1259 \\
\hline ООО «Ресурс» & 4494 & 483 & Бельгия & 1578 & 611 \\
\hline ООО «Распадская УК» & 4485 & 62 & Швейцария & 1380 & 66 \\
\hline ООО «ВГК» (УМП Шахтерск) & 3817 & 1197 & Индия & 1168 & -443 \\
\hline ООО «УК Талдинская» & 2574 & 1223 & Испания & 980 & -67 \\
\hline ЗАО «Стройсервис» & 2098 & 882 & Словакия & 808 & -130 \\
\hline АО «Русский Уголь» & 2066 & 471 & Таиланд & 598 & 485 \\
\hline ЗАО «Талтэк» & 1955 & 550 & Филиппины & 568 & 308 \\
\hline ООО «УК «ЕВРАЗ Междуреченск» & 1682 & 32 & Болгария & 473 & 48 \\
\hline ООО «Разрез «Бунгурский-Северный» & 1290 & 144 & Швеция & 410 & -425 \\
\hline ЗАО «Шахта Беловская» & 1260 & 215 & Тайвань & 337 & 170 \\
\hline
\end{tabular}

* Без учета части экспортных данных ООО «Ресурс» и некоторых филиалов АО «СУЭК».

Основные экспортеры российского угля в январе-сентябре 2017 г., тыс. $m$ (всего экспортировано 140287 тыс. m)

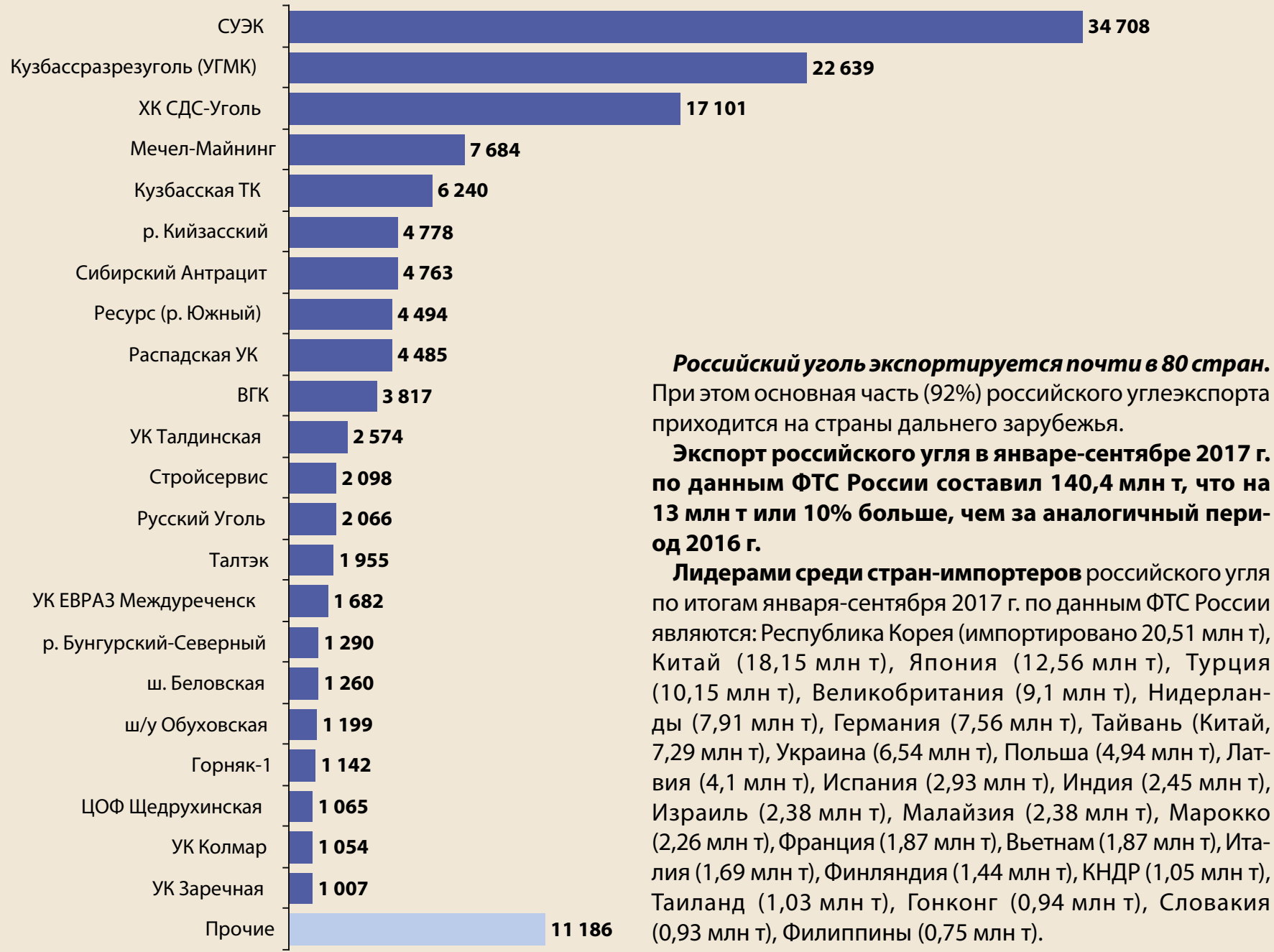


Динамика экспорта и завоза (импорта) угля по России, млн т

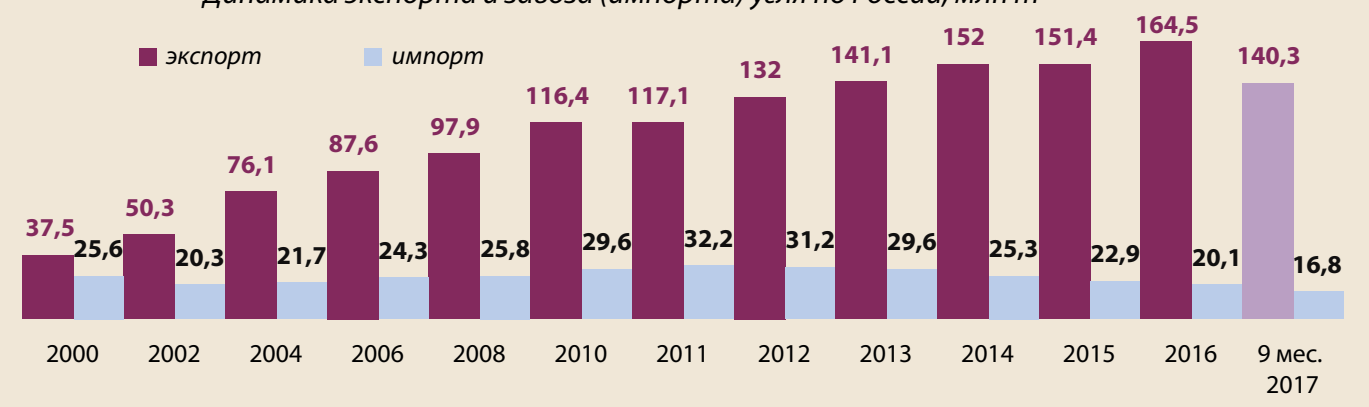

Доля экспорта в объемах поставки российского угля, \%

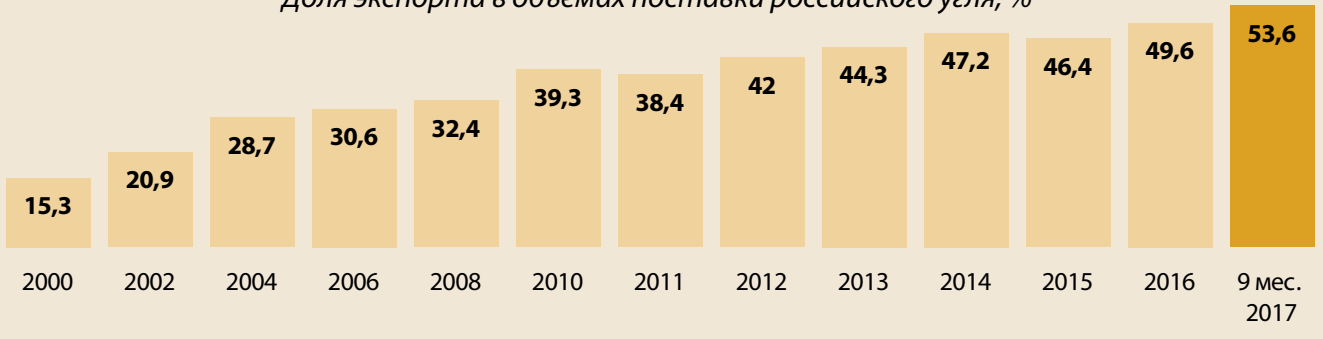

Соотношение завоза к экспорту угля составляет 0,12

\section{PEЗЮME}

Основные показатели работы угольной отрасли России за январь-сентябрь 2017 г.

\begin{tabular}{|c|c|c|c|}
\hline Показатели & $\begin{array}{l}9 \text { Mec. } \\
2017\end{array}$ & $\begin{array}{l}9 \text { Mec. } \\
2016\end{array}$ & $\begin{array}{c}\text { К уровню } \\
9 \text { мес. 2016, \% }\end{array}$ \\
\hline Добыча угля, по данным Росстата, всего, тыс. т & 302394 & 281950 & 107,3 \\
\hline Добыча угля, по данным ЦДУ ТЭК, всего, тыс. т: & 301070 & 283921 & 106,0 \\
\hline - подземным способом & 80819 & 78638 & 102,8 \\
\hline - открытым способом & 220251 & 205283 & 107,3 \\
\hline Добыча угля на шахтах, тыс. т & 81273 & 80070 & 101,5 \\
\hline Добыча угля на разрезах, тыс. т & 219797 & 203851 & 107,8 \\
\hline Добыча угля для коксования, тыс. т & 65680 & 67877 & 96,8 \\
\hline Переработка угля, всего тыс. т: & 145396 & 139603 & 104,1 \\
\hline - на фабриках & 141302 & 136499 & 103,5 \\
\hline - на установках механизированной породовыборки & 4094 & 3104 & 131,9 \\
\hline Поставка российских углей, всего тыс. т & 261540 & 239661 & 209,1 \\
\hline - из них потребителям России (по данным ЦДУТЭК) & 121253 & 118734 & 102,1 \\
\hline - экспорт угля (по данным ЦДУТЭК) & 140287 & 120927 & 116,0 \\
\hline Экспорт угля, по данным ФТС России, тыс. т & 140434 & 127430 & 110,2 \\
\hline Завоз и импорт угля, тыс. т & 16809 & 14985 & 112,2 \\
\hline Поставка угля потребителям России с учетом завоза и импорта, тыс. т & 138062 & 133719 & 103,2 \\
\hline Средняя численность работников предприятий угледобычи и переработки, чел. & 139657 & 139975 & 99,8 \\
\hline Среднесписочная численность работников по основному виду деятельности, чел. & 134318 & 134675 & 99,7 \\
\hline $\begin{array}{l}\text { Среднесписочная численность рабочих по добыче угля (квартальная, } \\
\text { предварительные данные), чел.: }\end{array}$ & 86789 & 87166 & 99,6 \\
\hline - на шахmax & 38057 & 38478 & 98,9 \\
\hline - наразрезах & 48732 & 48688 & 100,1 \\
\hline Среднемесячная производительность труда рабочего по добыче угля (квартальная), т & 322,4 & 307,0 & 105,0 \\
\hline - на шахmax & 221,8 & 208,7 & 106,3 \\
\hline -наразрезах & 401,0 & 384,8 & 104,2 \\
\hline Среднемесячная заработная плата одного работника, руб. & 50348 & 46225 & 108,9 \\
\hline Среднесуточная добыча угля из одного действующего очистного забоя, т & 4730 & 4658 & 101,5 \\
\hline Среднесуточная добыча угля из одного комплексно-механизированного забоя, т & 5052 & 4910 & 102,9 \\
\hline Проведение подготовительных выработок, тыс. м & 302 & 272 & 111,3 \\
\hline Вскрышные работы, тыс. куб. м & 1430618 & 1244247 & 115,0 \\
\hline
\end{tabular}

UDC 622.33(470):658.155 @ I.G. Tarazanov, 2018

ANALYTICAL REVIEW

ISSN 0041-5790 (Print) • ISSN 2412-8333 (Online) • Ugol' - Russian Coal Journal, 2018, № 1, pp. 18-32

Title

RUSSIA'S COAL INDUSTRY PERFORMANCE

FOR JANUARY - SEPTEMBER, 2017

DOI: http://dx.doi.org/10.18796/0041-5790-2018-1-18-32

Author

Tarazanov I.G.

${ }^{1}$ Ugol' Journal Edition LLC, Moscow, 119049, Russian Federation

\section{Authors' Information}

Tarazanov I.G., Mining Engineer, General Director, Deputy Chief Editor of the Russian Coal Journal (Ugol'), e-mail: ugol1925@mail.ru

\section{Abstract}

The paper provides an analytical review of Russia's coal industry performance for JanuarySeptember, 2017 on the basis of statistical, technical \& economic and production figures. The review contains diagrams, tables and comprehensive statistical data.

Keywords

Coal production, Economy, Efficiency, Coal processing, Coal market, Supply, Coal exports and imports.

\section{References}

1. Tarazanov I.G. Itogy raboty ugol'noy promishlennosty Rossii za yanvar - dekabr 2016 [Russia's coal industry performance for January - December, 2016]. Ugol' - Russian Coal Journal, 2017, no. 3, pp. 36-50. doi: 10.18796/0041-5790-2017-3-36-50. 


\section{На шахте имени С.М. Кирова АО «СУЭК-Кузбасс» установлен новый рекорд добычи угля}

На шахте имени С.М. Кирова АО «СУЭК-Кузбасс» 14 декабря 2017 г. установлен новый исторический рекорд не только предприятия, но и всегоЛенинского (Кольчугинского) рудника - с начала года выдано на-гора 7 млн т угля.

Основной вклад в общий успех шахты внесли очистные бригады Олега Германа и Юрия Солдатенко. Отрабатывая пласты мощностью чуть больше 2 м, каждый из коллективов выдал на-гора с начала 2017 года более 3 млн т угля. При этом установлено несколько рекордов месячной добычи. Так, бригада Олега Германа добыла в октябре на пласту «Болдыревский» 450 тыс. т угля, бригада Юрия Солдатенко в апреле на пласту «Поленовский» - 318 тыс. т. Абсолютный рекорд месячной добычи в целом по предприятию теперь составляет 807,6 тыс. т угля.

Генеральный директор АО «СУЭККузбасс» Евгений Ютяев в приветственном адресе отметил сплоченность и высокий профессионализм всего коллектива шахты, умело внедряющего самые современные, эффективные и безопасные технологии подземной угледобычи. Лучшие сотрудники предприятия награждены корпоративными наградами.

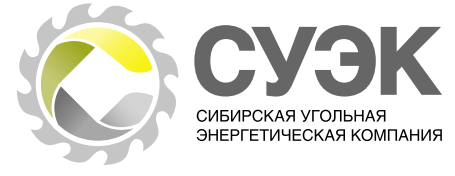

Одним из главных слагаемых сегодняшних успехов шахты имени С.М. Кирова является продуманная инвестиционная политика. За последние пять лет на переоснащение предприятия СУЭК направила более 9 млрд руб. В числе приоритетных проектов уходящего года - приобретение 177 секций механизированной крепи FRS Glinik-12/26 производства Группы FAMUR (Польша).

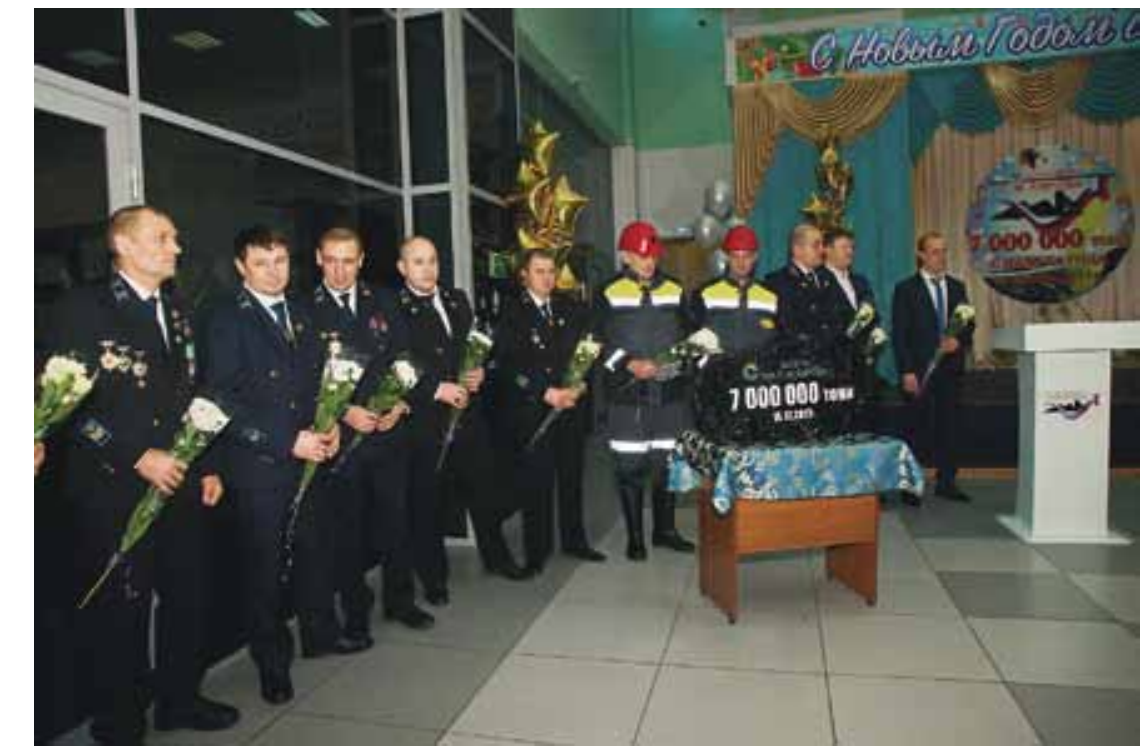

\section{СУЭК получила награду Минприроды за активную экологическую политику}

12 декабря 2017 г. в рамках V Всероссийского съезда по охране окружающей среды и выставки форума «ЭКОТЕХ» и заседания Федерального экологического совета под председательством министра природных ресурсов и экологии Российской Федерации Сергея Донского прошла церемония награждения компаний, показавших наилучшие результаты по реализации мероприятий, предусмотренных соглашениями в рамках Года экологии.

На церемонии было объявлено, что AO «Сибирская угольная энергетическая компания» (СУЭК) получила награду в номинации «Активная экологическая политика компании в Год экологии».

Обеспечение экологической безопасности, минимизация экологических рисков производства и охрана природы являются неотъемлемой частью страте- гии устойчивого развития СУЭК. Компания реализует комплекс мероприятий по охране воздушных ресурсов (дегазация шахт и утилизация метана), охране водных ресурсов (очистка сточных вод), энергоэффективности, рекультивации земель и сохранению биоразнообразия. В Год экологии СУЭК подписала десять соглашений о взаимодействии на общую сумму более 6 млрд руб. Среди партнеров компании - Министерство природных ресурсов и экологии РФ, Росприроднадзор, администрации регионов, где работают предприятия СУЭК.

Деятельность СУЭК в сфере экологии неоднократно отмечена профессиональным сообществом - компания является, в частности, победителем национальной премии EraEco (при поддержке UNIDO и Минприроды РФ), Evolution Awards, Eco Best Award. 


\section{О возможности использования мобильных \\ робототехнических летательных аппаратов}

\section{при выполнении оперативного плана}

\section{ликвидации аварии на шахтах}

DOI: http://dx.doi.org/10.18796/0041-5790-2018-1-34-38

\author{
КИМ Максим Ленсович \\ Главный технолог $\mathrm{AO}$ «СУЭК», \\ 115054, г. Москва, Россия, \\ e-mail:kimml@suek.ru
}

\section{РОДИЧЕВ Андрей Сергеевич}

Начальник управления

технического обеспечения производства $A O$ «СУЭК», 115054, г. Москва, Россия,

e-mail: rodichevas@suek.ru

\section{ПЕВЗНЕР Леонид Давидович}

Доктор техн. наук, действительный член АГН, профессор Московского технологического университета «МИРЭА», 119435, г. Москва, Россия, e-mail:Ipevzner@msmu.ru

\section{ПЛАТОНОВ Александр Константинович}

Доктор техн. наук,

Профессор Института прикладной

математики им. М.В. Келдыша РАН, 125047 , г. Москва, Россия

Описан способ применения мобильных робототехнических летательных аппаратов для идентификации разрушений и анализа состава рудничной атмосферы на аварийном участке в шахте. Приведены оценки требуемых характеристик летательных средств, способных функционировать в шахтных условиях.

Ключевые слова: шахта, авария, план ликвидачии аварии, спасатель, беспилотный летательный аппарат.

\section{ВВЕДЕНИЕ}

Наиболее опасной из сфер трудовой деятельности человека являются подземные горные работы. Они требуют постоянного внимания к обеспечению безопасности горных работ. Поэтому применение робототехнических систем и мобильных роботов для спасения людей актуально уже сейчас.

В шахтах возможны аварии техногенного и природного происхождения. Техногенные аварии возникают вследствие нарушения технологических процессов. В возник- новении и развитии природных аварий преобладающее значение имеют природные явления. Среди аварий доминируют быстро развивающиеся во времени - экзогенные пожары, взрывы, обрушения, внезапные выбросы горных пород, газа, пожары от самовозгорания горной массы. Для устранения этих аварий требуются применение специального оборудования и привлечение ВГСЧ.

При возникновении любого рода аварий в шахтах существуют проблемы эффективной организации горноспасательных работ, которые имеют большое значение для быстрейшего оказания помощи застигнутым аварией в шахте людям и ликвидации последствий аварии. Особенно четко и быстро должны быть организованы горноспасательные работы в самый начальный период времени возникновения аварии, когда своевременное, верно принятое и быстро выполненное решение может спасти многих находящихся в шахте людей и свести к минимуму ущерб от аварии.

Горноспасательные работы состоят из разведки зоны аварии, вывода застигнутых аварией людей, оказания им первой помощи и действий по локализации и ликвидации последствий аварии [1]. Задачей проведения разведки являются оценка и анализ рудничной обстановки на аварийном участке. Во время ликвидации аварий часто случаются ситуации, когда ВГСЧ в силу внешних условий - отсутствие видимости или высокой температуры не могут продвинуться по выработке для выполнения мероприятий плана ликвидации аварии по локализации аварии и спасению людей. В такой ситуации для сохранения жизни сотрудников ВГСЧ, отвечающих за разведку рудничной обстановки, целесообразно рассмотреть возможность использования робототехнических средств разведки.

Вопросам использования робототехнических средств в условиях шахты посвящена работа [2]. В ней приведены результаты экспериментальных исследований возможности применения беспилотных летательных аппаратов в подземных условиях. Выполнена оценка влияния электромагнитных свойств массива горных пород на передачу электромагнитного сигнала и параметры датчиков. Рассмотрено влияние рудничной атмосферы и воздушных потоков на полетные характеристики беспилотных летательных аппаратов и установлены основные требования к их навигационному оборудованию для бесперебойной работы в шахтных условиях.

В рассматриваемой статье испытания проводились в рудной шахте, для угольных шахт требуются иные реше- 
ния. Для решения задачи информационной разведки в условиях аварийной шахты наиболее эффективным способом представляется использование беспилотных летательных аппаратов (БПЛА) во взрывобезопасном исполнении. В наземных условиях техника БПЛА в последнее время получила широкое развитие [3, 4, 5, 6]. Данная работа посвящена анализу возможностей применения подобной техники под землей. Работа содержит анализ рудничных условий и обстоятельств выполнения разведывательных операций в аварийных шахтах для формирования требований к разработке подземных БПЛА.

\section{СЦЕНАРИЙ АВАРИЙНЫХ РАБОТ \\ С ИСПОЛЬЗОВАНИЕМ БПЛА}

Промоделируем следующую ситуацию, выделяя курсивом обстоятельства, имеющие значение для упомянутого анализа.

Горному диспетчеру шахты поступила информация, что в путевом стволе задымление. Горный диспетчер ввел в действие план ликвидации аварии по виду аварии «Пожар» и вызвал ВГСЧ. По результатам телефонного обзвона было выявлено, что без связи остались конвейерный штрек и забой сбойки между стволами, а также то, что кро- ме дыма ощущались еще и толчки. На основании этих данных было сделано предположение, что в одной из этих выработок произошел взрыв.

Прибывшие на шахту сотрудники ВГСЧ приступили к спуску по вентиляционному стволу. В районе вентиляционного штрека вентиляционный ствол был пересыпан, и сотрудники по сбойке перешли на конвейерный ствол. Спустившись по конвейерному стволу, отделения по сбойке перешли на путевой ствол. Далее отделения ВГСЧ приступили к спуску по путевому стволу. Спустившись по путевому стволу до конвейерного штрека, прошли 200 м в сторону тупика. Выполненные измерения показали, что содержание метана в выработке превышает 6\%, кислорода-меньше 13\%, концентрация угарного газа превышает 3\%, температура приближается к $30^{\circ} \mathrm{C}$, видимость нулевая. Из-за этих условий взрывоопасной атмосферы в аварийной выработке ее дальнейшее обследование прекращено решением руководства ВГСЧ. На путевом и конвейерном стволах возведены взрывоустойчивые перемычки, как показано на рис. 1, и отделения ВГСЧ выведены на поверхность.

В рассмотренной ситуации для использования робототехнических летательных аппаратов-возможны следующие варианты:

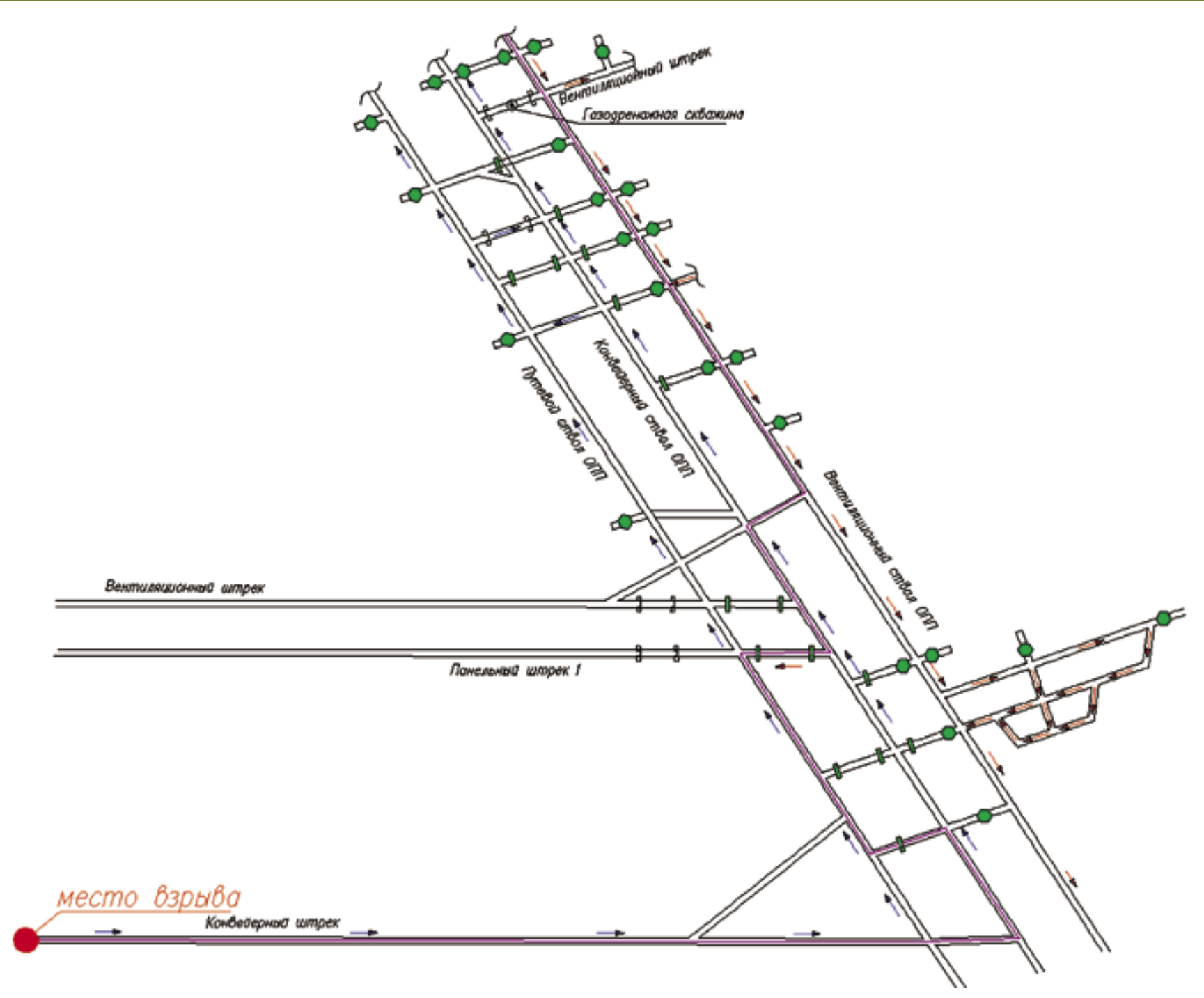

Puc. 1. Схема шахтных выработок и путь движения (красная линия) отделения ВГСЧ

Fig. 1. Mine workings diagram and rescue brigade path (red line) 
- отделение ВГСЧ, пройдя по конвейерному стволу и еще до начала спуска по путевому стволу, запускает специально «обученный» под конкретную шахту, дистанционно управляемый летательный annapam, оснащенный датчиками температуры, кислорода, метана, тепловизорами и дальномерами. Летательный аппарат, преодолевая препятствия, должен долететь до места возникновения аварии в конвейерном штреке и передать на пульт управления изображение и данные о параметрах рудничной обстановки для дальнейшего принятия решения. Для обеспечения этой операции разведывательного ДУ БПЛА другой специально «обученный» под конкретную шахту автоматический или Әистанционно управляемый БПЛА или другие в требуемом для данной шахты количестве летательные апnараты, запускаемые одновременно или последовательно, должны обеспечить установку средств радиосвязи с БПЛА (радиопередатчиков с навигационными маяками-ориентирами) каждые 100-200 м прямой радио-видимости и на всех местах ее прекращения на пути разведывательного БПЛА от места управления им и до места аварии;

- при введении в действие плана ликвидации аварии по виду аварии «Пожар» по вентиляционному стволу в кратчайшее время вылетает автономный робототехнический летательный annapam, и, разбрасывая радиодатчики каждые 100-200 м, долетает до сопряжения выработки с местом возникновения аварии. Если температура в выработке находится в допустимом диапазоне, то робототехнический летательный аппарат долетает до места возникновения аварии и передает данные по выстроенной сети. Если температура превышает критическую, то летательный аппарат останавливается в месте сопряжения и становится стационарным передающим устройством;

- в случае если руководитель ликвидации аварии и руководитель горноспасательных работ принимают решение о затоплении нижних частей путевого, конвейерного и вентиляционного стволов до подтопления устья конвейерного штрека, то летательный аппарат, оставшийся в зоне возникновения аварии, продолжит передавать информацию о рудничной обстановке. Тем самым у руководителя ликвидации аварии и руководителя горноспасательных работ будет достаточно полная информация о составе атмосферы, получаемая как с датчиков у устьев стволов, так и с выстроенной робототехнической сенсорной сети.

\section{УСЛОВИЯ ШАХТЫ,}

\section{ВЛИЯЮЩИЕ НА КОНСТРУКЦИЮ ШАХТНОГО БПЛА}

Параметры современных угольных шахт их типовые и экстремальные значения:

- максимальные размеры по простиранию $S$ и по падению Н отечественных шахтных полей составляют величины $\max S=12$ кM, $\operatorname{maxH}=7$ кM;

- поперечные размеры горных выработок - не менее 4 м по ширине или 3 м по высоте;

- характерные размеры отдельных частей участков шахты лежат в следующих пределах:

- наклонные вентиляционные стволы: 800-1500 м;

- наклонные путевые и конвейерные стволы:800-1500 м;

- штреки: 200-5000 м;

- лавы: 100-400 м;
• расстояния прямой видимости шахтных штреков лежат в пределах: 10-400 м;

- скорости свежей и исходящей вентиляционных струй воздуха: 0,25-15 м/с;

- температуры поверхности горных выработок:

- в районе аварии: до $200^{\circ} \mathrm{C}$;

- вне района аварии: -6 - + 26 (норма);

- влажность шахтной атмосферы: 65-100\%;

• количество пыли в шахтной атмосфере: 10 (в норме) $15 \mathrm{Mr} / \mathrm{M}^{3}$.

Приведенные параметры шахт являются параметрами операционной среды рассматриваемого шахтного робота. Они позволяют определить ожидаемые конструктивные параметры БПЛА и способы его использования.

\section{АНАЛИЗ ОБСТОЯТЕЛЬСТВ ПРИМЕНЕНИЯ ИНФОРМАЦИОННЫХ СРЕДСТВ}

Наиболее важные эксплуатационные параметры БПЛА связаны с его функцией обеспечения сотрудников ВГСЧ информацией о физическом состоянии аварийных областей горных выработок и, возможно, живых или раненых людей в них. Для оценки технической возможности реализации этой функции с помощью БПЛА нужно получить ответы на следующие вопросы:

- какими средствами должен быть оснащен БПЛА;

- каковы должны быть техническиехарактеристики БПЛА;

- каковы должны быть средства управления движением БПЛА?

Ответ на первый вопрос достаточно очевиден, пока речь не идет о втором вопросе: прежде всего необходимы видеоданные о происшедших разрушениях, данные шахтных газоанализаторов и средства установления связи с шахтерами, попавшими в беду. В качестве таких средств в условиях обрушений следует прежде всего рассматривать акустические средства.

Для ответа на второй вопрос о требуемых технических возможностях БПЛА нужно оценить весовые, габаритные характеристики датчиков информационного оснащения БПЛА, средств акустической связи и параметры их энергопотребления. Для получения оценки параметров полезного груза БПЛА был проведен анализ отечественных и зарубежных упомянутых элементов. Полученные достижимые в настоящее время параметры ожидаемой комплектации летательного аппарата показаны в таблице.

\section{Параметры информационных средств} шахтного БПЛА

\begin{tabular}{l|c|}
\multicolumn{1}{c|}{ Прибор } & Масса, r \\
\hline Видеокамера & 59 \\
\hline Датчик температуры & 100 \\
\hline Датчик метана & 100 \\
\hline Датчик углекислого газа & 100 \\
\hline Датчик кислорода & 100 \\
\hline Микрофон & 50 \\
\hline Динамик & 50 \\
\hline
\end{tabular}

Из приведенной таблицы видно, что требуемая грузоподъемность БПЛА с полным комплектом приведенных средств оказывается не менее 559 г.

Эти довольно трудные для реализации требования можно уменьшить, если газоанализаторы, имеющие максималь- 
ный вес датчиков сделать стационарными и доставлять их на место отдельными рейсами БПЛА. Заметим, что поскольку движение БПЛА в стволе происходит вниз, то грузоподемность при рейсе «Туда» в исходящем потоке ствола может быть выше на допустимую скорость соударения с учетом парусности. В ряде случаев это может оказаться полезным.

Ответ на вопрос о способах управления БПЛА пока оставляем без комментариев, поскольку в первом приближении у существующих БПЛА эти вопросы уже решены с использованием носимого ноутбука и двух джойстиков. Следует отметить одно обстоятельство, отличающее шахтные БПЛА от обычных: оператор должен осматривать объекты на малом расстоянии от них. Это требует стабильной «неподвижности» БПЛА с хорошей дискретностью управления его угловым положением.

\section{ТРЕБУЕМЫЕ ХАРАКТЕРИСТИКИ И ОСНАЩЕНИЕ РОБОТОТЕХНИЧЕСКОГО ЛЕТАТЕЛЬНОГО АППАРАТА}

Анализ приведенного достаточно типового сценария использования БПЛА в операционном окружении и условиях аварийной шахты позволяет сделать следующие выводы относительно требований к устройству БПЛА:

- электрические устройства шахтного БПЛА - двигатели, видеокамера, датчики информации, радиосредства и электронные блоки должны быть исполнены в варианте взрывозащиты Категории (IIC) I, Уровня 1;

- конструкция БПЛА и его электронные и сенсорные элементы должны быть выполнены в варианте влагопыли защиты IP 66;

- конструкция БПЛА и его электронные и сенсорные элементы должны сохранять работоспособность при температуре окружения $+50^{\circ} \mathrm{C}$ в течение всего времени активного функционирования блока энергопитания и не менее 2/3 этого времени и при кратковременных воздействиях температуры до $+500^{\circ} \mathrm{C}$ для возможности пролетать сквозь пламя;

- сила тяги винтов БПЛА должна превышать ветровую нагрузку, образуемую потоком воздуха с температурой $25^{\circ} \mathrm{C}$ со скоростью $20 \mathrm{~m} / \mathrm{c}$;

- скорость полета должна регулироваться в пределах 0-20 м/с, на малых скоростях - не более 1 см/с и иметь режим зависания;

- угловая скорость изменения направления оси камеры должна регулироваться в пределах 0-45\% при дискретности на малых скоростях не более $6 \%$ и иметь режим фиксации;

- в конструкции аппарата должно быть предусмотрено устройство захвата и освобождения несомого предмета по команде оператора или программно;

- для предотвращения столкновений и повреждений винтов летательный аппарат необходимо снарядить «защитой» с пределом прочности до $1400 \mathrm{H} /$ мм² $^{2}$ с высокими антикоррозийными свойствами (рис. 2).

\section{ЗАКЛЮЧЕНИЕ}

В работе предложено применение робототехнических летательных аппаратов для выполнения задач разведки обстановки после аварии в шахте. Предложена конструкция летательного аппарата, исследованы и определены его необходимые характеристики.

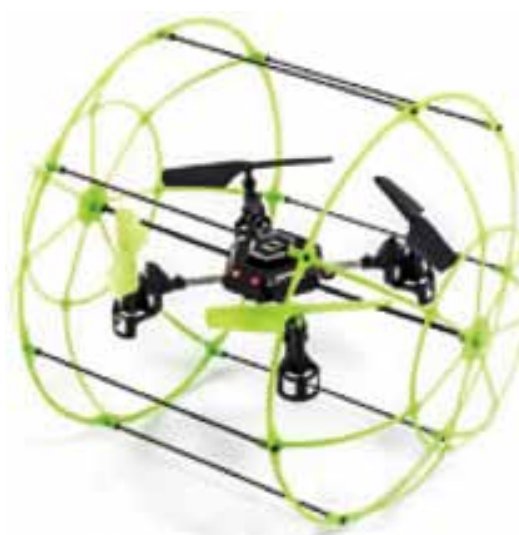

Puc. 2. Примерная конструкция летательного апnарата

Fig. 2. Tentative aircraft design

Подобные БПЛА нужны для временного воссоздания разрушенной инфраструктуры радиосвязи, доставки в район аварийной горной выработки датчика температуры и газоанализаторов, передачи зрительного изображения области разрушения и попыток установления связи с оставшимися в шахте людьми.

Таким образом, летательный аппарат при его создании обеспечивает решение следующих задач:

- автономная разведка обстановки в шахте после аварии;

- поиск места возникновения аварии;

- восстановление сети датчиков путем использования сенсорных сетей;

- оперативная передача данных о рудничной обстановке на поверхность в диспетчерскую;

- исключение прохода сотрудников ВГСЧ в аварийную зону для выполнения анализа газовоздушной среды и других операций.

\section{Список литературы}

1. Безопасность ведения горных работ и горноспасательное дело / К.З. Ушаков, Н.О. Каледина, Б.Ф. Кирин и др. М.: Изд-во Московского государственного горного университета, 2008. 487 с.

2. Конурин А.И., Денисова Е.В., Хмелинин А.П. Основные проблемы и перспективы применения беспилотных летательных аппаратов для обследования выработанного пространства при подземной разработке месторождений // Фундаментальные и прикладные вопросы горных наук. 2016. T. 1. № 3. С. 93-97.

3. Бондарев А.Н., Киричек Р.В. Обзор беспилотных летательных аппаратов общего пользования и регулирования воздушного движения БПЛА в разных странах // Информационные технологии и телекоммуникации. 2016. Т. 4. № 4. С. 13-23.

4. Разработка квадрокоптеров со специальными свойствами для проведения разведывательных операций / Д.Т. Рубин, В.Н. Конев, А.В. Стариковский, А.А. Шептунов // Спецтехника и связь. 2012. № 1.

5. Попов Н.И., Емельянова О.В., Яцун С.Ф. Моделирование динамики полета квадрокоптера // Вестник Воронежского института ГПС МЧС России. 2014.

6. Алгоритмы управления летающим роботом при слежении за подвижным объектом / Буй Ван Шон, А.Б. Бушуев, Г.М. Шмигельский и др. // Известия высших учебных заведений. Приборостроение. 2015. 
UDC 622.86:778.35 @ M.L. Kim, A.S. Rodichev, L.D. Pevzner, A.K. Platonov, 2018

ISSN 0041-5790 (Print) • ISSN 2412-8333 (Online) • Ugol' - Russian Coal Journal, 2018, № 1, pp. 34-38

Title

POSSIBILITY OF USING ROBOTIC FLYING SYSTEMS FOR SOLVING ACCIDENT LIQUIDATION OPERATING PLAN IN THE MINE

DOI: http://dx.doi.org/10.18796/0041-5790-2018-1-34-38

Authors'

Kim M.L. ${ }^{1}$, Rodichev A.S. ${ }^{1}$, Pevzner L.D. ${ }^{2}$, Platonov A.K. ${ }^{3}$

${ }^{1}$ SUEK, JSC, Moscow, 115054, Russian Federation

${ }^{2}$ Moscow technology university "MIREA", Moscow, 119435, Russian Federation

${ }^{3}$ M.V. Keldish Institute of Applied Mathematics Russian Academy of Sciences, Moscow, 125047, Russian Federation

Authors' Information

Kim M.L., Chief technologist, e-mail: kimml@suek.ru

Rodichev A.S., Head of department, e-mail: rodichevas@suek.ru

Pevzner L.D., Doctor of Engineering Sciences, Professor, full member of the

Academy of Mining Sciences, e-mail: Ipevzner@msmu.ru

Platonov A.K., Doctor of Engineering Sciences, Professor

\section{Abstract}

The article describes mobile robotic aircraft application for hazardous mine area atmosphere damages detection and composition analysis. Parameters of drones, capable of operating in mine conditions. are given. Figures:

Fig. 1. Mine workings diagram and rescue brigade path (red line)

Fig. 2. Tentative aircraft design

\section{Keywords}

Mine, Robot, Lifesaver, Quadrocopter, Accident liquidation plan.

\section{References}

1. Ushakov K.Z., Kaledina N.O., Kirin B.F. et al. Bezopasnost vedeniya gornyh rabot i gornospasatelnoe delo [Mining safety and mining rescue activities]. Moscow, Moscow State Mining University Publ., 2008, 487 p.

2. Konurin A.I., Denisova E.V. \& Khmelinin A.P. Osnovnye problemy i perspektivy primeneniya bespilotnyh letatelnyh apparatov dlya obsledovaniya vyrabotannogo prostranstva pri podzemnoy razrabotke mestorozhdeniy [Main issues and outlook of air drones application for underground workings survey]. Fundamentalnye i prikladnye voprosy gorny hauk - Fundamental and application mining science issues, 2016, Vol. 1, No. 3, pp. 93-97.

3. Bondarev A.N. \& Kirichek R.V. Obzor bespilotnyh letatelnyh apparatov obshchego polzovaniya i regulirovaniya vozdushnogo dvizheniya BPLA $v$ raznyh stranah [General purpose air drones overview and air drones traffic regulation in different countries]. Informatsionnye tekhnologii i telekommunikatsii - Information Technologies and Telecommunications, 2016, Vol. 4, No. 4, pp. 13-23.

4. Rubin D.T., Konev V.N., Starikovsky A.V. \& Sheptunov A.A. Razrabotka kvadrokopterov so spetsialnymi svoystvami dlya provedeniya razvedyvatelnyh operatsiy [Development of special quadrocopters for survey works]. Spetstekhnika isvyaz - Special machinery and communications, 2012, No. 1.

5. Popov N.I., Yemelyanova O.V. \& Yatsun S.F. Modelirovanie dinamiki poleta kvadrokoptera [Quadrocopter flight dynamics simulation]. Vestnik Voronezhskogo instituta GPS MChS Rossii - Newsletter of the Voronezh State Fire Fighting Institute at EMERCOM of Russia, 2014.

6. Bui Van Sean, Bushuev A.B., Shmigelsky G.M. et al. Algoritmy upravleniya letayushchim robotom pri slezhenii za podvizhnym obektom [Aircraft drone control algorithm during mobile object tracing]. Izvestiya vysshikh uchebnykh zavedeniy. Priborostroenie - High Educational Institutions Newsletter. Instrument Engineering, 2015.

\section{СУЭК - в лидерах индексов устойчивого развития РСПП}

15 декабря 2017 г. Российский союз промышленников и предпринимателей (РСПП) опубликовал результаты четвертого выпуска индексов устойчивого развития, корпоративной ответственности и отчетности. СУЭК традиционно вошла в число лидеров индексов.

В индексе «Ответственность и открытость» СУЭК вошла в группу А (первая десятка, распределение в группе по алфавитному признаку), наряду с компаниями Лукойл, Роснефть, Норильский никель, Русал, Северсталь и др. Компания также находится на верхних позициях индекса «Вектор устойчивого развития».

По результатам индексов выявлена группа российских компаний-лидеров (указываются в алфавитном порядке без указания мест), в которую уверенно входит СУЭК.

«Соответствовать лучшим российским и мировым стандартам в области устойчивого развития, претворять в жизнь действительно нужные и важные проекты для страны, для общества, для жителей наших регионов эта задача поставлена перед компанией ее основным акционером Андреем Мельниченко. СУЭК сегодня по многим позициям находится в авангарде корпоративной соци-

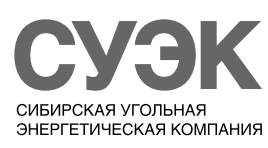

альной ответственности, опыт многих наших программ и проектов используется другими компаниями в другихрегионах. Мы этому только рады-значит, мы вместе - и государство, и общество, и бизнес, продуктивно работаем сообща, чтобы сделать жизнь жителей России лучше», - говорит заместитель генерального директора $\mathrm{AO}$ «СУЭК» Сергей Григорьев.

Индексы в области устойчивого развития, корпоративной ответственности и отчетности выпускаются РСПП с 2014 г. в рамках проекта по оценке ответственности и информационной открытости крупных российских компаний. В основе индексов лежит анализ публичной отчетности компаний. Индекс «Ответственность и открытость» отражает ситуацию в сфере раскрытия корпоративной информации по вопросам устойчивого развития и корпоративной ответственности. «Вектор устойчивого развития» - это индекс динамики результативности деятельности компаний в этой сфере, который оценивает направленность изменений основных социально-экономических и экологических показателей за ряд лет. СУЭК традиционно занимает лидирующие позиции в обоих индексах. 


\section{СУЭК и АМЗ «ВЕНТПРОМ» обсУдили аэрологическую безопасность угольных шахт}

28 ноября 2017 г. на Артемовском машинострочтельном заводе «Вентпром» состоялась научнопрактическая конференция «Аэрологическая безопасность угольных uaxm».

В конференции приняли участие начальник управления аэрологической безопасности АО «СУЭК» Олег Смирнов, возглавивший делегацию СУЭК, первый заместитель генерального директора АО АМЗ «Вентпром» Павел Вяткин, профессор Института горного дела им. Н.А. Чинакала Сибирского отделения РАН Александр Карасюк, проректор по учебно-методическому комплексу Уральского государственного горного университета Сергей Упоров, заведующий сектором Горного института Уральского отделения РАН Артем Зайцев и другие.

Аэрологическая безопасность рассматривалась на конференции как многофакторное понятие, включающее в себя нормативный газовый состав атмосферы шахты, метановую безопасность, пожарную безопасность, пылевую безопасность и безопасность при проведении аварийноспасательных работ.

«Роль аэрологчческой безопасности в производствегорныхработ чрезвычайно высока. Все последние значительные аварии, которые в России происходили, происходили именно по причине некачественного газоуправления и слабыхвентиляционных схем, - подчеркнул актуальность темы Олег Смирнов, - и мы сегодня здесь в том числе и для того, чтобы транслировать нашему партнеру серьезные задачи, поскольку очень заинтересованы в совместном развитии и безопасности наших людей».

На основе предложений, озвученных в докладе главного конструктора АM3 «Вентпром» Дениса Кутаева, а также предложений представителей $\mathrm{AO}$ «СУЭККузбасс» и AO «Уралуголь» определены параметры изменения и конструктивные улучшения вентиляторных установок с целью совершенствования систем газоудаления в шахтах.

В частности, были отмечены как заслуживающие внимания, требующие специальных исследований и внедрения предложения по увеличению параметров давления газоотсасывающих вентиляторов, а также возможности более глубокого регулирования вентиляторов местного проветривания.

Еще одной темой конференции, на которую обратил внимание проректор УГГУ Сергей Упоров, были оторванность выс-
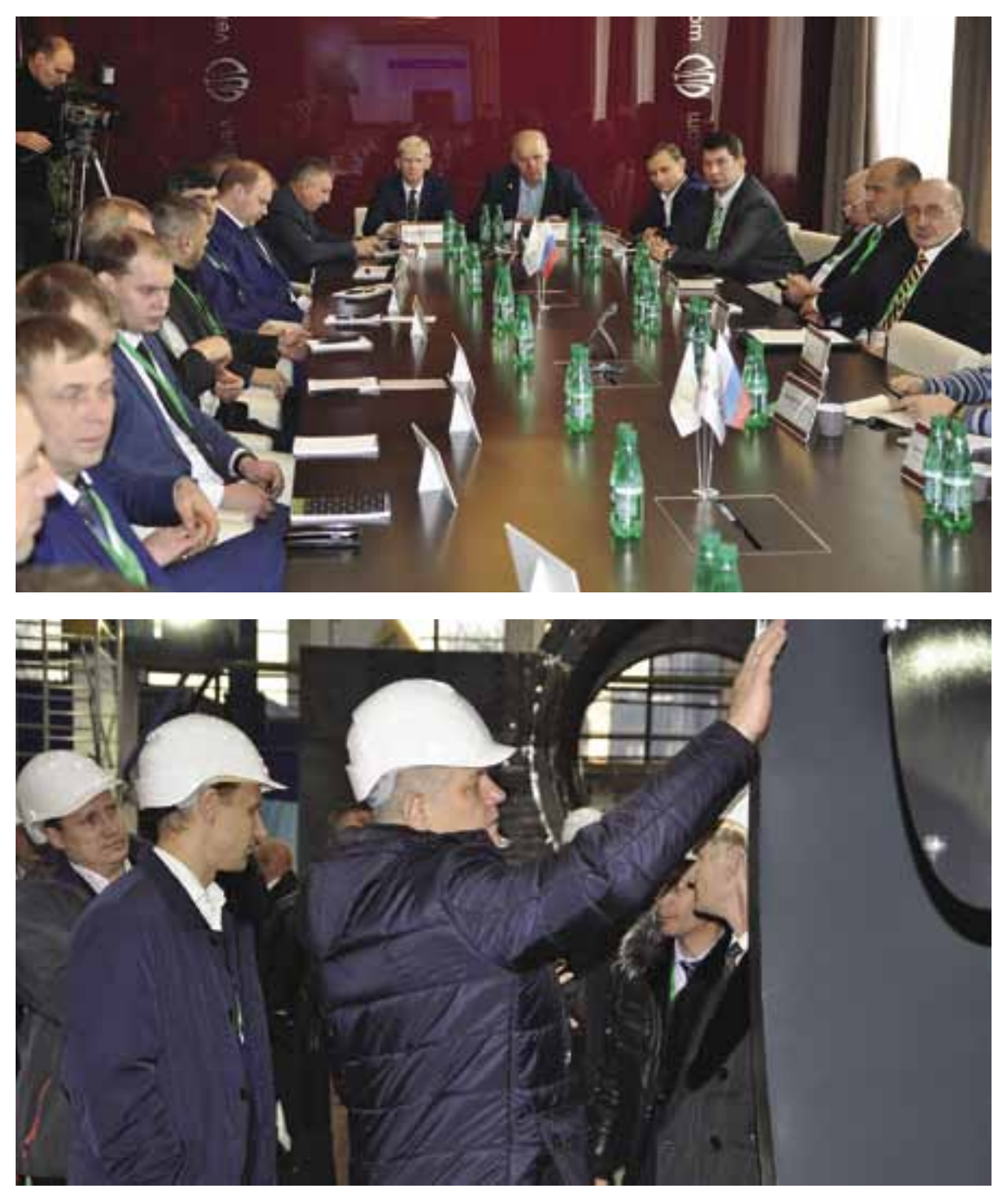

шей школы от реального производства и необходимость воспитания квалифицированных специалистов через укрепление связи с этими институтами.

Участникам конференции была также продемонстрирована новейшая разработка - первый отечественный осевой вентилятор главного проветривания подземных сооружений с поворотными на ходу лопатками рабочих колес «VР».

«Для нас чрезвычайно важно то, что мы услышали от производственников, от потребителей, поскольку совершенствовать продукцию без учета их мнения невозможно», - завершил работу конференции Павел Вяткин.

Наша справка.

АО «СУЭК»-одна из ведущихугледобывающих компаний мира, крупнейщий в России производитель угля, крупнейший поставщик на внутренний рынок и на экспорт. Компания объединяет 15 шахт, 12 разрезов, 9 обогатительных фабрик у установок, три порта, предприятия транспорта и ремонтно-механическиезаводы в восьми регионах России. На предприятиях СУЭК работают более 33500 человек. Основной акционер - Андрей Мельниченко. 


\section{Прогноз радоновой опасности \\ и расчет количества воздуха \\ для проветривания очистных участков \\ по радоновому фактору}

DOI: http://dx.doi.org/10.18796/0041-5790-2018-1-40-43

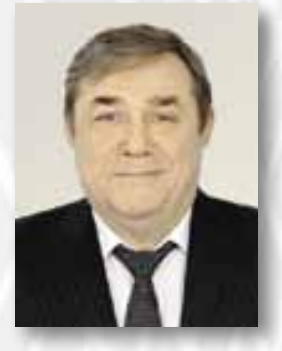

КАЧУРИН Николай Михайлович

Доктор техн. наук, профессор,

заведующий кафедрой

Тульского государственного

университета,

300012, г. Тула, Россия,

e-mail: ecology@tsu.tula.ru

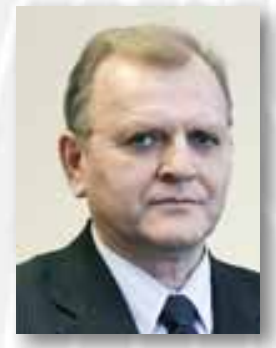

ЕФИМОВ Виктор Иванович

Доктор техн. наук,

заместитель директора

по перспективному развитию

Филиала АО ХК «СДС-Уголь» вг. Москве, профессор НИТУ «МИСИС»,

119034, г. Москва, Россия,

e-mail:v.efimov@sds-ugol.ru

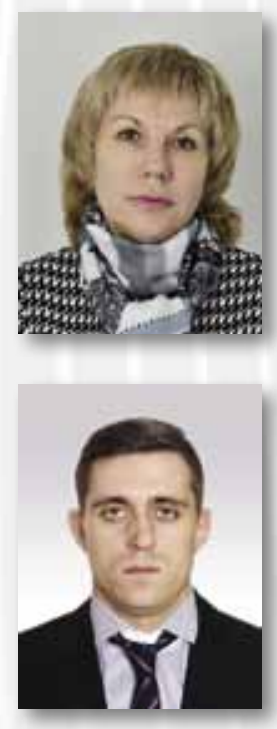

СТАСЬ Галина Викторовна

Канд. техн. наук, дочент

Тульского государственного

университета,

300012, г. Тула, Россия,

e-mail:galina_stas@mail.ru

\section{КАЧУРИН Александр Николаевич}

Канд. техн. наук,

инженер Тульского государственного

университета,

300012, г. Тула, Россия,

e-mail:ecology@tsu.tula.ru

Обоснованы закономерности переноса радона вентиляционной струей в выработках очистного участка. Показано, что целесообразно рассматривать одномерную конвективную диффузию. Доказано, что диффузионный перенос радона воздухом в выработках очистного участка происходит в стационарном режиме. Вычислительные эксперименты, выполненные для среднестатистических значений горно-геологических условий и технологических па- раметров, показали, что, как правило, фактор радоновыделения является превалирующим фактором на углекислотообильных шахтах при стабильном атмосферном давлении. При этом количество воздуха по фактору радоновыделения на 20-30\% превышает количество воздуха, необходимое для разбавления углекислого газа до предельно допустимого значения.

Ключевые слова: радон, воздух, конвективная диффузия, количество воздуха, очистной участок, объемная активность воздуха, математическая модель.

\section{ВВЕДЕНИЕ}

Исследования причин изменения состава рудничной атмосферы, газоносности углей, горных пород и их коллекторских свойств, генезиса газов угольных месторождений, источников газовыделения и их дебита, выполненные в России и за рубежом, показывают, что газовый фактор является одним из важнейших показателей общей безопасности подземных горных работ [1, 2, 3], и этот показатель должен отражать специфические особенности угольных бассейнов $[4,5,6]$. До некоторого времени в научных публикациях и действующем Руководстве по проектированию вентиляции угольных шахт для Подмосковного угольного бассейна газовые ситуации определялись двумя взаимосвязанными и одновременно протекающими процессами - выделением углекислого газа и поглощением кислорода из шахтного воздуха [7, 8, 9]. Однако исследования последних лет показали, что в структуре газового баланса шахт необходимо учитывать радон $[10,11]$.

\section{ПРОГНОЗ РАДОНОВОЙ ОПАСНОСТИ}

Согласно оценкам экспертов ООН, радон, вместе со своими дочерними продуктами распада, дает около 50\% эквивалентной дозы облучения. Для радона доказана корреляция между его содержанием в воздухе и заболеванием раком органов дыхания. Впервые такая связь была установлена для горняков урановых шахт Рудных гор в Германии, затем у горняков рудника на территории Ньюфаундленда и рудников Канады $[12,13,14]$.

Вновь обсуждаются перспективы возрождения Подмосковного угольного бассейна, в том числе и возможность строительства угольных шахт [15, 16, 17]. Поэтому имеющиеся методики расчета количества воздуха для проветривания очистных и подготовительных участков шахт Подмосковного бассейна необходимо уточнить по радоновому фактору. Диффузионный перенос радона 
воздухом в выработках очистного участка происходит в стационарном режиме. Учитывая соотношения поперечных размеров и суммарной длины выработок, целесообразно рассматривать одномерную конвективную диффузию [1, 2, 3].

\section{РАСЧЕТ КОЛИЧЕСТВА ВОЗДУХА \\ ДЛЯ ПРОВЕТРИВАНИЯ ОЧИСТНЫХ УЧАСТКОВ ПО РАДОНОВОМУ ФАКТОРУ}

Расчетная схема переноса радона в выработках очистного участка представлена на рис. 1 .

В выработках очистного участка средняя скорость движения воздуха достаточно велика, чтобы можно было пренебречь турбулентной диффузией, поэтому в общем виде нестационарная конвективная диффузия радона в выработках очистного участка описывается уравнением: $\partial A_{R n} / \partial t+u_{\text {o.y }} \partial A_{R n} / \partial x=-\lambda_{R n} A_{R n}+\Sigma I_{\text {о.у }}$, где: $A_{R n}$ - объемная активность воздуха по радону; $u_{\text {о.у }}$ средняя скорость воздуха в выработках очистного участка; $\Sigma I_{\text {о. }}$ - суммарные выделения радона в воздух в выработках очистного участка из различных источников; $\lambda_{R n}$ - константа скорости естественного радиоактивного распада радона; $t, x$ - время и пространственная координата соответственно. Натурные наблюдения и результаты вычислительных экспериментов показывают, что наиболее опасные распределения газовых примесей в воздухе формируются в виде стационарных продольных профилей концентраций рассматриваемых примесей.

Адаптируя это уравнение к реальным физическим условиям, перенос радона в выработках очистного участка можно описать следующим уравнением стационарной конвективной диффузии: $u_{\text {o.y }} \partial A_{R n} / \partial x=-\lambda_{R n} A_{R n}+\Sigma I_{\text {o.y. }}$. Решение этого уравнения для граничного условия $A_{R n}(0)=0$ имеет следующий вид:

$$
A_{R n}(x)=\frac{\Sigma I_{\text {o.y }}}{\lambda_{R n}}\left[1-\exp \left(-\frac{\lambda_{R n}}{u_{\text {o.y }}} x\right)\right] .
$$

Результаты вычислительных экспериментов представленынарис. 2 в видеграфиков зависимости $A_{R n}=A_{R n}(x) / A_{\infty}$ от координаты $x$, где $A_{\infty}=\Sigma I_{\text {о.y }} / \lambda_{R n}$. Вычислительные эксперименты проведены для различных значений $\omega$, где $\omega=\lambda_{R n} / u_{\text {o.y }}$.

Анализ результатов вычислительных экспериментов показывает, что при больших значениях $x$ удельная активность воздуха по радону стремиться к асимптотическому значению $A_{\infty}$. Удельная активность воздуха в выработках очистного участка зависит от величины абсолютного радоновыделения, скорости радиоактивного распада радона и средней скорости движения воздуха. Следовательно, зависимость (1) может использоваться для прогнозной оценки радоновой опасности в выработках очистного участка. Связь удельной активности воздуха со средней скоростью его движения позволяет рас- считать количество воздуха очистного участка по фактору радоновыделения динамическим методом (то есть сучетом конвективного переноса). При этом средняя по сечению выработки концентрация радона не должна превышать ПДА ${ }_{R n^{\prime}}$ где:ПДА ${ }_{R n}$ - предельно допустимая активность воздуха по радону. Решая уравнение (1) для $A_{R n}(x)=\Pi Д \mathrm{~A}_{R n}$ при $x=(S L)$ o.у, где $(S L)$ o.у - суммарная длина выработок очистного участка, относительно средней скорости движения воздуха, и переходя к объемному расходу воздуха получим, следующую формулу для расчета количества воздуха по фактору радоновыделения:

$$
Q_{R n}^{\text {оч }}=\frac{\lambda_{R n}(\Sigma L)_{\text {o.y }} S_{\text {э }}}{\ln \left|\Sigma I_{\text {o.y }}\left(\Sigma I_{\text {o.y }}-\lambda_{R n} \Pi Д \mathrm{~A}_{R n}\right)^{-1}\right|},
$$

где: $Q_{R n}^{\text {оч }}$ - количество воздуха, которое необходимо подавать на очистной участок, чтобы объемная активность воздуха по радону на исходящей струе не превышала величины ПДА ${ }_{R n} ;(S L)_{\text {о.у }}$ - суммарная проектная длина вые-

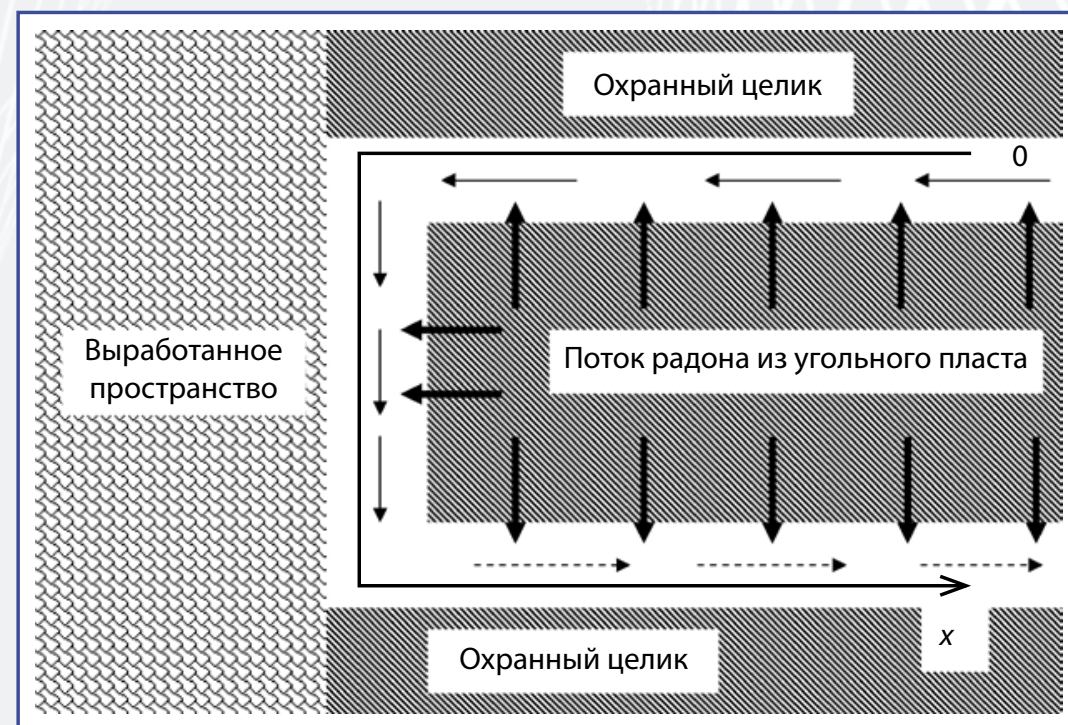

Puc. 1. Расчетная схема переноса радона в выработках очистного участка

Fig. 1. Calculation model for radon transfer in production face working areas

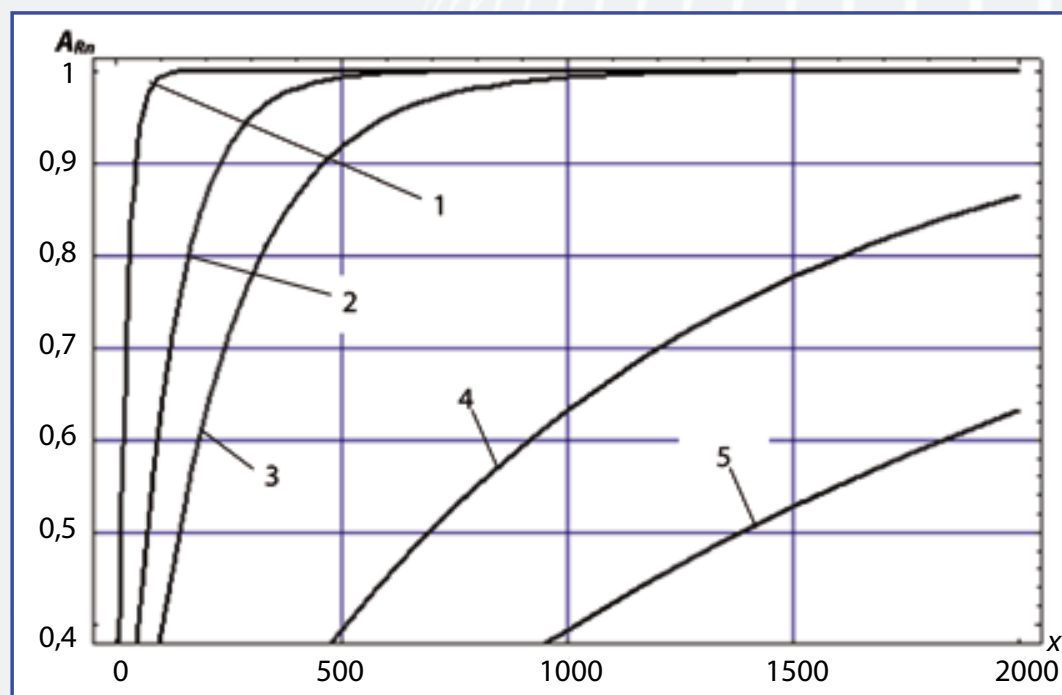

Puс. 2. Графики зависимости $\boldsymbol{A}_{R n}$ от координаты х для выработок очистного участка. Значения $W_{1} 1 / \mathrm{M}_{\mathrm{Rn}} 1-5 \times 10^{-2} ; 2-10^{-2} ; 3-5 \times 10^{-3} ; 4-10^{-3} ; 5-5 \times 10^{-4}$

Fig. 2. Charts of $\boldsymbol{A}_{R n}$ dependence on $x$ for production face working area. Values $\omega$, $1 / \mathrm{m}: 1-5 \times 10^{-2} ; 2-10^{-2} ; 3-5 \times 10^{-3} ; 4-10^{-3} ; 5-5 \times 10^{-4}$ 
Расчет количества воздуха для очистных участков шахт Подмосковного бассейна

\begin{tabular}{|c|c|c|c|c|}
\hline \multirow[b]{2}{*}{$\begin{array}{c}\text { Сочетание } \\
\text { расчетных } \\
\text { параметров }\end{array}$} & \multicolumn{2}{|c|}{ Расчетная углекислотообильность, м³/мин. } & \multicolumn{2}{|c|}{ Расчетное количество воздуха, м³/мин. } \\
\hline & $\begin{array}{c}\text { Среднестатистический } \\
\text { очистной участок }\end{array}$ & $\begin{array}{c}\text { Очистной участок } \\
\text { с оптимальными } \\
\text { параметрами }\end{array}$ & $\begin{array}{c}\text { По фактору } \\
\text { выделения } \\
\text { углекислого газа }\end{array}$ & $\begin{array}{c}\text { По фактору } \\
\text { радоновыделения }\end{array}$ \\
\hline Максимальное & 0,85 & 1 & $201-260$ & 274 \\
\hline Минимальное & 0,1 & 0,24 & $36-86$ & 156 \\
\hline Среднее & 0,63 & 0,74 & $189-222$ & 231 \\
\hline
\end{tabular}

мочных штреков и лавы; $S_{\text {э }}$ - эквивалентная по расходу воздуха площадь поперечного сечения выработок очистного участка.

Результаты расчета количества воздуха для очистных участков действовавших шахт Подмосковного бассейна представлены в таблице.

\section{ЗАКЛЮЧЕНИЕ}

Вычислительные эксперименты, выполненные для среднестатистических значений горно-геологических условий и технологических параметров, показали, что, как правило, фактор радоновыделения является превалирующим фактором на углекислотообильных шахтах при стабильном атмосферном давлении. При этом количество воздуха по фактору радоновыделения на 20-30\% превышает количество воздуха, необходимое для разбавления углекислого газа до предельно допустимого значения.

\section{Список литературы}

1. Экологические последствия закрытия угольных шахт Кузбасса по газодинамическому фактору и опасности эндогенных пожаров на отвалах / Н.М. Качурин, С.А. Воробьев, Я.В. Чистяков, Л.Л. Рыбак // Экология и промышленность России. 2015. № 4. С. 54-58.

2. Качурин Н.М., Ефимов В.И., Воробьев С.А. Методика прогнозирования экологических последствий подземной добычи угля в России // Горный журнал. 2014. № 9. C. 138-142.

3. Kachurin N.M., Efimov V.I., Vorobev S.A., Shkuratckiy D.N. Evaluating of closed mines mining lease territories environmental safety by gas factor // Eurasian Mining. 2014. № 2. Pp. 41-44.

4. Kachurin N.M., Vorobev S.A., Korchagina T.V., Sidorov R.V. Scientific and practical results of monitoring of anthropogenic influence on mining-industrial territories environment // Eurasian Mining. 2014. No 2. Pp. 44-48.

5. Nikolai Kachurin, Vitaly Komashchenko, Vladimir Morkun. Environmental monitoring atmosphere of mining territories // Metallurgical and Mining Industry. 2015. No 6. Pp. 595-598.

6. Kachurin N.M., Vorobev S.A., Vasilev P.V. Generalized mathematical model for gases filtration in coal beds and enclosing strata // Eurasian Mining. 2015. No 2.

7. Kachurin N.M., Vorobev S.A., Vasilev P.V. Methane emission from coal bed open surfaces into development workings and production faces by intensive gas-bearing coal extraction // Eurasian Mining. 2015. No 2.

8. Аппроксимация аэродинамических характеристик проходческих вентиляторов для автоматизации вентиляционных расчетов / Н.М. Качурин, С.А. Воробьев, А.Д. Левин, П.В. Васильев // Горный журнал. 2015. № 12. С. 76-79.
9. Перспективы восстановления и комплексного развития Подмосковного буроугольного бассейна / Н.М. Качурин, С.А. Воробьев, П.В. Васильев, С.М. Богданов // Горный журнал. 2016. № 2. С. 30-35.

10. Границы применимости линеаризованных уравнений фильтрации газов и прогноз динамики газовыделения из выработанного пространства / Н.М. Качурин, С.А. Воробьев, О.А. Афанасьев, Д.Н. Шкуратский // Известия Тульского государственного университета. Технические науки. 2014. Вып. 1. С. 152-158.

11. Экологически безопасная геотехнология комплексного освоения месторождений бурого угля / Н.М. Качурин, В.И. Ефимов, В.В. Факторович, Е.К. Мосина // Безопасность труда в промышленности. 2014. № 10. С. 65-70.

12. Распределение ресурсов на профилактику загрязнения атмосферы горнопромышленного района / Н.М. Качурин, Л.Л. Рыбак, В.И. Ефимов, С.А. Воробьев // Безопасность труда в промышленности. 2015. № 2. С. 24-27.

13. Оценка предельно допустимых пылегазовых выбросов горных предприятий в атмосферу / Н.М. Качурин, Л.Л. Рыбак, В.И. Ефимов, С.А. Воробьев // Безопасность труда в промышленности. 2015. № 3. С. 36-39.

14. Аэродинамика породных отвалов угольных шахт / Н.М. Качурин, Г.В. Стась, А.Д. Левин, В.Л. Рыбак // Известия Тульского государственного университета. Науки о Земле. 2016. Вып. 1. С. 23-34.

15. Моделирование режимов работы систем вентиляции подготовительных выработок / Н.М. Качурин, С.А. Воробьев, А.Д. Левин, П.В. Васильев // Известия Тульского государственного университета. Науки о Земле. 2016. Вып. 1. С. $156-167$.

16. Kachurin N.M., Vorobev S.A., Bogdanov S.M. Evaluating Polluting Atmosphere be Mining Enterprises and Optimizing Prophylactic Measures Resources / 5th International Symposium. Mining and Environmental Protection. Vrdnik. Serbia. 2015. Pp. 135-140.

17. Environmental Danger of Worked and Liquidated Coal Mines Open Areas / N.M. Kachurin, S.A. Vorobev, D.N. Shkuratckiy, S.M. Bogdanov / 5th International Symposium. Mining and Environmental Protection. Vrdnik. Serbia. 2015. Pp. 141-149.

18. Качурин Н.М., Поздеев А.А., Стась Г.В. Прогноз выделения радона в горные выработки угольных шахт // Известия Тульского государственного университета. Естественные науки. 2012. Вып. 1. Ч. 2. С. 133-142.

19. Качурин Н.М., Поздеев А.А., Стась Г.В. Выделения радона в атмосферу горных выработок угольных шахт // Известия Тульского государственного университета. Науки о Земле. 2012. Вып. 1. С. 46-56.

20. Радон в атмосфере угольных шахт / Н.М. Качурин, А.А. Поздеев, Н.И. Абрамкин, Г.В. Стась // Горный информационно-аналитический бюллетень. 2012. №8. С. 88-94. 
UDC 622.411.39:546.296 @ N.M. Kachurin, V.I. Efimov, G.V. Stas, A.N. Kachurin, 2018

ISSN 0041-5790 (Print) • ISSN 2412-8333 (Online) • Ugol' - Russian Coal Journal, 2018, № 1, pp. 40-43

Title

FORECASTING RADON DANGER AND CALCULATING QUANTITY OF AIR FOR VENTILATION OF PRODUCTION FACES BY RADON FACTOR

DOI: http://dx.doi.org/10.18796/0041-5790-2018-1-40-43

\section{Authors}

Kachurin N.M. ${ }^{1}$, Efimov V.I. ${ }^{2,3}$, Stas G.V. ${ }^{1}$, Kachurin A.N

${ }^{1}$ Tula State University, Tula, 300012, Russian Federation

${ }^{2}$ National University of Science and Technology "MISIS" (NUST "MISIS"), Moscow, 119049, Russian Federation

3 "SBU-Coal" Holding Company, JSC, Moscow Branch, Moscow, 119034, Russian Federation

\section{Authors' Information}

Kachurin N.M., Doctor of Engineering Sciences, Professor, Head of a Chair, e-mail: ecology@tsu.tula.ru

Efimov V.I., Doctor of Engineering Sciences, Professor, Deputy Director for Future Development, e-mail: v.efimov@sds-ugol.ru

Stas G.V., PhD (Engineering), Associate Professor, e-mail: galina_stas@mail.ru Kachurin A.N., PhD (Engineering), Engineer, e-mail: ecology@tsu.tula.ru

\section{Abstract}

Regularities of radon transfer by ventilation jet in mining workings of production face were substantiated. It's shown that reasonably considering one-dimension convective diffusion. Diffusion radon transfer by air in mining workings of production face realizes at stationary regime. Results of calculated experiments which realized for typical values of geological-mining conditions and technological parameters demonstrated that as a rule the factor of radon emitting is dominant factor for carbon dioxide danger mines by stable atmospheric pressure. Quantity of air by that factor better on $20-30 \%$ then quantity of air which necessity for diluting carbon acid until maximum allowable concentration.

Figures:

Fig. 1. Calculation model for radon transfer in production face working areas Fig. 2. Charts of $\boldsymbol{A}_{R n}$ dependence on $x$ for production face working area. Values $\omega, 1 / \mathrm{m}$ :

$1-5 \times 10^{-2} ; 2-10^{-2} ; 3-5 \times 10^{-3} ; 4-10^{-3} ; 5-5 \times 10^{-4}$

\section{Keywords}

Radon, Air, Convective diffusion, Quantity of air, Production face, Volumetric activity of air, Mathematical model.

\section{References}

1. Kachurin N.M., Vorobyev S.A., Chistyakov Ya.V. \& Rybak L.L. Ekologicheskie posledstviya zakrytiya ugolnyh shaht Kuzbassa po gazodinamicheskomu faktoru i opasnosti endogennyh pozharov na otvalah [Environmental consequences of Kuzbass coal mines shutdown by gas-dynamic factor and dumps endogenous fire hazard]. Ekologiya i promyshlennost Rossii - Environment and Industry of the Russia, 2015, No. 4, pp. 54-58.

2. Kachurin N.M., Efimov V.I. \& Vorobev S.A. Metodika prognozirovaniya ekologicheskih posledstviy podzemnoy dobychi uglya v Rossii [Methodology for underground coal mining environmental impact prediction in Russia] Gornyy Zhurnal - Mining Journal, 2014, No. 9, pp. 138-142.

3. Kachurin N.M., Efimov V.I., Vorobev S.A. \& Shkuratckiy D.N. Evaluating of closed mines mining lease territories environmental safety by gas factor Eurasian Mining, 2014, No. 2, pp. 41-44.

4. Kachurin N.M., Vorobev S.A., Korchagina T.V. \& Sidorov R.V. Scientific and practical results of monitoring of anthropogenic influence on mining industrial territories environment. Eurasian Mining, 2014, No. 2, pp. 44-48. 5. Nikolai Kachurin, Vitaly Komashchenko, Vladimir Morkun. Environmenta monitoring atmosphere of mining territories. Metallurgical and Mining In dustry, 2015, No. 6, pp. 595-598.

6. Kachurin N.M., Vorobev S.A. \& Vasilev P.V. Generalized mathematical model for gases filtration in coal beds and enclosing strata. Eurasian Mining, 2015, No. 2.

7. Kachurin N.M., Vorobev S.A. \& Vasilev P.V. Methane emission from coal bed open surfaces into development workings and production faces by intensive gas-bearing coal extraction. Eurasian Mining, 2015, No. 2.

8. Kachurin N.M., Vorobev S.A., Levin A.D. \& Vasilev P.V. Approksimatsiya aerodinamicheskih harakteristik prohodcheskih ventilyatorov dlya avtomatizatsii ventilyatsionnyh raschetov [Shaft fan aerodynamic characteristics approximation for ventilation calculations automation]. Gornyy Zhurnal Mining Journal, 2015, No. 12, pp. 76-79.

9. Kachurin N.M., Vorobev S.A., Vasilev P.V. \& Bogdanov S.M. Perspektivy vosstanovleniya i kompleksnogo razvitiya Podmoskovnogo burougolnogo basseyna [Prospects for restoration and integrated development of lignite basin near Moscow]. Gornyy Zhurnal - Mining Journal, 2016, No. 2, pp. 30-35. 10. Kachurin N.M., Vorobev S.A., Afanasyev O.A. \& Shkuratsky D.N. Granitsy primenimosti linearizovannyh uravneniy filtratsii gazov i prognoz dinamiki gazovydeleniya iz vyrabotannogo prostranstva [Limits of linearized gas filtration equations applicability and forecast of gas evolution dynamics from depleted space]. Izvestiya Tul'skogo gosudarstvennogo universiteta. Tekhnicheskie nauki - Tula State University Newsletter. Technical sciences, 2014, issue 1, pp. 152-158.

11. Kachurin N.M., Efimov V.I., Faktorovich V.V., Mosina E.K. Ekologicheski bezopasnaya geotekhnologiya kompleksnogo osvoeniya mestorozhdeniy burogo uglya [Environmentally safe geotechnology of lignite field development]. Bezopasnost truda v promyshlennosti - Industrial Labor Safety, 2014, No. 10 , pp. $65-70$.

12. Kachurin N.M., Rybak L.L., Efimov V.I., Vorobev S.A. Raspredelenie resursov na profilaktiku zagryazneniya atmosfery gornopromyshlennogo rayona [Resources distribution for mining area atmosphere pollution prevention]. Bezopasnost truda v promyshlennosti - Industrial Labor Safety, 2015, No. 2, pp. 24-27.

13. Kachurin N.M., Rybak L.L., Efimov V.I. \& Vorobev S.A. Otsenka predelno dopustimyh pylegazovyh vybrosov gornyh predpriyatiy $v$ atmosferu [Estimation of max allowable mining enterprises dust and gas atmospheric emissions]. Bezopasnost truda v promyshlennosti - Industrial Labor Safety, 2015, No. 3, pp. 36-39.

14. Kachurin N.M., Stas G.V., Levin A.D. \& Rybak V.L. Aerodinamika porodnyh otvalov ugolnyh shaht [Coal mines dumps aerodynamics]. Izvestiya Tul'skogo gosudarstvennogo universiteta. Nauki o Zemle - Tula State University Newsletter. Earth Sciences, 2016, issue 1, pp. 23-34.

15. Kachurin N.M., Vorobev S.A., Levin A.D., Vasilev P.V. Modelirovanie rezhimov raboty sistem ventilyatsii podgotovitelnyh vyrabotok [Development galleries ventilation systems operating modes simulation]. Izvestiya Tul'skogo gosudarstvennogo universiteta. Nauki o Zemle - Tula State University Newsletter. Earth Sciences, 2016, issue 1, pp. 156-167.

16. Kachurin N.M., Vorobev S.A. \& Bogdanov S.M. Evaluating Polluting Atmosphere be Mining Enterprises and Optimizing Prophylactic Measures Resources. 5th International Symposium. Mining and Environmental Protection. Vrdnik, Serbia, 2015, pp. 135-140.

17. Kachurin N.M., Vorobev S.A., Shkuratckiy D.N. \& Bogdanov S.M. Environmental Danger of Worked and Liquidated Coal Mines Open Areas. 5th International Symposium. Mining and Environmental Protection. Vrdnik, Serbia, 2015, pp. 141-149.

18. Kachurin N.M., Pozdeyev A.A. \& Stas G.V. Prognoz vydeleniya radona v gornye vyrabotki ugol'nyh shaht [Forecast of radon emission to coal mines workings]. Izvestiya Tul'skogo gosudarstvennogo universiteta. Estestvennye nauki - News of the Tula State University. Natural Sciences, 2012, Vol. 1, Pt. 2, pp. 133-142

19. Kachurin N.M., Pozdeyev A.A. \& Stas G.V.Vydeleniya radona $v$ atmosferu gornyh vyrabotok ugolnyh shaht [Radon emission to coal mines workings atmosphere]. Izvestiya Tul'skogo gosudarstvennogo universiteta. Naukio Zemle - Tula State University Newsletter. Earth Sciences, 2012. issue 1, pp. 46-56. 20. Kachurin N.M., Pozdeyev A.A., Abramkin N.I. \& Stas G.V. Radon v atmosfere ugolnyh shaht [Radon in coal mines atmosphere]. Gornyy InformatsionnoAnaliticheskiy Byulleten' - Mining Information and Analytical Bulletin, 2012 No. 8, pp. 88-94. 


\section{Влияние параметров грубодисперсных пылегазовоздушных смесей на время их выгорания в горных выработках угольных шахт}

DOI: http://dx.doi.org/10.18796/0041-5790-2018-1-44-49

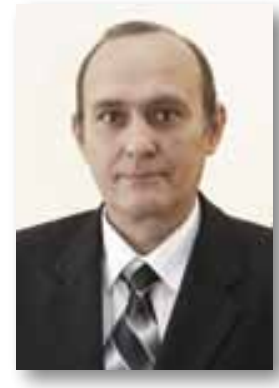

\section{ЧЕРДАНЦЕВ Сергей Васильевич}

Доктор техн. наук, ведущий научный сотрудник AO «НЦ ВостНИИ», 650002, г. Кемерово, Россия, тел.: +7 (913) 29-65-591, e-mail:svch01@yandex.ru

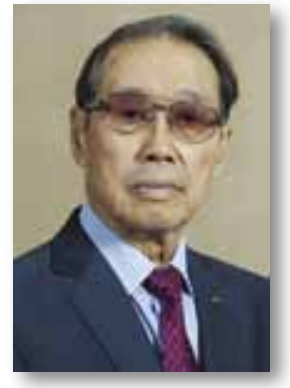

\section{ли Хи Ун}

Доктор техн. наук, профессор, заместитель генерального директора по научной работе $A O$ «HЦ ВостHИИ», 650002, г. Кемерово, Россия, тел.: +7 (3842) 64-28-95, e-mail: leeanatoly@mail.ru

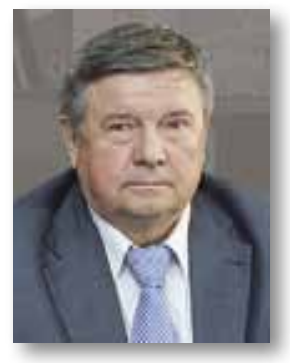

\section{ФИЛАТОВ Юрий Михайлович}

Канд. техн. наук, генеральный директор $A O$ «HЦ ВостHИИ», 650002, г. Кемерово, Россия, тел.: +7 (3842)64-30-99, e-mail:main@nc-vostnii.ru

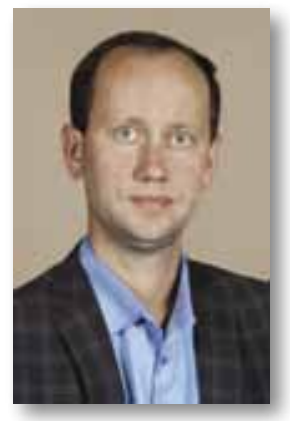

ШЛАПАКОВ Павел Александрович Заведующий лабораторией $A O$ «НЦ ВостHИИ», 650002, г. Кемерово, Россия, тел. +7 923-510-37-21, e-mail: shlapak1978@mail.ru
Рассмотрен процесс горения грубодисперсных пылегазовоздушных смесей, находящихся в атмосфере горныхвыработок. Горение смесей рассматривается как совокупность двух процессов: гетерогенного, протекающего на внешней поверхности угольных частиц, и гомогенного, протекающего внутри их объема. На базе уравнения, выражающего закон сохранения массы, получена формула, определяющая время выгорания грубодисперсных пылегазовоздушных смесей. Построены графики зависимостей времени выгорания смеси от параметров смесей. Установлено влияние различных параметров смесей на время их выгорания. Выполнен анализ числовых значений и функций, определяющих время выгорания грубодисперсных пылегазовоздушных смесей. Выявлены условия, при которых горение грубодисперсных пылегазовоздушных смесей происходит в различных режимах горения.

Ключевые слова: горные выработки, грубодисперсные пылегазовоздушные смеси, скорость химической реакции, уравнение Аррениуса, коэффициент диффузии, реакционная поверхность пор, суммарное сопротивление химической реакции.

\section{ВВЕДЕНИЕ}

Развитие угольной промышленности в последние годы характеризуется стабильным повышением техникоэкономических показателей, что обусловлено использованием современного горно-шахтного оборудования и совершенствованием технологии очистных и подготовительных работ.

Однако ряд факторов сдерживает увеличение добычи угля подземным способом, главным из которых является процесс самонагревания угля, представляющий собой сложный процесс, обусловленный химической кинетикой протекания реакций окисления углеродосодержащих веществ и тепломассопереносом как исходных смесей, так и продуктов химической реакции окисления. Очаги самонагревания, характеризуемые повышенной температурой, могут вызвать зажигание и горение пылегазовоздушных смесей (ПГВС) в горных выработках.

Процессы зажигания и горения достаточно хорошо изучены, а библиография по этой тематике весьма обширна. Достаточно указать на работы отечественных $[1,2,3,4,5$, 6, 7, 8, 9] и зарубежных [10, 11, 12, 13, 14, 15, 16] авторов. 
Однако подавляющее большинство работ посвящено горению и сжиганию углеродосодержащих веществ в специальных энергетических агрегатах на тепловых электрических станциях.

Целями данной работы являются определение времени выгорания грубодисперсных ПГВС в горных выработках и анализ влияния на время выгорания некоторых параметров ПГВС.

В работе приняты следующие допущения:

- грубодисперсная угольная частица имеет сферическую форму, текущий радиус которой $\xi$, а начальный радиус $r_{0}$ имеет размеры $10^{-4} \mathrm{M} \leq r_{0} \leq 5 \times 10^{-4} \mathrm{M}$;

- внутренняя пористая поверхность частицы, которую будем считать однородной и изотропной, характеризуется постоянным коэффициентом диффузии $D$ внутри частицы и реакционной поверхностью пор $\bar{S}_{i^{\prime}}$ отнесенной к единице объема частицы. Поэтому будем полагать, что перенос реагирующего вещества происходит только за счет молекулярной диффузии.

\section{ПОСТАНОВКА И РЕШЕНИЕ ЗАДАЧИ \\ О ВЫГОРАНИИ ГРУБОДИСПЕРСНОЙ \\ ПЫЛЕГАЗОВОЗДУШНОЙ СМЕСИ}

Допустим, что процесс горения протекает при концентрации реагирующего газа (кислорода) в горной выработке $c_{0}$. Уравнение выгорания сферической частицы, плотность которой $\gamma_{T}$, за время $d t$ представляется в достаточно простом виде [5, 9]:

$$
-\gamma_{\mathrm{T}} d \xi=q d t
$$

где: $t$ - время, $q$ - скорость протекания реакции горения. Для определения $q$ вначале найдем общую скорость $W$ реакции как сумму скоростей реакций, протекающих на внешней поверхности частицы и внутри ее:

$$
W=k S_{e} c_{w}+k S_{i} c_{i}=k S_{e} c_{w}+k \overline{S_{i}} V c_{i},
$$

где: $c_{w^{\prime}} c_{i}$ - концентрация реагирующего газа соответственно на внешней поверхности и внутри ее; $S_{e^{\prime}} S_{i}-$ внешняя и внутренняя поверхности частицы; $V$ - ее объем; $\bar{S}_{i}=S_{i} / V ; k$-константа скорости реакции, которую определим из уравнения Аррениуса:

$$
k=k_{0} e^{-E / R T} .
$$

В формуле (3): $k_{0}=3,5 \cdot 10^{3} c^{-1}-$ предэкспоненциальный множитель; $E=133 \cdot 10^{3}$ Дж/моль - энергия активации, которой должна обладать молекула, чтобы прореагировать; $R=8,314$ Дж/(моль К) - газовая постоянная.

Разделив равенство (2) на $S_{e}$ и полагая, что $c_{w} \approx c_{i^{\prime}}$ найдем удельную скорость реакции $q$, отнесенную к единице площади внешней поверхности частицы:

$$
q=k\left(1+\bar{S}_{i} \varepsilon\right) c_{w},
$$

где: величина $\varepsilon=V / S_{e}$ характеризует глубину проникновения реакции внутрь частицы. В частности, для частицы сферической формы $S_{e}=4 \pi \xi^{2}, V=4 \pi \xi^{3} / 3$ величина $\varepsilon=\xi / 3$. Подставим в (1) формулу (4), в которой величину $k c_{w}$ заменим на $\tilde{k} c_{0}$ :

$$
-\gamma_{\mathrm{T}} \frac{1}{\tilde{k}} d \xi=\left(1+\bar{S}_{i} \frac{\xi}{3}\right) c d t
$$

здесь величина 1 / $\tilde{k}$ - является химическим сопротивлением, определяемым как [5]:

$$
\frac{1}{\tilde{k}}=\frac{1}{k}+\frac{\xi}{D}+\frac{a \xi^{2}}{D},
$$

где: $a=\bar{S}_{i} / 3, D-$ коэффициент диффузии.

Подставляя (6) в равенство (5), получаем дифференциальное уравнение

$$
-\left(\frac{1}{k}+\frac{\xi}{D}+\frac{a \xi^{2}}{D}\right) \frac{d \xi}{\left(1+\bar{S}_{i} \xi / 3\right)}=\frac{c_{0}}{\gamma_{\mathrm{T}}} d t,
$$

переменные, в котором уже разделены. Поэтому, интегрируя и раскрывая скобки, приведем его к виду:

$$
-\frac{1}{k} \int_{r_{0}}^{0} \frac{d \xi}{1+a \xi}-\frac{1}{D} \int_{r_{0}}^{0} \frac{\xi d \xi}{1+a \xi}-\frac{a}{D} \int_{r_{0}}^{0} \frac{\xi^{2} d \xi}{1+a \xi}=\frac{c_{0}}{\gamma_{\mathrm{T}}} t_{\mathrm{r}},
$$

где $t$ - время выгорания угольной частицы.

Отыскав интегралы в уравнении (7), которые являются табличными, приведем его к виду

$$
\begin{aligned}
& \frac{1}{k a} \ln \left(1+a r_{0}\right)+\frac{1}{D a^{2}}\left[a r_{0}-\ln \left(1+a r_{0}\right)\right]+ \\
& +\frac{1}{D a^{2}}\left[a^{2} r_{0}^{2}-2 a r_{0}+2 \ln \left(1+a r_{0}\right)\right]=\frac{c_{0}}{\gamma_{\mathrm{T}}} t,
\end{aligned}
$$

откуда получаем формулу

$$
t_{\mathrm{r}}=\frac{3 \gamma_{\mathrm{T}}}{\bar{S}_{i} k c_{0}}\left[\ln \left(1+\frac{\bar{S}_{i} r_{0}}{3}\right)+\frac{\overline{S_{i}} r_{0}^{2} k}{6 D}\right],
$$

определяющую время выгорания грубодисперсной ПгВС.

\section{АНАЛИЗ ПОЛУЧЕННЫХ РЕЗУЛЬТАТОВ}

Далее исследуем влияние различных параметров угольных частиц на время их выгорания, для чего построим графики зависимостей времени выгорания угольных частиц $t_{\text {г }}$ от различных параметров, влияющих на процесс выгорания. 


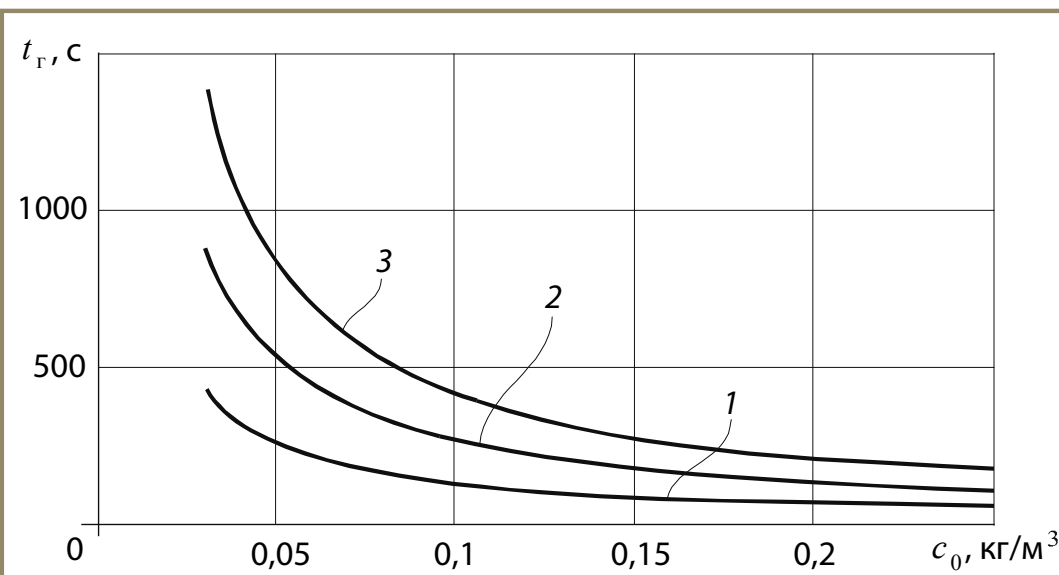

Pис. 2. Зависимость времени выгорания частиц $t_{\mathrm{r}}$ от начальной кониентрачии $c_{0}$

Fig. 2. Schedules of dependence of time of burning $t_{\mathrm{r}}$ out of particles of initial concentration $c_{0}$

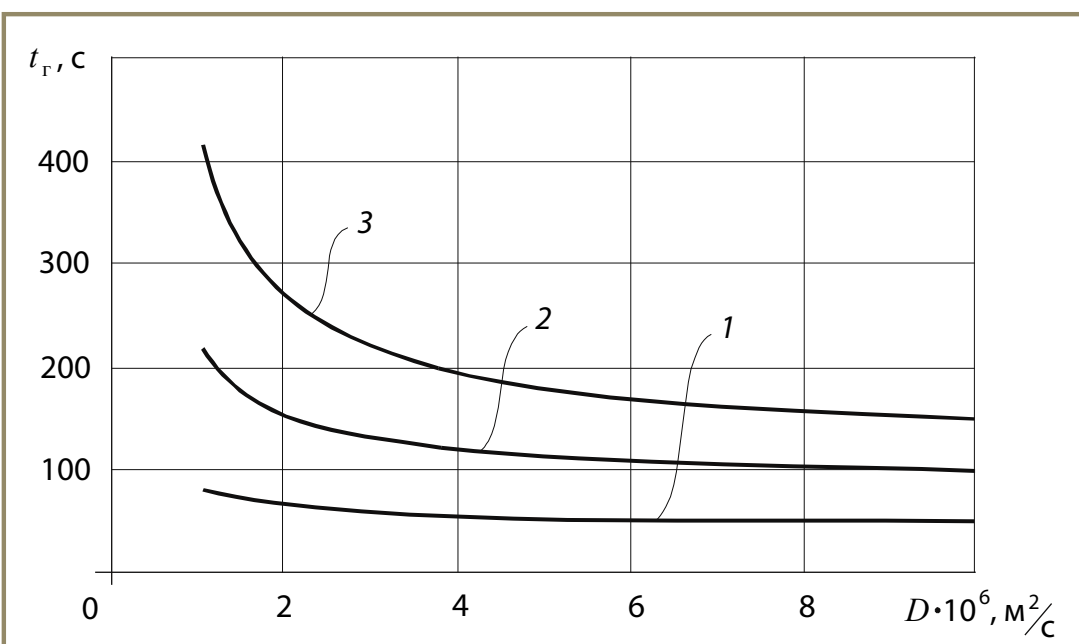

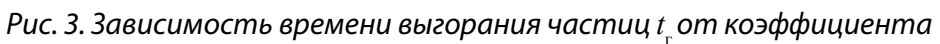
дифффузии $D \cdot 10^{6}$

Fig. 3. Schedules of dependence of time of burning $t_{\Gamma}$ out of particles from the diffusion coefficient $D \cdot 10^{6}$

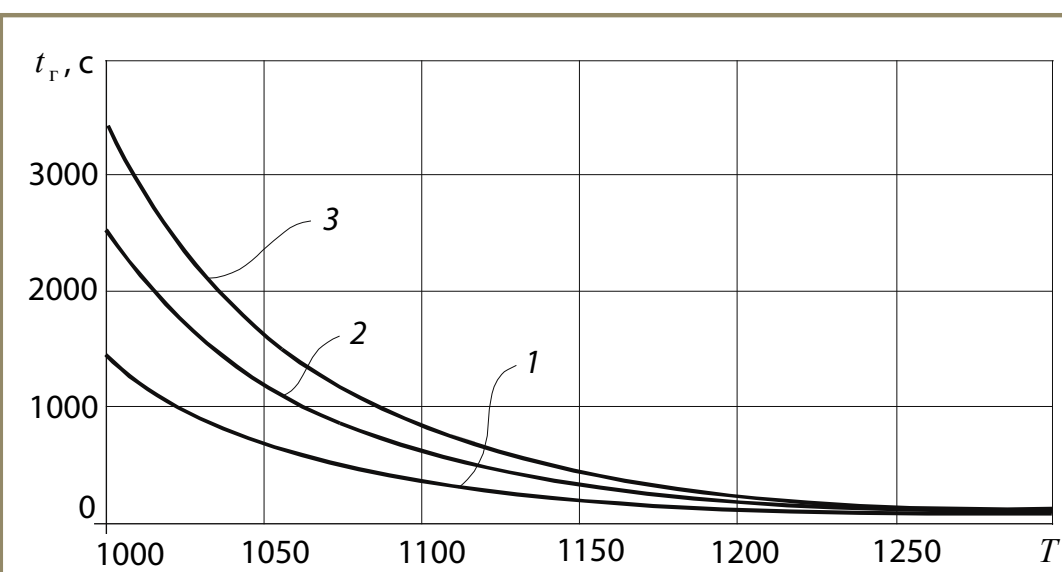

Pис. 4. Зависимость времени выгорания частиц $t_{\mathrm{r}}$ от температуры $T$

Fig. 4. Schedules of dependence of time $t_{\mathrm{r}}$ of the burning particle temperature $T$ размером $r_{0}=0,2$ мм, кривая $3-r_{0}=0,3$ мм.

Отметим, что кривая 1, соответствующая частице $r_{0}=0,1$ мм мало отличается от прямой линии, но с увеличением размера частицы графики имеют небольшую положительную кривизну, которая увеличивается по мере роста $r_{0}$ и уменьшения величины относительной внутренней поверхности $\overline{S_{i}}$.

Все три кривые показывают, что независимо от размера частиц с ростом величины внутренней поверхности время их выгорания уменьшается, хотя и не очень существенно, особенно для частиц малых размеров.

На рис. 2 представлены кривые зависимости времени выгорания частиц от величины начальной концентрации $c_{0}$, построенные при $\bar{S}_{i}=70 \mathrm{~cm}^{-1}, D=5 \times 10^{-6} \mathrm{M}^{2} / \mathrm{c}_{\text {, }}$ $T=1273 \mathrm{~K}$, и размеров частиц $r_{0}=0,1 \mathrm{~mm}$ (кривая 1), $r_{0}=0,2 \mathrm{mм}$ (кривая 2), $r_{0}=0,3 \mathrm{Mm}$ (кривая 3).

Кривые обнаруживают гиперболический характер функции $t_{\mathrm{r}}\left(c_{0}\right)$, при этом ось ординат является ее асимптотой, поскольку при $c_{0} \rightarrow 0: t_{\text {г }} \rightarrow \infty$. Вместе с тем отметим, что на время выгорания частиц, размер которых $r_{0}=0,1$ мм, существенное влияние оказывает лишь значение начальной кон-

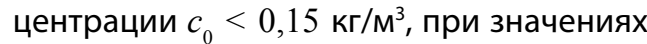
$c_{0} \geq 0,15 \mathrm{\kappa г} / \mathrm{M}^{3}$ время выгорания частиц практически не зависит от $c_{0}$.

На рис. 3 представлены кривые 1, 2, 3 зависимости времени выгорания от коэффициента диффузии $D$ соответственно для частиц $r_{0}=0,1 \mathrm{мm}, 0,2$ мм, 0,3 мм. Кривые построеныпри $\bar{S}_{i}=70 \mathrm{~cm}^{-1}, T=1273 \mathrm{~K}, c_{0}=0,23 \mathrm{\kappa г} / \mathrm{M}^{3}$.

Анализ приведенных кривых показывает, что коэффициент диффузии оказывает существенное влияние на время выгорания более крупных частиц, причем только при малых значениях $D$. Так, на отрезке $D \in\left[1 \times 10^{-6} \mathrm{M}^{2} / \mathrm{c} ; 4 \times 10^{-6} \mathrm{M}^{2} / \mathrm{c}\right]$ функция $t_{\mathrm{r}}(D)$ нелинейна, особенно при $r_{0} \geq 0,2$ мм. Однако при $r_{0}=0,1$ мм функция $t_{\text {г }}(D)$ слабо проявляет свою нелинейность (см. рис. 3, кривая 1), а при $D \geq 4 \times 10^{-6} \mathrm{M} / \mathrm{c}$, вообще, вырождается в горизонтальную прямую, что означает независимость времени выгорания от дальнейшего роста коэффициента диффузии. Для частиц $r_{0}=0,2$ мм, $r_{0}=0,3$ мм графики функций $t_{\mathrm{r}}(D)$ (см. рис. 3, кривые 2 и 3) вырождаются в горизонтальные прямые при $D>8 \times 10^{-6} \mathrm{M} / \mathrm{c}$.

И, наконец, на рис. 4 представлены кривые 1, 2, 3 функции $t_{\mathrm{r}}(T)$, построенные при $\bar{S}_{i}=70 \mathrm{~cm}^{-1}, D=5 \cdot 10^{-6} \mathrm{M} / \mathrm{c}, c_{0}=0,23 \mathrm{\kappa г} / \mathrm{M}^{3}$ для частиц $r_{0}=0,1 \mathrm{~mm}, 0,2 \mathrm{~mm}, 0,3 \mathrm{мm} \mathrm{соот-}$ ветственно.

Так, на рис. 1 представлены кривые зависимости $t_{\mathrm{r}}\left(\bar{S}_{i}\right)$, построенные при $T=1273 \mathrm{~K}, D=5 \times 10^{-6} \mathrm{M}^{2} / \mathrm{c}, c_{0}=0,23 \mathrm{\kappa г} / \mathrm{M}^{3}$ для частиц различного размера, при этом кривая 1 соответствует частице размером $r_{0}=0,1$ мм, кривая 2 - частице
Кривые 1, 2, 3 (см. рис. 4) - вогнутые с различной положительной кривизной, величина которой зависит как от температуры выгорания, так и от первоначального размера частиц $r_{0}$. Анализируя кривые, можно отметить, что чем 
больше $r_{0}$, тем больше кривизна и, следовательно, больше время выгорания частиц. Однако кривизна имеет место только на отрезке $T \in[1000 \mathrm{~K}, 1250 \mathrm{~K}]$.

При $T \geq 1250$ К все кривые вырождаются и сливаются в одну горизонтальную прямую, указывая на независимость времени выгорания от дальнейшего роста температуры горения.

\section{ОПРЕДЕЛЕНИЕ ВРЕМЕНИ ВЫГОРАНИЯ ГРУБОДИСПЕРСНОЙ ПЫЛЕГАЗОВОЗДУШНОЙ СМЕСИ В ЧАСТНЫХ СЛУЧАЯХ}

Из анализа формулы (8) следует, что время выгорания $t_{\text {г }}$ частиц определяется двумя слагаемыми в квадратных скобках. При определенных условиях соотношение между ними может быть различным и, следовательно, различными будут режимы горения частиц.

Здесь возможны различные случаи, для выявления которых, прежде всего, примем 5\%-ную погрешность вычислений. Это значит, что можем пренебречь одним из упомянутых слагаемых по сравнению с другим, если одно из них в 20 раз больше другого. Например:

$$
\frac{\bar{S}_{i} r_{0}^{2} k}{6 D} \leq \frac{1}{20} \ln \left(1+\frac{\bar{S}_{i} r_{0}}{3}\right) \text {. }
$$

Тогда вторым слагаемым в формуле (8) можем пренебречь по сравнению с первым, в силу чего формула (8) приобретает вид:

$$
t_{\mathrm{r}, \mathrm{kin}}=\frac{3 \gamma_{\mathrm{T}}}{\bar{S}_{i} k c_{0}} \ln \left(1+\frac{\bar{S}_{i} r_{0}}{3}\right)
$$

и содержит только константу реакции $k$, но не содержит коэффициент D. Следовательно, формула (10) определяет время выгорания частиц в кинетической области.

Если же, наоборот,

$$
\ln \left(1+\frac{\overline{S_{i}} r_{0}}{3}\right) \leq \frac{1}{20} \frac{\overline{S_{i}} r_{0}^{2} k}{6 D},
$$

то в формуле (8) можем пренебречь первым слагаемым по сравнению со вторым, вследствие чего формула (8) приводится к виду:

$$
t_{\mathrm{r}, \mathrm{dif}}=\frac{r_{0}^{2} \gamma_{\mathrm{T}}}{2 D c_{0}}
$$

и определяет время выгорания частиц в диффузионной области, поскольку формула (12) содержит коэффициент диффузии $D$, но не содержит константу реакции $k$.

Из формул (10) и (12) следует, что как в кинетической области, так и в диффузионной время выгорания частиц увеличивается с увеличением начального радиуса $r_{0^{\prime}}$ причем сильнее в диффузионной области, поскольку формула (12) содержит $r_{0}^{2}$, в то время как формула (10) содержит только $r_{0^{\prime}}$ к тому же под знаком логарифма.

Формулы (10) и (12) существенно проще, чем формула (8), но прежде, чем их использовать, необходимо гарантированно знать, в какой именно области происходит реакция горения. Если в качестве исходных данных заданы $r_{0}, \bar{S}, D, T$, то, подставив их в неравенства (9) или (11), можно убедиться, что одно из них выполняется.
Если же они не выполняются, то выгорание частиц происходит в промежуточной области, и для определения времени их выгорания необходимо использовать формулу (8). Если же нужно определить какие-либо параметры частиц, чтобы реакция горения протекала в заданной области, то необходимо воспользоваться равенствами (в их предельных случаях), вытекающими из неравенств (9) или (11).

В качестве примера к сказанному рассмотрим следующую задачу, исходными данными в которой являются $D=10^{-5} \mathrm{M}^{2} / \mathrm{c}, \bar{S}_{i}=70 \mathrm{~cm}^{-1}, T=1100 \mathrm{~K}$. Требуется определить наименьший начальный радиус $r_{0^{\prime}}$ при котором процесс горения протекает в кинетической области. Для решения задачи рассмотрим уравнение

$$
\ln \left(1+\frac{\bar{S}_{i} r_{0}}{3}\right)-20 \frac{\overline{S_{i}} r_{0}^{2} k}{6 D}=0,
$$

являющееся предельным случаем неравенства (9). Поскольку уравнение (13) является трансцендентным относительно искомой величины $r_{0}$, то найти его аналитическое решение затруднительно. Поэтому воспользуемся графическим методом решения. Для этого вначале построим функцию

$$
y\left(r_{0}\right)=\ln \left(1+\frac{\bar{S}_{i} r_{0}}{3}\right)-20 \frac{\overline{S_{i}} r_{0}^{2} k}{6 D},
$$

представляющую собой левую часть уравнения (13), а затем построим ее график, изображенный на рис. 5.

Кривая функции $y\left(r_{0}\right)$ является выпуклой, имеющей максимальное значение в точке $2,012 \cdot 10^{-4} \mathrm{M}$, и дважды пересекает ось абсцисс в точках $r_{0(1)}=0$ и $r_{0(2)}=4,138 \times 10^{-4} \mathrm{M}$, которые являются корнями уравнения (13). Первый из них тривиален, второй же является искомым решением поставленной задачи. Таким образом, в условиях рассматриваемой задачи при размере частиц $r_{0}=4,138 \times 10^{-4} \mathrm{M}$ реакция горения будет протекать в кинетической области.

При $r_{0}<4,138 \times 10^{-4}$ м нестрогое неравенство (9) превращается в строгое, что означает усиление кинетического режима протекания реакции. Наоборот, при $r_{0}>4,138 \times 10^{-4} \mathrm{M}$ реакция горения будет переходить из кинетической области в промежуточную область.

В следующей задаче найдем значение относительной внутренней поверхности $\bar{S}_{i^{\prime}}$ при котором реакция горе-

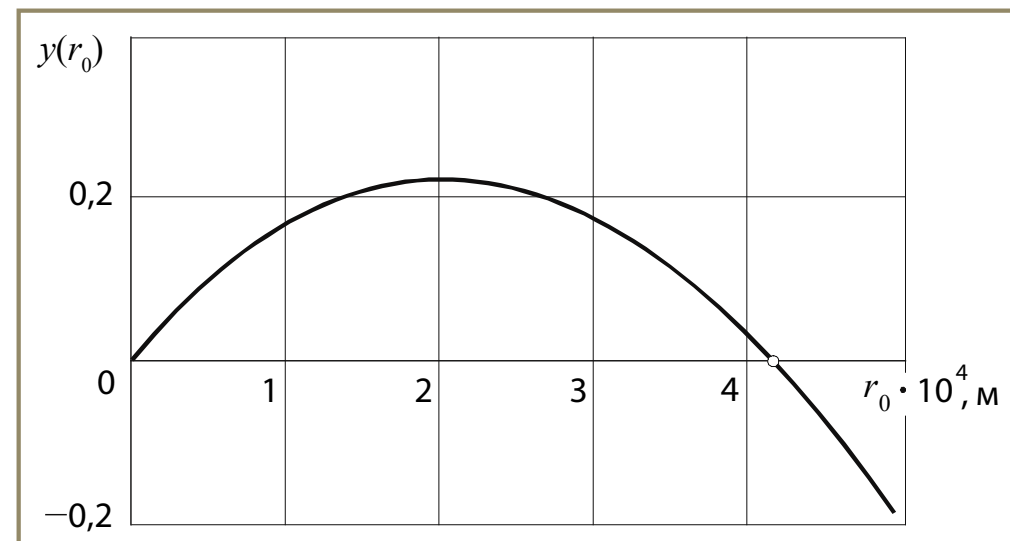

Puс. 5. График функции у $\left(r_{0}\right)$

Fig. 5. Graph of the function $y\left(r_{0}\right)$ 


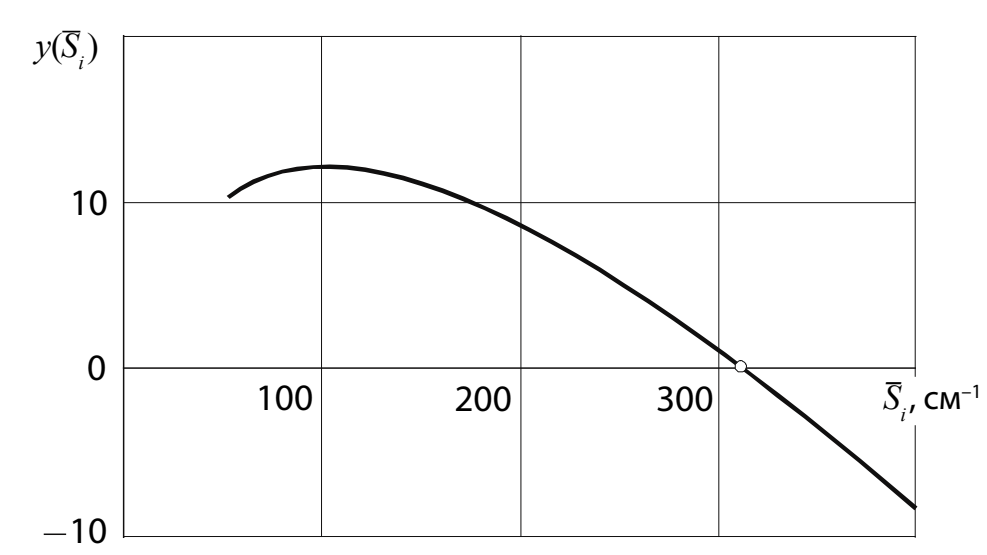

Puс. 6. График функиии у $\left(\bar{S}_{i}\right)$

Fig. 6. Graph of the function $y\left(\bar{S}_{i}\right)$ а) независимо от размера угольных, частиц с ростом величины внутренней реагирующей поверхности $\bar{S}_{i}$ время их выгорания уменьшается, хотя и не очень существенно, особенно для частиц малых размеров.

б) на время выгорания частиц, размер которых не превышает $r_{0}=0,1$ мм, существенное влияние оказывают лишь значения начальной концентрации $c_{0}<0,15 \mathrm{kг} / \mathrm{M}^{3} ;$ при значе-

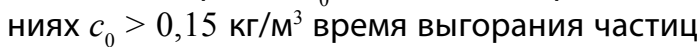
практически не зависит от $c_{0}$. Для более крупных частиц время выгорания не зависит от

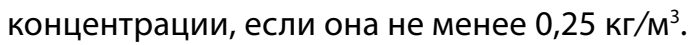

в) коэффициент диффузии оказывает существенное влияние на время выгорания частиц размером более 0,4 мм, причем только при малых значениях коэффициента диффузии $D$. Для частиц, не превышающих 0,1 мм при ния протекает в диффузионной области, если $D=10^{-6} \mathrm{M}^{2} / \mathrm{c}$, $r_{0}=8,5 \times 10^{-4} \mathrm{M}, T=1273 \mathrm{~K}$.

Схема решения этой задачи такая же, как и предыдущей, с той лишь разницей, что вместо уравнения (13) используем уравнение

$$
20 \ln \left(1+\frac{\bar{S}_{i} r_{0}}{3}\right)-\frac{\bar{S}_{i} r_{0}^{2} k}{6 D}=0,
$$

являющееся предельным случаем неравенства (11). Далее строим функцию:

$$
y\left(\overline{S_{i}}\right)=20 \ln \left(1+\frac{\overline{S_{i}} r_{0}}{3}\right)-\frac{\overline{S_{i}} r_{0}^{2} k}{6 D},
$$

а затем ее график (рис. 6).

С графика снимаем значение $\bar{S}_{i}=310,62 \mathrm{~cm}^{-1}$, при котором функция $y\left(\bar{S}_{i}\right)=0$, а уравнение (15) тождественно удовлетворяется. Следовательно, значение $\bar{S}_{i}=310,62 \mathrm{~cm}^{-1}$ является искомым решением данной задачи. При значениях $\bar{S}_{i}>310,62 \mathrm{~cm}^{-1}$ происходит усиление диффузионного режима, а при $\bar{S}_{i}<310,62 \mathrm{~cm}^{-1}-$ переход реакции горения в промежуточную область.

Если реакция горения протекает в кинетической области и известны $r_{0^{\prime}} \bar{S}_{i^{\prime}} T$, то коэффициент диффузии $D$ должен быть не менее:

$$
D \geq \frac{10 \bar{S}_{i} r_{0}^{2} k}{3 \ln \left(1+\frac{\bar{S}_{i} r_{0}}{3}\right)},
$$

что следует из неравенства (9).

Если же реагирование происходит в диффузионной области и известны $r_{0}, \bar{S}_{i^{\prime}} T$, то коэффициент диффузии $D$ должен быть не более

$$
D \leq \frac{\bar{S}_{i} r_{0}^{2} k}{120 \ln \left(1+\frac{\overline{S_{i}} r_{0}}{3}\right)},
$$

что вытекает из неравенства (11).

\section{Выводы}

1. Получена формула, определяющая время выгорания покоящихся грубодисперсных угольных частиц, анализ которой позволил установить:
$D>4 \cdot 10^{-6} \mathrm{M} / \mathrm{c}$, время выгорания не зависит от диффузии.

2. Получены трансцендентные уравнения, позволяющие установить соотношения между параметрами ПГВС при протекании процесса горения соответственно в кинетической, диффузионной и промежуточной области.

\section{Список литературы}

1. Амельчугов С.П., Быков В.И., Цыбенова С.Б. Самовозгорание пыли бурого угля. Эксперимент, определение кинетических параметров и численное моделирование // Физика горения и взрыва. 2002. № 3. С. 48 - 54.

2. Васильев А.А., Васильев В.А. Расчетные и экспериментальные параметры горения и детонации смесей на основе метана и угольной пыли // Вестник Научного центра по безопасности работ в угольной промышленности. 2016. № 2. С. 8-39.

3. Захаров Е.И., Качурин Н.М., Малахова Д.Д. Механизм процесса самонагревания угля и перехода его в самовозгорание // Известия ТулГУ. Науки о Земле. 2013. Вып. 2. С. 42 - 50.

4. Математическая теория горения и взрыва / Я.Б. Зельдович, Г.И. Баренблатт, В.Б. Либрович, Г.М. Махвиладзе. М.: Наука, 1980. 478 с.

5. Канторович Б.В. Основы теории горения и газификации твердого топлива. М.: Издательство АН СССР, 1958. $600 \mathrm{c}$.

6. Каталог углей СССР, склонных к самовозгоранию / Н.И. Линденау, В.М. Маевская, Е.С. Вахрушева и др. М.: Недра, 1982. 416 с.

7. Портола В.А. Опасность самовозгорания угольной пыли // Безопасность труда в промышленности. 2015. № 6. С. 36-39.

8. Федоров А.В. Воспламенение газовзвесей в режиме взаимодействующих континуумов // Физика горения и взрыва. 1998. № 4. С. 57-64.

9. Франк-Каменецкий Д.А. Диффузия и теплопередача в химической кинетике. М.: Наука, 1987. 502 с.

10. Вильямс Ф.А. Теория горения. Пер. с англ. М.: Наука, 1971.616 с.

11. Сполдинг Д.Б. Основы теории горения. Пер. с англ. М.-Л.: Госэнергоиздат, 1959. 321 с.

12. Bekdemir C., Somers B., de Goey P. DNS with detailed and tabulated chemistry of engine relevant igniting systems // Combustion and Flame. 2014. Vol. 161, № 1. Pp. 210-221. 
13. Ju Y. G., Maruta K. Microscale combustion:Technology development and fundamental research // Progress in Energy and Combustion Science. 2011. Vol. 37, № 6. Pp. 669-715.

14. Rockwell S.R. Influence of coal dust on premixed turbulent methane-air flames / Scott R. Rockwell, Ali S. Rangwala // Combustion and Flame. V. 160, Issue 3. March 2013. Pp. 635-640.
15. Takase K., Li X., Nakamura H., Tezuka T., Hasegawa S., Katsuta M., Kikuchi M., Maruta K. Extinction characteristics of $\mathrm{CH} 4 / \mathrm{O}-2 / \mathrm{Xe}$ radiative counterflow planar premixed flames and their transition to ball-like flames // Combustion and Flame. 2013. T. 160, № 7. Pp. 1235-1241.

16. Xin Y.X., Yoo C.S., Chen J.H., Law C.K. A DNS study of self-accelerating cylindrical hydrogen-air flames with detailed chemistry // Proceedings of the Combustion Institute. 2015. Vol. 35. Pp. 753-760.

SAFETY

UDC 622.272:516.02 @ S.V. Cherdantsev, Kh.U. Lee, Yu.M. Filatov, P.A. Shlapakov, 2018

ISSN 0041-5790 (Print) • ISSN 2412-8333 (Online) • Ugol' - Russian Coal Journal, 2018, № 1, pp. 44-49

\section{Title}

INFLUENCE OF PARAMETERS OF THE ROUGHLY DISPERSED DUST GAS MIXTURES ATTHE TIME OF THEIR BURN-OUT IN MINE WORKINGS OF COAL MINES

DOI: http://dx.doi.org/10.18796/0041-5790-2018-1-44-49

\section{Authors}

Cherdantsev S.V. ${ }^{1}$, Lee Kh.U. ${ }^{1}$, Filatov Yu.M. ${ }^{1}$, Shlapakov P.A. ${ }^{1}$

1 "Scientific centre "VostNII", JSC, Kemerovo, 650002, Russian Federation

\section{Authors' Information}

Cherdantsev S.V., Doctor of Engineering Sciences, Leading Researcher, tel.: +7 (913) 29-65-591, e-mail: svch01@yandex.ru

Lee Kh.U., Doctor of Engineering Sciences, Professor, Deputy General Director-Academic Secretary, tel.: +7 (3842) 64-28-95, e-mail: leeanatoly@mail.ru Filatov Yu.M., PhD (Engineering), General Director, tel.: +7 (3842)64-30-99, e-mail: main@nc-vostnii.ru

Shlapakov P.A., Laboratory Head, tel.: +7 923-510-37-21,

e-mail: shlapak1978@mail.ru

\section{Abstract}

The process of burning coarse dust-laden flue gas mixtures in the atmosphere of mine workings. Burning mixtures is treated as A combination of two processes: heterogeneous, occurring on the external surface of coal particles and homogeneous flowing inside their volume. On the basis of the equation expressing the law of conservation of mass, the formula that determines the burnout time of the coarse dust-laden flue gas mixtures. Plotted time of burnout of the mixture from the parameters of the mixture. Established the influence of different parameters of the mixtures at the time of burnout. The analysis of numerical values and functions that define the time of burnout of the coarse dust-laden flue gas mixtures. The conditions under which the combustion of the coarse dust-laden flue gas mixtures occurs in a variety of combustion modes. Figures:

Fig. 1. Schedules of dependence of time of burning out $t$ of particles from the size of their inner surface $\bar{S}$

Fig. 2. Schedules of dependence of time of burning $t_{\mathrm{r}}$ out of particles of initial concentration $c_{0}$

Fig. 3. Schedules of dependence of time of burning $t_{\mathrm{r}}$ out of particles from the diffusion coefficient $D \cdot 10^{6}$

Fig. 4. Schedules of dependence of time $t_{\mathrm{r}}$ of the burning particle temperature $T$ Fig. 5. Graph of the function $y\left(r_{0}\right)$

Fig. 6. Graph of the function $y\left(\bar{S}_{i}\right)$

\section{Keywords}

Mining tunneling, Coarse dust-laden flue gas mixture, Chemical reaction rate, Arrhenius equation, Diffusion coefficient, Reaction on the surface of the pores, Total resistance of the chemical reaction.

\section{References}

1. Amelchugov S.P., Bykov V.I. \& Tsybenova S.B. Samovozgoranie pyli burogo uglya. Eksperiment, opredelenie kineticheskikh parametrov i chislennoe modelirovanie [Spontaneous combustion of dust brown HS-La. Experiment, determination of kinetic parameters and numerical simulation]. Fizika goreniya i vzryva - Physics of combustion and explosion, 2002, No. 3, pp. 48-54.

2. Vasiliev A.A., Vasiliev V.A. Raschetnye i eksperimental'nye parametry goreniya i detonatsii smesey na osnove metana i ugol'noy pyli [Calculated and experimental parameters of combustion and detonation of mixtures of methane and coal dust]. Vestnik Nauchnogo tsentra po bezopasnosti rabot $v$ ugol'noy promyshlennosti-Scientific Bulletin of the center for safety in the coal industry, 2016, No. 2, pp. 8-39.

3. Zakharov E.I., Kachurin N.M. \& Malakhov D.D. Mekhanizm protsessa samonagrevaniya uglya i perekhoda ego v samovozgoranie [Mechanism of the process of coal self-heating and auto-ignition]. Izvestiya TuIGU. Naukio ZemleIzvestiya TuIGU. Earth Sciences, 2013, Vol. 2, pp. 42-50.

4. Zeldovich Ya.B., Barenblatt G.I., Librovich V.B., Makhviladze G.M. Matematicheskaya teoriya goreniya i vzryva [Mathematical theory of combustion and explosion]. Moscow, Nauka Publ., 1980, 478 p.

5. Kantorovich B.V. Osnovy teorii goreniya i gazifikatsii tverdogo topliva [Fundamentals of theory of combustion and gasification of solid fuels]. Moscow, Academy of Sciences USSR Publ., 1958, 600 p.

6. Lindenau N.I., Mayevskaya M.V., Vakhrusheva E.S. etc. Katalog ugley SSSR, sklonnykh k samovozgoraniyu [Directory of coal of the USSR, prone to spontaneous combustion]. Moscow, Nedra Publ., 1982, 416 p.

7. Portola V.A. Opasnost' samovozgoraniya ugol'noy pyli [The danger of spontaneous combustion of coal dust]. Bezopasnost' truda $v$ promyshlennosti - Safety in industry, 2015, No. 6, pp. 36-39.

8. Fedorov A.V. Vosplamenenie gazovzvesey $v$ rezhime vzaimodeystvuyushchikh kontinuumov [Ignition of gas suspensions in the mode of interacting continua]. Fizika goreniya i vzryva-Physics of combustion and explosion, 1998, No. 4, pp. 57-64.

9. Frank-Kamenetsky D.A. Diffuziya i teploperedacha $v$ khimicheskoy kinetike [Diffusion and heat transfer in chemical kinetics]. Moscow, Nauka Publ., 1987, 502 p.

10. Williams F.A. Teoriya goreniya [Combustion theory]. Per. from English. Moscow, Nauka Publ., 1971, 616 p.

11. Spolding D.B. Osnovy teorii goreniya [Fundamentals of the theory of combustion]. Per. from English. Moscow-Leningrad, Gosenergoizdat Publ., 1959, $321 \mathrm{p}$.

12. Bekdemir C., Somers B., de Goey P. DNS with detailed and tabulated chemistry of engine relevant igniting systems. Combustion and Flame, 2014, Vol. 161, No. 1, pp. 210-221.

13. Ju Y.G. \& Maruta K. Microscale combustion: Technology development and fundamental research. Progress in Energy and Combustion Science, 2011, Vol. 37, No. 6, pp. 669-715.

14. Rockwell S.R., Rangwala A.S. Influence of coal dust on premixed turbulent methane-air flames. Combustion and Flame, Vol. 160, Issue 3, March 2013, pp. 635-640.

15. Takase K., Li X., Nakamura H., Tezuka T., Hasegawa S., Katsuta M., Kikuchi M., Maruta K. Extinction characteristics of $\mathrm{CH}_{4} / \mathrm{O}-2 /$ Xe radiative counterflow planar premixed flames and their transition to ball-like flames. Combustion and Flame, 2013, Vol. 160, No. 7, pp. 1235-1241.

16. Xin Y.X., Yoo C.S., Chen J.H., Law C.K. A DNS study of self-accelerating cylindrical hydrogen-air flames with detailed chemistry. Proceedings of the Combustion Institute, 2015, Vol. 35, pp. 753-760. 


\section{АО «СУЭК-Кузбасс» досрочно выполнило план 2017 года по добыче угля}

Компания “СУЭК-Кузбасс» в первой декаде декабря 2017 г. досрочно выполнила годовой производственный план по добыче угля 6 объеме 35 млн 906 тыс. $\mathrm{m}$.

Основной вклад в успех внесли шахты имени В.Д.Ялевского, имени С.М.Кирова, «Талдинская-Западная - 1», имени А.Д. Рубана, разрезы «Заречный» и «Камышанский».

Среди очистных коллективов безусловным лидером является бригада Героя Кузбасса Евгения Косьмина шахты имени В.Д. Ялевского. За 11 с небольшим месяцев 2017 г. ею выданы на-гора рекордные для России 5,3 млн т угля.

Более 4,4 млн т добыто бригадой Героя Кузбасса Владимира Березовско20 шахты «Талдинская-Западная - 1».

Более 3 млн т угля с начала года добыли бригады Олега Германа, Юрия

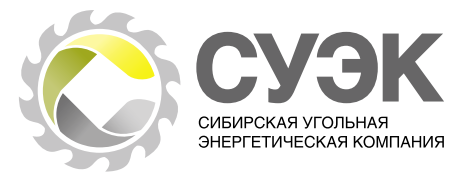

Солдатенко (обе - шахта имени С.М. Кирова), Анатолия Кайгородо-

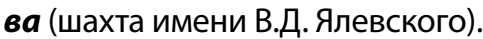

В 2017 г. на предприятиях АО «СУЭККузбасс» очистными бригадами, экипажами экскаваторов и буровых станков установлено шесть мировых рекордов производительности для различных видов горного оборудования. Напомним, что годовой план по подготовке горных выработок в компании выполнен еще в конце ноября.

Одним из главных слагаемых производственных успехов является масштабная инвестиционная программа, реализуемая на предприятиях ком- пании. Общий объем вложений в 2017 г. составляет 19,7 млрд руб. А за последние пять лет Сибирская угольная энергетическая компания инвестировала в «СУЭК-Кузбасс» более 68 млрд руб.

Основные направления инвестиций - промышленная безопасность и охрана труда (в среднем около 1 млрд руб. в год), замена оборудования, внедрение новых технологий и развитие логистических цепочек. В числе самых значимых проектов по обновлению техники стало приобретение двух комплектов механизированной крепи: в 2016 г. - для шахтоуправления «Талдинское-Западное», в 2017 г. - для шахты имени С.М. Кирова. Также более 8 млрд руб. вложено в строительство нового участка «Магистральный» в шахтоуправлении имени А.Д. Рубана.

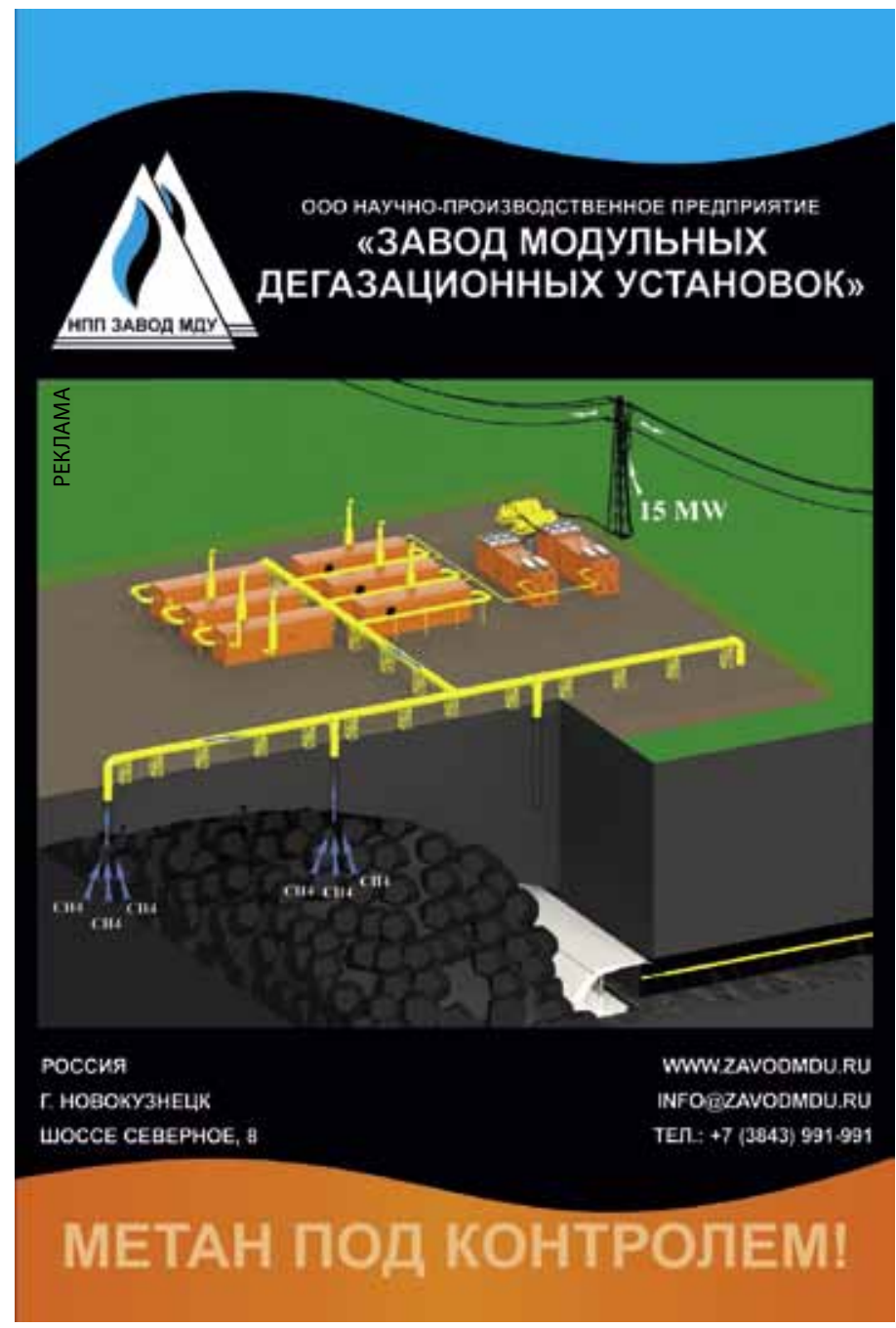

\section{0 «Приморскуголь»}

\section{досрочно выполнило}

план 2017 года по добыче и отгрузке угля

7 декабря 2017 2. коллектив ООО «Приморскуголь" досрочно выполнил годовую производственную программу 2017 года по добыче и отгрузке угля.

Объем добычи составил 3,252 млн т, отгрузки 3,261 млн т.

В течение года приморские угольщики уверенно наращивали показатели добычи и отгрузки с опережением установленного графика.

Разрезоуправление «Новошахтинское» - самое крупное предприятие ООО «Приморскуголь» - годовой план по добыче и отгрузке угля выполнило уже в ноябре. В ноябре 2017 г. коллектив РУ «Новошахтинское» впервые за 35-летнюю историю предприятия отгрузил потребителям рекордное количество угля в объеме 525 тыс. т.

В 2017 г. ООО «Приморскуголь» приступило к строительству нового разреза «Некковый» на Липовецком каменноугольном месторождении. 28 ноября разрез добыл и отгрузил первую тонну угля. 


\title{
Мировой инновационный проект «Индустрия-4.0» - возможности применения в угольной отрасли России. 3. Систематизация основных элементов проекта «Индустрия-4.0 по базовым процессам горного производства
}

\author{
(Окончание. Начало см. журналы «Уголь», № 10-2017, с. 44-50, № 11-2017, с. 46-53)
}

DOI: http://dx.doi.org/10.18796/0041-5790-2018-1-51-57

ПЛАКИТКИН Юрий Анатольевич

Доктор экон. наук, академик РАЕН, заместитель директора по науке ИНЭИ РАН, 117186, 2. Москва, Россия, e-mail: uplak@mail.ru

\section{ПЛАКИТКИНА Людмила Семеновна}

Канд. техн. наук, член-корр. РАЕН, руководитель Центра исследования Угольной промышленности мира и России ИНЭИ РАН, 117186, 2. Москва, Россия, e-mail: luplak@rambler.ru

В статье представлены результаты исследований авторов по оценке стоимости инноваций в прогнозном периоде. Показана взаимосвязь инноваций с инвестициями, направляемыми в сектора мировой экономики. Приведены основные прорывные технологии предстоящего периода времени, а также оценка их влияния на объемы производства в отраслях ТЭК. Особое значение авторы статьи в своих исследованиях уделили систематизации технологических решений, которыемогут быть реализованы в угольной промышленности России. Показано, что эти решения могут базироваться на реализации в предстоящем периоде времени основных направлений проекта «Индустрия-4.0», включая прорывные технологии, комплектующие производственные киберфизические системы. Авторы статьи приводят аргументацию возможности применения в прогнозном периоде технологических решений, наработанных российскими учеными в 1980-х годах. Обосновано, что в новых условиях технологические платформы в угольной отрасли должны быть построены не как набор отдельных технологических решений, а как система технологических элементов, в которой достигается их оптимальное сочетание. Установлено, что подобная система ранее существовала как постоянно поддерживаемый интеллектуальный проект «Шахта будущего». Ключевые слова: стоимость инноваций, инвестиции, прорывные технологии, систематизация технологических решений, технологические платформы, угольная промышленность, прочессы горного производства, проект «Индустрия-4.0», искусственный интеллект, киберфизические системы, производственные блоки, интеллектуальные системы.

\section{ВВЕДЕНИЕ}

Приведенные в предыдущей статье индикаторы развития угольной промышленности России, соответствующие будущим мировым технологическим преобразованиям и мировому технологическому прорыву, представляют собой требуемые финансово-экономические ориентиры функционирования отрасли в прогнозном периоде [1]. На основе соизмерения с планируемыми результатами эти индикаторы позволяют угольному бизнесу оценивать по совокупности параметров свой потенциал по дальнейшей работе на угольном рынке. Вместе с тем такие ориентиры должны быть «подкреплены» планируемыми технологическими решениями, способными обеспечить требуемый уровень развития отрасли.

В этой связи авторы настоящей статьи провели исследования по выявлению прорывных технологий, которые могут комплектовать производственные киберфизические системы, являющиеся в совокупности с промышленным Интернетом «вещей» основой реализации проекта «Индустрия-4.0» [2]. Эти технологии и сочетающиеся с ними прочие технологические решения явились основой при разработке укрупненной систематизации технологических элементов по базовым процессам горного производства. Представленная классификация не является всеобъемлющей, однако она может задать вектор будущих технологических преобразований в отрасли. Эти преобразования, по мнению авторов, должны стать основой для подготовки новой редакции Стратегии развития угольной промышленности, учитывающей масштабные мировые технологические преобразования будущего периода [3].

\section{ЗАПРОС МИРОВОЙ ЭКОНОМИКИ}

\section{НА НОВЫЕ ИНВЕСТИЦИИ И ИННОВАЦИИ}

В предыдущей статье [1] приведены основные требования, которые предъявляются к параметрам развития угольной промышленности России в период прогнозируемого мирового инновационно-технологического прорыва. Главными показателями, отражающими суть будущих преобразований, являются высокий рост производительности труда, снижение стоимости выпускаемой продукции и существенное повышение эффективности инвестиций. Причем последнее достигается как за счет увеличения единичной 


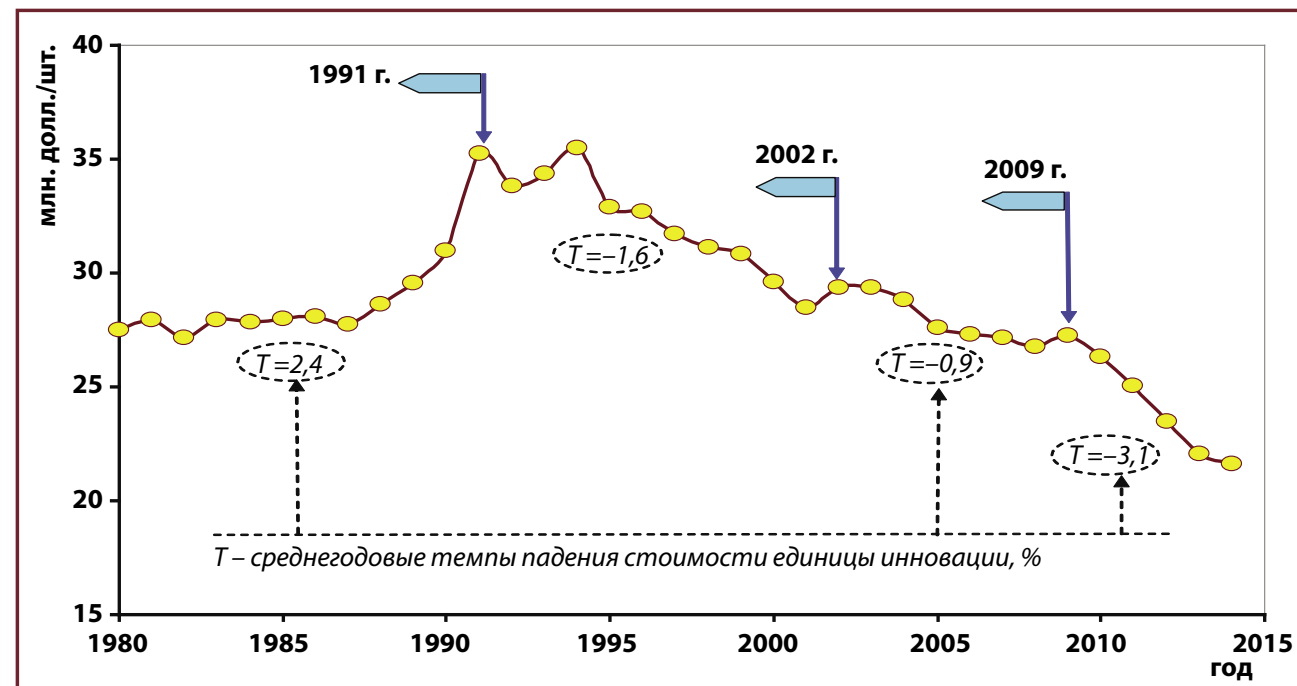

Рис. 1 Динамика стоимости (по ВВП) единицы инновационного потока (оценка по мировому ВВП, отнесенному к мировому потоку патентных заявок), млн дол. США/um.

технологии будут комплектовать будущие производственные киберфизические системы в отраслях экономики?

Конечно, таких технологий, учитывая их отраслевой профиль, может быть достаточно много. Однако существуют «прорывные» технологии, которые будут являться базовыми во многих отраслевых киберфизических системах.

Авторы настоящей статьи на основе системного анализа выделили пять крупных базовых технологий, которые могут изменить облик современной экономики: нанотехнологии, 3D-принтерные технологии,

производительности, так и за счет снижения стоимости используемых инновационных товаров. Подтверждается ли это положение современным статистическим анализом инновационного развития? Да, подтверждается.

В процессе исследования авторами настоящей статьи был проведен анализ динамики отношения ВВП мира к годовому потоку, так называемых мировых «тройных» технологических патентных заявок. Динамика этого потока, по сути дела, потенциально определяет интенсивность мирового инновационно-технологического процесса [4].

Изучение динамики вышеприведенного соотношения за последние 35 лет позволило сделать выводы о направленности вектора стоимости единицы инноваций (рис. 1) [5].

В процессе исследования установлено, что отношение ВВП мира к мировому инновационному потоку фактически оценивает стоимость единицы инноваций:

$$
C=\frac{B B \Pi}{I}=\frac{a}{b} * S
$$

где: ВВП - ВВП мира, дол. США; I - поток мировых патентных заявок, шт./год; $S$ - стоимость единицы инноваций, дол. США/шт.; $a$ и в - соответственно доли добавленной стоимости и новых технологий в мировой произведенной продукции.

Не вдаваясь в детальный анализ представленной кривой (см. рис. 1), на которой помечены «интересные» политологические «точки», отметим, что современный ее участок, начавшийся одновременно с мировым финансовоэкономическим кризисом (с 2009 г.), обладает скоростью снижения, которая в 2-3 раза превышает аналогичное снижение на предшествующих участках. Стоимость единицы инноваций ускоренно снижается. Это свидетельствует о том, что в мировой экономике в настоящее время формируется запрос на дешевые инновационные товары и услуги, что подтверждает ранее полученные выводы относительно снижения стоимости инвестиций (как совокупности, в том числе инновационных товаров) в угольной промышленности в прогнозном периоде.

\section{ПРОРЫВНЫЕ ТЕХНОЛОГИИ БУДУЩЕГО ПЕРИОДА}

Какими же технологиями будет характеризоваться прогнозируемый технологический прорыв в экономике? Какие информационно-коммуникационные технологии, роботизация и биотехнологии.

Оценка интенсивности развития «прорывных» технологий в промышленности, строительстве, транспорте и медицине, проведенная авторами статьи, представлена на рис. 2.

Характерной особенностью приведенныхвыше «прорывных» технологий является то, что «пик» их промышленного освоения будет приходиться на 2040-2060 гг., а это период развития «сильного» и «очень сильного» искусственного интеллекта. Отметим, что с ростом «силы» искусственного интеллекта повышаются показатели экономической эффективности применяемых киберфизических систем.

Если, в соответствии с проведенными расчетами, в угольной промышленности в период до 2035 г. производительность труда должна повыситься не менее чем в 3-4,3 раза [1], то можно лишь представить, каково будет это повышение в период «сильного» и «очень сильного» искусственного интеллекта (за пределами 2040 г.).

В процессе исследования авторы настоящей статьи оценили влияние этих «прорывных» технологий на развитие отраслей ТЭК. В целом, их применение будет оказывать «сильное» влияние на снижение мирового потребления топливно-энергетических ресурсов. Однако вклад каждой из «прорывных» технологий в снижение этого потребления будет различным (рис. 3).

На первом этапе (до 2025 г.) наибольшее воздействие будут оказывать информационно-коммуникационные технологии и 3D-принтерные технологии. На втором этапе (до 2035 г.) в большей мере начнут «заявлять» о себе технологии роботизации. Они в этом периоде фактически будут «входить» в зону сильного искусственного интеллекта. И, наконец, на третьем этапе (в период до 2050 г.) технологии роботизации и нанотехнологий станут доминирующими по своему воздействию на экономику и энергетику.

Сочетание роботизации и нанотехнологий может дать значительный технологический эффект в развитии разных секторов экономики. Линейка производных технологий может быть достаточно большой: от применения нанороботов до создания на основе нанотехнологий миниатюрных источников энергии для автономного использования в роботизированных системах. 


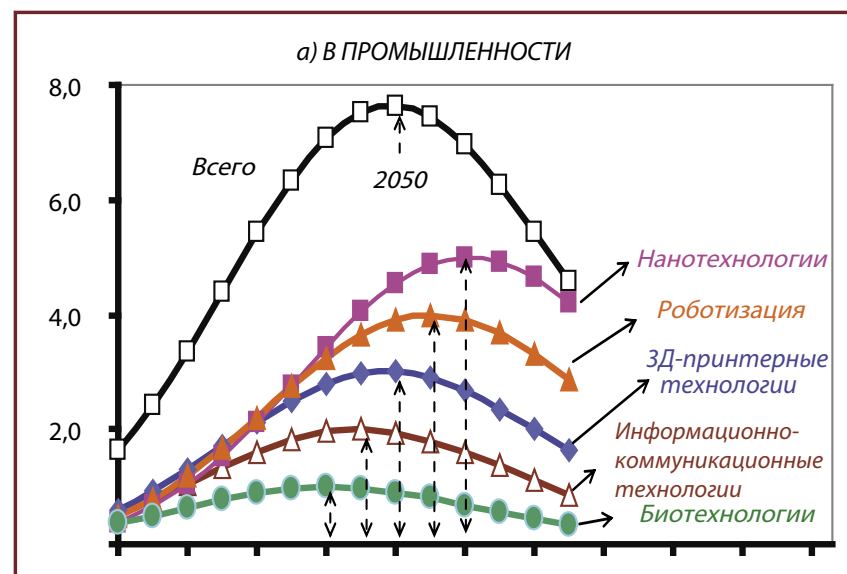

20102020203020402050206020702080209021002110 в) В СТРОИТЕЛЬСТВЕ

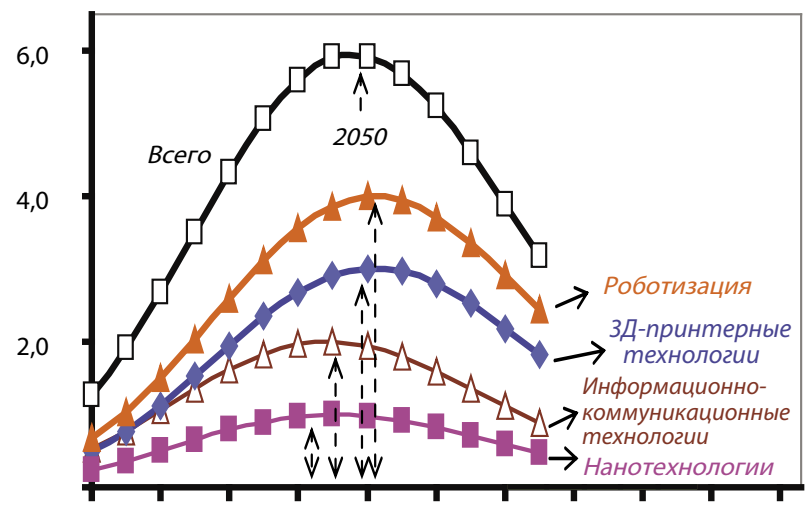

20102020203020402050206020702080209021002110

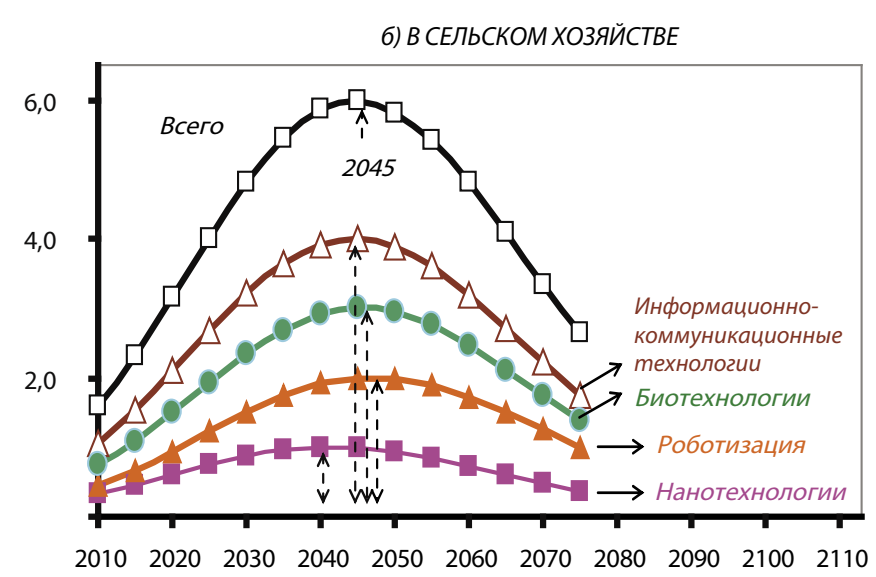

2) В МЕДИЦИНЕ

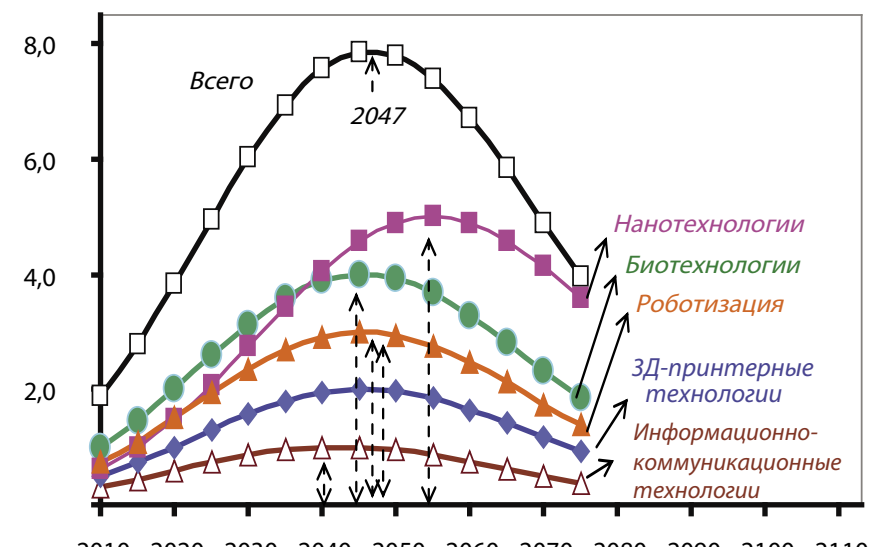

20102020203020402050206020702080209021002110

Рис. 2. Интенсивность реализации прорывных инновационных технологий в различных секторах мировой экономики

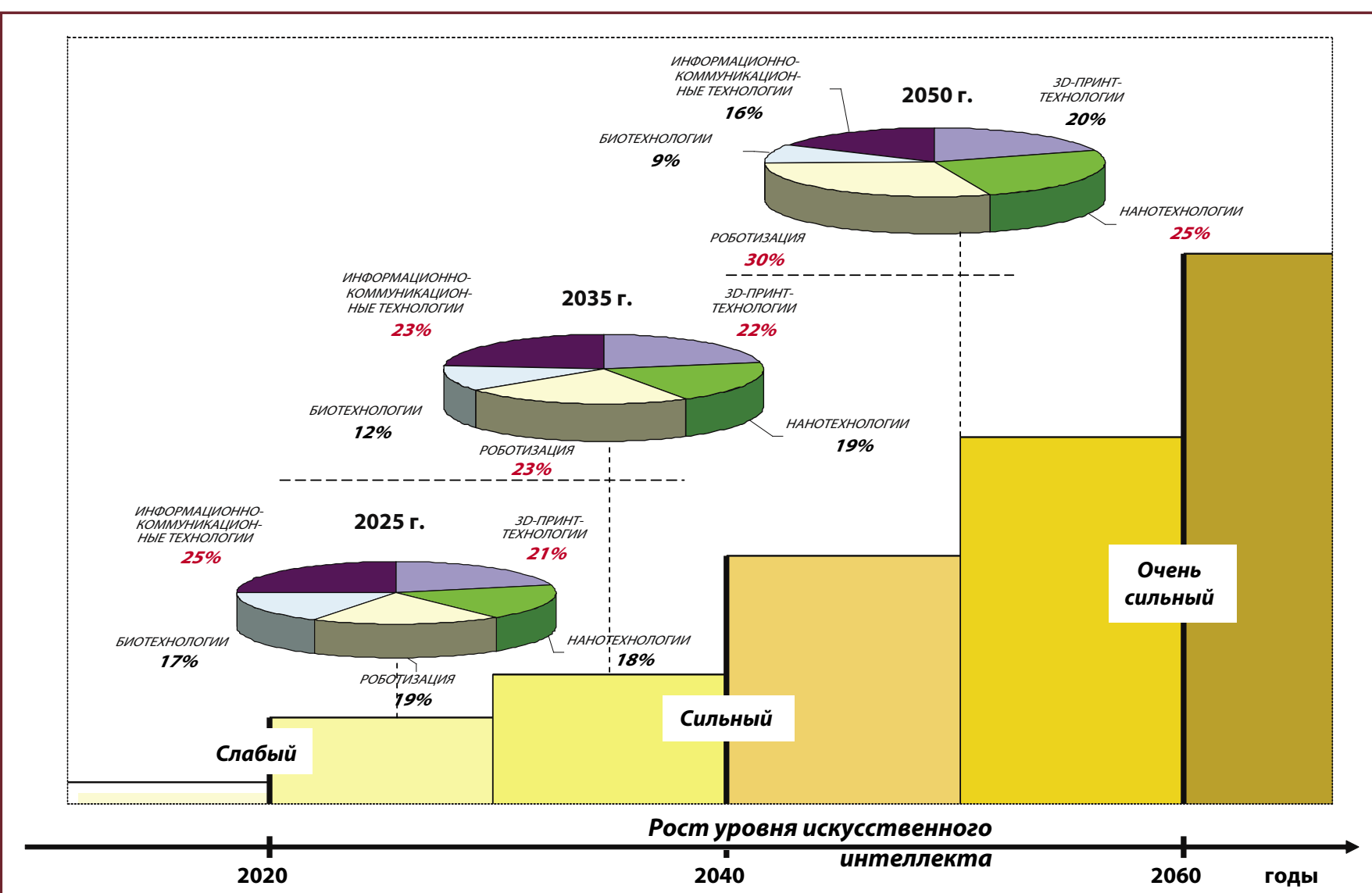

Рис. З. Воздействие прорывных технологий на объемы производства энергии в отраслях ТЭК 


\section{СИСТЕМАТИЗАЦИЯ ТЕХНОЛОГИЧЕСКИХ РЕШЕНИЙ ДЛЯ УГОЛЬНОЙ ПРОМЫШЛЕННОСТИ, ВЫТЕКАЮЩИХ ИЗ РЕАЛИЗАЦИИ ПРОЕКТА «ИНДУСТРИЯ-4.0»}

Основываясь на применении в прогнозном периодепроизводственных киберфизических систем, обусловленных реализацией проекта «Индустрия-4.0» и представленных выше прорывных технологий, в процессе исследования авторами настоящей статьи впервые была разработана укрупненная систематизация технологических элементов для угольной промышленности. Эта систематизация была аннотирована авторами в Аналитическом Центре при Правительстве РФ в августе 2017 г. на экспертном совещании, посвященном вопросам развития угольной промышленности (рис. 4).

Систематизацией (см. рис. 4) охвачены такие направления горного производства, как:

- разведка запасов и планирование горных работ;

- добыча угля;

- переработка угля и отходов производства;

- транспортирование угля и других грузов.

Отметим, что два главных элемента проекта «Индустрия-4.0» «прошивают» все процессы горного производства. Это «Интернет вещей», а также автоматизация и роботизация производственных процессов $[6,7,8,9,10,11]$.

Центральным элементом систематизации является использование киберфизических производственных систем в процессах добычи и подготовки запасов угля. Их функционирование основано на применении интеллектуальных роботизированных систем в автономных производственных блоках небольшой мощности. В частности, в блоках при подземной добыче угля могут быть использованы спроектированные и прошедшие промышленные испытания еще в 1980-х годах так называемые фронтальные агрегаты, осуществляющие одномоментную обработку всей плоскости очистного забоя. Это позволяет многократно увеличить производительность добычи угля.

По замыслу академика РАН В.В. Ржевского (автор статьи в то время активно участвовал в подготовке обосновывающих материалов), производственные блоки должны составлять технологическую систему, способную к «саморазвитию». Предполагалось, что отработка каждого блока должна давать возможность для финансового обеспечения подготовки и отработки последующего блока [12]. Но не только это. Продолжительность отработки блоков должна быть небольшой, примерно 5-7 лет. Такая система дает возможность на каждом последующем блоке применять более совершенное оборудование и технологии, что позволяет в наибольшей степени использовать новейшие технико-технологические достижения. Для ускорения работ по вскрытию и подготовке запасов предполагалось проведение стволов осуществлять методом выбуривания.

Пространственно-планировочные решения также должны были претерпеть трансформацию: они должны были изменить прямолинейную геометрию раскройки шахтных полей на криволинейную. Не зря в это время под руководством академика РАЕН А.С. Бурчакова, профессора, доктора техн. наук А.Н. Килячкова проводился целый комплекс исследовательских работ и производственных испытаний по так называемым «разворотам» механизированных комплексов. Это давало существенную экономию на концевых участках отработки выемочных столбов за счет ликвидации монтажно-демонтажных работ. Фактически технологии превращались из цикличных в поточные.

Академик РАЕН А.С. Бурчаков часто такие «криволинейные» технологии отработки запасов шахты сравнивал с сельскохозяйственной технологией вспашки полей, при которой трактор все время должен двигаться по криволинейной траектории, близкой к спирали. Конечно, в то время это были довольно смелые технологические идеи и решения, вызывающие порой критику и недоверие у производственников.

Однако современная нацеленность мировой экономики на активное использование малых автономных киберфизических систем уже сегодня вполне дает основание для использования этих идей в формировании новых практических решений для угольной промышленности.

В настоящее время в этих условиях, вероятно, назрела и реализация идеи скоростного проведения горных выработок за счет применения иных физико-технических методов воздействия на горную породу. В свое время в ИГД им. А.А. Скочинского работала целая лаборатория по электроннолучевому способу проведения горных выработок. В середине 1980-х годов этот способ был 
включен Государственным комитетом по науке и технике СССР в «карту» перспективных технологий, которые должны быть реализованы в начале XXI века.

C позиции настоящего времени такая технология могла бы довольно «естественным» образом вписаться в технологии киберфизических систем. Более того, она могла бы достаточно легко сочетаться с технологией 3D-печати, способной вслед за продвижением электронно-лучевого аппарата «печатать» из устойчивых композитов крепь горных выработок, «идеально» прилегающую к «рельефу» обнаженной поверхности горных выработок.

Отметим также, что работа производственных киберфизических систем, особенно при добыче угля и проведении горных выработок, должна обеспечиваться системой самодиагностики деталей и узлов применяемых машин и агрегатов, позволяющей не только подавать сигналы о необходимости замены или ремонта частей оборудования, но и участвовать в практической реализации этих процессов путем применения специальных киберфизических систем поддержания эксплуатации оборудования и машин.

Вышеприведенные производственно-технологические системы добычи угля, подготовки запасов и проведения горных работ должны поддерживаться функциональной интеграцией IT-систем. Такая интеграция осуществляется на базе специальных датчиков, видеокамер, систем управления производством, направляющих информацию в Центр дистанционного управления и контроля для краткосрочного планирования основных показателей производства. Это позволит напрямую связать работников предприятий на всех уровнях их взаимодействия.

Принимаемые производственные решения должны формироваться на основе использования технологий «Большие данные и аналитика».

Под технологиями «Большие данные» подразумевают работу с информацией огромного объема и разнообразного состава, весьма часто обновляемой и находящейся в разных источниках в целях увеличения эффективности работы, создания новых технологических решений и повышения конкурентоспособности.

Технологии «Большие данные» предназначены для обработки:

- более значительных объемов информации, чем бизнес-аналитика;

- более быстро получаемых и меняющихся сведений;

- реструктурированных данных, способов использования, которые мы только начинаем изучать после того, как смогли наладить их сбор и хранение.

При этом информационные потоки необходимо доставлять и обрабатывать на основе применения «облачных технологий».

Фактически «облачные технологии» - это удобная среда для обработки информации, объединяющая в себе аппаратные средства, программное обеспечение, каналы связи, а также техническую поддержку совершаемых производственных процессов. Работа в «облаках» направлена на снижение расходов и повышение эффективности работы предприятий.

В последнее время с целью интенсификации и одновременно повышения комфортизации монотонного труда в реализацию производственных процессов стали внедрять технологии геймификации, то есть использования игровых подходов для повышения эффективности производ- ственной деятельности персонала. Эти технологии также могут найти значительное применение в технологических процессах горного производства.

Важным направлением работы киберфизических систем в автономных производственных блоках является их энергоснабжение. Автономные производственнотехнологические системы добычи угля должны обеспечиваться автономными источниками энергии. Причем эти источники энергии должны быть альтернативными с точки зрения применяемых в настоящее время традиционных источников энергии. Важной особенностью этого направления является миниатюризация источников энергии, диктуемая размерами и объемами используемых роботизированных систем.

Разведка запасов и планирование горных работ должны быть основаны на пространственно-планировочных решениях, соответствующих отработке автономными производственными блоками, в необходимых случаях обеспечивающих переход внутри блока от «прямолинейной» к «криволинейной» технологии добычи угля роботизированными системами.

Разведка запасов и планирование горных работ, контроль движения фронта горных работ, конечно же, должны осуществляться с использованием современных средств навигации. В необходимых случаях в производственной деятельности для оценки состояния горных работ и мониторинга соблюдения требований промышленной безопасности на разрезах должны применяться промышленные дроны. Последние должны комплексно использоваться в решении различных функциональных задач: мониторинга, транспортирования, информационнокоммуникационного обеспечения [13].

Важное место в процессах разведки и планирования горных работ занимают моделирование и стимуляция, цифровое проектирование. Они основаны на применении 3D-моделей с целью ежедневного управления производством. Данные системы позволяют моделировать месторождение, планировать отработку запасов, анализировать альтернативные варианты планов горных работ и определять их наиболее оптимальный вариант в режиме реального времени.

В процессе отработки запасов киберфизические производственные системы взаимодействуют со средой. При этом «среда» представляет собой действительную реальность, совмещаемую с трехмерной виртуальной реальностью, генерируемой компьютером. Фактически процессы горного производства полностью или частично должны погружаться в эту комбинированную среду.

Вышеприведенная система взаимоувязанных технологических элементов позволяет осуществлять текущее планирование и анализ состояния отработки запасов и ведения горных работ в режиме online.

Важное место в процессах горного производства в перспективном периоде будет занимать переработка угля, в том числе глубокая переработка, основанная на применении нанотехнологий и биотехнологий. На основе этого в «контуре» несырьевого производства могут быть получены новые материалы, используемые в различных секторах экономики. Учитывая возрастающие экологические требования, предъявляемые к горному производству, процессом переработки должны быть охвачены не только добываемый уголь, но и все отходы горного производства [14]. 
В этой связи дополнительное производство продукции может быть получено за счет переработки отходов. Новые материалы, получаемые из угля и отходов от его добычи, могут быть использованы в технологиях 3D-nечатu для получения продукции необходимой формы и качества.

В рамках интеллектуальной производственной системы уголь и продукция его переработки, а также продукция переработки отходов, в соответствии с протоколом и регламентом, должны направляться потребителю. В качестве средств доставки этой продукции может быть использован беспилотный транспорт, работающий в едином пространстве искусственного интеллекта. Такой транспорт может быть составлен из совокупности так называемых «умных» вагонов, «знающих» маршруты своего назначения.

Вся транспортная система должна базироваться на реализации когнитивных транспортных процессов, используемых в подсистемах управления: транспортными путями, транспортными средствами, перевозками угля, грузов и людей, транспортной безопасностью.

Инфраструктура такой системы должна включать: информационную подсистему, телекоммуникационную подсистему, подсистему транспортных сенсоров и транспортных исполнительных устройств [15].

Важное значение в процессах самодиагностики машин и оборудования киберфизических систем, а также замены их износившихся деталей имеет использование грузовых дронов. Грузовые дроны, в зависимости от грузоподъемности, в том числе могут осуществлять, в рамках общей интеллектуальной сети, функции доставки запасных частей к оборудованию и машинам.

На транспортных средствах, используемых в горном производстве, все в большей мере будут использоваться автономные альтернативные источники энергии.

\section{ЗАКЛЮЧЕНИЕ}

Приведенная в настоящей статье систематизация элементов проекта «Индустрия-4.0», конечно же, не является исчерпывающей. Однако она дает представление о масштабах и возможностях интенсификации процессов горного производства в будущих условиях реализации очередной промышленной революции. Приведенные технологические решения могут являться базой для создания своеобразной интеллектуальной технологической платформы угольной промышленности. В отличие от существующих платформ, в рамках ее поддержания должны проводиться постоянные научно-исследовательские работы направленные на оптимизацию сочетания перспективных технологий. Технологическая платформа из набора отдельных технологий должна превратиться в постоянно действующий механизм оптимизации сочетания предлагаемых технологических решений. Такой механизм, в виде постоянно поддерживаемого проекта «Шахта будущего», в конце 1970-х и начале 1980-х годов успешно использовался в угольной промышленности. Его разработчиками были Московский горный институт и ИГД им. А.А. Скочинского. В рамках этого проекта проводилась оптимизация горного производства по многим новым направлениям: от новой механизации и технологий добычи до экономики, безопасности и организационных структур управления. Оптимизировались не отдельные решения, а сочетаемый из них комплекс.
Это давало возможность производственникам увидеть оптимальный облик-эталон горного предприятия и позволяло на практике реализовать лучшие технологические решения. Вероятно, в период развития интеллектуальных технологий назрела необходимость реализовать подобный проект, как постоянно действующую интеллектуальную технологическую платформу развития угольной промышленности.

\section{Список литературы}

1. Плакиткин Ю.А., Плакиткина Л.С. Мировой инновационный проект «Индустрия-4.0» - возможности применения в угольной отрасли России. 2. Что «требует» от угольной отрасли четвертая промышленная революция? //Уголь. 2017. № 11. C. 46-53. doi: 10.18796/0041-5790-2017-11-46-53.

2. Плакиткин Ю.А., Плакиткина Л.С. Мировой инновационный проект «Индустрия-4.0»- возможности применения в угольной отрасли России. 1. Программа «Индустрия-4.0» - новые подходы и решения // Уголь. 2017. № 10. C. 44-50. doi: 10.18796/0041-5790-2017-10-44-50

3. Плакиткин Ю.А., Плакиткина Л.С. Назрел ли второй этап реструктуризации угольной отрасли? // Уголь. 2016. № 6. С.65-68. doi: 10.18796/0041-5790-2016-6-65-68. URL: http://www.ugolinfo.ru/Free/062016.pdf (дата обращения: 15.11.2017).

4. World Intellectual Property Organization (WIPO). Patentscope / 2016. URL: http://www.wipo.int/portal/en/ index.html (дата обращения: 15.11.2017).

5. Плакиткин Ю.А. Прогнозные параметры развития энергетики как крупномасштабной системы глобального уровня / Доклад на X международной конференции «Управление развитием крупномасштабных систем (MLSD'2017)» (Институт проблем управления им. В.А. Трапезникова РАН, 2 октября - 4 октября 2017 г., Москва).

6. Плакиткин Ю.А., Плакиткина Л.С. Глобальный инновационный процесс и его воздействие на ценовые и объемные параметры развития мировой энергетики и черной металлургии // Черная металлургия, (Бюллетень научнотехнической и экономической информации). 2017. № 9. C. 3-11

7. Бернд Хиллер «Индустрия-4.0»-умное производство будущего. Опыт «цифровизации» Германии / Материалы VI Международного Форума «Информационное моделирование для инфраструктурных проектов и развития бизнесов Большой Евразии» (7 июня 2017 г., Москва, Россия).

8. «Machinery that repairs itself». URL: http://www.phys.org. news/2017-09-machinery.html (дата обращения: 15.11.2017).

9. Бенно Бунзе «Industrie-4.0» - умное производство будущего (Государственная Ні Тесh Стратегия 2020, Германия), 27 февраля 2016 г.

10. Plattform «Industrie-4.0» - Startseite. URL: http://www. plattform-i40.de/2017-09 (дата обращения: 15.11.2017).

11. Симонова М.Д. Анализ развития информационной базы экономической глобализации на современном этапе // Вестник МГИМО Университета. 2011. № 2. С. 182-187.

12. Ржевский В.В., Бурчаков А.С. Вскрытие и отработка месторождения или шахтного поля блок-стволами. М.: МГИ, 1984. 54 с.

13. Кутахов В.П., Пляскота С.И. Информационное взаимодействие в крупномасштабных робототехнических авиационных системах / Доклад на X международной конференции «Управление развитием крупномасштабных систем 
(MLSD'2017)» (Институт проблем управления им. В.А. Трапезникова РАН, 2 октября - 4 октября 2017 г., Москва).

14. Умнов В.А. Управление отходами в горной промышленности / Экологические проблемы горного производства. URL: https://cyberleninka.ru/article/v/upravlenieothodami-v-gornoy-promyshlennosti (дата обращения: 15.11.2017).
15. Tsyganov V., Malygin I., Komashinsky V. International Experience and Multimodal Intelligent Transportation System of Russia / Доклад на X международной конференции «Управление развитием крупномасштабных систем (MLSD'2017)» (Институт проблем управления им. В.А. Трапезникова РАН, 2 октября - 4 октября 2017 г., Москва).

INNOVATIONS

UDC 658.589:622.3(100) @ Yu.A. Plakitkin, L.S. Plakitkina, 2018

ISSN 0041-5790 (Print) • ISSN 2412-8333 (Online) • Ugol' - Russian Coal Journal, 2018, № 1, pp. 51-57

Title

THE INDUSTRY-4.0 GLOBAL INNOVATION PROJECT'S POTENTIAL FOR THE COAL INDUSTRY OF RUSSIA. 3. "INDUSTRY-4.0" KEY COMPONENTS ALIGNMENT IN ACCORDANCE WITH BASIC MINING PROCESSES

DOI: http://dx.doi.org/10.18796/0041-5790-2018-1-51-57

\section{Authors}

Plakitkin Yu.A.1, Plakitkina L.S. ${ }^{1}$

${ }^{1}$ ERI RAS, Moscow, 117186, Russian Federation

\section{Authors' Information}

Plakitkin Yu.A., Doctor of Economic Sciences, Professor, RANS Member of RAS, Deputy Director, e-mail: uplak@mail.ru

Plakitkina L.S., PhD (Engineering), Corresponding member of the Russian Academy of Natural Sciences, Head of Center a Research of World and Russia of the Coal Industry, e-mail: luplak@rambler.ru

\section{Abstract}

The article presents the results of the authors' research related to the forecasted innovations evaluation. The link between the innovations and the investments to the global economy sectors is demonstrated. The main breakthrough technologies of the upcoming period are presented, as well as assessment of their impact on production volumes in the fuel and energy sector. The authors focused attention on the systematization of technological solutions, that can be implemented in the Russian coal industry. It is shown that during the upcoming period these solutions can be based on the implementation of the project «Industry-4.0» main aspects, including breakthrough technologies assisting the production cyber physical systems. The authors substantiate the potential possibility of applying the technological solutions developed by Russian scientists in the 1980s. It is demonstrated, that under the new conditions the coal industry technological platforms should be built as an array of optimized technological elements, and not as a set of separate technological solutions. It is established, that such a system existed before, as consistently supported «Mine of the Future» smart project.

\section{Keywords}

Innovations costs, Investment, Breakthrough technologies, Technologica solutions alignment, Technological platforms, Coal industry, Mining processes, "Industry-4.0" project, Artificial intelligence, Cyber physical systems, Production units, Smart systems.

\section{References}

1.Plakitkin Yu.A. \& Plakitkina L.S. Mirovoy innovatsionnyy proekt «Industriya-4.0» vozmozhnosti primeneniya v ugol'noy otrasli Rossii. 2 . Chto «trebuet» ot ugol'noy otrasli chetvertaya promyshlennaya revolyutsiya? [The Industry-4.0 globa innovation project's potential for the coal industry of Russia. 2. What «requires» the fourth industrial revolution from the Russian coal industry?]. Ugol' - Russian Coal Journal, 2017, no. 11, pp. 46-53. doi: 10.18796/0041-5790-2017-11-46-53 2. Plakitkin Yu.A.\& Plakitkina L.S. Mirovoy innovatsionnyy proekt «Industriya-4.0» - vozmozhnosti primeneniya v ugol'noy otrasli Rossii. 1. Programma «Industriya-4.0» - novye podkhody i resheniya [The Industry-4.0 global innovation project's potential for the coal industry of Russia. 1. Industry-4.0 Program - new approaches and solutions]. Ugol' - Russian Coal Journal, 2017 no. 10, pp. 44-50. doi: 10.18796/0041-5790-2017-10-44-50

3. Plakitkin Yu.A. \& Plakitkina L.S. Nazrel li vtoroy etap restrukturizatsii ugol'noy otrasli? [Has the second coal industry restructuring stage become imminent?] Ugol' - Russian Coal Journal, 2016, no. 6, pp. 65-68. doi: 10.18796/00415790-2016-6-65-68. Available at: http://www.ugolinfo.ru/Free/062016.pdf (accessed 15.11.2017).
4. World Intellectual Property Organization (WIPO). Patentscope / 2016. Available at: http://www.wipo.int/portal/en/index.html (accessed 15.11.2017). 5. Plakitkin Yu.A. Prognoznye parametry razvitiya energetiki kak krupnomasshtabnoy sistemy globalnogo urovnya [Forecast of energetics development as global large-scale system]. Report in the X International conference "large-scale systems development management (MLSD'2017)", RAS V.A. Trapeznikov Institute of Control Sciences, 02-04 October 2017, Moscow.

6. Plakitkin Yu.A. \& Plakitkina L.S. Global'nyy innovatsionnyy protsess i ego vozdeystvie na tsenovye i ob'emnye parametry razvitiya mirovoy energetiki i chernoy metallurgii [Global innovation process and its effect on price and volume parameters of the world energy and ferrous metallurgy development]. Chernaya metallurgiya - Ferrous metallurgy (Bulletin of scientific, technical and economic information), 2017, no. 9 (Vol.1413), pp. 3-11.

7. Bernd Hiller «Industriya-4.0» - umnoe proizvodstvo budushchego. Opyt "tsifrovizatsii» Germanii [Industry-4.0 is a smart production of the future. Experience of Germany's"digitalization»]. Documents of the 6th International Forum «Information Modelling for Infrastructure Projects and Business Development of Greater Eurasia», June, 7, 2017, Moscow, Russian Federation. 8. Machinery that repairs itself. Available at: http://www.phys.org.news/ 2017-09-machinery.html (accessed 15.11.2017).

9. Dr. Benno Bunse, «Industrie-4.0» - umnoe proizvodstvo budushchego (Gosudarstvennaya Hi Tech Strategiya 2020, Germaniya) [Industrie-4.0 - Smart Production of the Future (National Hi Tech Strategy 2020, Germany)], February, 27, 2016.

10. Plattform «Industrie-4.0» - Startseite. Available at: http://www. plattform-i40.de/2017-09 (accessed 15.11.2017).

11. Simonova M.D. Analiz razvitiya informatsionnoy bazy ekonomicheskoy globalizatsii na sovremennom etape [Analysis of the current economical globalization information base development]. Vestnik MGIMO UniversitetaMGIMO University Newsletter, 2011, no. 2, pp. 182-187.

12. Rzhevsky V.V. \& Burchakov A.S. Vskrytie i otrabotka mestorozhdeniya ili shakhtnogo polya blok-stvolami [Opening and working of a deposit or a mine field using clusters]. Moscow, MGI Publ., 1984, 54 p.

13. Kutakhov V.P. \& Pliaskota S.I. Informatsionnoe vzaimodeystvie v krupnomasshtabnyh robototekhnicheskih aviatsionnyh sistemah [Information interaction in large-scale robotic aviation systems]. Report in the $X$ International conference "large-scale systems development management (MLSD'2017)", RAS V.A. Trapeznikov Institute of Control Sciences, 02-04 October 2017, Moscow.

14. Umnov V.A. Upravlenie othodami v gornoy promyshlennosti:Ekologicheskie problemy gornogo proizvodstva [Mining wastes management: Mining environmental]. Available at: https://cyberleninka.ru/article/v/upravlenieothodami-v-gornoy-promyshlennosti (accessed 15.11.2017).

15. Tsyganov V., Malygin I. \& Komashinsky V. International experience and multimodal intelligent transportation system of Russia. Report in the $X$ International conference "large-scale systems development management (MLSD'2017)", RAS V.A. Trapeznikov Institute of Control Sciences, 02-04 October 2017, Moscow. 

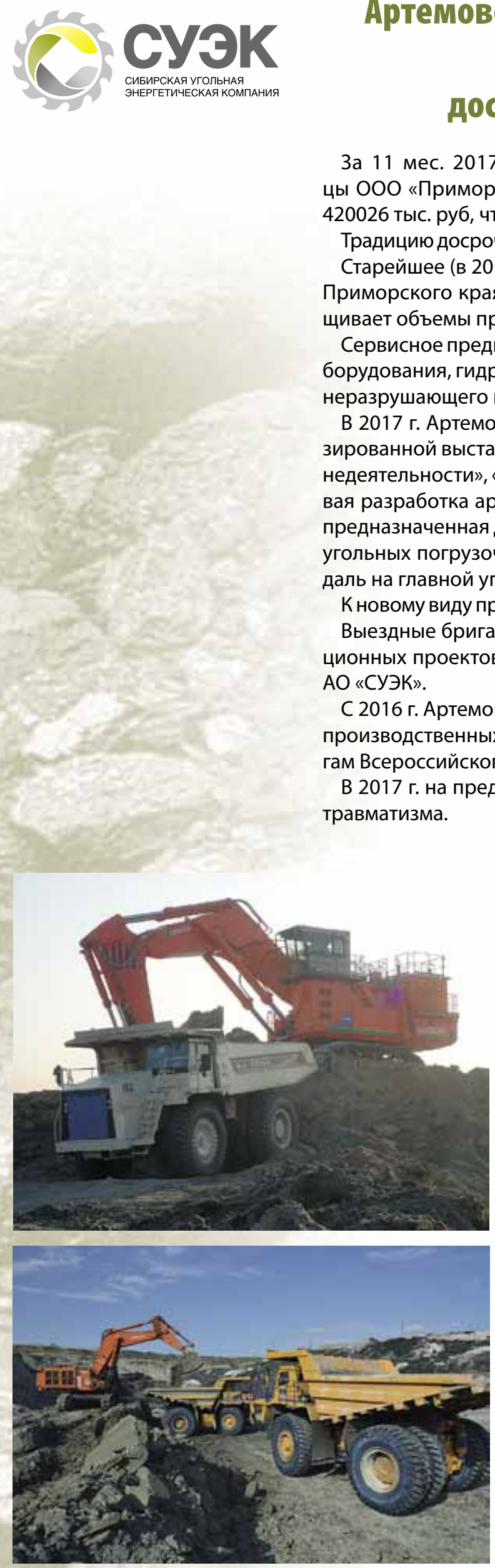

\section{Артемовское Ремонтно-Монтажное Управление 000 «Приморскуголь»}

\section{досрочно выполнило план 2017 года}

За 11 мес. 2017 г. коллектив Артемовского РМУ - производственной единицы ООО «Приморскуголь» обеспечил выполнение годовой программы в объеме 420026 тыс. руб, что составляет 113\% к фактическому уровню 2016 г.

Традицию досрочного выполнения годового плана коллектив поддерживает с 2012 г.

Старейшее (в 2018 г. отметит 105-летие), и вместе с тем современное предприятие Приморского края, Артемовское Ремонтно-Монтажное Управление активно наращивает объемы производства, успешно осваивает выпуск новых видов продукции.

Сервисное предприятие производит ремонт производственной техники, электрооборудования, гидравлики, имеет собственное литейное производство, лабораторию неразрушающего контроля.

В 2017 г. Артемовское РМУ успешно дебютировало на международной специализированной выставке «Уголь России и Майнинг», «Охрана, безопасность труда и жизнедеятельности», «Недра России», состоявшейся в июне 2017 г. в г. Новокузнецке. Новая разработка артемовских специалистов - дробильно-фрезерная машина (ДФМ), предназначенная для дробления смерзшегося угля в условиях низких температур на угольных погрузочно-разгрузочных комплексах портов, завоевала серебряную медаль на главной угольной выставке страны.

К новому виду производства - выпуску ДФМ - Артемовское РМУ приступило в 2017 г.

Выездные бригады Артемовского РМУ принимают участие в реализации инвестиционных проектов на территориях добычных предприятий ООО «Приморскуголь», $\mathrm{AO}$ «СУЭК».

С 2016 г. Артемовское Ремонтно-Монтажное Управление входит в ТОП-10 «Лучших производственных организаций Приморского края в области охраны труда» по итогам Всероссийского конкурса «Успех и безопасность».

В 2017 г. на предприятии не допущены случаи аварийности и производственного травматизма.

\section{В разрезоуправлении «Новошахтинское» состоялся День повышенной добычи угля}

6 декабря 2017 г. в РУ «Новошахтинское» ООО «Приморскуголь» организован День повышенной добычи.

Суточное задание для горняков приморского предприятия СУЭК было установлено в объеме 30 тыс. т. Фактический показатель добычи составил 32,9 тыс. т угля, что превышает обычный плановый показатель добычи в сутки в 3 раза.

День повышенной добычи в целях достижения знаменательной 100-миллионной отметки состоялся на всех предприятиях СУЭК.

Его главными задачами стали: рационализация технологического процесса, повышение производительности труда при безусловном соблюдении правил безопасности, развитие активности и творческой инициативы работников.

В ноябре 2017 г. коллектив РУ «Новошахтинское» отгрузил потребителям рекордное количество угля в объеме 525 тыс.т. Подобный результат установлен впервые в истории разрезоуправления.

На разрезе «Павловский № 2»- основном производственном участке предприятия - годовые программы были выполнены досрочно в объеме 3 млн т по отгрузке (24 ноября) и добыче угля (27 ноября).

В 2017 г. предприятие отметило 35-летие с момента открытия разреза «Павловский № 2». 


\section{Разрез «Камышанский» компании «СУЭК-Кузбасс» досрочно выполнил годовой план добычи 2017 года}

Более чем на месяц раньше календарного срока, в конце ноября коллектив разреза «Камышанский» (Прокопьевский район), входящего в состав Разрезоуправления АО «СУЭК-Кузбасс», выполнил годовой производственный план в объеме 3 млн т угля.

Почетное право добыть 3-миллионную тонну предоставлено бригаде экскаватора Komatsu PC-1250 № 4 под руководством Ивана Федотенко. С новым производственным успехом открытчиков поздравил директор Разрезоуправления «СУЭК-Кузбасс» Александр Кацубин. Лучшим горнякам вручены почетные грамоты.

Отметим, что в 2017 г. на предприятии установлено сразу несколько рекордов месячной производительности российского и мирового уровня по бурению установкой DML-1200 и по добыче горной массы экскаватором Komatsu PC-1250.

Разрез «Камышанский» является одним из лидеров открытой угледобычи в компании «СУЭК-Кузбасс». Благодаря техническому перевооружению за последние

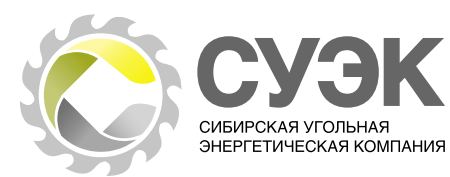

пять лет объемы добычи на предприятии увеличились вдвое.

Одновременно в разрезоуправлении ведется целенаправленная работа по восстановлению нарушенных горными работами земель. За пять лет рекультивировано более 650 га нарушенных земель. В сентябре 2017 г. в рамках акции «Зеленая Россия» сотрудниками предприятия высажено более 70 тыс. молодых сосен.

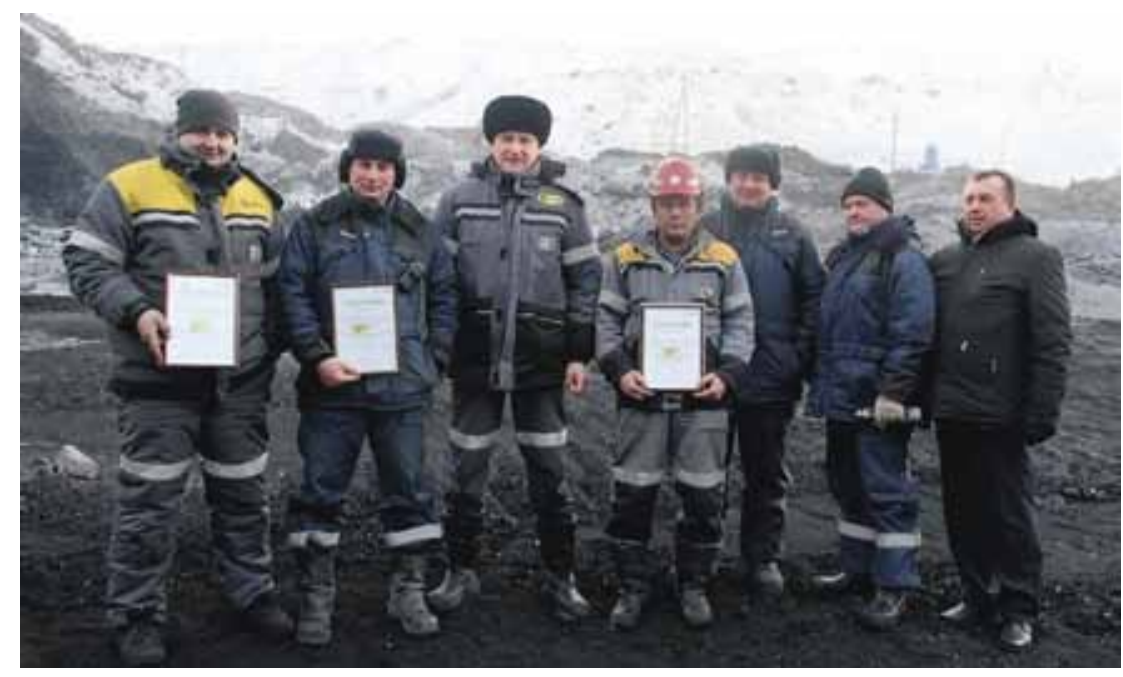

\section{John Deere выиграл тендер на поставку 11 грейдеров для СУЭК}

John Deere и Тимбермаш Байкал стали победителями тендера Сибирской угольной энергетической компании на поставку 11 грейдеров серии 872G. На данный момент уже все машины доставлены заказчику и активно применяются в работах на разрезах в шести регионах России.

Официальный дилер John Deere Тимбермаш Байкал прислушался ко всем пожеланиям заказчика и смог реализовать даже необычные задумки СУЭК, а именно, по специально разработанному эскизу осуществил покраску грейдеров в триколор.

Автогрейдеры серии 872G, переданные крупнейшему производителю угля в России, получили широкое распространение в карьерах и угольных разрезах, поскольку отличаются высокой производительностью, долговечностью и низкими эксплуатационными расходами. Кроме того, модель $872 \mathrm{G}$ сможет обеспечить содержание технологических дорог в угольных разре- зах на протяжении многих смен, поскольку оснащена трансмиссией PowerShift ${ }^{\mathrm{TM}}$ с муфтой и подшипниками повышенной прочности, а также надежным двигателем Tier 2, увеличивающим работоспособность.
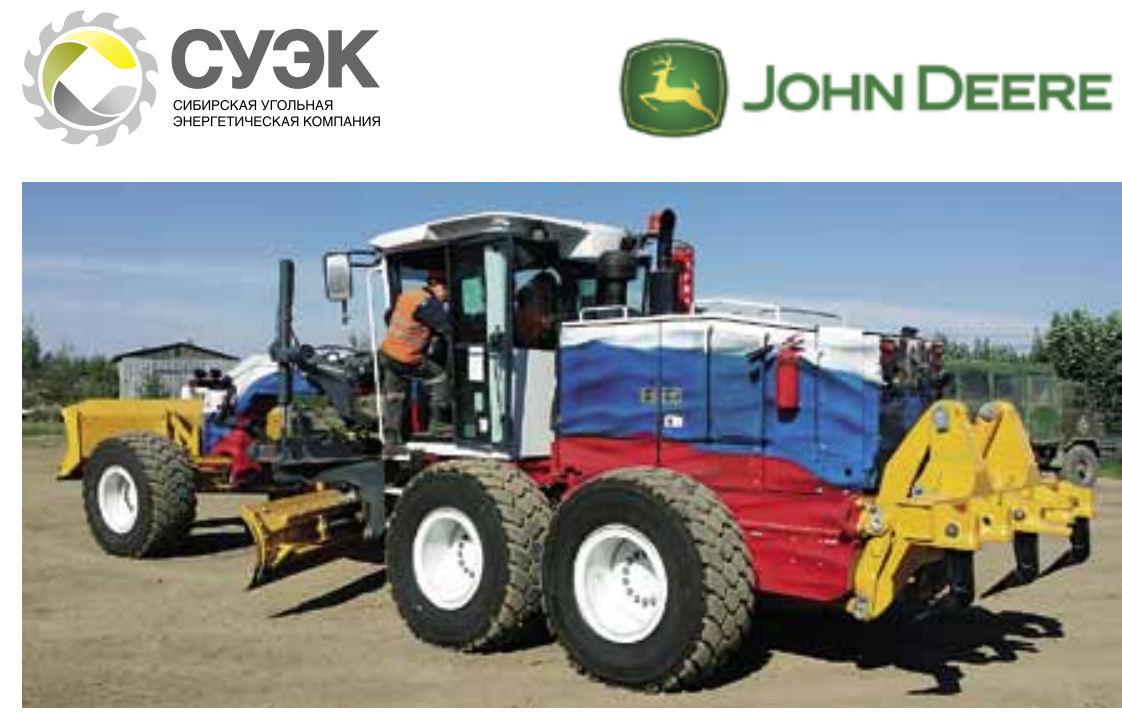


\section{В Приморском крае состоялось торжественное открытие нового разреза «Некковый»}

\begin{abstract}
28 ноября 2017 2. состоялся торжественный ввод в строй нового разреза «Некковый» 000 «Приморскуголь».

В присутствии почетных гостей - глав администраций Михайловского района, поселков Новошахтинский и Липов-
\end{abstract}

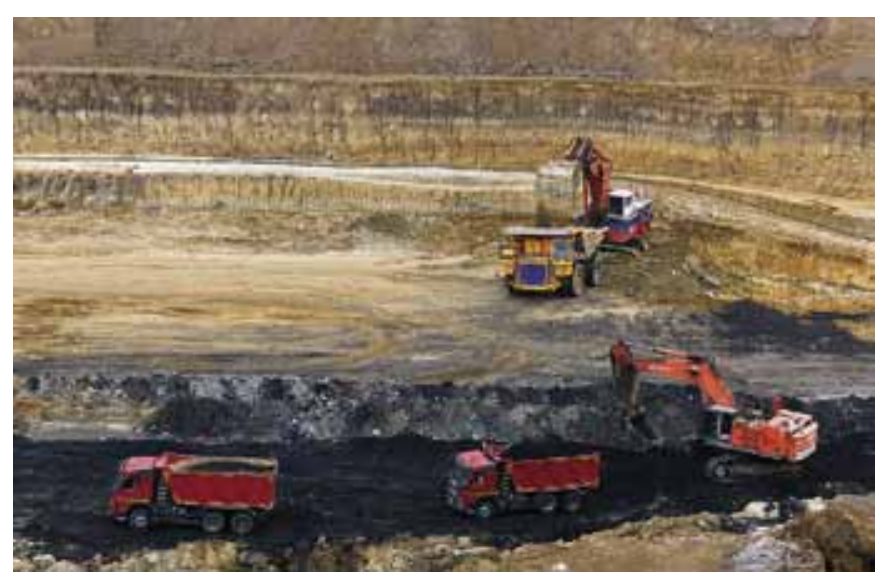

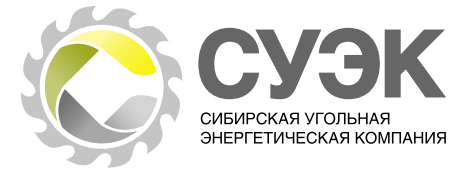

цы, представителей инженерной школы Дальневосточного Федерального Университета, работников приморских предприятий Сибирской угольной энергетической компании, была торжественно добыта первая тонна угля.

Почетное право вывезти первый уголь было предоставлено водителю разреза «Некковый» ООО «Приморскуголь» Андрею Никитенко.

Как отметил генеральный директор ООО «Приморскуголь» Александр Заньков, «основной задачей нового разреза является реализация программы по созданию новых рабочих мест в угольной отрасли края».

«Новое производство угля решает вопросы сочиальной ответственности компании. Разрез даст более 200 рабочих мест горнякам», - подчеркнул глава «Приморскугля».

Проектная мощность разреза «Некковый» составляет 500 тыс. т. Начало строительства - июль 2017 г. Новое производство запущено в короткие сроки. Добываемый уголь - каменный.

\section{Разрезоуправление «Новошахтинское»}

\section{установило рекорд по отгрузке угля за месяц и досрочно выполнило годовой план}

В ноябре 2017 г. коллектив РУ «Новошахтинское» ООО «Приморскуголь» отгрузил потребителям рекордное количество угля в объеме 525 mыс. m. Подобный результат установлен впервые в истории разрезоуправления.

На торжественном собрании трудового коллектива предприятия в честь достижения высокой производственной отметки, были награждены сотрудники участка по отгрузке и переработке угля (начальник Виталий Бычков).

Также, на разрезе «Павловский №2»- основном про-

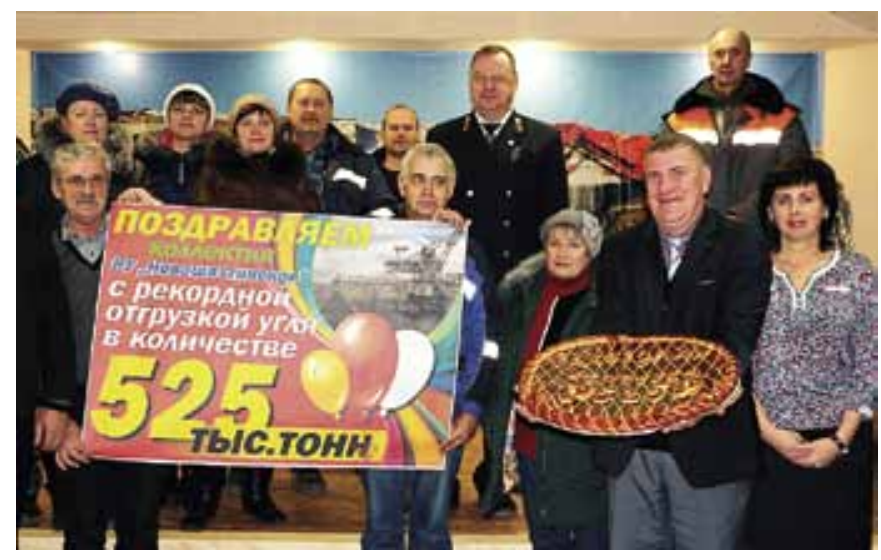

изводственном участке предприятия были выполнены годовые программы в объеме 3 млн т по отгрузке (24 ноября) и добыче угля (27 ноября).

Разрезоуправление «Новошахтинское»- самое крупное предприятие ООО «Приморскуголь» и одно из самых современных и эффективных предприятий региона. На счету коллектива немало трудовых рекордов. В 2011 г. на предприятии впервые была преодолена 4-миллионная отметка годовой добычи и отгрузки угля. В 2015 г. был достигнут уровень квартальной добычи и отгрузки 1,5 млн т. Впервые полумиллионный рубеж отгрузки и добычи был взят в январе 2015 г. В 2016 г. РУ «Новошахтинское» впервые отгрузило уголь на экспорт.

В 2017 г. трудовые рекорды горняков РУ «Новошахтинское» ООО «Приморскуголь» посвящены 70-летию Дня шахтера. Также в 2017 г. предприятие отметило 35-летие с момента открытия разреза «Павловский №2».

РУ «Новошахтинское» ООО «Приморскуголь» осуществляет отработку запасов угля открытым способом на Павловском буроугольном и Липовецком каменноугольном месторождениях. В состав разрезоуправления входят разрезы «Павловский №2» и «Некковый». Основные потребители добываемого угля: энергетика, жилищнокоммунальный сектор. 


\section{І І-Я МЕЖДУНАРОДНАЯ КОНФЕРЕНЦИЯ}

\section{УГОЛЬ СНГ}

15-16 Марта 2018

Беларусь, Минск, Отель «Пекин»
Организатор: МЕТАЛЛ ЭКСПЕРТ

www.metalexpert.com

\section{ТЕМАТИКА И ПОВЕСТКА ДНЯ}

\section{ВНЕШНЯЯ ТОРГОВЛЯ И РЫНКИ СБЫТА}

- Темпы развития премиальных рынков Китая, Японии, Южной Кореи, Тайваня, Индии в 2018 году. Конкурентные позиции поставщиков из России

- Возможности диверсификации импорта коксующегося и энергетического угля в Украине. Прогноз спроса в 2018 году

- Формирование импортных грузопотоков угля в Турции и странах Ближнего Востока в 2018 году

- Экспортный потенциал угольной отрасли Казахстана

- Нефтекокс - растущая альтернатива углю в цементной отрасли. Новые возможности для российских производителей

- Возможности организации стабильных железнодорожных перевозок на экспортных маршрутах в России

- Перспективы расширения перевалки угля в российских портах Балтии в среднесрочной перспективе

- Развитие перевозок угля в Азово-Черноморском бассейне и растущая конкуренция с грузопотоком из портов Балтии в ближневосточном регионе

\section{ЦЕНООБРАЗОВАНИЕ}

- Прогноз цен на коксующийся уголь в России в 2018 году

- Основные ценовые тенденции на рынке энергетического угля: переориентация грузопотоков из Европы в Азию

ПРОИЗВОДСТВО

И ВНУТРЕННЕЕ ПОТРЕБЛЕНИЕ

- Баланс спроса и предложения на рынке коксующегося угля в России в 2018 году

- Прогноз добычи энергетического угля в России: рентабельность производства в условиях ослабленного спроса

- Возможности повышения качества товарного угля в России: перспективы развития обогатительных мощностей

- Формирование новой структуры угольной генерации в Украине за счет перевода антрацитовых ТЭС на высоколетучий уголь

\section{ПРИГЛАШАЮТСЯ}

- Поставщики и потребители угля

- Торговые и сервисные компании

- Транспортные компании

- Аналитики 


\section{Разрез «Черногорский» выполнил годовой план и получил новую технику}

\begin{abstract}
Коллектив разреза «Черногорский» ООО «СУЭК-Хакасия» в третьей декаде ноября 2017 г. выполнил годовой план по добыче угля в объеме 7 млн $m$.
\end{abstract}

Досрочное выполнение плана практически совпало на предприятии с торжественным вводом в эксплуатацию сразу трех единиц новой техники: двух экс-

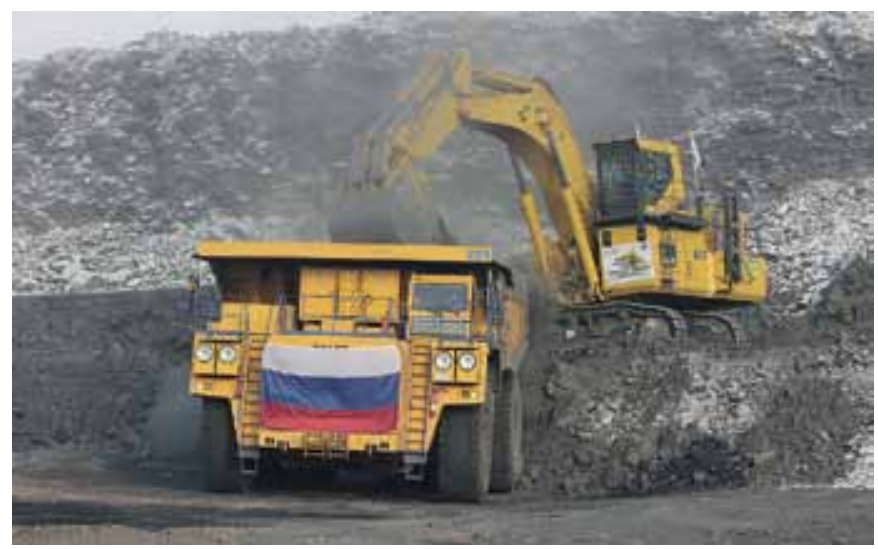

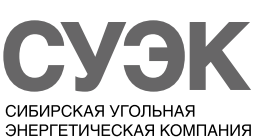

каваторов Komatsu PC-2000 и погрузчика Komatsu WA900; стоимость техники составляет почти 300 млн руб.

«Коллектив разреза «Черногорский» традиционно вносит самый весомый вклад в суммарный результат угледобычи предприятий СУЭК в Республике Хакасия, - говорит генеральный директор ООО «СУЭК-Хакасия» Алексей Килин. - Достойное завершение 2017 года и ввод новой техники - это задел на будущее. В 2018 г. от горняков разреза мы вправе ждать высоких производственных достижений».

В дополнение к трем введенным в эксплуатацию машинам на разрезе «Черногорский» в настоящее время ведется монтаж нового экскаватора Komatsu PC-4000. Умение эффективно эксплуатировать высокопроизводительную технику горняки разреза «Черногорский» «СУЭК-Хакасия» постоянно доказывают высокими достижениями. Только во второй половине 2017 года три экипажа экскаваторов установили мировые рекорды по отгрузке горной массы в автосамосвалы.

\section{Разрез «Апсатский» досрочно выполнил план 2017 года по добыче угля}

Горняки разреза "Аnсатский», входящего в состав Сибирской угольной энергетической компании (АО «СУЭК»), досрочно выполнили план 2017 года по добыче угля в объеме 600 mыс. $m$.
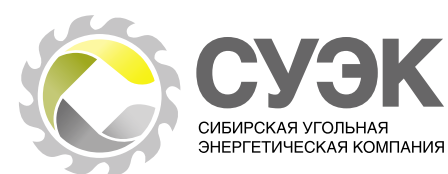

ломатов; водитель автомобиля SCANIA Фердауз Ганеев; машинист буровой установки Flex ROC D60 Алексей Обрубов; начальник участка Владимир Зубко.

По словам работников, досрочное вы-

Утром 3 декабря 2017 г. на территории предприятия состоялся митинг, посвященный досрочному выполнению годового плана. Главный инженер Апсатского разреза Дмитрий Дулин поздравил коллектив со знаменательным событием.

За добросовестный труд, высокий профессионализм и личный вклад в досрочное выполнение годового плана по добыче угля благодарственными письмами отмечены сотрудники разреза. Среди награжденных: машинист погрузочно-доставочной машины САТ 988 Н Алексей Бородин; водитель автомобиля TEREX TR-100 Дмитрий Сa-

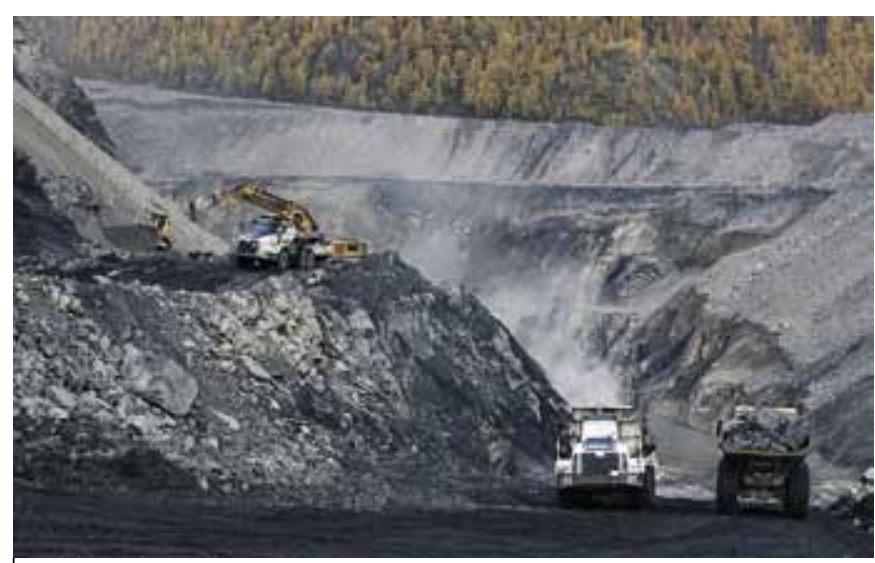
полнение годового плана - это большая трудовая победа, которая стала возможной благодаря сплоченности, трудолюбию, ответственности и профессионализму.

На территории АБК предприятия Дед Мороз и Снегурочка уже зажгли новогоднюю елочку.

Отметим, разрез «Апсатский» - одно из самых молодых угледобывающих предприятий Забайкальского края. Развитию предприятия СУЭК уделяет повышенное внимание, оснащая его самой передовой высокопроизводительной техникой. Недавно разрез «Апсатский» перешагнул отметку в 3 млн т по добыче угля с начала эксплуатации.

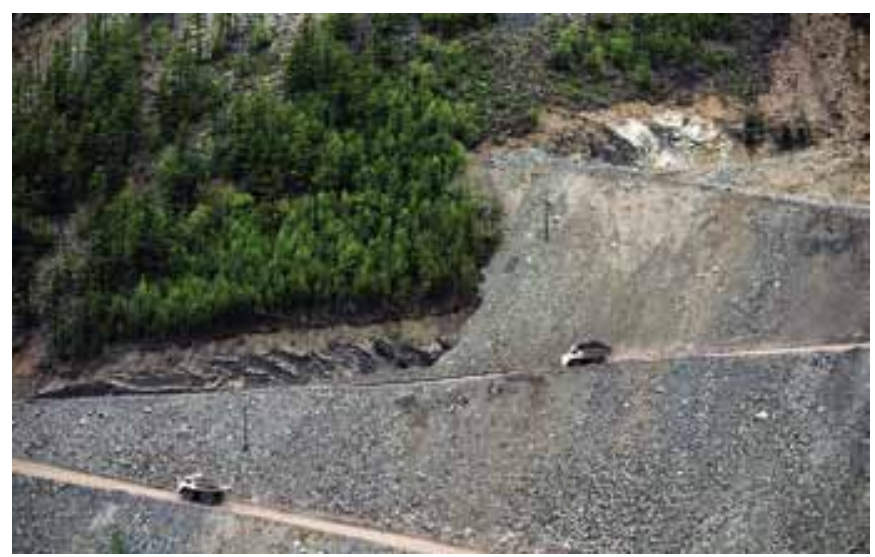




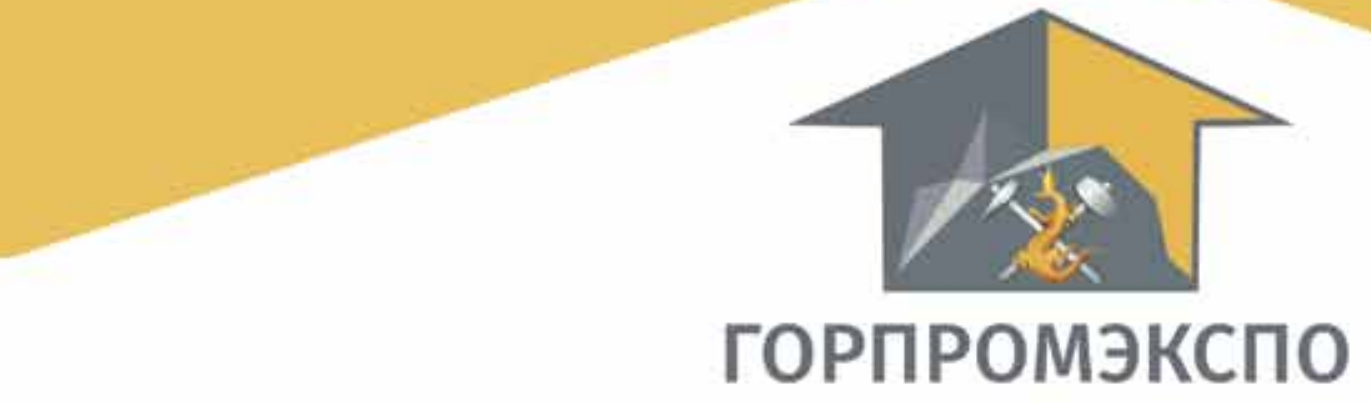

ВЫСТАВКА-ФОРУМ

\section{Организаторы: \\ Министерство промышленности и торговли РФ \\ НП «Горнопромышленники России»}

\section{ПЕРЕДОВЫЕ ДОСТИЖЕНИЯ В ГОРНОЙ ПРОМЫШЛЕННОСТИ РОССИИ И МИРА}

Демонстрация инструментов государственной поддержки российского производителя и совершенствования государственно-частного партнерства, направленных на развитие отраслей отечественного минерально-сырьевого комплекса и продвижение профильных российских экспортеров на международном рынке.

Непосредственный контакт производителей и поставщиков горных машин и оборудования со специалистами горнодобывающих предприятий, горно-обогатительных комбинатов и оптовых торговых компаний.

Презентация достижений фундаментальной и прикладной науки в области горного дела, возможностей развития отечественной горной промышленности на основе диверсификации деятельности предприятий оборонно-промышленного комплекса России.

Проведение Национального горнопромышленного форума, который призван содействовать повышению эффективности и конкурентоспособности отраслей минерально-сырьевого комплекса страны.

Прямое взаимодействие руководителей горного бизнеса и исполнительной власти Российской Федерации.

\section{1-14 апреля 2018}

\section{Москва, «Гостиный двор»}

Москва, ул. Ильинка, 4

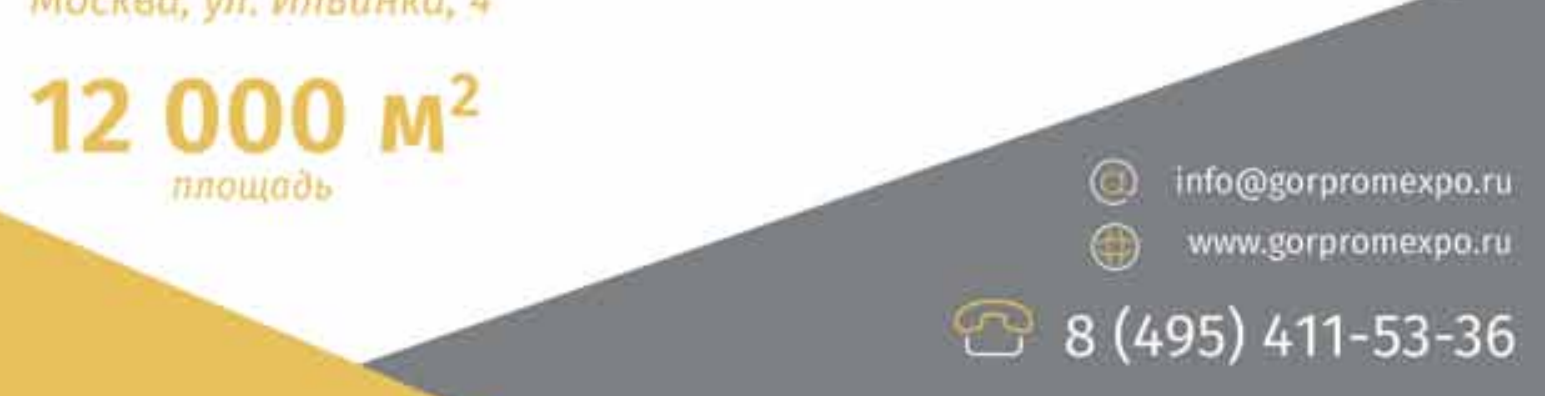




\section{На шахте «Талдинская-Западная - 1» АО «СУЭК-Кузбасс» установлен новый рекорд добычи}

\begin{abstract}
Коллектив шахты «ТалдинскаяЗападная - 1» АО «СУЭК-Кузбасс» 22 декабря 2017 2. перешагнул пятимиллионный рубеж годовой добычи, установив тем самым новый рекорд предприятия.
\end{abstract}

На торжественном митинге директор шахтоуправления «Талдинское-Западное» Михаил Лупий отметил, что такой результат достигнут впервые за всю тридцатилетнюю историю шахты. Рекорд состоялся благодаря удар-

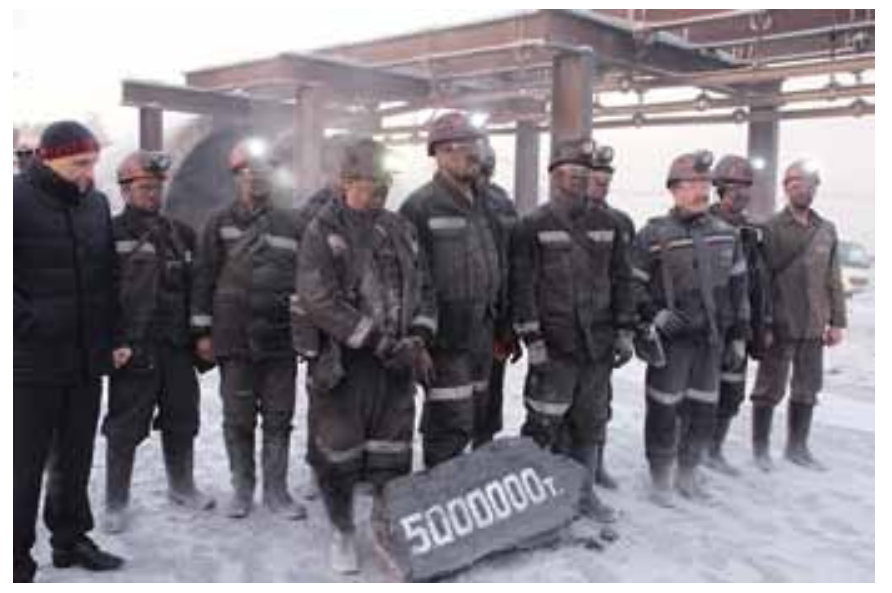

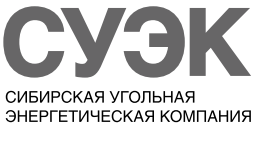

ному труду проходческих участков, механической службы и, конечно, добычников- очистной бригады под руководством Владимира Березовского.

С начала 2017 года этим высокопрофессиональным коллективом выдано нагора более 4,7 млн т угля, что также является рекордным показателем производительности. Напомним, что 15 ноября 2017 г. в Кремле Президент России Владимир Путин вручил бригадиру очистной бригады шахты «ТалдинскаяЗападная - 1» Владимиру Березовскому орден «За заслуги перед Отечеством» IV степени.

По уровню эффективности угледобычи шахта «Талдинская-Западная - 1» прочно входит в число лидеров угольной отрасли. За последние пять лет в переоснащение и развитие предприятия Сибирской угольной энергетической компанией вложено более 8 млрд руб. Значительная часть инвестиций направлена на переход шахты для отработки пласта № 66. В числе реализованных проектов также оснащение электрогидравлической системой управления механизированной крепью фирмы marco, модернизация забойного конвейера и ленточного конвейера. В октябре здесь введены в эксплуатацию инновационные очистные сооружения, стоимость первой очереди которых составила 500 млн руб.

\section{СУЭК - лидер корпоративной благотворительности}

13 декабря 2017 г. в Москве оглашенырезультаты очередного исследования-рэнкинга «Лидеры корпоративной благотворительности»- совместного проекта Форума Доноров, международной аудиторско-консалтинговой сети фирм РшС и газеты «Ведомости».

В ходе церемонии было объявлено, что АО «СУЭК» стало обладателем специального приза «За эффективность управления благотворительными программами», а также заняло призовое место в номинации «Информационная открытость благотворительной деятельности».

Проект «Лидеры корпоративной благотворительности» направлен на поддержку, развитие и продвижение идей корпоративной благотворительности. Целью проекта являются выявление лучших образцов благотворительных программ и распространение информации о корпоративной благотворительности в бизнес-среде и в обществе в целом.

Исследование является одним из крупнейших событий в сфере корпоративной благотворительности в России. Проект включает в себя проведение исследования корпоративной благотворительности по специально разработанной методологии, результатом которого являются рэнкинг компаний и конкурс благотворительных программ компаний. Методология проекта позволяет компаниям не только представить объемы финансирования благотворительных программ, но и продемонстрировать содержательную сторону проектов, их миссию, аудиторию, методику, ожидания и результаты. Проект поддерживают Министерство экономического развития Российской Федерации, Российский союз промышленников и предпринимателей, Ассоциация менеджеров.

$\mathrm{AO}$ «СУЭК» - один из признанных лидеров корпоративной социальной ответственности и благотворительности в стране. В 2016 г. компания вложила в социальные и благотворительные проекты порядка 1 млрд руб. Компания ежегодно реализует порядка 150 проектов в регионах присутствия, направленных на комплексное повышение качества жизни сотрудников предприятий, членов их семей и жителей регионов.

Компания традиционно входит в число лидеров данного исследования. В 2016 г. компания была признана победителем в номинации «Лучшая программа, раскрывающая политику корпоративной благотворительности и принципы социальных инвестиций компании» и заняла второе место в общем рэнкинге. 


\section{СУЭК запустила программу повышения квалификации региональных медицинских работников}

АО «СУЭК» начало реализацию программы «наше здоровье: новые подходы к организации здравоохранения", направленной наповышение квалификации медицинских работников из регионов, в которых работают предприятия СУЭК. Программа реализуется Фондом «СУЭК-РЕГИОНАМ» в сотрудничестве с центральными медицинскими учреждениями Управления делами Президента РФ.

Первыми участниками программы стали 25 специалистов-медиков, работающих в больницах и поликлиниках городов и поселков Сибири и Дальнего Востока, для которых в декабре 2017 г. были организованы два учебных курса повышения квалификации.

Для региональных врачей-педиатров, большинство которых представляют первичное звено оказания первой помощи детям, ФГБУ «Детский медицинский центр» Управления делами Президента РФ организовало цикл научнопрактических семинаров «Актуальные вопросы педиатрии». В их рамках прошли симуляционные тренинги оказания неотложной помощи детям с акцентом на современные стандарты и инновационные технологии в педиатрии.
Для второй группы- региональных терапевтов- на базе ФГБУ «Поликлиника № 3» Управления делами Президента Российской Федерации был проведен образовательный курс «Актуальные вопросы диагностики и лечения внутренних болезней». Учебные семинары курса были посвящены актуальным вопросам гастроэнтерологии, пульмонологии, иммунологии, ревматологии, урологии, нефрологии, гинекологии, кардиологии, клинической фармакологии, онкологии, лучевой диагностики, хирургии, эндокринологии.

Новый проект стал очередным важным звеном комплексной программы СУЭК по восстановлению и укреплению здоровья жителей шахтерских регионов. В программу также входят социально-благотворительный проект по лечению и восстановлению здоровья детей и ветеранов в медицинских учрежденияхУправления делами Президента РФ, социально-предпринимательские проекты в области медицины выпускников ежегодной Школы социального предпринимательства, а также многочисленные региональные проекты по поддержке местного здравоохранения.

\section{В Мурманском морском торговом порту принята}

\section{в эксплуатацию еще одна стационарная система пылеподавления}

В настоящее время на производственной площадке ПАО «ММТП» в круглогодичном режиме функционируют уже 11 установок, эффективно препятствующих пылеобразованию.

Четыре новых генератора снега и водяного тумана производства итальянской компании «EmiControls» установлены на высоких опорных конструкциях на территории грузового района № 1. «Пушки», как еще называют эти установки, изготовлены по специальному заказу портовиков. Они адаптированы для работы в условиях заполярного климата. При положительных значениях температуры окружающего воздуха распыляется мельчайшая водяная взвесь. При наступлении морозной погоды продуктом системы становится снег, который покрывает склады навалочных грузов и технологические проезды, препятствуя ветровой эрозии.

Благодаря имеющимся на каждом генераторе 24 форсункам Quadrijet и 8 нуклеаторам установки распыляют снег и туман в радиусе до 110 м. С учетом ветрового переноса каждая «пушка» обеспечивает осаждение пыли на площади около 14,5 тыс. кв. м, что примерно равняется двум стандартным футбольным полям.

Турбины, предназначенные для рассеивания снега и тумана, имеют внутреннее расположение двигателей, что обеспечивает минимальный уровень вибрации и шумовой нагрузки.
Похожая стационарная система пылеподавления успешно применяется мурманскими портовиками в грузовом районе № 2 с июля 2015 г. Она позволила снизить концентрацию пыли на промышленной площадке и на границе санитарно-защитной зоны порта на 49\%, что подтверждается контрольными измерениями специалистов ведущего в нашей стране НИИ «Атмосфера».

В 2018 г. Мурманский морской торговый порт планирует увеличить мощность стационарной системы пылеподавления в грузовом районе № 1, установив еще 4 аналогичные установки.

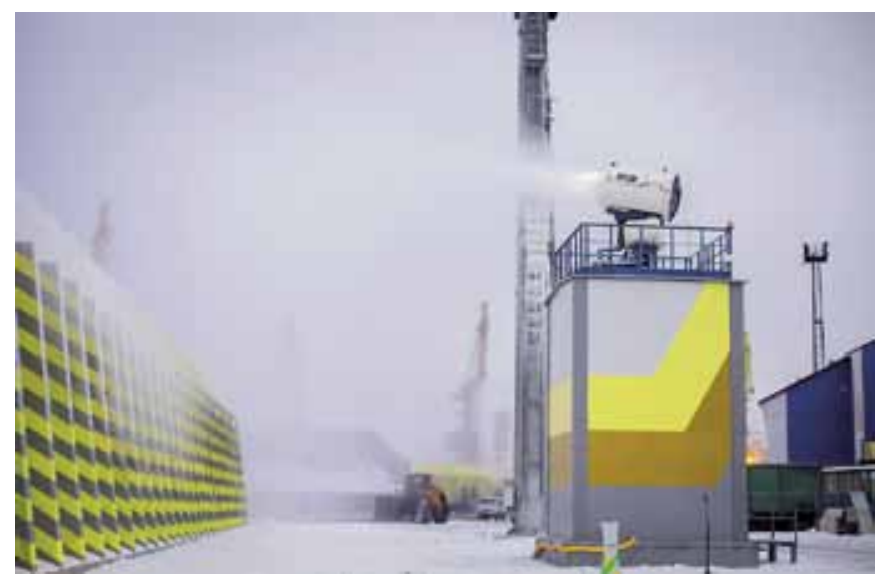



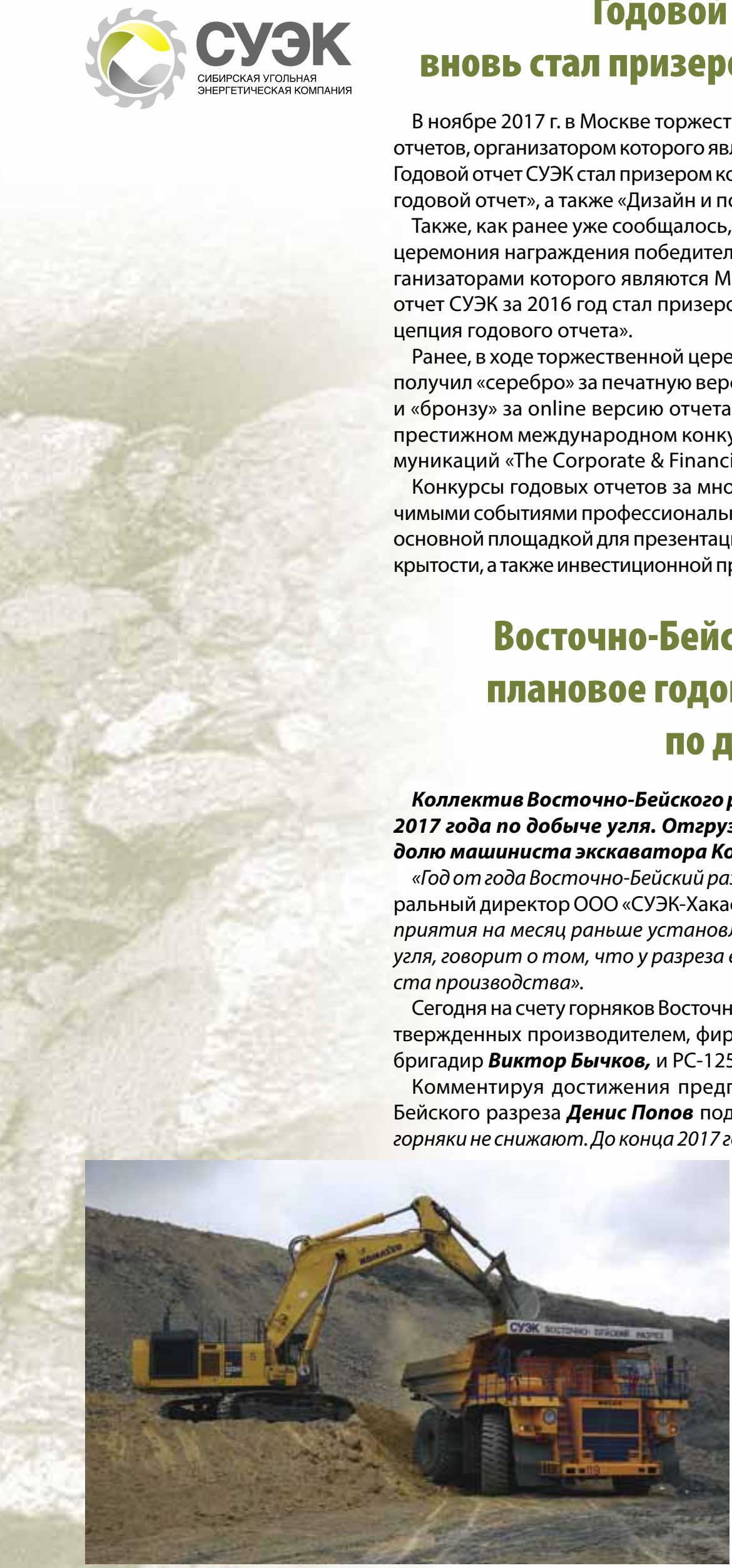
цепция годового отчета». ста производства».

\section{Годовой отчет АО «СУЭК»}

\section{вновь стал призером престижных конкурсов}

В ноябре 2017 г. в Москве торжественно наградили победителей конкурса годовых отчетов, организатором которого является Рейтинговое агентство RAEX («Эксперт РА»). Годовой отчет СУЭК стал призером конкурса в номинациях: «Лучший интегрированный годовой отчет», а также «Дизайн и полиграфия» в категории «Нефинансовый сектор».

Также, как ранее уже сообщалось, в ноябре 2017 г. в Москве состоялась юбилейная церемония награждения победителей XX Ежегодного конкурса годовых отчетов, организаторами которого являются Московская Биржа и медиа-группа «РЦБ». Годовой отчет СУЭК за 2016 год стал призером конкурса в номинации «Лучший дизайн и кон-

Ранее, в ходе торжественной церемонии в Лондоне Годовой отчет СУЭК за 2016 год получил «серебро» за печатную версию «Best printed report» в категории International и «бронзу» за online версию отчета «Best online report» в категории International на престижном международном конкурсе в области корпоративных финансовых коммуникаций «The Corporate \& Financial Awards».

Конкурсы годовых отчетов за многолетнюю историю стали традиционными и значимыми событиями профессионального инвестиционного сообщества. Они являются основной площадкой для презентации годовых отчетов, способствуют повышению открытости, а также инвестиционной привлекательности и деловой репутации компаний.

\section{Восточно-Бейский разрез выполнил плановое годовое задание 2017 года по добыче угля}

Коллектив Восточно-Бейского разреза 29 ноября выполнил плановое задание 2017 года по добыче угля. Отгрузка первых сверхплановых тонн пришлась на долю машиниста экскаватора Komatsu-1250 № 1 Михаила Глушакова.

«Год от года Восточно-Бейский разрез увеличивает объемы добычи, - говорит генеральный директор ООО «СУЭК-Хакасия» Алексей Килин. - И то, что коллектив предприятия на месяи раньше установленного срока выполнил план в объеме 3,2 млн т угля, говорит о том, что у разреза есть значительные резервы для дальнейшего ро-

Сегодня на счету горняков Восточно-Бейского разреза уже 6 мировых рекордов, подтвержденных производителем, фирмой Komatsu. Это экипажи экскаватора PC-3000, бригадир Виктор Бычков, и РС-1250, бригадир Евгений Журавин.

Комментируя достижения предприятия, исполнительный директор ВосточноБейского разреза Денис Попов подчеркнул: «После выполнения плана темп работ горняки не снижают. До кониа 2017 года предприятию поставлена челевая задача достигнуть рубеж по добыче угля 3,5 млн тонн».

Размер инвестиций, освоенный ООО «Восточно-Бейский разрез» с начала 2017 года составил 336 млн руб: введены в эксплуатацию два автосамосвала БелАЗ-75131, автогрейдер JONHDEERE-772G, вспомогательное оборудование. Ввод новой техники и ее освоение позволили увеличить производительность труда до 623 т/мес. на одного работающего, рост к предыдущему периоду составил 4\%.

Инвестиции в строительство очистных сооружений карьерных вод составили 180 млн руб. Руководство и коллектив Восточно-Бейского разреза считают защиту окружающей среды неотделимой частью своей производственной деятельности. 


\section{В Законодательном собрании Красноярского края}

\section{открылась выставка с портретами шахтеров}

\begin{abstract}
В Законодательном собрании Красноярского края открылась выставка «Гордость России - шахтеры!», организованная Сибирской угольной энергетической компанией при поддержке Министерства энергетики Российской Федерации. Экспозичия продолжила череду мероприятий, посвященных 70-летию празднования Дня шахтера, которые СУЭК проводит на протяжении всего 2017 года.
\end{abstract}

Выставка «Гордость России - шахтеры!» является частью большого проекта под названием «Люди угля». Автор снимков - известный индустриальный фотограф Максим Мармур. Его фотографии рассказывают о сегодняшнем дне угольной отрасли, о том, как кардинально она изменилась за последние годы и какую роль играет в становлении промышленной мощи страны. Но все же главные герои экспозиции - это шахтеры.

«Особая каста, особая порода - так назвал горняков Президент России Владимир Путин на торжественном приеме в честь Дня шахтера в Кремле, где впервые состоялся показ этих фоторабот", - отметила, презентуя фотовыставку, заместитель генерального директора АО «СУЭК-Красноярск» по связям и коммуникациям Марина Смирнова. От лица СУЭК она поблагодарила руководи-
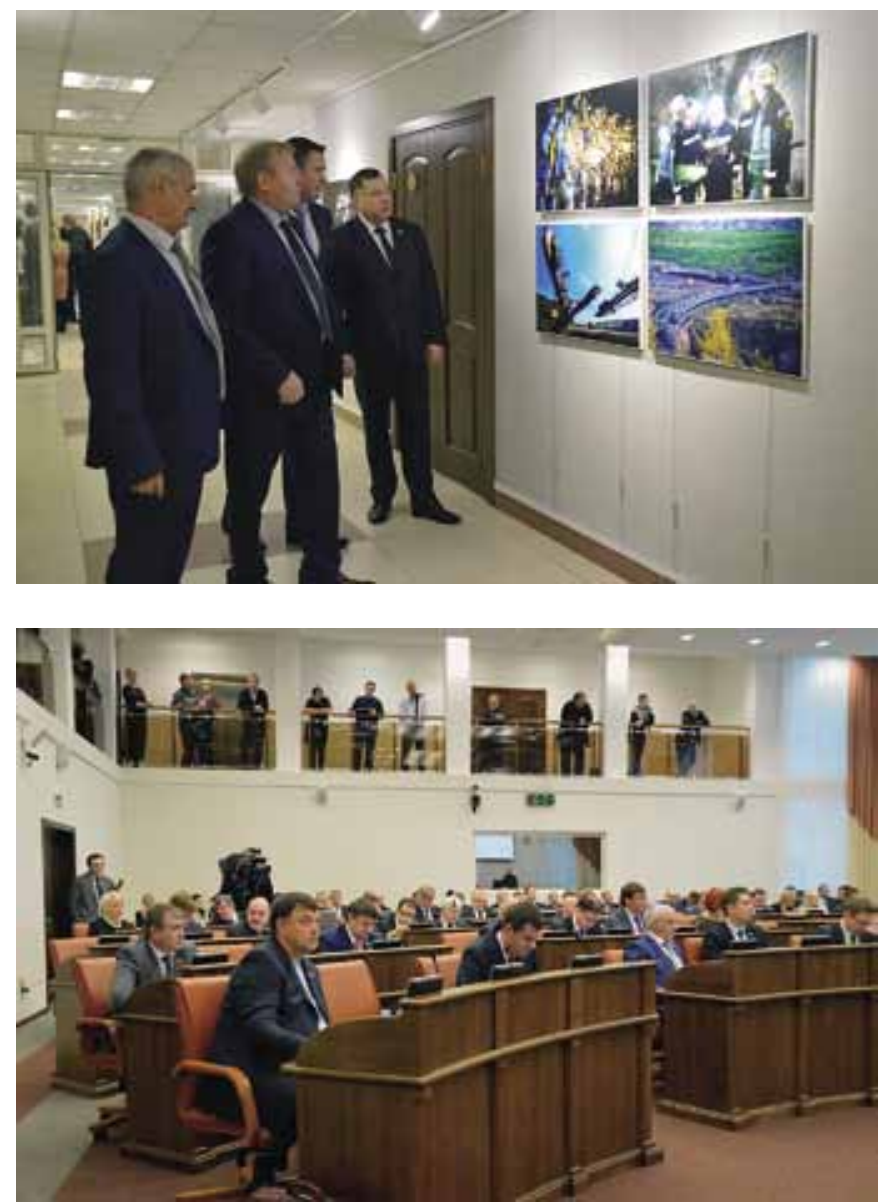

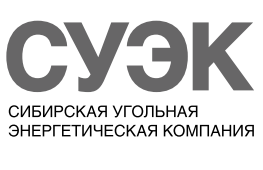

телей Законодательного собрания за содействие в организации выставки и передала в библиотеку краевого парламента книгу «Черное надежное золото. 70 историй о российском угле», подготовленную компанией к юбилею профессионального праздника.

Как подчеркнул присутствовавший на открытии выставки и.о. заместителя председателя Правительства Красноярского края Юрий Лапшин, то, что Красноярск стал первым городом за Уралом, где представлены фотоработы - ранее они экспонировались в Центральном доме художника в Москве и в здании Государственной Думы РФ - неслучайно.

«В нашем регионе добывается каждая десятая тонна российского угля, а по объемам разведанных запасов твердого топлива мы, можно сказать, впереди планеты всей - в крупнейшем Канско-Ачинском угольном бассейне сосредоточено свыше $40 \%$ разведанных запасов страны. Так что профессия шахтера очень важна для сочиального и экономического развития края, - пояснил он. - Неслучайно и то, что выставка развернулась именно в стенах Законодательного собрания: здесь в разные времена кипели жаркие дискуссии о судьбе отрасли. Я рад, что «все сошлось», и теперь это замечательное мероприятие продолжит свое шествие по нашей большой стране».
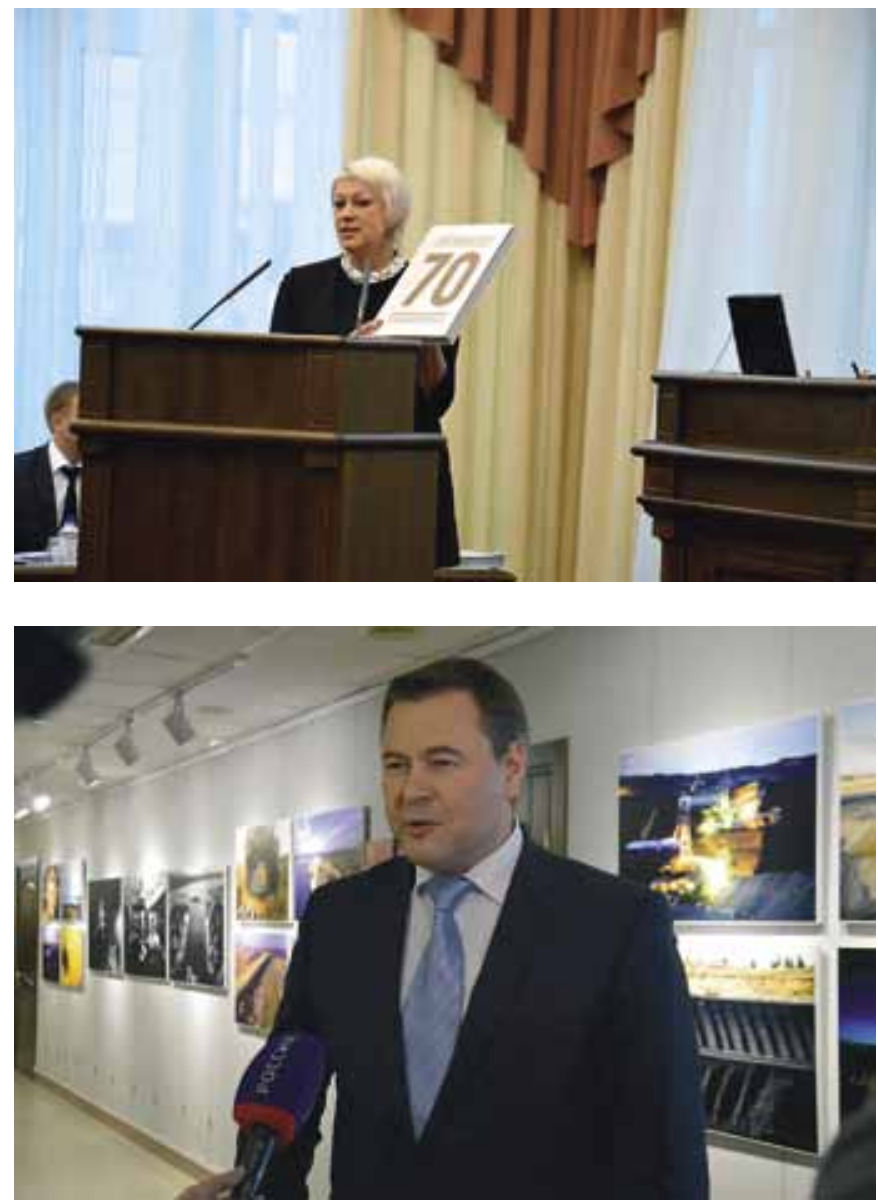


\section{Прогнозирование физико-механических свойств углевмещающих пород на основе данных геофизических исследований скважин и математического аппарата Марковской нелинейной статистики}

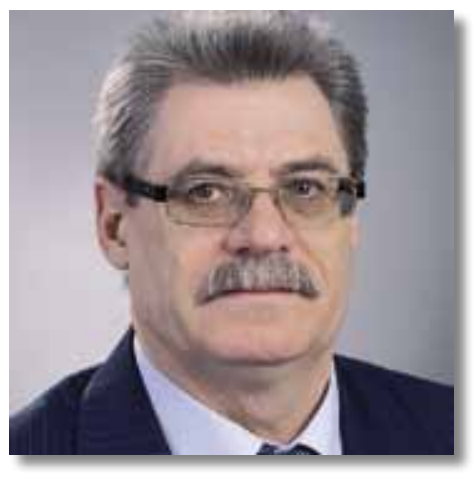

гРИБ Николай Николаевич

Доктор техн. наук, профессор, заместитель директора по научной работе, заведующий кафедрой «Горное дело» Технического института (ф) СВФУ, 678960, г. Нерюнгри, Россия, e-mail: grib@nfygu.ru

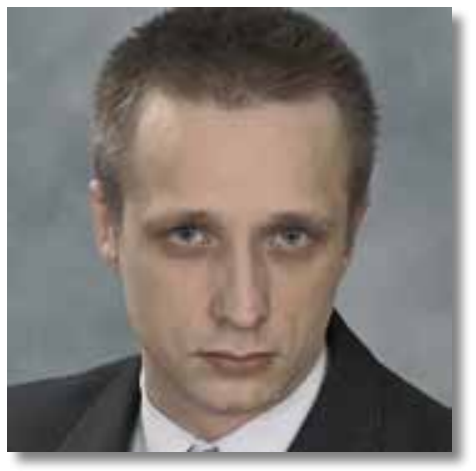

КУЗНЕЦОВ ПавеЛ Юрьевич

Канд. геол.-минер. наук, дочент, дочент кафедры «Горное дело»

Технического института (ф) СВФу, 678960, г. Нерюнгри, Россия, e-mail: kuznetsov.pavel.yu@gmail.com
Статья посвящена прогнозированию физико-механических свойств (ФМС) углевмещающих пород по данным геофизических исследований скважин, проводимых при разведке месторождения и эксплуатации угольных месторождений горным предприятием. Авторами разработан и представлен подход, позволяющий на основе данных геофизических исследований скважин (ГИС) и математического аппарата Марковской нелинейной статистики обоснованно подойти к прогнозу ФМС углевмещающих пород, слагающих месторождение. На основании предложенного подхода для условий Эльгинского каменноугольного месторождения разработаны модельные векторы, позволяющие прогнозировать такие ФМС углевмещающих пород, как: предел прочности на одноосное сжатие, предел прочности на одноосное растяжение, действительная плотность. В статье также проанализированы данные определения ФМС углевмещающихпород, полученные в результате проведения лабораторных исследований, и результаты их прогнозирования по разработанным авторами модельным векторам. Полученные результаты оценки точности и достоверности результатов прогноза свидетельствуют об отсутствии значимых погрешностей прогнозирования, что позволяет применить предложенный авторами подход и модельные векторы прогнозирования ФМС углевмещающих пород в дальнейшем на различных стадиях эксплуатационной разведки Эльгинского месторождения

Ключевые слова: Эльгинское каменноугольное месторождение, физикомеханические свойства (ФМС) углевмещающих пород, предел прочности на одноосное сжатие, предел прочности на одноосное растяжение, действительная плотность, лабораторные исследования, геофизические исследования скважин (ГИС), математический аппарат Марковской нелинейной статистики, модельный вектор, прогнозирование.

\section{ВВЕДЕНИЕ}

Основным источником информации о физико-механических свойствах (ФМС) углевмещающих пород при проектировании и эксплуатации угольных горных предприятий, как правило, являются результаты лабораторных испытаний образцов углевмещающих пород, слагающих месторождения, которые получены на различных стадиях разведки месторождения [1]. При этом стоит отметить, что, как правило, при разведке угольных месторождений, а особенно тех, которые рассчитаны на достаточно длительные временные сроки эксплуатации, прибегают к выделению плановых первоочередных участков отработки месторождения, которые в свою очередь подвергаются наиболее детальному изучению. Такой подход объективно позволяет облегчить проектирование и повысить эффективность введения горного предприятия в эксплуатацию, но при этом ведет и к появлению эффекта неравномерности сети опробования по площади месторождения [1, 2]. Возникновение эффекта неравномерности сети опробования в дальнейшем потребует расширения информативной составляющей базы данных о ФМС углевмещающих пород по менее изученным участкам угольного месторождения за счет проведения до- 
полнительных исследований уже на стадии эксплуатации горного предприятия.

Необходимость расширения информативной составляющей базы данных о ФМС углевмещающих пород на стадии эксплуатации месторождения напрямую связана с обеспечением безопасности и повышением эффективности ведения горных работ. При этом расширение информативной составляющей базы данных, как правило, осуществляется посредством применения достаточно большого спектра широкоизвестных косвенных и прямых методов исследований свойств горных пород [3, 4, 5, 6, 7, 8, 9]. Для наиболее эффективного решения рассматриваемого вопроса на горных предприятиях формируют оптимальный комплекс методов исследования ФМС углевмещающих пород, позволяющий подойти к расширению информативной составляющей базы данных изучаемых свойств наиболее полно, надежно и достоверно, а также обеспечить объективное снижение трудозатрат на его проведение.

Учитывая вышесказанное, с целью повышения эффективности формирования баз данных ФМС углевмещающих пород на стадии эксплуатации месторождения авторами предлагается на основе математического аппарата Марковской нелинейной статистики и данных геофизических исследований скважин (ГИС) разработать способ прогнозирования ФМС углевмещающих пород.

\section{ОБЪЕКТ ИССЛЕДОВАНИЯ}

В качестве объекта исследования принято Эльгинское каменноугольное месторождение Южно-Якутского угольного бассейна. При проведении геологоразведочных работ на рассматриваемом месторождении особое внимание было уделено изучению Северо-Западного участка - участка первоочередной отработки, выделенного на основании решения ГКЗ СССР [10], как объекта для ввода В эксплуатацию горного предприятия [11]. В результате такого решения на Эльгинском каменноугольном месторождении по завершении детальной разведки была сформирована неравномерная сеть опробования (геологоразведочных скважин) с максимальной плотностью на участке первоочередной отработки. Данное обстоятельство позволяет сделать вывод, что принятые и реализуемые на сегодняшний день проектные решения по Эльгинскому каменноугольному месторождению учитывали в себе усредненные значения ФМС углевмещающих пород, которые характеризуют горно-геологические условия именно первоочередного участка отработки.

Данный факт свидетельствует о том, что в дальнейшем при продвижении фронта ведения горных работ и вовлечения в отработку менее изученных участков месторождения возникнет необходимость проведения эксплуатационных геологоразведочных работ, ориентированных на расширение информативной составляющей баз данных ФМС углевмещающих пород.

\section{ИСХОДНЫЕ ДАННЫЕ}

Основными источниками информации при сборе и обработке данных о ФМС углевмещающих пород Эльгинского каменноугольного месторождения являлись отчетные материалы, полученные по результатам детальной разведки и лежащие в основе современных проектных решений порядка эксплуатации Эльгинского месторождения [10], а также материалы предварительного техникоэкономического обоснования [11].

При обработке и анализе отчетных материалов $[10,11]$ авторами установлено, что усредненные показатели ФМС углевмещающих пород Эльгинского месторождения, использованные при проектировании горного предприятия, получены по результатам статистической обработки лабораторных испытаний (5581 проб горных пород). Анализируя количество проб с точки зрения полноты изученности ФМС углевмещающих пород Эльгинского каменноугольного месторождения, можно прийти к выводу, что существующий объем проведенных лабораторных исследований позволяет объективно подойти к решению вопроса расширения информативности базы данных ФМС углевмещающих пород на основе применения математически обоснованных моделей взаимосвязи ФМС углевмещающих пород и результатов ГИС.

В данной статье представлена лишь часть результатов исследования физико-механических углевмещающих пород: действительная плотность $(\rho)$; предел прочности на одноосное сжатие $\left(\sigma_{\text {сж }}\right)$; предел прочности на одноосное растяжение $\left(\sigma_{\mathrm{p}}\right)$.

\section{ПРОГНОЗИРОВАНИЕ ФМС УГЛЕВМЕЩАЮЩИХ ПОРОД}

Основу при разработке способа прогнозирования ФМС углевмещающих пород по данным ГИС, ориентированного на применение математического аппарата Марковской нелинейной статистики (векторное Марковское прогнозирование), составляют функциональные взаимосвязи между ними. Данные принципы, по мнению авторов, наиболее удачно изложены в работах $[12,13]$ и находят свое подтверждение в практических исследованиях, представленных в ряде работ $[14,15,16,17,18]$. А обоснование самой возможности применения векторного Марковского прогнозирования свойств угленосных отложений для условий Южно-Якутского бассейна по данным ГИС достаточно полно рассмотрено в работе [19].

Опираясь на лабораторные результаты опробования ФМС углевмещающих пород и данные ГИС, полученные на стадии детальной разведки Эльгинского месторождения, разработаны следующие векторные модели прогнозирования:

- предел прочности на сжатие $\sigma_{\text {сж }}$ -

$H_{a b s} \Rightarrow H_{\text {otn }} \Rightarrow \Delta I_{\gamma_{j}} \Rightarrow \Delta d_{c_{j}} \Rightarrow K_{\text {kom }}$;

- предел прочности на растяжение $\sigma_{\mathrm{p}}$ -

$H_{a b s} \Rightarrow H_{o t n} \Rightarrow \Delta I_{\gamma_{j}} \Rightarrow \Delta d_{c_{j}} \Rightarrow K_{\text {kom }}$;

действительная плотность $(\rho)-$

$$
K_{\text {kom }} \Rightarrow H_{a b s} \Rightarrow H_{o t n} \Rightarrow \Delta I_{\gamma \gamma p_{j}} \Rightarrow \Delta d_{c_{j}} \Rightarrow \frac{\Delta I_{\gamma \gamma p_{j}}}{\Delta d_{c_{j}}} ;
$$

где: $H_{a b s}$ - абсолютная глубина, м; $H_{\text {otn }}$ - относительная глубина, м; $\Delta I_{\gamma_{j}}, \Delta d_{c_{j}}, \Delta I_{\gamma \gamma p_{j}}$ - нормированные значения естественного гамма-излучения, диаметра скважины, интенсивности рассеянного гамма-излучения, соответственно определяемые по геофизическим диаграммам, относительные единицы; $K_{k o m}$ - цифровой код геологотехнологического горизонта.

В рассматриваемые модельные векторы введена величина - цифровой код геолого-технологического го- 
ризонта $\left(K_{k o m}\right)$, значение которого определяется в зависимости от литолого-петрографического состава пород исследуемого интервала условием формирования углевмещающих пород и их ФМС, характерными для конкретного исследуемого интервала [10]. Для условий Эльгинского каменноугольного месторождения по результатам детальной разведки было выделено семь геолого-технологических горизонтов: $\{1\}$ - выше угольного пласта $\mathrm{Y}_{20} ;\{2\}-\mathrm{Y}_{20}-\mathrm{y}_{16}{ }^{\mathrm{B}} ;\{3\}-\mathrm{Y}_{16}{ }^{\mathrm{B}}-\mathrm{Y}_{14} ;\{4\}-\mathrm{y}_{14}-\mathrm{y}_{8^{\prime}}$; $\{5\}-\mathrm{Y}_{8}-\mathrm{Y}_{5}{ }_{5} ;\{6\}-\mathrm{Y}_{5}{ }^{\mathrm{B}}-\mathrm{H}_{16} ;\{7\}-\mathrm{H}_{16}-\mathrm{H}_{15}$.

Нормирование геофизических данных производилось в соответствии с формулой:

$$
\Delta x=\frac{x_{\text {изм }}-x_{\min }}{x_{\max }-x_{\min }},
$$

где: $\Delta x$ - нормированное значение исследуемого параметра; $x_{\text {изм }}$ - измеренное значение исследуемого параметра; $x_{\max }$ - максимальное значение исследуемого параметра на

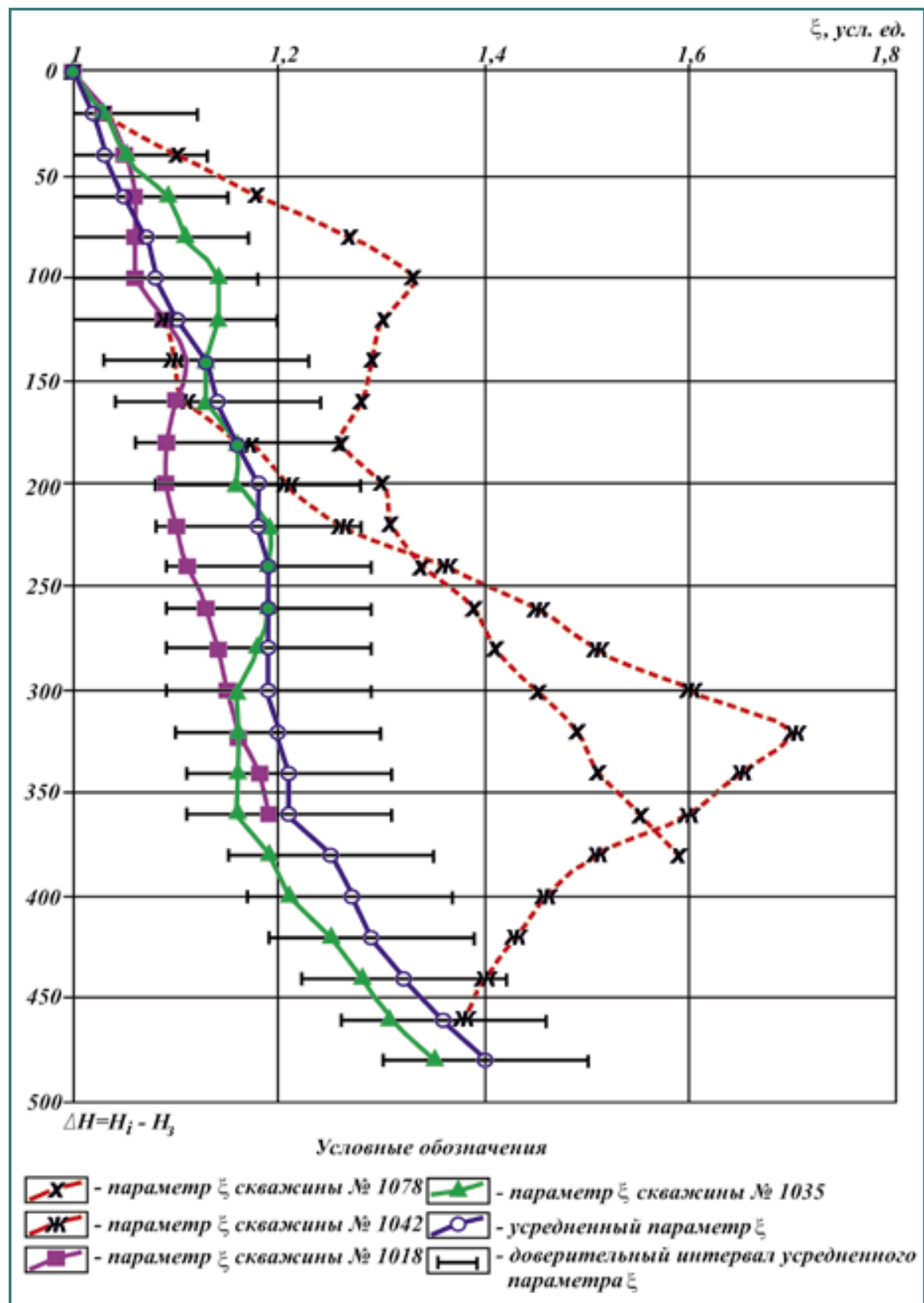

Puc. 1. Палетка разбраковки кавернограмм для условий Эльгинского каменноугольного месторождения

Fig. 1. Caliper logging chart for the Elginsky coal mine всем интервале исследования; $x_{\text {min }}$ - минимальное значение исследуемого параметра на всем интервале исследования.

При интерпретации данных ГИС для создания математической модели прогноза того или иного ФМС углевмещающей породы неизбежно возникает вопрос достоверности и оптимальности описания геофизическими параметрами природного состояния массива углевмещающих пород. Наиболее эффективно этот вопрос, по мнению авторов, можно решить посредством разбраковки геофизических данных по кавернограммам. Оптимальность такого подхода в данной статье обосновывается тем, что во всех предложенных модельных векторах прогноза ФМС углевмещающих пород включены данные по кавернометрии.

Объективность применения результатов кавернометрии для разбраковки данных ГИС обосновывается тем, что они зависят не только от степени разрушаемости пород при нормальных режимах бурения, но и от экстремальных режимов при ликвидации геологических осложнений, возникающих при бурении. Ликвидация аварий при проходке скважины ведет непосредственно к дополнительному увеличению ее диаметра, что находит свое отражение в виде аномалии в данных кавернометрии. Наличие аномалии в данных кавернометрии свидетельствует о том, что все иные геофизические параметры, регистрируемые при ГИС, аналогичным образом будут иметь аномальные значения и некорректно характеризовать природное состояния массива углевмещающих пород.

Методика разбраковки геофизических данных по кавернометрии $[20,21]$ осуществляется на основе построения палетки параметра $\xi$ по всем принятым к исследованию скважинам, которая рассчитывается в соответствии с формулой [20, 21]:

$$
\xi=1+\frac{d_{i}-d_{\text {заб }}}{40},
$$

где: $d_{i}$ и $d_{\text {заб }}$ - диаметры скважины в $i$-той точке наблюдения и на забое соответственно, мм.

Процесс разбраковки по данным кавернометрии по каждой отдельной скважине сводится к оценке соответствия, рассчитанного по глубине скважины параметра $\xi$, доверительному интервалу усредненного параметра $\xi$. Если значения параметра $\xi$, рассчитанного для отдельной скважины, находятся в доверительном интервале усредненного параметра $\xi$, то принимается, что данные ГИС можно использовать для прогнозирования ФМС углевмещающих пород [20, 21].

На рис. 1 представлена палетка разбраковки кавернограмм, содержащая в себе значения усредненного параме- 
тра $\xi$ в зависимости от расстояния до забоя $\Delta H=H_{i}-H_{3}$ (где: $H_{i}$ - глубина в точки наблюдения; $H_{3}$ - глубина забоя скважины) и его доверительный интервал.

При построении палетки были задействованы результаты обработки данных ГИС по 87 скважинам, пробуренным на Эльгинском каменноугольном месторождении. По результатам процедуры разбраковки результатов кавернометрии из дальнейшей обработки были исключены скважины № 1042 и № 1078 (см. рис. 1), правомерность исключения которых подтверждается наличием информации о ликвидации аварий при их бурении в отчетных материалах о разведке месторождения [10]. В конечном итоге непосредственно к созданию модели и прогнозированию ФМС углевмещающих пород по данным ГИС было принято 85 геологоразведочных скважин.

На основе разработанных структур модельных векторов прогноза действительной плотности, пределов прочности на одноосное сжатие и одноосное растяжение углевмещающих пород (формулы 1, 2, 3) были составлены модельные и контрольные выборки прогноза. Модельные и контрольные выборки составлялись на основе наличия и увязывания по глубине геологоразведочной скважины информации о проведенных в ней геофизических исследованиях и данных лабораторного опробования. Таким образом, источником для модельных выборок послужили геологоразведочные скважины: 1288; 1291; 1295; 1457; 1173, а для контрольных - 1158; 1245; 1306; 1547 (рис. 2).

Для удобства ведения расчетов по модельным и контрольным выборкам было применено программное обеспечение Марковских процессов «Векторный прогноз» (версия 2.1.), разработанное А.Г. Черниковым и М.Б. Матушкиным (ВНИИ Геофизика) [19].

Результаты оценки точности и достоверности прогнозируемых показателей ФМС углевмещающих пород Эльгинского месторождения свидетельствуют об отсутствии значимых погрешностей прогнозирования. При этом случайная относительная средняя квадратическая погрешность при прогнозировании не превышает 20\% для прочностных характеристик и 3\% для плотности углевмещающих пород, что удовлетворяет ГОСТам и директивным требованиям [22, 23, 24, 25].

\section{ЗАКЛЮЧЕНИЕ}

Результаты оценки точности и достоверности разработанных модельных векторов для прогноза ФМС углевмещающих пород (предел прочности на одноосное сжатие и растяжение, действительная плотность), представленных в данной статье, позволяют применять их для расширения информативной составляющей базы данных о физико-механических свойствах Эльгинского месторождения. Так, например, только при проведении представленного в данной статье исследования база данных о ФМС углевмещающих пород Эльгинского каменноугольного месторождения была расширена на 85 скважин с интервальной оценкой ФМС углевмещающих пород через 0,2 м по глубине скважин.

Также стоит отметить, что применение горным предприятием разработанных модельных векторов на стадиях эксплуатационной разведки позволит значительно повысить информативность сопровождения производства горных

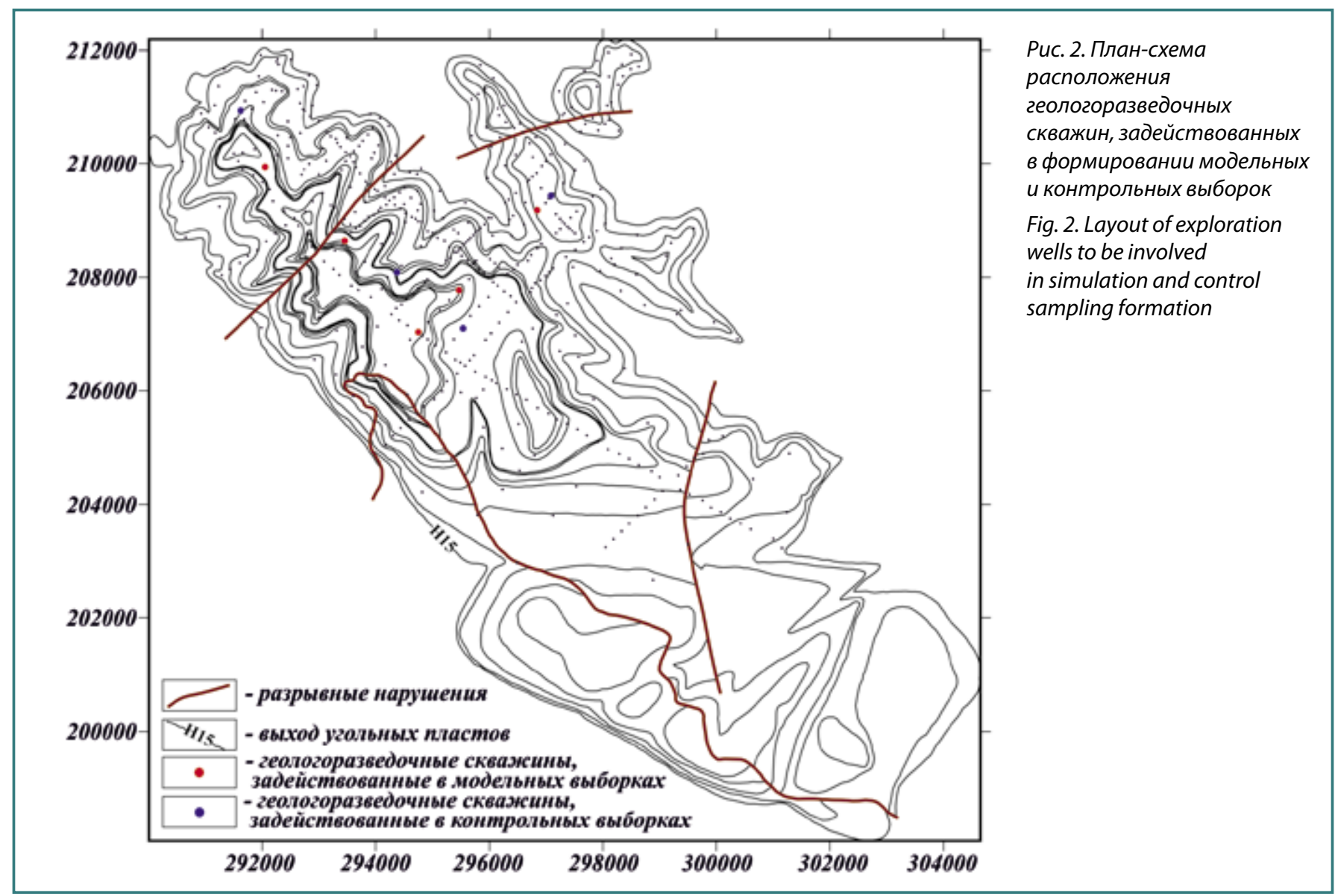


работ и обоснованно производить оперативное управление технологией ведения добычных работ за счет своевременной корректировки документации по планированию и производству горных работ.

\section{Список литературы}

1. Архипов Г.И. Основы недропользования. Хабаровск: Издательство «РИОТИП» краевой типографии, 2008. 356 c.

2. Геотехнологии открытой добычи минерального сырья на месторождениях со сложными горно-геологическими условиями / отв. ред. С.М. Ткач. Рос. акад. наук, Сиб. отд-ние, Ин-т горного дела Севера им. Н.В. Черского. Новосибирск: Академическое издательство «Гео», 2013. 307 с.

3. Kahraman S., Alber M. Predicting the physico-mechanical properties of rocks from electrical impedance spectroscopy measurements / S. Kahraman, M. Alber //International Journal of Rock Mechanics and Mining Sciences. 2006. Vol. 43. issue 4. pp. 543-553. doi: 10.1016/j.jjrmms.2005.09.01.

4. Khandelwal M. Correlating P-wave Velocity with the Physico-Mechanical Properties of Different Rocks / M. Khandelwal // Pure and Applied Geophysics. 2013. Vol. 170. Issue 4. Pp. 507-514. doi: 10.1007/s00024-012-0556-7.

5. Kılıç A., Teymen A. Determination of mechanical properties of rocks using simple methods // Bulletin of Engineering Geology and the Environment. 2008. Vol. 67. Issue 237. doi: 10.1007/s10064-008-0128-3.

6. Yaşar E., Ranjith P., Viete D. An experimental investigation into the drilling and physico-mechanical properties of a rock-like brittle material // Journal of Petroleum Science and Engineering. 2011. Vol. 76. Issue 3-4. pp. 185-193. doi: 10.1016/j.petrol.2011.01.011.

7. Kurtulus C., Sertçelik F., Sertçelik I. Correlating physicomechanical properties of intact rocks with $P$-wave velocity // Acta Geodaetica et Geophysica. 2016. Vol. 51. Issue 3. pp. 571-582. doi: 10.1007/s40328-015-0145-1.

8. Kahraman S., Toraman O., Cayirli S. Predicting the strength and brittleness of rocks from a crushability index // Bulletin of Engineering Geology and the Environment. 2017. Pp. 1-7. doi: 10.1007/s10064-017-1012-9.

9. Prediction of unconfined compressive strength of rocks: A review paper. / E. Momeni, R. Nazir, D. Armaghani, M. Mohd Amin, E Mohamad // Jurnal Teknologi. 2015. Vol. 77. Issue 11. Pp. 43-50. doi: 10.11113/jt.v77.6393.

10. Отчет о результатах детальной разведки СевероЗападного участка Эльгинского каменноугольного месторождения в Токинском угленосном районе ЮжноЯкутского бассейна за 1991-1996 гг.: в 3 т. / ГГГП «Южякутгеология»; исполнители: Н.П. Поляков, М.И. Павлик, Н.Н. Гриб и др. Фонды ГГГП «Южякутгеология», 1996.

11. Эльгинский Угольный Проект. Якутия? Российская Федерация: предварительное ТЭО: отчет (итоговый) в 2 т. / IMC Consulting Engineers Limited. Б. м., 1999.

12. Гречухин В.В. Изучение угольных формаций геофизическими методами. М.: Недра, 1980. 360 с.

13. Гречухин В.В., Воевода Б.И., Климов А.А. Методические указания по геолого-геофизической методике изучения физических свойств пород угольных месторождений. М.: Нефтегеофизика, 1989. 102 с.
14. Прогноз устойчивости углевмещающих пород по геофизическим данным / Н.Н. Гриб, П.Ю. Кузнецов, А.А. Сясько, А.В. Качаев // Фундаментальные исследования. 2013. № 6-2. С. 397-401. URL: http://www. fundamental-research.ru/ru/article/view?id=31521 (дата обращения: 15.12.2017).

15. Изучение физико-механических свойств массива горных пород по данным волнового акустического каротажа / Н.Н. Гриб, А.А. Сясько, А.В. Качаев и др. // Уголь. 2016. № 10. C. 79-84. URL: http://www.ugolinfo.ru/Free/102016.pdf (дата обращения: 15.12.2017).

16. Jullum M., Kolbjornsen O. A Gaussian-based framework for local Bayesian inversion of geophysical data to rock properties // Geophysics. 2016. Vol. 81. Issue 3. Pp. 75-87. doi: 10.1190/geo2015-0314.1.

17. Characterisation of rock ahead and around tunnels and boreholes by use of geophysical and geological methods / G. Rafat, B. Lehmann, A. Toumani, H. Rueter // International Journal of Rock Mechanics and Mining Sciences. 2001. Vol. 38. Issue 6. Pp. 903-908. doi: 10.1016/ S1365-1609(01)00056-9.

18. Gonzatti C., Celestino T., Bortolucci A. Determination of in situ uniaxial compressive strength of coal seams based on geophysical data // Bulletin of Engineering Geology and the Environment. 2009. Vol. 68. Issue 1. Pp. 65-80. doi: 10.1007/ s10064-008-0175-9.

19. Черников А.Г. Рекомендации по обработке и переинтерпретации геолого-геофизических данных на основе автоматизированного геолого-математического моделирования свойств, состава, строения угленосных отложений Южно-Якутского бассейна. М.: Геонаука, 1990.

20. Скоморошко Ю.Н. Оценка устойчивости горных пород в бортах карьеров по результатам геофизических исследований скважин (на примере Эльгинского каменноугольного месторождения): дис. ... канд. техн. наук. Нерюнгри, 2001. 181 с.

21. Кузнецов П.Ю. Оценка пространственной изменчивости свойств массива горных пород для оптимизации сети инженерно-геологических скважин при разведке угольных месторождений (на примере Эльгинского месторождения): дис. ... канд. геол.-минер. наук. Нерюнгри, 2005. 236 c.

22. Инструкция по изучению инженерно-геологических условий месторождений твердых полезных ископаемых при их разведке: Утв. 9. IV. 1973 г. / М-во геологии СССР. Всесоюз. науч.-исслед. ин-т гидрогеологии и инж. геологии «ВСЕГИНГЕО». М.: Недра, 1975. 51 с.

23. Методическое пособие по изучению инженерногеологических условий угольных месторождений, подлежащих разработке открытым способом / М-во угольной пром-сти СССР. Всесоюз. науч.-исслед. ин-т горной геомеханики и маркшейдерского дела. Л.: Недра, 1986. $113 \mathrm{c}$.

24. ГОСТ 21153.2-84. Породы горные. Методы определения прочности при одноосном сжатии. М.: Издательство стандартов, 1984. 10 с.

25. ГОСТ 21153.3-85. Породы горные. Методы определения прочности при одноосном растяжении. М.: Издательство стандартов, 1984. 3 с. 


\section{Title} FORECASTING PHYSICAL AND MECHANICAL PROPERTIES OF COAL-BEARING ROCKS BASED
ON THE WELL LOGGING DATA AND MATHEMATICAL TOOL OF MARKOV NON-LINEAR STATISTICS

DOI: http://dx.doi.org/10.18796/0041-5790-2018-1-68-73

\section{Authors}

Grib N.N. ${ }^{1}$, Kuznetsov P.Yu. ${ }^{1}$

${ }^{1}$ Technical Institute (branch) of M.K. Ammosov North-Eastern Federal University (TI (b) NEFU), Nerungry, 678960, Russian Federation

\section{Authors' Information}

Grib N.N., Doctor of Engineering Sciences, Professor, Deputy Director for Science, Head of the Department of mining, e-mail: grib@nfygu.ru

Kuznetsov P.Yu., PhD (Geological-mineralogical), Associate Professor of the Department of mining, e-mail: kuznetsov.pavel.yu@gmail.com

\section{Abstract}

The paper is about forecasting physical and mechanical properties (PMP) of coalbearing rocks according to the data of geophysical studies of wells conducted during exploration of a deposit and exploitation of coal deposits by a mining enterprise. The authors developed and presented an approach that makes it possible to reasonably forecast the PMP of coal-bearing rocks composing the deposit based on well logging data (WLD) and the mathematical apparatus of the Markov nonlinear statistics. Based on the proposed approach for the conditions of the Elga coal deposit model vectors are developed that can allow predicting such PMP coal-bearing rocks as: tensile strength in uniaxial compression, transtension strength in uniaxial compression, absolute density. The article also analyzes the data on the determination of PMP coal-bearing rocks obtained as a result of laboratory studies and the results of their prediction on the model vectors developed by the authors. The results of the estimation of accuracy and reliability and the obtained results of the forecast indicate the absence of significant forecast errors which makes it possible to apply the approach proposed by the authors and model vectors of PMP prediction of coal-bearing rocks in the future at various stages of operational exploration of the Elga deposit.

Figures:

Fig. 1. Caliper logging chart for the Elginsky coal mine

Fig. 2. Layout of exploration wells to be involved in simulation and control sampling formation

\section{Keywords}

Elga coal deposit, Physical and mechanical properties (PMP) of coal-bearing rocks, Tensile strength in uniaxial compression, Transtension strength in uniaxial compression, Absolute density, Laboratory study, Well logging data (WLD), Mathematical tool of Markov nonlinear statistics, Model vector, Forecasting.

\section{References}

1. Arkhipov G.I. Osnovy nedropolzovaniya [Subsurface resources use basis]. Khabarovsk, "RIOTIP" Publ., at Territorial Printing House, 2008, 356 p.

2. Geotekhnologiiotkrytoy dobychimineralnogo syrya na mestorozhdeniyah so sloz hnymi gorno-geologicheskimi usloviyami [Geotechnologies of surface mining in the fields with complicated mining and geological conditions]. Publishing Editor S.M. Tkach, Russian Academy of Science, Siberial Branch, Chersky Institute of Mining of the North, Novosibirsk, "Geo" Academic Publ., 2013, 307 p.

3. Kahraman S., Alber M. Predicting the physico-mechanical properties of rocks from electrical impedance spectroscopy measurements. International Journal of Rock Mechanics and Mining Sciences, 2006, Vol. 43, issue 4, pp. 543-553. doi: 10.1016/j.jijmms.2005.09.01.

4. Khandelwal M. Correlating P-wave Velocity with the Physico-Mechanical Properties of Different Rocks. Pure and Applied Geophysics, 2013, Vol. 170, issue 4 pp. 507-514. doi: 10.1007/s00024-012-0556-7.

5. Kılıç A. \& Teymen A. Determination of mechanical properties of rocks using simple methods. Bulletin of Engineering Geology and the Environment, 2008, Vol.67, issue 237. doi: 10.1007/s10064-008-0128-3.

6. Yaşar E., Ranjith P. \& Viete D. An experimental investigation into the drilling and physico-mechanical properties of a rock-like brittle material. Journal of Petroleum Science and Engineering, 2011, Vol. 76, issue 3-4, pp. 185-193. doi: 10.1016/j.petrol.2011.01.011.

7. Kurtulus C., Sertçelik F. \& Sertçelik I. Correlating physico-mechanical properties of intact rocks with P-wave velocity. Acta Geodaetica et Geophysica, 2016, Vol. 51, issue 3, pp. 571-582. doi: 10.1007/s40328-015-0145-1.

8. Kahraman S., Toraman O. \& Cayirli S. Predicting the strength and brittleness of rocks from a crushability index. Bulletin of Engineering Geology and the Environment, 2017, pp. 1-7. doi: 10.1007/s10064-017-1012-9.

9. Momeni E., Nazir R., Armaghani D., Mohd Amin M., Mohamad E. Prediction of unconfined compressive strength of rocks: A review paper. Jurnal Teknologi, 2015, Vol. 77, issue 11, pp. 43-50. doi: 10.11113/jt.v77.6393.

10. Polyakov N.P., Pavlik M.I., Grib N.N. et al. Otchet o rezultatah detalnoy razvedki Severo-Zapadnogo uchastka Elginskogo kamennougolnogo mestorozhdeniya $v$ Tokinskom uglenosnom rayone Yuzhno-Yakutskogo basseyna za 1991-1996 gg: $v 3$ tomah [Detailed survey report on the Elginsky coal field north-western area in Tokinsky coal bearing region of the South-Yakutia basin over 1991-1996: 3 volumes]. GGGP"Yuzhyakutgeologiya funds, 1996

11. Elginskiy Ugolnyy Proekt Yakutiya Rossiyskaya Federatsiyapredvaritelnoe TEOotchet itogovyy: 2 tomah [Elginsky Coal Project. Yakutia, Russian Federation: pre-feasibility study; report (final), in 2 volumes]. IMC Consulting Engineers Limited, 1999.

12. Grechukhin V.V. Izuchenie ugolnyh formatsiy geofizicheskimi metodami [Coal formations study by geophysical methods]. Moscow, Nedra Publ., 1980, 360 p. 13. Grechukhin V.V., Voyevoda B.I., Klimov A.A. Metodicheskie ukazaniya po geologo-geofizicheskoy metodike izucheniya fizicheskih svoystv porod ugolnyh mestorozhdeniy [Methodological guidelines for coal fields rock physical properties study]. Moscow, Neftegeofizika Publ., 1989, 102 p.

14. Grib N.N., Kuznetsov P.Yu., Siasko A.A., Kachaev A.V. Prognoz ustoychivost uglevmeshchayushchih porod po geofizicheskim dannym [Prediction of coal bearing rock stability based on geophysical data]. Fundamentalnye issledovaniya-Fundamental Research, 2013, No. 6-2, pp. 397-401. Available at: http://www. fundamental-research.ru/ru/article/view?id=31521 (accessed 15.12.2017).

15. Grib N.N., Siasko A.A., Kachaev A.V. et al. Izuchenie fiziko-mekhanicheskih svoystv massiva gornyh porod po dannym volnovogo akusticheskogo karotazha [Physical and mechanic features of the rock mass under the wave acoustic logging data]. Ugol' - Russian Coal Journal, 2016, No. 10, pp. 79-84. Available at: http:// www.ugolinfo.ru/Free/102016.pdf (accessed: 15.12.2017).

16. Jullum M., Kolbjornsen O. A Gaussian-based framework for local Bayesian inversion of geophysical data to rock properties. Geophysics, 2016, Vol. 81, issue 3, pp. 75-87. doi: 10.1190/geo2015-0314.1.

17. Rafat G., Lehmann B., Toumani A. \& Rueter H. Characterisation of rock ahead and around tunnels and boreholes by use of geophysical and geological methods. International Journal of Rock Mechanics and Mining Sciences, 2001, Vol. 38, issue 6, pp. 903-908. doi: 10.1016/S1365-1609(01)00056-9.

18. Gonzatti C., CelestinoT. \& Bortolucci A. Determination of in situ uniaxial compressive strength of coal seams based on geophysical data. Bulletin of Engineering Geology and the Environment, 2009, Vol. 68, issue 1, pp. 65-80. doi: 10.1007/ s10064-008-0175-9.

19. Chernikov A.G. Rekomendatsii po obrabotke i pereinterpretatsii geologo-geofizicheskih danny ha osnove avtomatizirovannogo geologo-matematicheskogo modelirovaniya svoystvsostavastroeniya uglenosnyh otlozheniy Yuzhno-Yakutskogo basseyna [Recommendation on geologic-geophysical data processing and reinterpretation based on computer-aided geologic-mathematical modelling of the South-Yakutia basin coal bearing deposits properties, composition and structure]. Moscow, Geonauka Publ., 1990.

20. Skomoroshko Yu.N. Otsenka ustoychivosti gornyh porod v bortah karerov po rezultatam geofizicheskih issledovaniy skvazhin (na primere Elginskogo kamennougolnogo mestorozhdeniya). Diss. kand. tekhn. nauk [Open pit rock stability estimation based on well bores geophysical studies (with reference to the Elginsky coal basin). PhD (Engineering) diss.]. Neryungri, 2001, 181 p.

21. Kuznetsov P.Yu. Otsenka prostranstvennoyizmenchivostisvoystvmassiva gornyh porod dlya optimizatsii seti inzhenerno-geologicheskih skvazhin pri razvedke ugolnyh mestorozhdeniyna primere Elginskogo mestorozhdeniya. Diss. kand. geol.-miner. nauk [Rock mass properties variability assessment for engineering geological boreholes during coal fields exploration (with reference to the Elginsky coal basin). PhD (Engineering) diss.]. Neryungri, 2005, 236 p.

22. Instruktsiya po izucheniyu inzhenerno-geologicheskih usloviy mestorozhdeniy tverdyh poleznyh iskopaemyh pri ih razvedke. Utv. 9.IV.1973 g. [Regulation for engineering and geologic conditions study during solid mineral resources deposits exploration. Approved on 9.IV.1973]. Ministry of Geology of the USSR. All-Union Scientific and Research Institute of Hydrogeology and Engineering Geology "VSEGINGEO". Moscow, Nedra Publ., 1975, 51 p.

23. Metodicheskoeposobiepo izucheniyu inzhenerno-geologicheskih usloviyugolnyh mestorozhdeniy podlezhashchih razrabotke otkrytym sposobom [Methodological guideline for engineering-geologic conditions study for coal deposits open mining]. Ministry of Coal Industry of the USSR. All-Union Scientific and Research Institute of Mining Geomechanics and Survey. Leningrad, Nedra Publ., 1986, 113 p.

24. GOST 21153.2-84. Porody gornye Metody opredeleniya prochnosti pri odnoosnom szhatii [Rocks. Methods for determination of uniaxial compression strength]. Moscow, Izdatelstvo standartov Publ., 1984, 10 p.

25. GOST 21153.3-85. Porody gornye Metody opredeleniya prochnosti pri odnoosnom rastyazhenii [Rocks. Methods for determination of uniaxial tensile strength] Moscow, Izdatelstvo standartov Publ., 1984. 3 p. 


\section{Технология очистки отходящих газов ТЭС от серы: регенерация карбонатно-сульфатного расплава монооксидом углерода}

DOI: http://dx.doi.org/10.18796/0041-5790-2018-1-74-80

\author{
ДОСМУХАМЕДОВ Нурлан Калиевич \\ Канд. техн. наук, профессор, \\ ассочиированный профессор \\ Казахского национального исследовательского \\ технического университета им. К.И. Сатпаева, \\ 050013, г. Алматы, Казахстан, \\ e-mail:nurdos@bk.ru
}

\section{ЖОЛДАСБАЙ Ержан Есенбайулы}

Научный сотрудник

Казахского национального исследовательского технического университета им. К.И. Сатпаева, 050013, г. Алматы, Казахстан, e-mail:nurdos@bk.ru

\section{КАПЛАН Валерий Аронович}

Канд. техн. наук, научный консультант Научного института имени Вейчмана, 37270, г. Ришон-ле-Цион, Израиль. тел.:+7 (972) 542311431

Отсутствие надежной системы очистки дымовых газов и использование старых методов улавливания $\mathrm{SO}_{2}$ и других вредных загрязнителей атмосферы привели квозрастанию их концентраций в выбросах выше предельно допустимых норм. Загрязнение воздуха диоксидом серы стало одной из наиболее серьезных проблем, требующих безотлагательного решения. К одному из перспективных решений глубокой очистки отходящих газов ТЭС от сернистого ангидрида относится технология, основанная на поглощении SO, расплавленной смесью карбонатов щелочных металлов. Внедрение технологии сдерживается ввиду отсутствия надежного способа регенерации сульфатно-карбонатного расплава.

В настоящей работе приведены результаты укрупненнолабораторных испытаний процесса химической регенерации карбонатно-сульфатного расплава путем восстановления монооксидом углерода. Проведены исследования по восстановлению карбонатно-сульфатного расплава состава, \%: $\mathrm{Na}_{2} \mathrm{CO}_{3}-30,91 ; \mathrm{Li}_{2} \mathrm{CO}_{3}-51,02 ; \mathrm{K}_{2} \mathrm{SO}_{4}$ - 18,07 монооксидом углерода при температуре $550^{\circ} \mathrm{C}$. Установлено, что при продолжительности продувки расплава монооксидом углерода в течение 60 мин. достигается максимальное удаление серы из расплава в форме COS. Извлечение серы из расплава составляет более $99 \%$.
На основании экспериментальных результатов рассчитаны кинетические параметры процесса химической регенерации карбонатно-сульфатного расплава путем восстановления монооксидом углерода. Рассчитано значение энергии активации $E=10,96$ кДж/моль и определен порядок реакции $n=2$. Показано, что процесс химической регенерации карбонатно-сульфатного расплава описывается сложным механизмом: взаимодействием сульфатов щелочных металлов с СО и протеканием обменных реакций между карбонатами щелочных металлов с их сульфатами.

Полученные результаты использованы при отработке технологии очистки отходящих газов на котельной установке К-19 АО «Энергоорталык-3», включающей проведение балансовых испытаний процесса сжигания угля, химической абсорбции отходящих газов карбонатным расплавом щелочных металлов и регенерации карбонатно-сульфатного расплава путем восстановления монооксидом углерода. Ключевые слова:уголь, сернистый ангидрид, сульфатнокарбонатный расплав, монооксидуглерода, регенерация, COS-газ.

\section{ВВЕДЕНИЕ}

В настоящее время промышленные выбросы предприятий Казахстана в атмосферу составляют порядка трех миллионов тонн в год, из которых 85\% приходятся на 43 крупные тепловые угольные электростанции и металлургические производства. Каждым отдельно взятым предприятием цветной металлургии в атмосферу ежегодно выбрасывается более 100 тыс. т сернистого ангидрида. Большинство зон высокого загрязнения атмосферного воздуха совпадает с местами концентрированного расселения людей. Именно поэтому загрязнение воздуха диоксидами серы является одной из наиболее серьезных проблем в масштабе республики, требующих незамедлительного решения. Длительное отставание с сооружением в Казахстане опытно-промышленных и промышленных высокоэффективных технологий очистки дымовых газов от сернистого ангидрида усложняет и без того тяжелое положение с улавливанием серы в энергетике.

Для очистки дымовых газов от сернистого ангидрида в мировой практике широкое распространение получили «мокрые» абсорбционные способы, использующие в качестве сорбента известь или известняк. Из всего количества действующих сегодня в мире установок для улавливания серы около 90\% составляют установки, использую- 
щие мокрые абсорбционные способы. К примеру, с применением извести в США работают около 35\% установок очистки газов от серы, в Германии - 20\%, в Японии - 11\% [1]. Однако известные методы улавливания серы пригодны для очистки газов, содержащих более $2 \%$ об. сернистого ангидрида. При снижении содержания сернистого ангидрида нижеуказанного уровня очистка газов считается слишком дорогостоящей и неэффективной [2].

Как показывает мировой опыт, ни одна из технологий улавливания серы не может быть успешно внедрена без опытной проверки в условиях деятельности реальной ТЭС [3]. В технической литературе известен ряд работ, направленных на высокоэффективное решение очистки отходящих газов ТЭС от $\mathrm{SO}_{2}$. К одним из них можно отнести технологию (снижение содержания $\mathrm{SO}_{2}$ из газов с содержанием $\mathrm{SO}_{2}$ менее $2 \%$ об. до 0,003\% об.) с использованием эвтектики карбонатов щелочных металлов $(\mathrm{Na}, \mathrm{K}, \mathrm{Li})[4,5]$. Однако данная технология не нашла широкого применения на практике из-за сложности процесса дальнейшей химической регенерации карбонатно-сульфатного расплава. Регенерация расплава проводилась исключительно при высоких температурах 1123-1173К путем многоступенчатого химического процесса. При высоких температурах карбонатно-сульфатные расплавы становились агрессивными и, реагируя с камерой реактора, выполненной из нержавеющей стали, подвергали ее коррозии [6]. Данный недостаток технологии успешно был устранен в работе [7], где было предложено решение проводить процесс химической регенерации карбонатно-сульфатного расплава путем восстановления монооксидом углерода при температурах 753-823К.

Цель настоящей работы - проведение укрупненнолабораторных исследований процесса химической регенерации карбонатно-сульфатного расплава путем восстановления монооксидом углерода с установлением оптимальных параметров процесса, необходимых для отработки общей концепции технологии глубокой очистки отходящих газов ТЭС в промышленных условиях.

\section{ПРИНЦИПИАЛЬНАЯ СХЕМА \\ УКРУПНЕННО-ЛАБОРАТОРНОЙ УСТАНОВКИ И МЕТОДИКА ПРОВЕДЕНИЯ ОПЫТОВ}

Технологическая схема укрупненно-лабораторной установки для исследования процесса химической регенерации карбонатно-сульфатного расплава путем восстановления монооксидом углерода представлена на рис.1.

Методика проведения опытов заключалась в следующем. В реактор 3, выполненный в виде цельносварного тигля, загружали исходную смесь карбонатно-сульфатного расплава. Тигель сверху затыкался съемной крышкой 5. На крышке сделаны три отверстия различного диаметра: через отверстие диаметром 12 мм из баллона 6 осуществляется подача СО в расплав для его восстановления, центральное отверстие диаметром 20 мм предусмотрено для отбора контрольных проб. Размеры отверстий выбраны так, чтобы обеспечивался свободный ход продувочной трубки 9 диаметром 10 мм и прутка из нержавеющей стали для отбора проб 10 диаметром 10 мм. Третье отверстие диаметром 7 мм предназначено для установления алундовой трубки 11 для отвода отходящих газов из реактора 3. Тигель с навеской загружали в печь 1 и плотно устанавливали на предусмотренную в печи подставку 2. Подачу СО в расплав для его восстановления осуществляли из баллона 6. Расход подаваемого на восстановление газа контролировали с помощью крана 7 и реометра 8.

В ходе проведения опытов через каждые 10 мин. периодически отбирали контрольные пробы ( 15 г) на холодный металлический пруток (проба на «ломок»), которые подвергали химическому и рентгеноструктурному методу анализа на содержание в них серы. Измерения проводили с использованием рентгенофлуоресцентного лабораторного прибора РЛП-21 [8].

Отходящие газы, содержащие COS, улавливались в системе сосудов 12 с заранее приготовленным раствором, состоящим из 1,8 моль $\mathrm{KOH}$ и 1,5 моль $\mathrm{H}_{2} \mathrm{O}_{2}$. Конец шланга, опущенный в сосуд с раствором, в момент отбора контрольной пробы расплава перебрасывался в очередной сосуд, что позволяло вести контроль количества выделяемого COS-газа и элементной серы в определенный промежуток времени восстановления расплава.

Наличие COS в газовой фазе идентифицировали с осаждением элементной серы, выделяемой в результате протекания реакции: 
$\mathrm{COS}+2 \mathrm{KOH}+\mathrm{H}_{2} \mathrm{O}_{2} \rightarrow \mathrm{K}_{2} \mathrm{CO}_{3}+2 \mathrm{H}_{2} \mathrm{O}+\mathrm{S} \downarrow$.

Протекание реакции (1) сопровождается исключительно с осаждением серы в ловушке раствора без образования каких-либо других газов. Это в свою очередь подтверждает образование COS-газа вследствие протекания реакции взаимодействия сульфата калия с монооксидом углерода:

$\mathrm{K}_{2} \mathrm{SO}_{4}+4 \mathrm{CO}=\mathrm{K}_{2} \mathrm{CO}_{3}+\cos \uparrow+2 \mathrm{CO}_{2} \downarrow$.

По окончании опыта осадок серы, полученный в результате титрования COS-газа, отделяли от раствора фильтрованием. Полученный после сушки при температуре $130^{\circ} \mathrm{C}$ осадок взвешивали.

Измерение температуры расплава во время опытов осуществляли хромель-алюмелевой термопарой 13. Температуру расплава в печи регулировали при помощи вторичного прибора КСП-4 (14). Опыты проводились при постоянной температуре - 823K.

Предварительными опытами было установлено, что при расходе СО, необходимого для восстановления сульфата калия по стехиометрии реакции (2), достичь максимальной эффективности его восстановления не удается: при продолжительности опыта, равной $\tau=45$ мин., степень восстановления сульфата калия составила 97\%.

Увеличение степени восстановления сульфата калия до 99\% достигнуто при расходе СО, превышающем в 1,5 раза его расход от стехиометрически необходимого по реакции (2), при аналогичном времени ведения опыта. Однако значительный избыточный расход СО, затрачиваемый на восстановление расплава, с точки зрения экономической эффективности, по нашему мнению, представляется не совсем корректным. Исходя из проведенных опытов, было принято решение процесс регенерации карбонатно-сульфатного расплава монооксидом углерода проводить при расходе СО, превышающем его расход на величину не более 10\% от стехиометрии при продолжительности восстановления сульфата, равной $\tau=60$ мин. Расход монооксида углерода во всех опытах был постоянным и составлял 61,2 л/ч.

Количество исходного расплава в проведенных опытах было постоянным и составило 350 г (+/- 5\%).

Предварительные результаты элементного анализа проб исходной смеси, полученные рентгенофлуоресцентным методом анализа, показали хорошую сходимость с результатами химического метода анализа на содержание в них серы. Состав исходной пробы в пересчете на карбонат натрия, лития и сульфат калия в среднем содержал \% масс.: $\mathrm{Na}_{2} \mathrm{CO}_{3}-30,91$; $\mathrm{Li}_{2} \mathrm{CO}_{3}-51,02 ; \mathrm{K}_{2} \mathrm{SO}_{4}-18,07$. Содержание серы в полученном карбонатно-сульфатном расплаве составило 5,7\%, или 19,94 г.

\section{РЕЗУЛЬТАТЫ ОПЫТОВ И ИХ ОБСУЖДЕНИЕ}

Результаты опытов по регенерации карбонатно-сульфатного расплава монооксидом углерода показаны на рис. 2.

Установлено, что содержание серы в расплаве снижается с увеличением расхода СО, про- пускаемого через расплав, и достигает минимальных значений при расходе СО, равном 61,38 л (см. puc. 2, a).

Нетрудно видеть (см. рис. 2, б), что при увеличении расхода СО общий характер закономерности снижения количества серы в расплаве, как для лабораторных опытов [9], так и для проведенных укрупненно-лабораторных опытов практически идентичен. При низких расходах СО (до 40 л) снижение остаточного количества серы в расплаве, независимо от заданных исходных параметров опытов (различная исходная концентрация сульфата), для двух рассматриваемых случаев остается практически линейными.

При дальнейшем увеличении расхода СО (более 40 л) линии зависимости снижения серы в расплаве приближаются к минимальному своему значению, что свидетельствует о полном восстановлении сульфата калия до своего карбоната и максимальном извлечении серы из расплава. Отметим, что в лабораторных опытах для полного удаления серы из расплава (исходное содержание серы в расплаве - 4,63 г) было израсходовано примерно в два раза больше $\mathrm{CO}$, превышающем его расход от теоретически необходимого по стехиометрии реакции (2). В то же время в условиях укрупненно-лабораторных опытов для удаления значительно большего количества серы ( 20 г) из расплава потребовался расхода СО на $\sim 10 \%$ больше от теоретического его расхода, необхо-

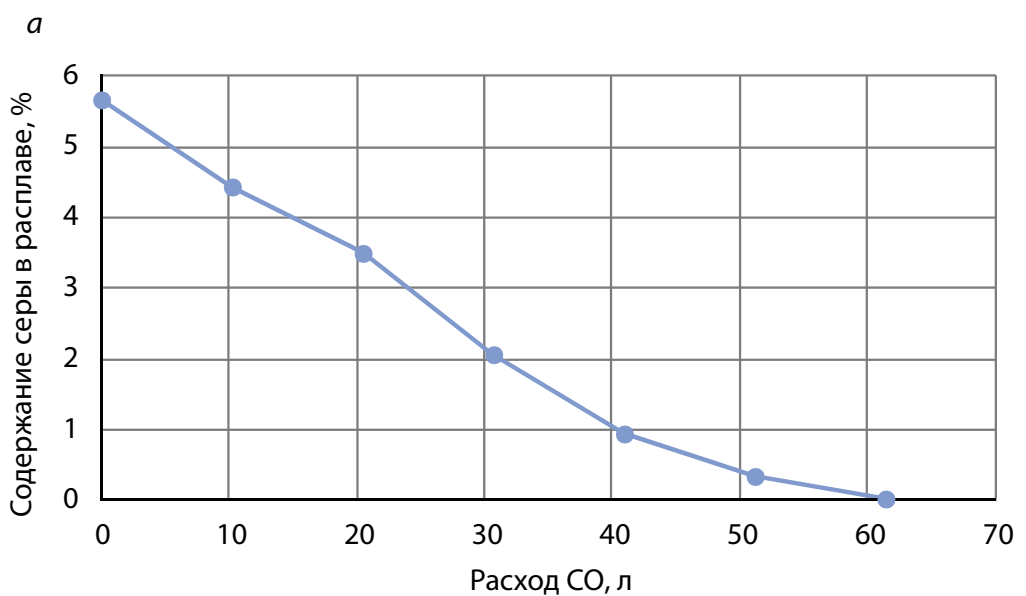

6

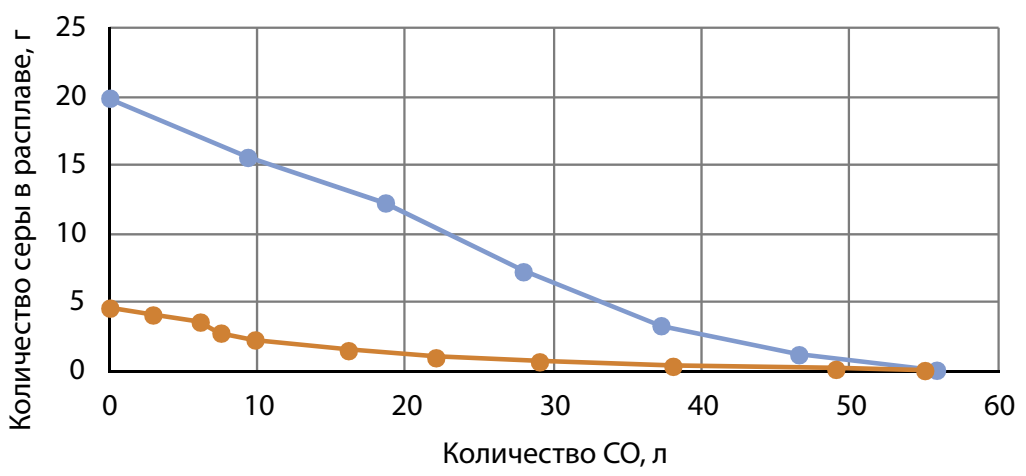

—— Укрупненно лаборатарные данные - - Лабораторные данные

Рис.2. Динамика восстановления карбонатно-сульфатного расплава в зависимости от расхода СО: $а$ - изменение содержания серы в расплаве oт расхода СО; б - изменение количества серы в расплаве от расхода СО Fig. 2. Carbonate - sulfate molten material recovery dynamics depending on $\mathrm{CO}$ flow rate: $a$ - molten material sulfur content variability depending on $\mathrm{CO}$ flow rate; $b$-molten material sulfur amount variability depending on CO flow rate 
Количество COS-газа и серы, выделяемое при восстановлении сульфата калия монооксидом углерода

\begin{tabular}{|c|c|c|c|c|c|}
\hline $\begin{array}{c}\text { № } \\
\text { пробы }\end{array}$ & $\begin{array}{c}\text { Время опыта, } \\
\text { мин. }\end{array}$ & $\begin{array}{c}\text { Количество } \\
\text { СО, л }\end{array}$ & $\begin{array}{c}\text { Количество СОS-газа, г } \\
\text { (по расчету) }\end{array}$ & $\begin{array}{c}\text { Количество серы в COS, г } \\
\text { (по расчету) }\end{array}$ & $\begin{array}{c}\text { Количество осажденной } \\
\text { серы, г (по опыту) }\end{array}$ \\
\hline 1 & 5 & 10,23 & 6,23 & 3,32 & 3,10 \\
\hline 2 & 10 & 20,46 & 14,40 & 7,68 & 7,62 \\
\hline 3 & 20 & 30,69 & 24,15 & 12,88 & 12,83 \\
\hline 4 & 35 & 40,92 & 31,50 & 16,80 & 16,75 \\
\hline 5 & 45 & 51,15 & 35,55 & 18,96 & 18,93 \\
\hline 6 & 60 & 61,38 & 37,37 & 19,84 & 19,80 \\
\hline
\end{tabular}

димого по стехиометрии реакции (2). Это свидетельствует о том, что при масштабировании процесса химической регенерации карбонатно-сульфатного расплава путем восстановления его монооксидом углерода незначительного избытка СО ( 10\%) вполне достаточно для полного восстановления сульфата калия до его карбоната.

Сравнительный анализ результатов расчетных значений количества серы, выделяемой по стехиометрии реакции (2) в форме COS-газа, в зависимости от расхода CO с количеством выделенной в осадок серы, полученной в ходе проведения экспериментов путем титрования COS-содержащих газов смесью $\mathrm{KOH}+\mathrm{H}_{2} \mathrm{O}_{2}$, показал хорошую сходимость между собой.

Значения расчетных и полученных в результате проведения опытов искомых величин приведены в табл.

На рис. 3, а показана зависимость расчетного количества серы, удаленной из расплава в форме COS-газа, и количества осажденной серы от расхода СО. Общий тренд изменения концентрации COS-газа и количества осажденной серы из карбонатно-сульфатного расплава в сторону повышения показывает динамику удаления серы из расплава с ростом расхода СО. Практически полное (до 99,94\%) извлечение серы из расплава достигается при продувке расплава СО при его расходе, равном 61,38 л (рис. 3, б).

Таким образом, в результате укрупненнолабораторных опытов установлено, что при температуре $823 \mathrm{~K}$ достигается практически полное (до 99,9\%) восстановление сульфата калия монооксидом углерода с удалением серы из расплава в форме COS-газа, пригодной для получения товарного продукта - элементной серы и/или серной кислоты. Незначительное время 60 мин и затраченное при этом для полного восстановления сульфата калия количество СО ( 60 л) доказывают, что в условиях интенсивного перемешивания расплава газом (СО) восстановление сульфата калия протекает с достаточно высокой скоростью.

Полученные экспериментальные данные кинетических кривых, устанавливающие зависимость изменения концентрации серы в расплаве и COS-газа в газовой фазе от расхода СО, позволяют определить и провести оценку кинетических параметров реакции восстановления сульфата калия монооксидом углерода.

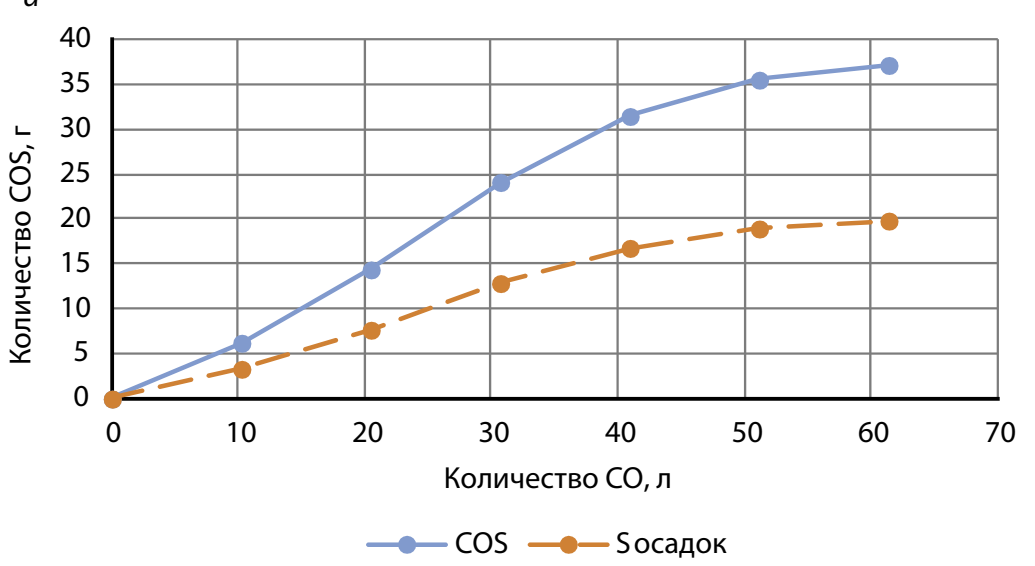

6

Puc.3. Динамика удаления серы из расплава в форме COS-газа (a) и зависимость извлечения серы из расплава от расхода СО (б)

Fig. 3. Dynamics of sulfur release from molten metal as COS-gas (a) and sulfur release from molten material depending on CO flow rate (b)

\section{РАСЧЕТ КИНЕТИЧЕСКИХ ПАРАМЕТРОВ РЕАКЦИИ ВОССТАНОВЛЕНИЯ СУЛЬФАТА КАЛИЯ МОНООКСИДОМ УГЛЕРОДА \\ Расчет энергии Гиббса \\ и константы скорости реакции}

Расчет энергии Гиббса $\left(\Delta G_{T}\right)$ реакции восстановления сульфата калия монооксидом углерода проводили при стандартном состоянии чистый переохлажденный жидкий сульфат $\left(\mathrm{K}_{2} \mathrm{SO}_{4 \text { liquid }}\right)$ и карбонат калия $\left(\mathrm{K}_{2} \mathrm{CO}_{3 \text { liquid }}\right)$. Исходные данные для расчетов получены из работы [10] и веб-сайта NIST-JANAF Thermo chemical Tables (http://kinetics.nist.gov/ janaf).

Термодинамические расчеты энергии Гиббса реакции (2) в температурном интервале 823-1173К проведены по специально разработанной авторами работы программе. 
Сравнительный анализ результатов термодинамических расчетов реакции (2) с данными, полученными с использованием программы Thermo Base 2.15, показал хорошую сходимость конечных значений искомых величин свободной энергии Гиббса с результатами авторов настоящей работы.

Расчет значений константы скорости реакции в исследованном температурном интервале проведен с использованием уравнения:

$$
\Delta G_{T}=-R T \ln K_{p} \text {, }
$$

где: $R$ - универсальная газовая постоянная, Дж/(моль·К); $T$ - температура, К; $K_{p}$ - константа скорости реакции.

Установлено, что наиболее отрицательное значение энергии Гиббса реакции (2) соответствует температуре $823 \mathrm{~K}$, которое составляет $\Delta G_{823 \mathrm{~K}}=-120$ кДж/моль. С увеличением температуры значение энергии Гиббса снижается и при температуре $1173 \mathrm{~K}$ составляет $\Delta G_{1173 \mathrm{~K}}=-60$ кДж/ моль. Константа скорости реакции с повышением температуры снижается и при температурах $823 \mathrm{~K}$ и $1173 \mathrm{~K}$ соответствует значениям $K_{823 \mathrm{~K}}=3,3 ; K_{1173 \mathrm{~K}}=2,1$ соответственно.

Установленные расчетные значения энергии Гиббса и константы скорости реакции (2) в исследованном температурном интервале в дальнейшем были использованы для определения кинетических параметров реакции (2).

\section{Расчет энергии активации}

Для расчета энергии активации использовано уравнение Аррениуса:

$$
K_{p}=A \cdot e^{-E / R T} \text {, }
$$

где: $A$ - предэкспоненциальный множитель; $E$ - энергия активации; $R$ - универсальная газовая постоянная, Дж/ (моль·К); $T$ - температура, К.

Уравнение (4) можно применять и для большинства реакций со сложным механизмом протекания. Прологарифмировав уравнение (4), можно записать следующее выражение:

$$
\ln K_{p}=\ln A-(E / R \cdot 1 / T) .
$$

Если данное уравнение для искомой нашей реакции (2) справедливо, то на графике в координатах $\ln K_{p}-1 / T$ опытные точки должны расположиться на прямой линии под углом $а$ к оси абсцисс и с угловым коэффициентом (тангенсом угла наклона), равным $E / R$. Тогда значение энергии активации можно определить исходя из выражения $E=R \operatorname{tg} \alpha$.

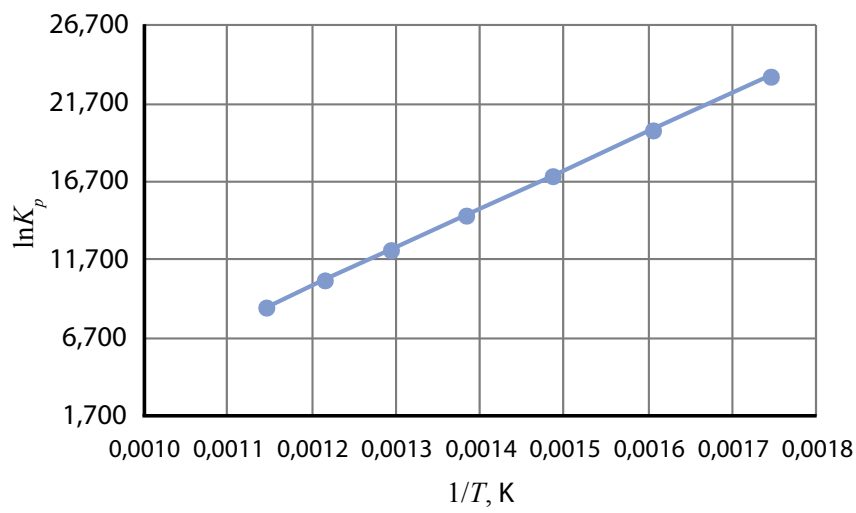

Рис.4. Зависимость константы скорости $\ln K_{p}$ реакции (2) om температуры

Fig. 4. Reaction $\ln K_{p}$ speed constant (2) - temperature relationship
График изменения константы скорости реакции $\left(\ln K_{p}\right)$ от температуры (рис. 4), построенный для искомой реакции (2), показывает линейную зависимость и позволяет определить энергию активации данной реакции.

Исходя из рис. 4 значение энергии активации составляет $E=10,92$ кДж/моль, что указывает на наличие диффузионной области, обусловленной торможением скорости реакции (2) за счет побочного взаимодействия сульфатов щелочных металлов с их карбонатами.

Величина предэкспоненциального множителя, исходя из уравнения (5), при температуре $823 \mathrm{~K}$ составит: $\ln A=10,44$, откуда $A=2,35$.

\section{Расчет порядка реакции}

Для расчета порядка реакции по заданному веществу использованы выражения для зависимости концентрации вещества от времени (уравнения кинетических кривых), полученные после интегрирования уравнения вида:

$$
-d c / d \tau=K c^{n} \text { или } K d \tau=-d c / c^{n} .
$$

После интегрирования уравнения (6) в пределах от 0 до $\tau$ и от $C_{o}$ до $C$ при $n=1,2$ можно получить следующие уравнения:

$$
\begin{aligned}
& \ln C=\ln C_{\mathrm{o}}-K \tau \text { при } n=1 ; \\
& C^{-1}=C_{\mathrm{o}}^{-1}+K \tau \text { при } n=2 .
\end{aligned}
$$

Как видно из уравнений (7), (8) графики, построенные по опытным данным изменения концентраций рассматриваемого исходного вещества в разные моменты времени протекания реакции, должны выражаться прямой линией в разных координатах в зависимости от порядка данной реакции по веществу. Для реакции (2) в качестве исходного вещества выбрано количество выделяемого в разные моменты времени COS-газа. Графики изменения количества COS-газа от времени, построенные в координатах: $\ln C-\tau$, при $n=1$ и $C^{-1}-\tau$, при $n=2$, показаны на рис. 5 .

Нетрудно видеть, что механизм процесса химической регенерации карбонатно-сульфатного расплава путем восстановления монооксидом углерода не может быть описан простой реакцией первого порядка. Установленный прямой ход зависимости изменения концентрации $\operatorname{COS}$ от времени в координатах $C^{-1}-\tau$ указывает на порядок реакции $n=2$.

Установленные значения энергии активации ( $E=10,92$ кДж/моль) и порядка реакции $(n=2)$ полностью подтверждают вывод о том, что механизм процесса химической регенерации карбонатно-сульфатного расплава путем восстановления монооксидом углерода описывается протеканием реакции восстановления сульфата калия монооксидом углерода и побочных реакций, протекающих между сульфатами и карбонатами щелочных металлов. При этом можно утверждать, что скорость основной реакции (2) остается достаточно высокой и доминирует по отношению к побочным реакциям за счет создания условий интенсивного перемешивания расплава газом.

Полученные результаты и установленные на их основе закономерности использованы при проведении балансовых испытаний по сжиганию угля и отработке процесса химической абсорбции отходящих газов карбонатным расплавом щелочных металлов и регенерации 
карбонатно-сульфатных расплавов путем восстановления монооксидом углерода в опытно-промышленных условиях.

Как отмечалось выше, наибольший ущерб окружающей среде наносит выброс бедных серосодержащих газов, получаемых при производстве цветных металлов (Cu, Ni, Pb, Zn) [11], хотя при соответствующей дальнейшей очистке вполне можно использовать их для получения элементной серы [12]. Большой интерес представляет использование в качестве восстановителя при химической регенерации карбонатно-сульфатного расплава природного газа, широко применяемого в металлургической практике [13]. В этом случае можно ожидать, что конечным продуктом при регенерации будет газообразный сероводород, который легко может быть доведен до промышленно полезных продуктов [14].

\section{выводы}

Разработана укрупненно-лабораторная установка для исследования процесса химической регенерации карбонатно-сульфатного расплава. Проведены исследования по восстановлению карбонатно-сульфатного расплава состава, \%: $\mathrm{Na}_{2} \mathrm{CO}_{3}-30,91 ; \mathrm{Li}_{2} \mathrm{CO}_{3}-51,02$; $\mathrm{K}_{2} \mathrm{SO}_{4}-18,07$ монооксидом углерода при температуре $550^{\circ} \mathrm{C}$. Установлено, что при продолжительности продувки расплава монооксидом углерода в течение 60 мин. достигается максимальное удаление серы из расплава в форме COS. Извлечение серы из расплава составляет более $99 \%$.

На основании экспериментальных результатов рассчитаны кинетические параметры процесса химической регенерации карбонатно-сульфатного расплава путем восстановления монооксидом углерода. Рассчитано значение энергии активации $E=10,96$ кДж/моль и определен порядок реакции $n=2$. Показано, что процесс химической регенерации карбонатно-сульфатного расплава описывается сложным механизмом: взаимодействием сульфатов щелочных металлов с СО и протеканием обменных реакций между карбонатами щелочных металлов с их сульфатами.

Полученные результаты использованы при отработке технологии очистки отходящих газов на котельной установке К-19 АО «Энергоорталык-3», включающей проведение балансовых испытаний процесса сжигания угля, химической абсорбции отходящих газов карбонатным расплавом щелочных металлов и регенерации карбонатно-сульфатного расплава путем восстановления монооксидом углерода.

\section{Список литературы}

1. Калыгин В.Г. Промышленная экология: учебное пособие для вузов. М.: Академия, 2010. 432 с.

2. Nolan P. Flue Gas Desulfurization Technologies for CoalFired Power Plants. Coal-Tech 2000 International Conference. Indonesia, Jakarta. 2000.
3. Алиев Г.М. Техника пылеулавливания и очистки промышленных газов. М.: Металлургия, 2012. 544 с.

4. Yosim S.J., Grantham L.F., Mckenzie D.E., Stegmann G.C. Chemistry of Molten Carbonate Process for Sulfur Oxides Removal from Stack Gases // Advances in Chemistry Series. 1973. 174 p.

5. Mcillroy R.A., Atwood G.A., Major C.J. Absorption of SulfurDioxide by Molten Carbonates. // Env. Sc. Technol. 1973. № 7. Pp.1022.

6. Krebs T., Nathanson G.M. Reactive collisions of sulfur dioxide with molten carbonates // Proc. Natl. Acad. Sci. U.S.A. 2010. 107(15). Pp. 6622-6627.

7. Kaplan V., Wachtel E., Lubomirsky I. Carbonate melt regeneration for efficient capture of $\mathrm{SO}_{2}$ from coal combustion // RSC Adv. 2013. 3(36). pp. 15842-15849.

8. Zhumagulov B.T., Tuleshov A.K., Dosmukhamedov N.K., Lezin A.N. The innovations in Kazakhstan's economy: Analytical instrument making development prospects // International Journal of Experimental Education. 2013. № 12. Pp. 24-26.

9. Досмухамедов Н.К., Жолдасбай Е.Е., Каплан В.А., Нурлан Г.Б. Извлечение серы из сульфатно-карбонатного расплава щелочных металлов восстановлением монооксидом углерода // Горный Журнал Казахстана. 2016. № 2. С. 28-33.

10. Turkdogan E.T. Physical Chemistry of High Temperature Technology. Academic Press. 1980. 462 p. 
11. Crundwell F.K., et al. Extractive Metallurgy of Nickel, Cobalt and Platinum-Group Metals. Elsevier, Oxford. 2011. $583 \mathrm{p}$.

12. Habashi F. Copper metallurgy at the crossroads // J. Min. Metall., Sect. B. 2007. 43(1). Pp. 1-19.
13. Schlesinger M.E., et al. Extractive Metallurgy of Copper. Elsevier, Amsterdam. 2011. 455 p.

14. Ashar N.G., Golwalkar K.R. A Practical Guide to the Manufacture of Sulfuric Acid, Oleums and Sulfonating Agents. London Springer, New York. 2013. 152 p.

UDC 662.61:66.071.9:66.074.3 @ N.K. Dosmukhamedov, E.E. Zholdasbay, V.A. Kaplan, 2018

ISSN 0041-5790 (Print) • ISSN 2412-8333 (Online) • Ugol' - Russian Coal Journal, 2018, № 1, pp. 74-80

\section{Title \\ TECHNOLOGY OF WASTE GAS PURIFICATION FROM TPP FROM SULFUR: REGENERATION OF CARBONATE-SULFATE MELT CARBON MONOXIDE}

DOI: http://dx.doi.org/10.18796/0041-5790-2018-1-74-80

\section{Authors}

Dosmukhamedova N.K. ${ }^{1}$, Zholdasbay E.E. ${ }^{1}$, Kaplan V.A. ${ }^{2}$

${ }^{1}$ K.I. Satpayev Kazakh National Technical University, Almaty, 050013, Republic of Kazakhstan

${ }^{2}$ Weizmann Institute of Science, Rishon Le Zion, 37270, Israel

\section{Authors' Information}

Dosmukhamedov N.K., PhD (Engineering), Professor, Associated Professor, e-mail: nurdos@bk.ru

Zholdasbay E.E., Research Assistant, e-mail: nurdos@bk.ru

Kaplan V.A., PhD (Engineering), Scientific Adviser, tel.: +7 (972) 542-31-14-31

\section{Abstract}

The lack of a reliable flue gas cleaning system and the use of old methods of trapping $\mathrm{SO}_{2}$ and other harmful pollutants of the atmosphere led to an increase in their concentrations in emissions above the maximum permissible standards. Air pollution with sulfur dioxide has become one of the most serious problems that need to be addressed urgently.

One of the promising solutions for deep purification of waste gases from TPP from sulfurous anhydride is technology based on the absorption of $\mathrm{SO}_{2}$ by a molten mixture of alkali metal carbonates. The introduction of technology is hampered by the lack of a reliable method for regenerating the sulfatecarbonate melt.

In the present work, the results of large-scale laboratory tests of the process of chemical regeneration of the carbonate-sulfate melt by reduction with carbon monoxide are presented. Studies have been carried out to restore the carbonate-sulfate melt composition, \%: $\mathrm{Na}_{2} \mathrm{CO}_{3}-30.91 ; \mathrm{Li}_{2} \mathrm{CO}_{3}$ $51.02 ; \mathrm{K}_{2} \mathrm{SO}_{4}-18.07$ carbon monoxide at a temperature of $550{ }^{\circ} \mathrm{C}$. It was found that with the duration of blowing the melt with carbon monoxide for $60 \mathrm{~min}$, the maximum removal of sulfur from the melt in the form of COS is achieved. The recovery of sulfur from the melt is more than $99 \%$. Based on the experimental results, the kinetic parameters of the process of chemical regeneration of the carbonate-sulphate melt by carbon monoxide reduction were calculated. The value of the activation energy $\mathrm{E}=10.96 \mathrm{~kJ} /$ mol is calculated and the order of the reaction $n=2$ is determined. It is shown that the process of chemical regeneration of the carbonate-sulfate melt is described by a complex mechanism: the interaction of alkali metal sulfates with $\mathrm{CO}$ and the course of exchange reactions between alkali metal carbonates and their alkali metal carbonates sulfatesThe obtained results were used to develop the technology of waste gas purification at the K-19 boiler house of JSC Energoortalik-3, including balance tests of coal combustion, chemical absorption of waste gases by the carbonate melt of alkali metals and regeneration of the carbonate-sulphate melt by reduction with carbon monoxide. Figures:

Fig. 1. Lab unit aggregated schematic: 1 - oven; 2 - reactor basement; 3 - reactor; 4 - molten material; 5 - potable lid; 6 - CO bottle; 7 - tap; 8 - flowmeter 9 - purging rube; 10 - sampling device; 11 - off-gas pipe; 12 - titration vessels; 13 - chromel-alumel thermocouple; 14 - potentiometer KSP-4

Fig. 2. Carbonate - sulfate molten material recovery dynamics depending on $C O$ flow rate: $a$-molten material sulfur content variability depending on CO flow rate; $b$ - molten material sulfur amount variability depending on CO flow rate Fig. 3. Dynamics of sulfur release from molten metal as COS-gas (a) and sulfur release from molten material depending on $\mathrm{CO}$ flow rate (b)
Fig. 4. Reaction $\ln K$ speed constant (2) - temperature relationship

Fig. 5. COS-gas quantity - time relationship: $a$ - at $n=1 ; b-a t n=2$

\section{Keywords}

Coal, Sulfurous anhydride, Sulfate-carbonate melt, Carbon monoxide, Regeneration, COS-gas.

\section{References}

1. Kalygin V.G. Promyshlennaya ekologiya uchebnoe posobie dlya vuzov [Industrial ecology: high school education aid]. Moscow, Akademiya Publ., 2010, $432 \mathrm{p}$.

2. Nolan P. Flue Gas Desulfurization Technologies for Coal-Fired Power Plants. Coal-Tech 2000 International Conference. Indonesia, Jakarta, 2000.

3. Aliev G.M. Tekhnika pyleulavlivaniya i ochistki promyshlennyh gazov [Industrial gas dust extraction and treatment technique]. Moscow, Metallurgiya Publ., 2012, 544 p.

4. Yosim S.J., Grantham L.F., Mckenzie D.E. \& Stegmann G.C. Chemistry of Molten Carbonate Process for Sulfur Oxides Removal from Stack Gases. Advances in Chemistry Series, 1973, 174 p.

5. Mcillroy R.A., Atwood G.A. \& Major C.J. Absorption of Sulfur-Dioxide by Molten Carbonates. Env. Sc. Technol., 1973, No. 7, pp. 1022.

6. Krebs T. \& Nathanson G.M. Reactive collisions of sulfur dioxide with molten carbonates. Proc. Natl. Acad. Sci. U.S.A., 2010, 107(15), pp. 6622 6627.

7. Kaplan V., Wachtel E. \& Lubomirsky I. Carbonate melt regeneration for efficient capture of $\mathrm{SO}_{2}$ from coal combustion. RSC Adv., 2013, 3(36), pp. 15842-15849.

8. Zhumagulov B.T., Tuleshov A.K., Dosmukhamedov N.K. \& Lezin A.N. The innovations in Kazakhstan's economy: Analytical instrument making development prospects. International Journal of Experimental Education, 2013, No. 12 , pp. 24-26

9. Dosmukhamedov N.K., Zholdasbay E.E., Kaplan V.A. \& Nurlan G.B. Izvlechenie sery iz sulfatno-karbonatnogo rasplava shchelochnyh metallov vosstanovleniem monooksidom ugleroda [Sulfur release from sulfatecarbonate molten alkaline metal by carbon monoxide reduction]. Gornyy Zhurnal Kazahstana - Kazakhstan Mining Journal. 2016, No.2, pp. 28-33. 10. Turkdogan E.T. Physical Chemistry of High Temperature Technology. Academic Press. 1980.462 p.

11. Crundwell F.K. et al. Extractive Metallurgy of Nickel, Cobalt and PlatinumGroup Metals. Elsevier, Oxford, 2011, 583 p.

12. Habashi F. Copper metallurgy at the crossroads. J. Min. Metall., Sect. B, 2007, 43(1), pp. 1-19.

13. Schlesinger M.E. et al. Extractive Metallurgy of Copper. Elsevier, Amsterdam, 2011, $455 \mathrm{p}$.

14. Ashar N.G. \& Golwalkar K.R. A Practical Guide to the Manufacture of Sulfuric Acid, Oleums, and Sulfonating Agents. London Springer, New York, 2013, 152 p. 


\section{Исследование условий формирования и характеристик лесных экосистем в отработанных щебеночных карьерах в Красноярском крае*}

DOI: http://dx.doi.org/10.18796/0041-5790-2018-1-81-83

\author{
ЗЕНЬКОВ Игорь Владимирович \\ Доктор техн. наук, Заслуженный эколог РФ, \\ Институт вычислительных технологий СО РАН, \\ профессор ФГАОУ ВО «СИбирский \\ федеральный университет», \\ 660041 , г. Красноярск, Россия \\ e-mail:zenkoviv@mail.ru
}

\section{БАРАДУЛИН Илья Михайлович}

Аспирант

ФГАОУ ВО «Сибирский федеральный университет», 660041 , г. Красноярск, Россия

В статье представлены результаты многолетнего экологического мониторинга характеристик молодых экосистем, сформированных в действующих и отработанных щебеночных карьерах. Установлены уровни среднегодовых темпов прироста стволовой части сосны, а также исследовано влияние основных факторов на этот показатель. Представлены зависимости годовых темпов прироста сосны от географической ориентации нерабочих бортов карьеров и мощности продуктивной техногенной смеси, содержащей гумус и нанесенной на участки межуступных площадок карьеров с древесно-кустарниковой растительностью. Ключевые слова: открытые горные работы, шебеночные карьеры, ориентачия нерабочего борта карьера, экологические показатели, техногенная продуктивная смесь, лесные экосистемы.

\section{ВВЕДЕНИЕ}

На территории Красноярского края масштабное производство щебня началось в ходе строительства Транссибирской железной дороги в конце XIX века. К настоящему времени объем добычи нерудных горных пород

\footnotetext{
* Работа выполнялась в соответствии с Программой фундаментальных научных исследований государственных академий наук на 2013-2020 г2. и планом научно-исследовательских работ ИВТ СО РАН на 2017-2020 г2. согласно проекту «Теоретические основы, алгоритмическое обеспечение и информачионные технологии для решения фундаментальных и прикладных задач исследования сложных техногенных, природных и биологических систем».
}

для производства строительного и дорожного щебня существенно увеличился. В отработанных щебеночных карьерах архитектура горнопромышленного ландшафта представлена межуступными площадками и откосами нерабочих уступов. В них со временем формируется лесная экосистема путем самозаселения представителей смешанного леса или черневой тайги, находящихся вблизи карьеров. Считаем актуальным решение задач, связанных с изучением экологических проблем, неизбежно возникающих на землях с техногенными нарушениями при формировании растительных экосистем. Обзор зарубежной специальной литературы подтвердил актуальность наших работ, поскольку аналогичные исследования проводятся на территории всех континентов нашими коллегами - промышленными экологами $[1,2,3,4,5,6,7]$.

\section{РЕШЕНИЕ ПРОБЛЕМЫ}

В ходе полевых экспедиций, проведенных в период с 2012 по 2017 г. на двух карьерах, находящихся в западном направлении от пос. Зыково, на карьере по добыче доломита вблизи с. М. Кускун, на карьерах по добыче гранита вблизи пос. Громадский и на территории закрытого административного образования г. Зеленогорск, получены результаты, представленные ниже.

Годовые темпы прироста измерялись на соснах, поскольку в структуре смешанного леса этот вид занимает более $60 \%$ от количества всех деревьев, произрастающих в карьерах. К тому же именно на сосне расстояние между ярусами ветвей замеряются быстро и просто [8]. По результатам дистанционного мониторинга установлено, что наибольшие площади участков с древеснокустарниковой растительностью находятся на нерабочих бортах, ориентированных географически на запад и север, и наоборот, на участках нерабочих бортов, ориентированных на юг и восток, отмечены минимальные размеры участков с лесной экосистемой [9]. В этой связи, вся генеральная совокупность исследуемых деревьев, включающая 562 сосны, была условно поделена на четыре части (по ориентации нерабочих бортов), каждая из которых представлена в виде самостоятельного вариационного ряда. Совокупности в выделенных рядах были разбиты дополнительно на группы, значения 
признаков в которых были объединены в интервалы. В каждом ряду определены значения моды, модального интервала, а также установлен средний уровень ряда.

На участках восточных нерабочих бортов, обращенных на запад, обследовано 192 сосны. Минимальное и максимальное значение в этом вариационном ряду находятся на уровне 33 и 48 см (см. рисунок).

На участках южных нерабочих бортов, обращенных на север, обследовано 198 сосен. Минимальное и максимальное значения в этом вариационном ряду находятся на уровне 38 и 50 см. На участках западных нерабочих бортов карьеров, обращенных на восток, обследовано 88 сосен. Минимальное и максимальное значения в этом вариационном ряду находятся на уровне 27 и 42 см. На участках северных нерабочих бортов, обращенных на юг, обследовано 84 сосны. Минимальное и максимальное значения в этом вариационном ряду находятся на уровне 24 и $36 \mathrm{~cm}$.

Статистическая обработка вариационных рядов указала на наличие тесной и весьма тесной связи между годовыми темпами прироста сосны и географической ориентацией места произрастания в карьере.

После сопоставления полученных результатов прироста сосны на участках нерабочих бортов во всем диапазоне их географической ориентации был сделан вывод о том, что место произрастания деревьев оказывает значительное влияние на уровень этого показателя [10]. Аналогичный вывод сделан о значимости мощности техногенной продуктивной смеси, нанесенной на исследуемые участки.

Сравнительный анализ показал, что максимальные приросты сосны зафиксированы на участках южных бортов, обращенных на север, где средний уровень показателя составил 44,5 см. Немного ниже, в среднем на $11 \%$, темпы прироста наблюдаются на участках восточных нерабочих бортов. Невысокие показатели на уровне 35 см отмечены на участках западных нерабочих бортов, обращенных на восток. Самые низкие темпы, на уровне 30 см, в 1,5 раза ниже, чем на южных бортах, зафиксированы на северных бортах карьеров, где в ясную погоду склоны прогреваются до $50-60^{\circ} \mathrm{C}$.

При изменении мощности техногенной продуктивной смеси в среднем с 12,5 см до 1 м и более среднегодовой темп прироста деревьев увеличивался на 42\% и 22\% на участках нерабочих бортов, ориентированных соответственно на запад и север. При изменении мощности смеси в аналогичном диапазоне среднегодовой темп прироста деревьев увеличивается на $40 \%$ на участках нерабочих бортов с другой меридионально-широтной ориентацией. Таким образом, в ходе решения экологических задач на территории щебеночных карьеров в центральных районах Красноярского края были получены новые знания о формировании в них лесных экосистем.

\section{ЗАКЛЮЧЕНИЕ}

Итак, на основе анализа результатов многолетних полевых исследований установлены два важнейших фактора техногенного характера, оказывающие существенное влияние на условия появления и дальнейшего развития лесной экосистемы в отработанных щебеночных карьерах. Выявленные закономерности должны учитываться при формировании технического задания на проектирование горных работ по разработке и рекультивации месторождений общераспространенных полезных ископаемых, что позволит после завершения горных работ ускорить формирование экологического баланса в отработанных карьерах.

\section{Список литературы}

1. Cusser S., Goodell K. Diversity and Distribution of Floral Resources Influence the Restoration of Plant-Pollinator Networks on a Reclaimed Strip Mine // Restoration Ecology. 2013. Vol. 21(6). Pp. 713-721.

2. Sena K., Barton C., Hall S., Angel P., Agouridis C., Warner R. Influence of spoil type on afforestation success and natural vegetative recolonization on a surface coal mine in Appalachia, United States // Restoration Ecology. 2015. Vol. 23(2). Pp. 131-138.

3. Ngugil M.R., Neldner V.J., Doley D., Kusy B., Moore D., Richter C. Soil moisture dynamics and restoration of selfsustaining native vegetation ecosystem on an open-cut coal mine // Restoration Ecology. 2015. Vol. 23(5). Pp. 615-624.

4. Boldt-Burisch K., Naeth M. A., Schneider B., Hüttl R.F. Linkage between root systems of three pioneer plant species and soil nitrogen during early reclamation of a mine site in Lusatia, Germany // Restoration Ecology. 2015. Vol. 23(4). Pp. 357-365. 
5. Gilland K.E., McCarthy B.C. Microtopography Influences Early Successional Plant Communities on Experimental Coal Surface Mine Land Reclamation // Restoration Ecology. 2014. Vol. 22(2). Pp. 232-239.

6. Laarmann D., Korjus H., Sims A., Kangur A., Kiviste A., Stanturf J. A. Evaluation of afforestation development and natural colonization on a reclaimed mine site // Restoration Ecology. 2015. Vol. 23(3). Pp. 301-309.

7. Prach K., Karešová P., Jírová A., Dvořáková H., Konvalinková P., Řehounková K. Do not neglect surroundings in restoration of disturbed sites // Restoration Ecology. 2015. Vol. 23(3). Pp. 310-314.

8. Зеньков И.В., Барадулин И.М. Экологическая оптимизация в технологиях разработки месторождений строи- тельного щебня // Экология и промышленность России. 2015. T. 19. № 3. С. 40-44.

9. Зеньков И.В., Барадулин И.М., Юронен Ю.П. Дистанционное зондирование в инженерно-информационном обеспечении рекультивации щебеночных карьеров на территории Красноярского края и Иркутской области // Экология и промышленность России. 2016. Т. 20, № 4. C. $16-21$.

10. Зеньков И.В., Барадулин И.М. Обоснование конструкции нерабочих бортов щебеночных карьеров с учетом экологических целей // Уголь. 2016. № 3. С. 89-91. URL: http://www.ugolinfo.ru/Free/032016.pdf (дата обращения 15.12.2017).

UDC 622.85:622.271.45:550.814 @ I.V. Zenkov, I.M. Baradulin, 2018

ISSN 0041-5790 (Print) • ISSN 2412-8333 (Online) • Ugol' - Russian Coal Journal, 2018, № 1, pp. 81-83

\section{Title}

\section{STUDY RESULTS OF VEGETATION EMERGENCE AND FORMATION IN DEPLETED CRUSHED STONE QUARRIES IN KRASNOYARSK KRAI}

DOI: http://dx.doi.org/10.18796/0041-5790-2018-1-81-83

\section{Authors}

Zenkov I.V.' ${ }^{1,2}$, Baradulin I.M. ${ }^{2}$

1 Special Design and Technological Bureau "Nauka” of Institute computational technology of Siberian Branch Russian Academy of Sciences (SDTB “Nauka” ICT SB RAS), Krasnoyarsk, 660049, Russian Federation

${ }^{2}$ Federal State-Autonomous Educational Institution of Higher Professional Education (FSAEI HPE) Siberian Federal University, Krasnoyarsk, 660041, Russian Federation

\section{Authors' Information}

Zenkov I.V., Doctor of Engineering Sciences, Merited Ecologist of the Russian Federation, Professor, e-mail: zenkoviv@mail.ru

Baradulin I.M., Postgraduate

\section{Abstract}

The article presents the results of long-term environmental monitoring of young ecosystems. formed in active and abandoned crushed stone quarries. Pine stem part average annual growth values are established, and the main factors effect on this indicator are investigated. Pine growth annual rates dependence on quarries non-mining flanks geographical orientation and thickness of humus containing productive technogenic mix, deposited on quarries interstation sites arboreal and shrub vegetation are presented. Figures:

Fig. Pine growth annual rates dependence on quarries non-mining flanks geographical orientation and humus containing productive technogenic mix thickness

\section{Keywords}

Surface mining, Ballast quarries, Disturbed land reclamation, Technogenic soil mix, Vegetation ecosystems, Soil layer productivity.

\section{References}

1. Cusser S. \& Goodell K. Diversity and Distribution of Floral Resources Influence the Restoration of Plant-Pollinator Networks on a Reclaimed Strip Mine. Restoration Ecology, 2013, Vol. 21(6), pp. 713-721.

2. Sena K., Barton C., Hall S., Angel P., Agouridis C. \& Warner R. Influence of spoil type on afforestation success and natural vegetative recolonization on a surface coal mine in Appalachia, United States. Restoration Ecology, 2015, Vol. 23(2), pp. 131-138.

3. Ngugil M.R., Neldner V.J., Doley D., Kusy B., Moore D. \& Richter C. Soil mois ture dynamics and restoration of self-sustaining native vegetation ecosystem on an open-cut coal mine. Restoration Ecology, 2015, Vol. 23(5), pp. 615-624. 4. Boldt-Burisch K., Naeth M.A., Schneider B. \& Hüttl R.F. Linkage between root systems of three pioneer plant species and soil nitrogen during early reclamation of a mine site in Lusatia, Germany. Restoration Ecology, 2015 Vol. 23(4), pp. 357-365.

5. Gilland K.E. \& McCarthy B.C. Microtopography Influences Early Successional Plant Communities on Experimental Coal Surface Mine Land Reclamation. Restoration Ecology, 2014, Vol. 22(2), pp. 232-239.

6. Laarmann D., Korjus H., Sims A., Kangur A., Kiviste A. \& Stanturf J.A. Evaluation of afforestation development and natural colonization on a reclaimed mine site. Restoration Ecology, 2015, Vol. 23(3), pp. 301-309.

7. Prach K., Karešová P., Jírová A., Dvořáková H., Konvalinková P. \& Řehounková K. Do not neglect surroundings in restoration of disturbed sites. Restoration Ecology, 2015, Vol. 23(3), pp. 310-314.

8. Zenkov I.V. \& Baradulin I.M. Ekologicheskaya optimizatsiya v tekhnologiyah razrabotki mestorozhdeniy stroitelnogo shchebnya [Environmental optimization in crushed stone fields development technologies]. Ekologiya i promyshlennost Rossii - Environment and Industry of Russia, 2015, Vol. 19, No. 3, pp. 40-44.

9. Zenkov I.V., Baradulin I.M. \& Yuronen Yu.P. Distantsionnoe zondirovanie v inzhenerno-informatsionnom obespechenii rekultivatsii shchebenochnyh karerov na territorii Krasnoyarskogo kraya i Irkutskoy oblasti [Remote probing in engineering and information support of the crushed stone quarries reclamation in Krasnoyarsk Krai and Irkutsk region]. Ekologiya ipromyshlennost Rossii - Environment and Industry of Russia, 2016, Vol. 20, No. 4, pp. 16-21. 10. Zenkov I.V. \& Baradulin I.M. Obosnovanie konstruktsii nerabochikh bortov shchebenochnykh kar'erov s uchetom ekologicheskikh tseley [Ballast quarry nonmining bank design substantiation with account for environmental targets]. Ugol' - Russian Coal Journal, 2016, No. 3, pp. 89-91. Available at: http:// www.ugolinfo.ru/Free/032016.pdf (accessed 15.12.2017).

\section{Acknowledgments}

The work was performed in line with the 2013-2020 Program of Fundamental Scientific Research of the State Academies of Sciences and 2017-2020 scientific research plan of ICT SB RAS within the scope of the project "Theoretical bases, algorithmic support and information technologies for solving fundamental and applied problems of complex technogenic, natural and biological systems research". 


\section{Бородинские предприятия СУЭК \\ досрочно завершили производственный год}

Крупнейший в Красноярском крае и России Бородинский разрез имени М.И. Щадова, входящий в состав Сибирской угольной энергетической компании (СУЭК), в начале декабря 2017 г. досрочно выполнил годовой производственный план, который составлял 18 млн т. До конца года предприятие планировало отгрузить сверх плана еще свыше 1,5 млн т угля. Как подчеркнул управляющий Бородинским разрезом Николай Лалетин: «досрочное выполнение годовой программы по добыче угля - заслуга не только добычного участка, но и всего коллектива предприятия, $и$ ближайших партнеров разреза - железнодорожников Бородинского погрузочно-транспортного управления, сервисного подразделения СУЭК».

Кстати, погрузочно-транспортное управление также рапортовало о досрочном завершении производственного года. По словам управляющего Бородинским ПТУ Андрея Карпова: «план по объемам перевозки угля в 2017 г. составлял 17,5 млн т, вскрыши - 16 млн куб. м. Несмотря на ихвыполнение, железнодорожники не снижают темпов работы: до конца года они намерены перевезти дополнительно к плану еще около 1,5 млн т угля и столько же кубометров вскрышных пород. Бесперебойно обеспечивать растущие объемы поставок позволяет в том числе ввод в эксплуатацию трех дополнительных локомотивов».

С высокими производственными достижениями коллективы разреза и погрузочно-транспортного управления поздравил управляющий АО «СУЭК-Красноярск» Андрей Федоров. Он поблагодарил сотрудников предприятий за честный, добросовестный труд, подчеркнув, что за каждой тонной угля, за каждым кубометром вскрыши стоит труд сотен людей, и пожелал дальнейших успехов, крепкого здоровья, благополучия в семьях.

Таким образом, на начало декабря годовой план 2017 года выполнили все предприятия СУЭК в Бородино: 27 ноября о досрочном завершении программы реализации продукции отчитался Бородинский ремонтномеханический завод, выполняющий ремонты и изготовление запасных частей и оборудования для разрезов, шахт и обогатительных фабрик СУЭК от Кузбасса до Владивостока.

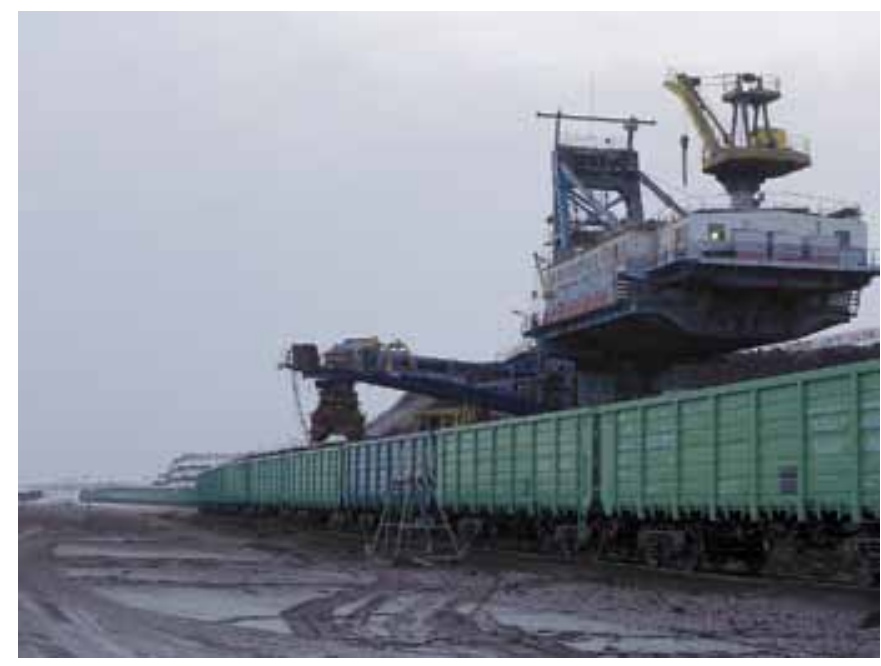

\section{СУЭК вошла в число лидеров рейтинга горнодобывающих компаний WWF}

11 декабря 2017 г. Всемирный фонд дикой природы представил результаты рейтинга экологической ответственности горнодобывающих и металлургических компаний. $А О$ «СУЭК» вошло в первую десятку рейтинга, а также в верхнюю пятерку раздела «Экологический менеджмент» и десятку лидеров раздела «Воздействие на окружающую среду».

Рейтинг экологической ответственности горнодобывающих и металлургических компаний проводится Всемирным фондом дикой природы (WWF) совместно с проектом ПРООН/ГЭФ/Минприроды России при участии Национального рейтингового агентства. Он позволяет сопоставить информацию об уровне экологической ответственности горнодобывающих компаний и масштабах воздействия их деятельности на окружающую среду, включая биоразнообразие. Впервые рейтинг был представлен в марте 2017 г., тогда $\mathrm{AO}$ «СУЭК» также вошло в число лидеров экологической ответственности.

Обеспечение экологической безопасности, минимизация экологических рисков производства и охрана природы являются неотъемлемой частью стратегии устойчивого развития СУЭК. Компания реализует комплекс мероприятий по охране воздушных ресурсов (дегазация шахт и утилизация метана), охране водных ресурсов (очистка сточных вод), энергоэффективности, рекультивации земель и сохранению биоразнообразия. В ближайшие два года инвестиции СУЭК в охрану окружающей среды составляют порядка 3,5 млрд руб.

Деятельность СУЭК в сфере экологии неоднократно отмечена профессиональным сообществом - компания является, в частности, победителем национальной премии EraEco (при поддержке UNIDO и Минприроды РФ), Evolution Awards, Eco Best Award. 


\section{ДРИЖД Николай Александрович}

\author{
(к 90-летию со дня рождения)
}

Шахтерам Караганды и всей горной общественности Казахстана и России хорошо известно имя дважды Лауреата Государственной премии СССР, Заслуженного горняка Казахской ССР, доктора технических наук, профессора, генерального директора производственного объединения «Карагандауголь» (с 1979 по 1989 г.) - Николая Александровича Дрижда - человека, жизненный и трудовой путь которого тесно связан с историей Карагандинского угольного бассейна и угольной промышленности СССР.

Николай Александрович родился 29 декабря 1927 г. в г. Балаково Саратовской области в семье служащего. После окончания с отличием Днепропетровского горного института им. Артема он прошел славный трудовой путь, работая начальником добычного участка на шахте № 37 треста «Ленинуголь» комбината «Карагандауголь», главным инженером шахты № 101, начальником шахты № 120 треста «Сараньуголь» и управляющим этого же треста. На всех постах его отличали незаурядные деловые качества, глубокие инженерные и экономические знания, нестандартные решения сложных производственных и социальных задач.

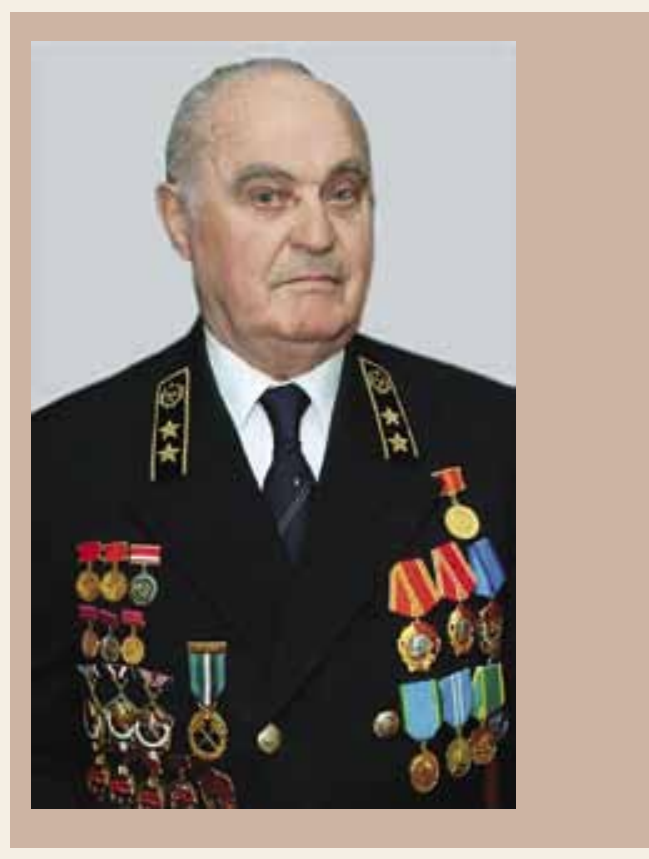

Наиболее ярко проявился его инженерный талант в ходе становления коллектива передовой в бассейне шахты им. В.И. Ленина объединения «Карагандауголь». Под его руководством шахта стала своеобразной школой передового опыта, эталоном умелой организации труда, в 1976 г. добыча шахты превысила 3 млн т угля, что было равно нагрузкам трех шахт бассейна. Коллектив шахты был удостоен ордена Трудового Красного Знамени.

Особой страницей в историю Карагандинского угольного бассейна вписана его многогранная деятельность генеральным директором крупнейшего в СССР объединения «Карагандауголь». Каждый его день в этой должности был насыщен напряженным ритмом, творчеством и трудовыми свершениями. Благодаря его инициативе и неиссякаемой энергии в кратчайшие сроки были освоены Борлинское и Шубаркольское угольные месторождения, на всех шахтах осваивалась передовая отечественная и зарубежная горная техника. С благодарностью и теплотой отмечают руководители и специалисты многих поколений горняков его исключительную целеустремленность, беспримерное трудолюбие и постоянную заботу о людях.

Н.А. Дрижд большое внимание уделял улучшению условий труда и быта шахтеров, обустроенности шахтерских городов и поселков. При его активном участии воздвигались целые микрорайоны в Караганде, Шахтинске, Сарани, Абае и во многих шахтерских поселках. Он лично руководил строительством уникальных социальных объектов, в том числе строительством зданий театра музыкальной комедии и гостиницы «Чайка», ставших достопримечательностью шахтерского города.

В свое время он одним из первых организовал подсобное хозяйство на шахте им. Ленина. В дальнейшем он развил этот почин по всему объединению и достиг высоких результатов в решении продовольственной программы. При нем на всех шахтах было организовано горячее питание шахтеров под землей. Под непосредственным управлением объединения «Карагандауголь» находилось несколько совхозов области, большую шефскую помощь шахтеры оказывали сельчанам в строительстве жилья, прокладке дорог, обеспечении электричеством, что значительно улучшало бытовые условия сельчан, которые в свою очередь обеспечивали стабильное снабжение шахтерских семей продуктами питания.

Производственную деятельность Н.А. Дрижд всегда успешно сочетал с научной. Он является автором более 230 научных статей и монографий, им получено 60 авторских свидетельств и 7 патентов на изобретение.

В настоящее время Н.А. Дрижд продолжает трудиться в Карагандинском государственном техническом университете (КарГТУ) в должности профессора кафедры «Разработка месторождений полезных ископаемых», передавая студентам свои обширные научные знания и богатый опыт работы в угольной промышленности.

Многогранная трудовая и общественная деятельность Николая Александровича и его неоценимый вклад в ста-новление и развитие Карагандинского угольного бассейна отмечены целым рядом государственных и ведомственных наград. Среди них: два ордена Ленина, орден Трудового Красного Знамени, орден «Знак Почета», ордена Республики Казахстан «Достык», «Курмет», им. А. Байтурсынова, знак «Шахтерская слава» всех трех степеней и Почетные грамоты. Он дважды Лауреат Государственной премии СССР, Заслуженный горняк Республики Казахстан, Почетный гражданин шахтерских городов Караганды, Сарани и Шахтинска...

\section{Горная общественность Казахстана и России, руководство, директорский корпус и специалисты Угольного департамента АО «АрселорМиттал Темиртау», профсоюз «Коргау», все шахтеры и ветераны Карагандинского угольного бассейна вместе с коллегами по работе в угольной промышленности СССР, ректорат и коллектив КарГТУ, редколлегия и редакция журнала "Уголь» искренне поздравляют Николая Александровича Дрижда со славной датой и желают доброго здоровья, благополучия и активного творческого долголетия!}




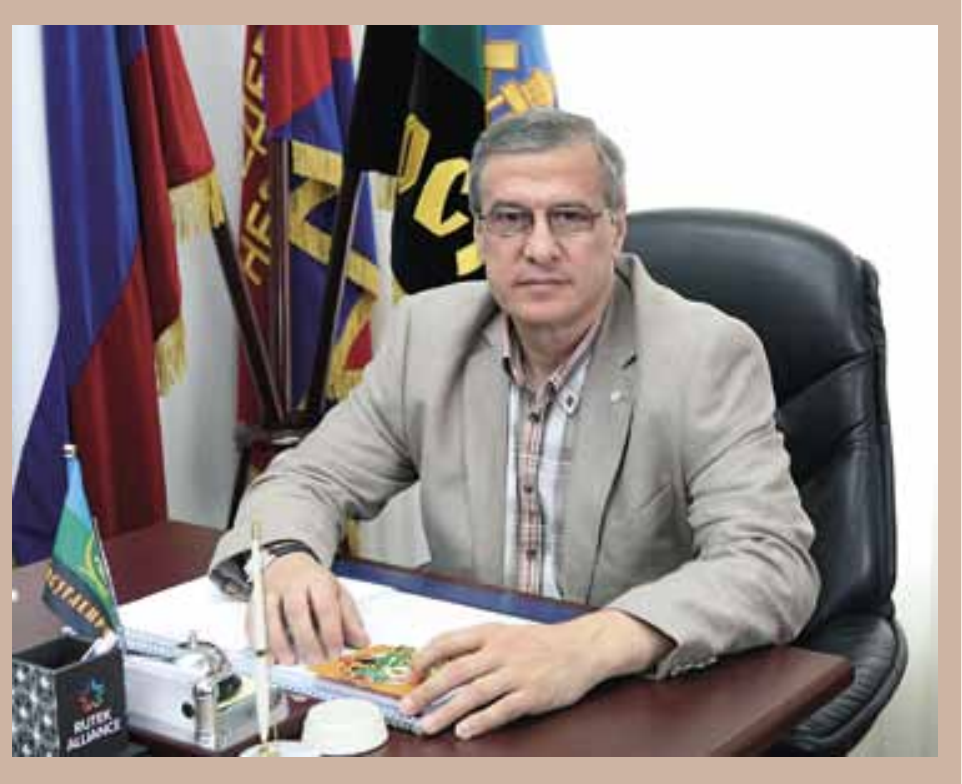

\section{МОХНАЧУК Иван Иванович}

\section{(к 60-летию со дня рождения)}

3 января 2018 г. исполняется 60 лет одному из ярких лидеров иахтерского движения России, председателю Российского независимого профсоюза работников угольной промышленности - Ивану Ивановичу Мохначуку.

Иван Иванович родился в Республике Коми, в приполярной Инте, в шахтерской семье. Трудовой путь он начал на шахте - учеником электрослесаря, электрослесарем подземным. Окончил техникум, получив квалификацию «горный техникэлектромеханик». После службы в армии вернулся в Инту, работал на шахтах - электрослесарем подземным, горным мастером, механиком проходческого и добычного участков. Активно участвовал в шахтерском движении, возглавил забастовки угольщиков Инты. В 1989 г. И.И. Мохначук был избран председателем Интинской ассоциации профорганизаций работников угольной промышленности, начав свой путь в профсоюзах.

Доскональное знание производства, глубокое понимание психологии и чаяний шахтеров, стремление улучшить ихжизнь, помноженные на энергию и выдающиеся организаторские способности, предопределили быстрый и профессиональный рост И.И. Мохначука как профсоюзного лидера.

В 1991 г. недавний интинский шахтер становится заместителем председателя Российского независимого профсоюза работников угольной промышленности, а в 1998 г. его избирают, на альтернативной основе, председателем Росуглепрофа. И вот уже два десятилетия И.И. Мохначук возглавляет самый авторитетный отраслевой профсоюз России.
Все это время каждодневную практику своей работы шахтерский лидер подпитывает теоретическими знаниями. В разные годы он получил два диплома о высшем образовании с присвоением квалификаций «экономист» и «юрист». В Центральном НИИ экономики и научно-технической информации угольной промышленности И.И. Мохначук в 2003 г. успешно защитил кандидатскую диссертацию на тему «Развитие механизма регулирования социально-трудовых отношений в угольной отрасли в условиях рыночной экономики», ему присуждена ученая степень - «кандидат экономических наук».

Грамотно, с учетом социально-экономических реалий в угольной отрасли, председатель Росуглепрофа определяет приоритеты в деятельности организации, нацеливает все ее звенья на сотрудничество с государством и бизнесом, на сохранение социальной стабильности в регионах, имея целью повышение качества жизни шахтеров. В том, что руководство страны считает отрасль ключевой в деле обеспечения экономической безопасности Российской Федерации, есть и заслуга Российского профсоюза угольщиков и лично И.И. Мохначука.

Немало времени председатель Росуглепрофа отдает налаживанию и укреплению международных связей профсоюза. Он член Исполкома Глобального союза IndustriALL, объединяющего 50 миллионов работников в 140 странах мира.

Деятельность председателя, выходящая за рамки системы профсоюзов, помогает в эффективном решении вопросов защиты интересов трудящихся отрасли. И.И. Мохначук являлся членом Общественной Палаты РФ (2008-2016 гг.), возглавляя рабочую группу по совершенствованию трудового законодательства; он является членом общественных советов нескольких министерств и ведомств, членом Российской трехсторонней комиссии по регулированию социально-трудовых отношений, членом Центрального штаба Общероссийского Народного Фронта, а также доверенным лицом Президента Российской Федерации.

Иван Иванович Мохначук пользуется большим уважением в трудовых коллективах и среди коллег по профсоюзной работе. За многолетнюю и активную работу он награжден орденами Дружбы и Почета, медалью ордена «За заслуги перед Отечеством» II степени, другими многочисленными государственными, ведомственными и профсоюзными наградами, является Почетным работником угольной промышленности и Почетным работником топливноэнергетического комплекса, кавалером знака «Шахтерская слава» трех степеней.

\section{Министерство энергетики Российской Федерации,}

горная и научно-техническая общественность, коллеги по работе, редколлегия и редакция журнала «Уголь» от всей души поздравляют Ивана Ивановича с замечательным юбилеем, желают большого человеческого счастья, здоровья и успехов в его нелегком труде на благо России! 


\title{
СМИРНОВ Олег Владимирович
}

\author{
(к 60-летию со дня рождения)
}

14 января 2018 г. исполняется 60 лет горному инженеру, кандидату технических наук, начальнику Управления аэрологической безопасности предприятий АО «СУЭК» Олегу Владимировичу Смирнову.

Работе в угольной отрасли юбиляр посвятил более 40 лет своей жизни, пройдя длинный трудовой путь от горного мастера передовой шахты Донбасса до руководящей должности в крупнейшей угледобывающей компании страны.

Больше десяти лет своей трудовой деятельности Олег Владимирович Смирнов посвятил научной работе в ИГД им. А.А. Скочинского. На его счету множество научных публикаций в различных профильных изданиях, а коллеги по научному цеху высоко ценят производственный опыт Олега Владимировича, который позволяет ему ставить

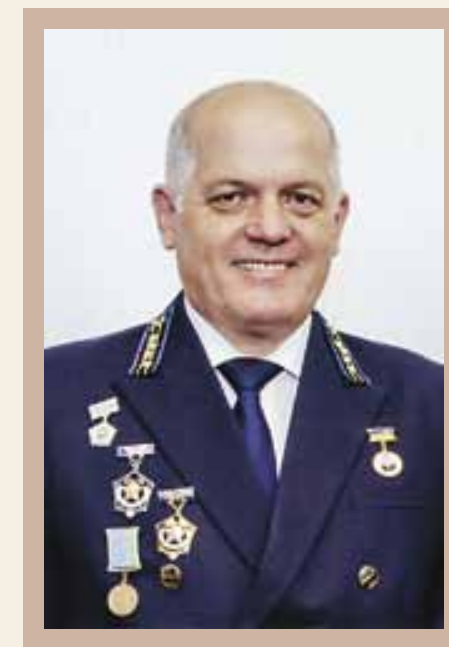

актуальные научные задачи и совместными усилиями успешно решать их, добиваясь полезных практических результатов. В 2004 г. он защитил кандидатскую диссертацию на тему «Повышение безопасности горных работ на основе эффективной вентиляции и предварительной дегазации выемочных участков».

Обеспечение безопасности людей на производстве всегда было для Олега Владимировича первостепенной задачей, и это стремление привело его в Министерство топливной энергетики, где, занимая должность начальника Управления техники безопасности и охраны труда, он участвовал в создании важнейших нормативных документов, регламентирующих вопросы безопасности.

Многолетний практический и научный опыт работы, высокая эрудиция в смежных областях позволили Олегу Владимировичу осуществить ряд сложнейших задач по вне- дрению в угольных шахтах компании $\mathrm{AO}$ «СУЭК» современных мультифункциональных систем безопасности, позволяющих быстро и квалифицированно решать инженерные задачи, касающиеся вопросов вентиляции, дегазации, динамических явлений и предупреждения аварий. Управление аэрологической безопасности предприятий $\mathrm{AO}$ «СУЭК», которое он возглавляет, решает сложнейшие вопросы, связанные с безопасностью при постоянно нарастающих темпах подземной угледобычи и ухудшении горно-геологических условий.

За профессионализм, добросовестный труд и личный вклад в повышение эффективности и безопасности подземного горного производства О.В. Смирнов по достоинству награжден знаками «Шахтерская слава» III и II степеней и нагрудным знаком отличия «СУЭК. Шахтерская доблесть» II степени.

Коллеги по работе, горная научная общественность, редколлегия и редакция журнала «Уголь» от всей души поздравляют Олега Владимировича Смирнова с юбилеем

и желают ему новых профессиональных успехов, крепкого здоровья, счастья и благополучия!

\section{Горнякам Тугнуйского региона вручили государственные награды}

\section{В День Конституиии (12 декабря 2017 г.), в Бурятии состоялось вручение государственныхнаград Российской Фе- дерации тем, кто своим трудом внес вклад в развитие республики. Государ- ственные награды Российской Федера- иии вручили глава Бурятии Алексей Цыденов и главный федеральный инспектор Республики Сергей Ромахин.}

Перед началом церемонии Алексей Цыденов поздравил всех собравшихся с Днем Конституции и обратился с поздравительными словами к награждаемым: «У нас много заслуженных людей, людей, которые своим трудом, своей жизнью показывают, что они достойные люди великой страны. И сегодня часть из этих людей с нами. Мы можем торжественно вручить им награды, подостоинствуоценив их труд и заслуги».

Медали Ордена «За заслуги перед Отечеством» II степени за большой вклад в развитие угольной промышленности

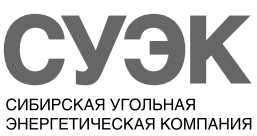

и многолетнюю добросовестную работу вручили работникам AO «Разрез «Тугнуйский»: машинистам экскаватора Анатолию Самбурову и Сергею Матвееву, начальнику участка горных работ Николаю Хохрякову, первому заместителю генерального директора по обогащению ООО «Тугнуйская обогатительная фабрика» Владимиру Добрияну.

Почетного звания «Заслуженный шахтер Российской Федерации» удостоен начальник дробильно-сортировочного участка Тугнуйской обогатительной фабрики Евгений Жидков.

«Тугнуйский угольный разрез - один из самых эффективных в мире, по сравнению с американскими, австралийскими и другими разрезами. Если не ошибаюсь, 8 мировых рекордов производительности побил этот разрез. О нем писали все журналы. И неудивительно, что оттуда столько людей получили государственные награды», - добавил Алексей Цыденов. 


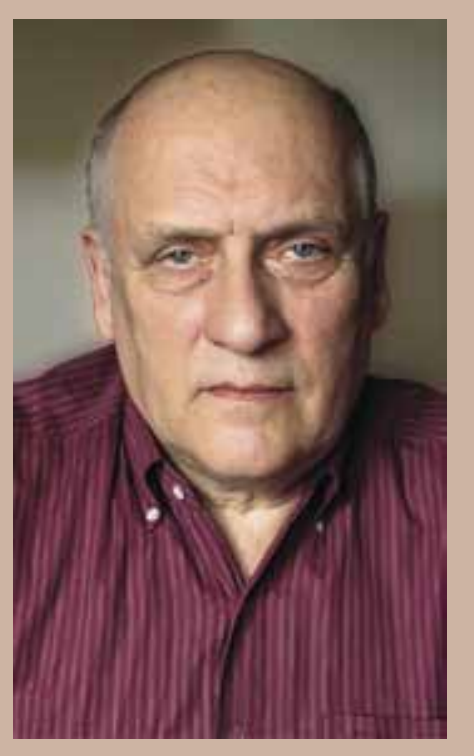

\section{ГРИБИН Юрий Георгиевич}

\section{(к 80-летию со дня рождения)}

24 января 2018 г. исполняется 80 лет со дня рождения и 60 лет инженерной, научной и литературной деятельности горного инженера, доктора экономических наук, профессора, действительного члена Академии горных наук, Почетного работника угольной промышленности и топливноэнергетического комплекса России, члена Московской городской писательской организачии и Литературного фонда России Юрия Георгиевича Грибина.

Юрий Георгиевич родился в г. Владивостоке в семье горного техника Георгия Петровича Грибина и гидролога Галины Владимировны Кузнецовой. Окончив в 1962 г. Московский горный институт по специальности «Разработка месторождений полезных ископаемых», он работал в Норильском горно-металлургическом комбинате им. А.П. Завенягина в качестве взрывника, старшего инженера, мастера опытноисследовательского цеха, а с 1965 г. - в ИГД им. А.А. Скочинского в должности младшего, а затем старшего научного сотрудника.
После окончания аспирантуры он перешел на работу в ЦНИЭИуголь старшим научным сотрудником в лаборатории Нормирования труда. В ЦНИЭИугле Юрий Георгиевич работал заведующим научно-организационным отделом, заведующим научно-исследовательской лабораторией подготовки кадров, с 1985 г. - заведующим научно-исследовательским отделом «Социальных проблем и организации оплаты труда», а в последние годы заведующим научно-исследовательской лабораторией «Экономики и управления персоналом».

После защиты докторской диссертации в ЦНИЭИугле Ю.Г. Грибин долгие годы работал председателем специализированного докторского совета, в котором успешно защитили диссертации более ста специалистов угольной промышленности. Он являлся научным руководителем двадцати аспирантов и соискателей ученой степени, награжден почетной грамотой ВАК СССР за подготовку научных кадров высшей квалификации, успешно трудился экспертом ВАК СССР, членом докторского совета в МГГУ, председателем аттестационной комиссии МГОУ.

Юрий Георгиевич был научным руководителем и ответственным исполнителем научно-исследовательских работ в области совершенствования методологии, практики, информационного обеспечения организации управления и стимулирования труда, изыскания резервов роста производительности труда, социальной защиты работников угольной промышленности. В отрасли до настоящего времени широко используются разработанные при его непосредственном участии Методические рекомендации по регулированию трудовых отношений, организации заработной платы, формированию социальных стандартов сучетом особенностей рыночной экономики, модернизации и реструктуризации угледобывающих предприятий.

Под научным руководством и при непосредственном участии Ю.Г. Грибина созданы методические основы про- ектирования отраслевых соглашений и коллективных договоров, выбора и анализа рациональных форм и систем оплаты труда, разработки системы премирования, стимулирования, прогнозирования развития заработной платы.

Ю.Г. Грибин является автором более двухсот печатных научных трудов, в том числе монографий, книг, брошюр, статей которые широко используются в настоящее время специалистами в отраслях ТЭК при совершенствовании организации, оплаты и стимулирования труда.

Имя профессора Грибина широко известно за рубежом. Он активно участвовал в проведении исследований совместно со специалистами Венгрии, Чехии, Польши, Германии, неоднократно выезжал в зарубежные научные командировки, участвовал в международных конференциях, симпозиумах, семинарах. Имеет научные труды, опубликованные совместно с коллегами из зарубежных угледобывающих стран.

Юрий Георгиевич принимал активное участие в подготовке информационных материалов для угольной промышленности и ТЭК, являлся членом редакционной коллегии информационного сборника «Экономика угольной промышленности», а также сборников научных трудов ЦНИЭИугля.

Ю.Г. Грибин - московский писатель, член Союза писателей и Литературного фонда России, издал двадцать шесть сборников стихов и рассказов. Его произведения лиричны, целомудренны, самобытны и содержательны. За верное служение отечественной литературе Юрий Георгиевич награжден дипломами и медалями Московской городской организации Союза писателей России.

Многогранная трудовая деятельность Юрия Георгиевича Грибина отмечена многочисленными правительственными и ведомственными наградами. Он награжден медалью «За доблестный труд», является кавалером знаков «Трудовая слава» и «Шахтерская слава» трех степеней и др.

Друзья и коллеги по работе, редколлегия и редакция журнала «Уголь» сердечно поздравляют Юрия Георгиевича Грибина со славным юбилеем, желают ему доброго здоровья, долгих лет жизни и дальнейших творческих успехов! 


\section{В Назаровском ГМНУ освоено изготовление}

\section{многотонных запасных частей для шагающих экскаваторов}

ООО «Назаровское горно-монтажное наладочное управление» (Назаровское ГМНУ), сервисное предприятие СУЭК в Красноярском крае, освоило выпуск роликовых кругов для шагающих экскаваторов. Новая продукция предназначена для техники марок ЭШ-20/90 и ЭШ-10/70, широко применяемой для добычи полезных ископаемых открытым способом.

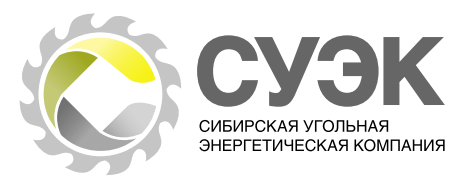

Роликовый круг представляет собой основу опорно-поворотного устройства экскаватора. Это массивное кольцо диаметром до 11 м, в которое вставлены 102 ролика. Вес каждого из роликов достигает 65 кг. Благодаря конструкции осуществляется вращение верхней части горной машины.

Как подчеркивают на предприятии, собранные здесь роликовые круги отличаются особой надежностью. По технологии ролики проходят обязательную закалку в шахтной печи, что позволяет изделию приобрести необходимую твердость и увеличивает как межремонтный интервал, так и общий срок службы конструкции.

С начала 2017 года в Назарово изготовлены уже три роликовых круга. Все конструкции смонтированы на экскаваторах предприятий СУЭК, последняя из них - на Черногорском разрезе в Хакасии. Кроме изготовления специалисты Назаровского ГМНУ выполняют и монтажные работы по замене роликовых кругов на месте эксплуатации машины.

По словам руководителя Назаровского ГМНУ Николая Бережецкого, Назаровское ГМНУ одно из немногих предприятий в стране, которое готово изготовить роликовый круг как для стандартного, так и для кованого рельсового круга, более устойчивого к износам.
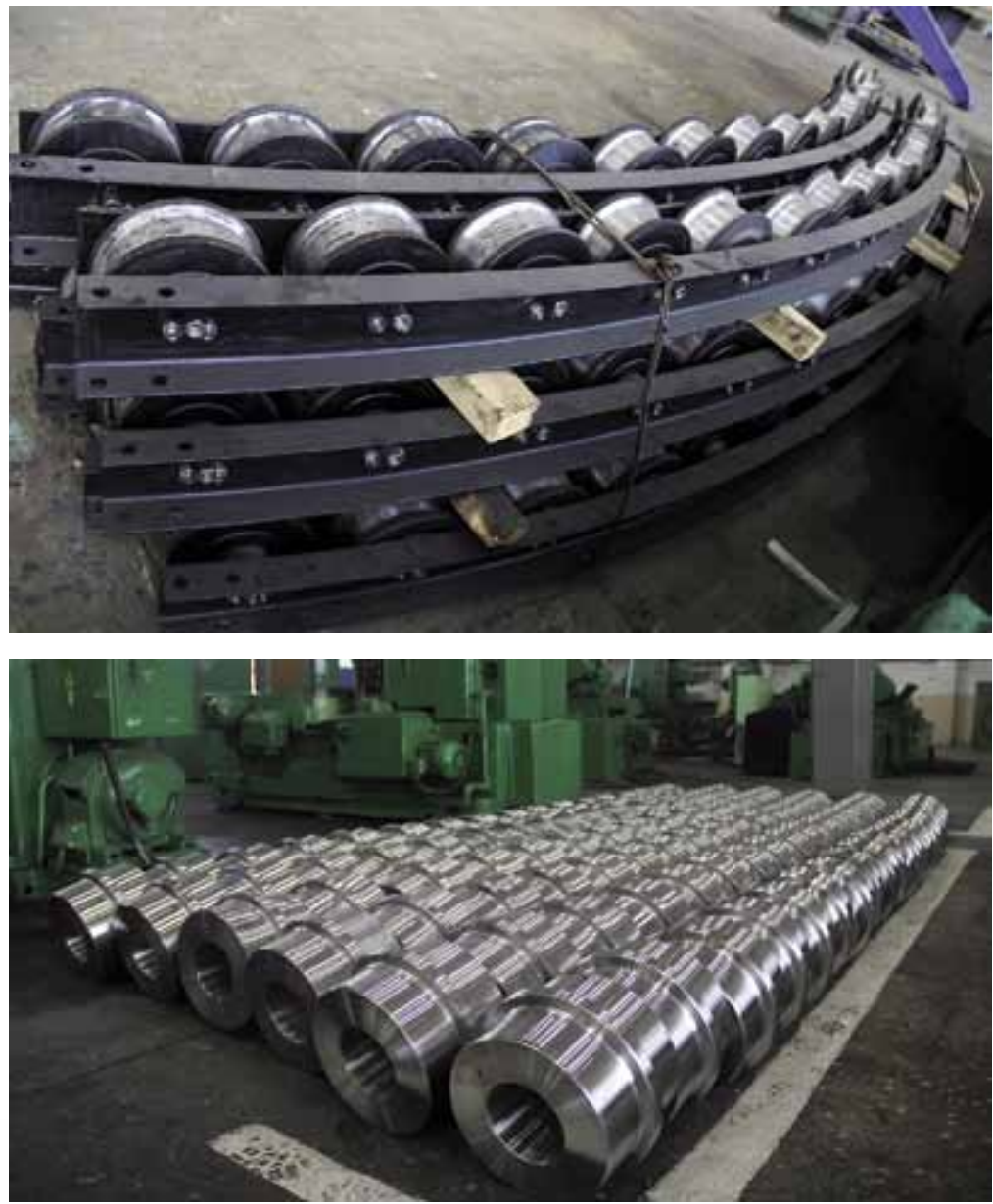

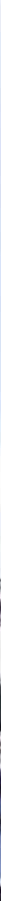


